\title{
RESILIENCE IN SUBURBAN TORONTO
}

\section{suburban renewal in the face of future uncertainties}

\author{
by \\ Adam D. Smith \\ BArchSc, Ryerson University, 2006
}

a design thesis project

presented to Ryerson University

in partial fulfillment of the

requirements for the degree of

Masters of Architecture

in the program of architecture

Toronto, Ontario, Canada, 2010

(C) Adam D. Smith 2010 
author's declaration I hereby declare that I am the sole author of this thesis project. I authorize Ryerson University to lend this thesis project to other institutions or individuals for the purpose of scholarly research.

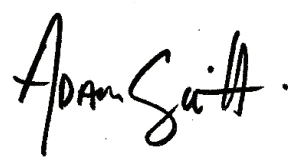

Adam D. Smith

I further authorize Ryerson University to reproduce this thesis project by photocopying or by other means in total part, at the request of other institutions or individuals for the purpose of scholarly research.

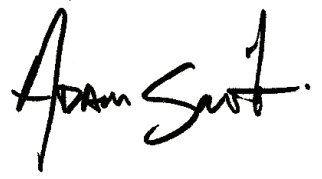

Adam D. Smith 
Resilience in Suburban Toronto: Suburban Renewal in the face of future uncertainties Adam D. Smith

Master of Architecture, 2010

Program of Architecture, Ryerson University

abstract This thesis envisions a new suburban approach based on future uncertainties in environmental,economic and social conditions. The review of responses suggest that resilience building is a viable option for such uncertainties and therefore, focus has been placed on Toronto's suburban housing stock, despite criticism for its fragility and inability to function or change in a future without cheap energy. Although it is often argued that low density neighbourhoods will be unsustainable in a future of environmental uncertainty and that they will not endure the coming crises of peak oil and climate change, Toronto's suburban building stock is ideal for resilience building and will in fact be a vital aspect of Toronto's durability in an uncertain future. This thesis examines different aspects of resilience building in regards to environmental, social and economic uncertainty including: localisation over globalisation, economies of well-being, an ecological systems approach, and rethinking zoning regulations and by-laws. This new vision for the suburbs serves not to replace them with dense urban models, but to maintain and add to suburban qualities while also provoking new ideas for introducing resilience into our built environment. 
acknowledgments thank you Mark Gorgolewski for your guidance and insightful prodding. thank you Mike Ormston Holloway for sharing your experiences. thank you Colin Ripley for your discerning reductionisms. thank you Brackenwood and family for being there. thank you Tom and Joanne Weber for suffering a hermit in your midst. 
dedication to Blythe 
introduction 01

methodology and thesis structure

01 a case for resilient toronto

1.1 the issues

1.1.1 peak oil and climate change 05

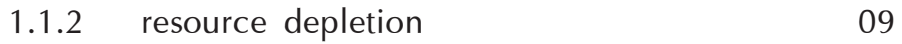

1.1.3 globalization and disconnect from the local 11

1.1.4 the obsolescence of suburbia 13

1.2 the background

1.2.1 suburban toronto context 17

$\begin{array}{lll}1.2 .2 & \text { a history of transition } & 21\end{array}$

$\begin{array}{lll}1.2 .3 & \text { city as ecosystem } 25\end{array}$

1.3 the potential

1.3.1 a market for suburban renewal 35

1.3.2 existing policy models 37

1.3.3 suburban space and architecture 41

02 lessons learned from precedents

$2.1 \quad$ suburban street

2.1.1 mole hill 47

$\begin{array}{lll}2.1 .1 & \text { dutch woonerf } & 49\end{array}$

2.2 suburban space

2.2.1 fabric approach 51

2.2.2 capri court and village homes 53

2.3 suburban change

2.3.1 recalibration of the suburbs 55

2.3.2 parc de la villette 57

2.3.3 learning from Tijuana 59

2.4 principles gleaned 61

03 neighbourhood analysis

3.1 mapping 63

$\begin{array}{lll}3.2 & \text { productivity matrix } & 77\end{array}$

04 the design exploration

4.1 the proposal 93

4.2 a broader context 117

conclusion 149

bibliography 153 


\begin{tabular}{|c|c|c|c|}
\hline \multirow[t]{18}{*}{ list of illustrations } & ix & 0.1 & $\begin{array}{l}\text { suburbs of Toronto as wetland } \\
\text { marsh } \\
\text { drawn by author }\end{array}$ \\
\hline & 5 & 1.1 .1 & $\begin{array}{l}\text { the petroleum interval in its } \\
\text { historic context } \\
\text { source: the Transition Handbook, } \\
\text { Rob Hopkins }\end{array}$ \\
\hline & 6 & 1.1 .2 & $\begin{array}{l}\text { oil \& gas depletion profiles } \\
\text { source: the Transition Handbook, } \\
\text { Rob Hopkins }\end{array}$ \\
\hline & 7 & 1.1 .3 & $\begin{array}{l}\text { petajoules of energy (all fuels } \\
\text { current fossil fuel use } \\
\text { compared with accessible } \\
\text { renewable resources } \\
\text { source: the ZED book, Bill } \\
\text { Dunster }\end{array}$ \\
\hline & 8 & 1.1 .4 & $\begin{array}{l}\text { peak oil \& climate change as } \\
\text { inter-related problem } \\
\text { source: the Transition Handbook, } \\
\text { Rob Hopkins }\end{array}$ \\
\hline & 9 & 1.1 .5 & $\begin{array}{l}\text { collapse } \\
\text { source: amazon.com }\end{array}$ \\
\hline & 10 & 1.1 .6 & $\begin{array}{l}\text { our products grave } \\
\text { source: the ZED book, Bill } \\
\text { Dunster }\end{array}$ \\
\hline & 12 & 1.1 .7 & $\begin{array}{l}\text { consumption and fulfillment } \\
\text { source: the Transition Timeline, } \\
\text { Shaun Chamberlin }\end{array}$ \\
\hline & 13 & 1.1 .8 & $\begin{array}{l}\text { r.i.p. suburbia } \\
\text { source: www.greenrenewable. } \\
\text { wordpress.com }\end{array}$ \\
\hline & 13 & 1.1 .9 & $\begin{array}{l}\text { kunstler's the long emergency } \\
\text { source: www.dir.salon.com }\end{array}$ \\
\hline & 14 & 1.1 .10 & $\begin{array}{l}\text { planning the new suburbia } \\
\text { source: www.olsonplanning.com }\end{array}$ \\
\hline & 15 & 1.1 .11 & $\begin{array}{l}\text { modernistic models for } \\
\text { ordering the city } \\
\text { source: www.strabrecht.nl }\end{array}$ \\
\hline & 15 & 1.1 .12 & $\begin{array}{l}\text { modernistic models for } \\
\text { ordering the city } \\
\text { source: www.ethel-baraona. } \\
\text { tumblr.com }\end{array}$ \\
\hline & 15 & 1.1 .13 & $\begin{array}{l}\text { modernistic models for } \\
\text { ordering the city } \\
\text { source: www.abitare.it }\end{array}$ \\
\hline & 16 & 1.1.14 & $\begin{array}{l}\text { cpuls } \\
\text { source: CPULS, Andre Viljoen }\end{array}$ \\
\hline & 17 & 1.2 .1 & $\begin{array}{l}\text { the growth of Toronto } \\
\text { source: the Toronto guide, } \\
\text { Edward Relph }\end{array}$ \\
\hline & 17 & 1.2 .2 & $\begin{array}{l}\text { welcoming streetcar service, } \\
1925 \\
\text { source: Unplanned suburbs, } \\
\text { Richard Harris }\end{array}$ \\
\hline & 18 & 1.2 .3 & $\begin{array}{l}\text { plan of riverside } \\
\text { source: www.olmstedsociety.org }\end{array}$ \\
\hline
\end{tabular}


1.2.4 transition timeline

source: the Transition Timeline, Shaun Chamberlin

$21 \quad 1.2 .5 \quad 1970$ 's energy crisis source: Sorry, out of gas, Caroline Maniaque

$22 \quad 1.2 .6$

explorations into oil independence source: Sorry, out of gas, Caroline Maniaque

22 1.2.7 Havana, Cuba source: CPULS, Andre Viljoen

$23 \quad 1.2 .8 \quad$ Toronto's blackout source: www.democratandchronicle.com

$24 \quad 1.2 .9 \quad J a c k s o n$ Pollack source: www.picasaweb.com

1.2.10 the non city source: www.atributosurbanos.es

linear v.s. network drawn by author

$27 \quad$ 1.2.12 forefathers of ecological urbanism source: www.wiki pedia.org

succesional sequence source: www.learnline.cdu.edu. au

1.2.14 aerial of Toronto source: The Ontario Ministry of
Natural Resources

$31 \quad$ 1.3.1 the Mayor's tower renewal source: the Mayor's Tower Renewal: an opportunities book

mayor's tower renewal as network

drawn, by author, source: the Mayor's Tower Renewal: an opportunities book

$33 \quad 1.3 .3 \quad$ ravine city

source: Ravine City, Chris

Hardwicke

$33 \quad$ 1.3.4 under-used areas of Toronto feeds city source: Greentopia, RVTR

$34 \quad 1.3 .5 \quad$ architecture 2030 source: Architecture 2030, Ed Mazria

$38 \quad$ 1.3.6 co-op model source: www.cmhc-schl.gc.cam

$40 \quad 1.3 .7 \quad$ streamlined DPS model source: www.mah.gov.on

$42 \quad 1.3 .8 \quad$ stamp out, burn, stack source: www.reburbia.com

$42 \quad 1.3 .9 \quad$ stamp out, burn, stack source: www.reburbia.com
$42 \quad 1.3 .10 \quad$ stamp out, burn, stack source: www.reburbia.com

$43 \quad 1.3 .11$ productive median source: www.reburbia.com

$45 \quad 1.3 .12$ suburbs of Toronto as bread basket drawn by author

$47 \quad 2.1 .1 \quad$ mole hill productivity. source: Canadian Architect Garden city, H. Grdadolnik

$48 \quad 2.1 .2 \quad$ mole hill's living lane source: Canadian Architect Garden city, H. Grdadolnik

$48 \quad 2.1 .3 \quad$ mole hill's residential retrofits Source: Canadian Architect -

$49 \quad 2.1 .4 \quad 1970$ 's dutch woonerf source: Woonerf Revisited, S. Schepel

$49 \quad 2.1 .5 \quad$ Vermeer's Straatje source: www.essentialvermeer. com

$50 \quad 2.1 .6 \quad$ the living street, the living yard source: Woonerf Revisited, S. Schepel

$50 \quad 2.1 .7 \quad$ pedestrian street source: www.clas.ufl.edu

$51 \quad 2.2 .1 \quad$ separations source: Suburban Space, Renee Chow

$52 \quad 2.2 .2$ a comparison between Levittown and Sachs apartments source: Suburban Space, Renee Chow

$52 \quad 2.2 .3 \quad$ claimed and unclaimed, accessed source: Suburban Space, Renee Chow

$53 \quad 2.2 .4 \quad$ village homes source: five steps towards a new suburbia, C. Drukker

$54 \quad 2.2 .5 \quad$ integrated space source: www. www.eslarp. illinois.edu.la

$54 \quad 2.2 .6 \quad$ capri court source: five steps towards a new suburbia, $C$. Drukker

$55 \quad 2.3 .1 \quad$ online resources source: the Green Braid, K. Tanzer

$56 \quad 2.3 .2$ recalibration of the suburbs source: the Green Braid, K. Tanzer

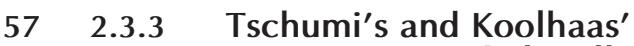
vision for parc de la villette source: www.crisman.scripts. mit.edu. 


\begin{tabular}{|c|c|c|c|c|c|}
\hline 58 & 2.3 .4 & $\begin{array}{l}\text { Koolhaas' layered approach } \\
\text { source: www.theleafaway. } \\
\text { tumblr.com }\end{array}$ & 76 & 3.1 .10 & $\begin{array}{l}\text { urban harvest mapping } \\
\text { for Knob Hill - a layering of } \\
\text { productivity }\end{array}$ \\
\hline 58 & 2.3 .5 & $\begin{array}{l}\text { conceptual skecthes } \\
\text { source: www.facestoplaces. } \\
\text { altervista.orgarchresearch.com }\end{array}$ & & & $\begin{array}{l}\text { drawn by author, source: } \\
\text { Material Neutral Buildings, } \\
\text { Ronald Rovers }\end{array}$ \\
\hline 59 & 2.3 .6 & $\begin{array}{l}\text { Tijuana suburban renewal } \\
\text { source: www.world-architects. } \\
\text { com/estudio }\end{array}$ & 78 & 3.2 .1 & $\begin{array}{l}\text { matrix of potential strategies } \\
\text { drawn by author }\end{array}$ \\
\hline \multirow[t]{2}{*}{59} & \multirow[t]{2}{*}{2.3 .7} & $\begin{array}{l}\text { com/estudio } \\
\text { estudio Teddy Cruz } \\
\text { conceptual models }\end{array}$ & 80 & 3.2 .2 & $\begin{array}{l}\text { matrix of potential strategies - } \\
\text { ecology/yard } \\
\text { drawn by author }\end{array}$ \\
\hline & & $\begin{array}{l}\text { source: www.world-architects. } \\
\text { com/estudio }\end{array}$ & 82 & 3.2 .3 & $\begin{array}{l}\text { matrix of potential strategies - } \\
\text { energy/lane }\end{array}$ \\
\hline \multirow[t]{2}{*}{60} & \multirow[t]{2}{*}{2.3 .8} & estudio Teddy Cruz san diego & & & drawn by author \\
\hline & & $\begin{array}{l}\text { proposal } \\
\text { source: www.world-architects. } \\
\text { com/estudio }\end{array}$ & 84 & 3.2 .4 & $\begin{array}{l}\text { matrix of potential strategies - } \\
\text { food/street } \\
\text { drawn by author }\end{array}$ \\
\hline 60 & 2.3 .9 & $\begin{array}{l}\text { estudio Teddy Cruz san diego } \\
\text { proposal } \\
\text { source: www.world-architects. } \\
\text { com/estudio }\end{array}$ & 86 & 3.2 .5 & $\begin{array}{l}\text { matrix of potential strategies - } \\
\text { water/street } \\
\text { drawn by author }\end{array}$ \\
\hline \multirow[t]{2}{*}{60} & \multirow[t]{2}{*}{2.3 .10} & \multirow{2}{*}{$\begin{array}{l}\text { estudio Teddy Cruz san diego } \\
\text { proposal } \\
\text { source: www.world-architects. } \\
\text { com/estudio }\end{array}$} & 88 & 3.2 .6 & $\begin{array}{l}\text { matrix of potential strategies - } \\
\text { material/house } \\
\text { drawn by author }\end{array}$ \\
\hline & & & 91 & 3.2 .7 & synergistic potential \\
\hline 64 & 3.1 .1 & $\begin{array}{l}\text { walking map of Knob Hill } \\
\text { drawn by author }\end{array}$ & & & drawn by author \\
\hline \multirow[t]{2}{*}{64} & \multirow[t]{2}{*}{3.1 .2} & \multirow{2}{*}{$\begin{array}{l}\text { photo series of Knob Hill } \\
\text { walking exercise } \\
\text { photography by author }\end{array}$} & 93 & 4.1 .1 & $\begin{array}{l}\text { early explorations into } \\
\text { regulatory changes } \\
\text { drawn by author }\end{array}$ \\
\hline & & & 94 & 4.1 .2 & plan of existing Knob Hill \\
\hline \multirow[t]{2}{*}{68} & \multirow[t]{2}{*}{3.1 .3} & \multirow{3}{*}{$\begin{array}{l}\text { Wellington, the kind of } \\
\text { neighbourhood you thought } \\
\text { disappeared a hundred years } \\
\text { ago } \\
\text { source: the American Lawn, } \\
\text { Georges Teyssot } \\
\text { contradiction of the suburbs } \\
\text { drawn by author }\end{array}$} & & & $\begin{array}{l}\text { block } \\
\text { drawn by author }\end{array}$ \\
\hline & & & 94 & 4.1 .3 & $\begin{array}{l}\text { framework for redefining Knob } \\
\text { Hill block } \\
\text { drawn by author }\end{array}$ \\
\hline 68 & 3.1 .4 & & 96 & 4.1 .4 & $\begin{array}{l}\text { woonerf layout (public/private } \\
\text { interface) } \\
\text { drawn by author }\end{array}$ \\
\hline 69 & 3.1 .5 & \multirow{2}{*}{$\begin{array}{l}\text { the formal failure of the } \\
\text { suburbs } \\
\text { drawn by author } \\
\text { land availability in Knob Hill } \\
\text { drawn by author }\end{array}$} & 96 & 4.1 .5 & $\begin{array}{l}\text { street side layout (public) } \\
\text { drawn by author }\end{array}$ \\
\hline 70 & 3.1 .6 & & 96 & 4.1 .6 & $\begin{array}{l}\text { granny flat layout (private) } \\
\text { by author }\end{array}$ \\
\hline 72 & 3.1 .7 & $\begin{array}{l}\text { walking distances of Knob Hill } \\
\text { drawn by author }\end{array}$ & 96 & 4.1.7 & $\begin{array}{l}\text { house additions layout } \\
\text { (private) } \\
\text { drawn by author }\end{array}$ \\
\hline \multirow[t]{2}{*}{74} & \multirow[t]{2}{*}{3.1 .8} & \multirow{5}{*}{$\begin{array}{l}\text { urban harvest mapping for } \\
\text { Knob Hill - current condition } \\
\text { drawn by author, source: } \\
\text { Material Neutral Buildings, } \\
\text { Ronald Rovers } \\
\text { urban harvest mapping for } \\
\text { Knob Hill -a marriage between } \\
\text { lower and higher densities } \\
\text { drawn by author, source: } \\
\text { Material Neutral Buildings, } \\
\text { Ronald Rovers }\end{array}$} & 98 & 4.1 .8 & $\begin{array}{l}25 \% \text { of maximum buildable } \\
\text { area } \\
\text { by author }\end{array}$ \\
\hline & & & 100 & 4.1 .9 & $50 \%$ of maximum buildable \\
\hline \multirow[t]{3}{*}{76} & \multirow[t]{3}{*}{3.1 .9} & & & & $\begin{array}{l}\text { area } \\
\text { drawn by author }\end{array}$ \\
\hline & & & 102 & 4.1 .10 & $\begin{array}{l}100 \% \text { of maximum buildable } \\
\text { area } \\
\text { drawn by author }\end{array}$ \\
\hline & & & 104 & 4.1.11 & $\begin{array}{l}\text { shared entranceways } \\
\text { drawn by author }\end{array}$ \\
\hline
\end{tabular}


106

4.1.12 overhead connections

drawn by author

$108 \quad 4.1 .13$ building linkages

drawn by author

$110 \quad 4.1 .14$ shared landscapes

drawn by author

1124.1 .15 private outdoor space drawn by author

1144.1 .16 incremental changes in suburban Toronto drawn by author

118 4.2.1 elements of the wetland marsh drawn by author

120 4.2.2 wetland marsh narrative drawn by author

122 4.2.3 wetland marsh located in Knob Hill drawn by author

123 4.2.4 Toronto ravine system drawn by author, source: CanMap RouteLogistics 2009.4, DMTI Spatial Inc.

$124 \quad 4.2 .5 \quad$ elements of the urban forest drawn by author

$126 \quad$ 4.2.6 urban forest narrative drawn by author

128 4.2.7 urban forest located in Knob Hill drawn by author

$129 \quad 4.2 .8 \quad$ Toronto greenspace drawn by author, source: CanMap RouteLogistics 2009.4, DMTI Spatial Inc.

$130 \quad$ 4.2.9 elements of the bread basket drawn by author

132 4.2.10 bread basket narrative drawn by author

134 4.2.11 bread basket located in Knob Hill drawn by author

135 4.2.12 Toronto wards and schools drawn by author, source: CanMap RouteLogistics 2009.4, DMTI Spatial Inc.

1364.2 .13 elements of the solar collector drawn by author

138 4.2.14 solar collector narrative drawn by author

140 4.2.15 solar collector located in Knob Hill drawn by author

141 4.2.16 Toronto hydro corridors drawn by author, source: CanMap RouteLogistics 2009.4, DMTI Spatial Inc.
142 4.2.17 elements of the shoe cobbler drawn by author

144 4.2.18 shoe cobbler narrative drawn by author

146 4.2.19 shoe cobbler located in Knob Hill drawn by author

147 4.2.20 Toronto transportation system by author

147 4.2.20 Toronto transportation system drawn by author, source: CanMap RouteLogistics 2009.4, DMTI Spatial Inc. 


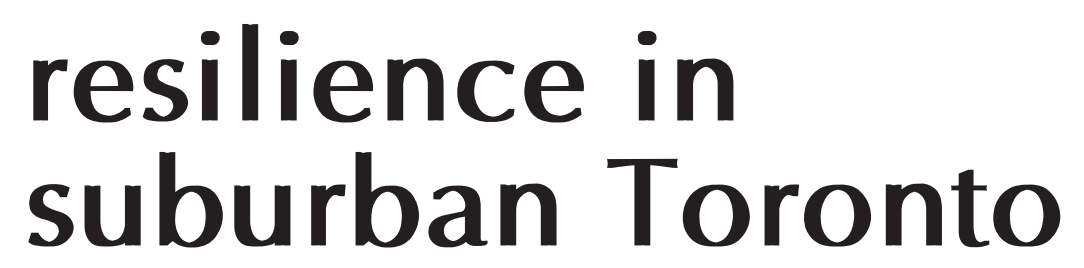
suburban renewal in the face of future uncertainties 


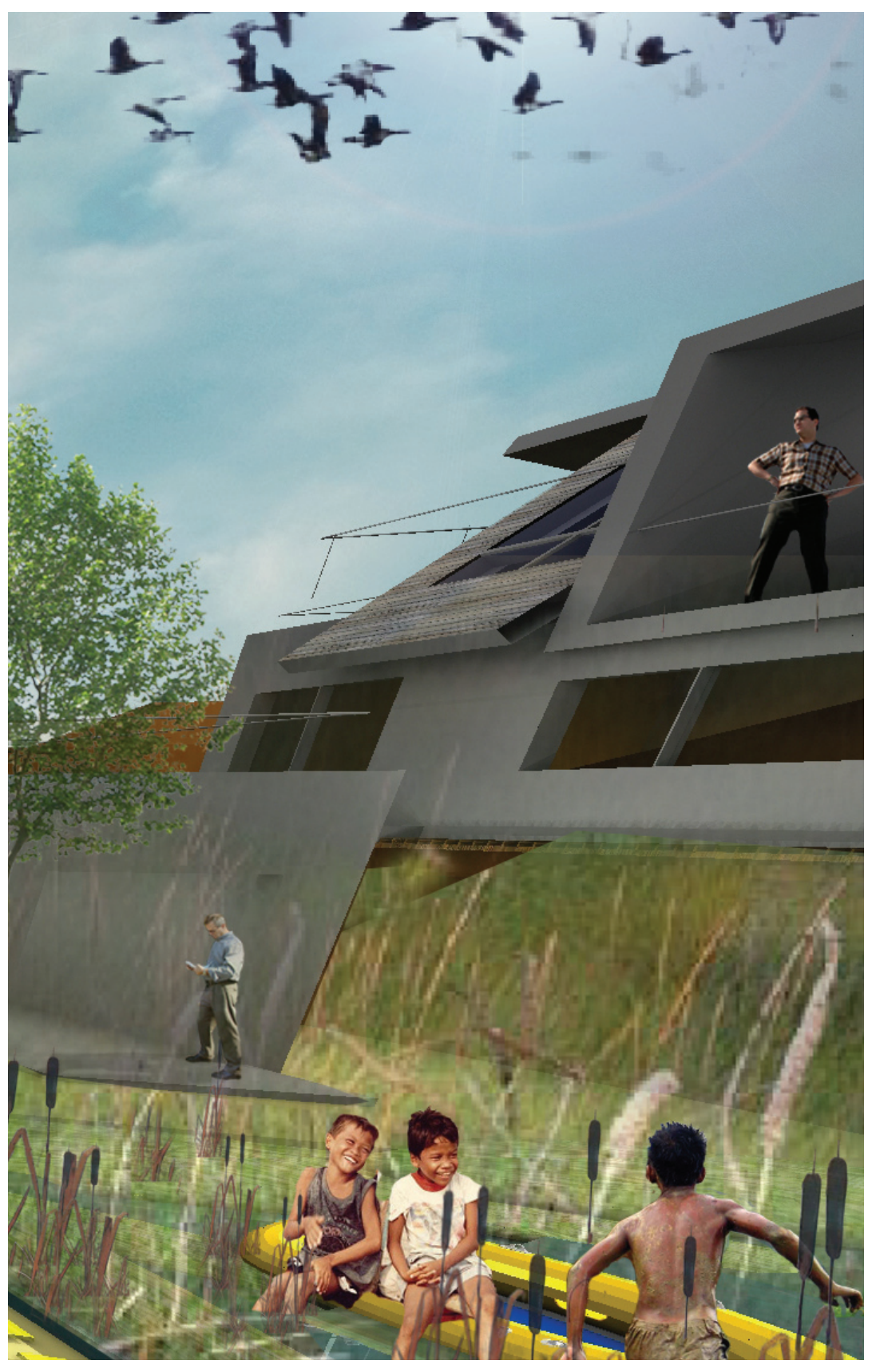

fig. 0.1 suburbs of toronto as XIV wetland marsh 
Our culture is underpinned by various stories, cultural myths that we all take for granted: that the future will be wealthier than the present, that economic growth can continue indefinitely, that we have become such an individualistic society that any common goals are unthinkable, that possessions can make you happy, and that economic globalisation is an inevitable process to which we have all given our consent. We need new stories that paint new possibilities, that reposition where we see ourselves in relation to the world around us, that entice us to view the changes ahead with anticipation for the possibilities they hold, and that will, ultimately, give us the strength to emerge at the other end into a new, but more nourishing, world.

Rebuilding local agriculture and food production, localising energy production, rethinking healthcare, rediscovering local building materials in the context of zero energy building, rethinking how we manage waste, all build resilience and offer the potential of an extraordinary renaissance - economic, cultural and spiritual. (Hopkins, 2008)

introduction Durability is defined by Webster's dictionary as the ability to exist for an extended period of time without significant deterioration; i.e. long lasting, resistant to decay and enduring. It is a word typically used to describe material decay but can equally convey the understanding of prolonged well-being in our communities, neighbourhoods, and cities. Just as the durability of a brick exposed to weather depends on factors such as its resistance to water erosion and corrosion, the durability of a city depends on its ability to endure disturbances caused by external forces. In light of looming climatic uncertainties, oil and resource depletions, and the disturbances of local markets due to globalization, our cities are not durable to such forces and are predisposed to systemic failure. To circumvent failure, city thinking must adopt measures (socially, politically, ecologically, and economically) that provide durability over fragility; measures that 
begin to propose ways to respond and adapt to a rapidly fluctuating and unpredictable future. Although there are many aspects of the human project that could benefit from such contemplation, for the purposes of this thesis, an analysis will focus on the physical city, Toronto, and even more specifically the suburban fabric that defines most of Toronto's built environment. Although it is often argued that low density housing will be unsustainable in a future of social,political, ecological, and economic uncertainty, Toronto's existing suburban building stock is ideal for resilience building and will in fact be a vital aspect of the city's durability in an uncertain future. This thesis envisions a new suburban approach based on future uncertainties in environmental, economic and social conditions. This new vision for the suburbs serves not to replace them with urbanity, but to maintain and add to suburban qualities while also provoking new ideas for introducing resilience into our built environment. Before examining Toronto's suburban building stock and condition, the methodology for the research undertaken is explained.

methodology and thesis structure This thesis has been subdivided into four sections, each providing the argument and the research to strengthen and support a design proposal for a new vision for Toronto's suburban inheritance. The first section, a case for resilient Toronto, presents the problems facing Toronto's suburban neighbourhoods in the face of peak oil, climate change, resource depletion, a disconnect from the local, and the obsolescence of suburbia. It goes on to examine Toronto's suburban context, and looks at the history of transitioning out of crisis through the concepts of city as ecosystem and resilience building. Section one ends by looking at the potential market for suburban renewal, the potential policies that may aid such a renewal, and the potential role of the architect in redefining Toronto's suburban inheritance. Section one focuses on literature reviews and presents current thinking on the subjects of resilience and suburban renewal.

Section two, learning from precedents, presents a number of examples of resilience building explorations in an attempt to learn from previous design work, both built and un-built, and to inform the design proposal of the Thesis Project. A lessons gleaned portion summarizes the 
principles learned from these precedent studies.

The third section of the thesis, neighbourhood analysis, documents a series of mapping exercises that explore one of Toronto's eastside suburban neighbourhoods, Knob Hill. The mapping exercises focus on the vulnerability of this particular neighbourhood, illustrating its inability to provide employment and healthy food within walking distance, the land available for resilience building and, at a finer scale, the potential for resilience building at the scale of the street,dwelling, yard, and lane.

Section four, the design exploration, documents the explorations undertaken including the proposition of new parameters and programmatic considerations that would allow flexibility and changes to occur over time, and a set of five typologies that are likely to emerge in light of the research presented. A broader context section illustrates the scale of applicability to the city of Toronto as a whole. 


\section{1 a case for resilient Toronto}




\section{1 the issues}

\subsection{1 peak oil and climate change Climate change and carbon} reductions have been on the table for a number of years, and while the argument for cutting back on our carbon emissions is receiving much attention, the shift to lower carbon footprints has been slow and some would argue non existent. Peak oil has also slowly been entering the sustainability discussion and is increasingly becoming a larger and larger blip on the radar. Rob Hopkins, a forerunner on the issue of peak oil and author of The Transition Handbook: from oil dependency to local resilience (2008), concedes to the urgency of climate change but believes that the peak oil dilemma has much more potency as a catalyst for change. Yes, most would agree that we should not sully the place that we live (Earth) but, according to Hopkins, climate change often leads to a moral imperative that we should change our ways, whereas peak oil leads to the conclusion that we will be forced to change. Richard Heinberg, a peak oil educator and author, explains that at the most superficial level, we could say that climate change is an end-of-tailpipe problem, while peak oil is an into-fuel-tank problem (ibid). Both Heinburg and Hopkins use ASPO's Oil and Gas Production Profiles (fig. 1.1.2) to indicate that we are currently riding the peak and will soon begin the decline of fig. 1.1.1 the petroleum interval in its historic context The presence of petroleum has been short, but has had tremendous impacts on our sociological, cultural, and technological systems.

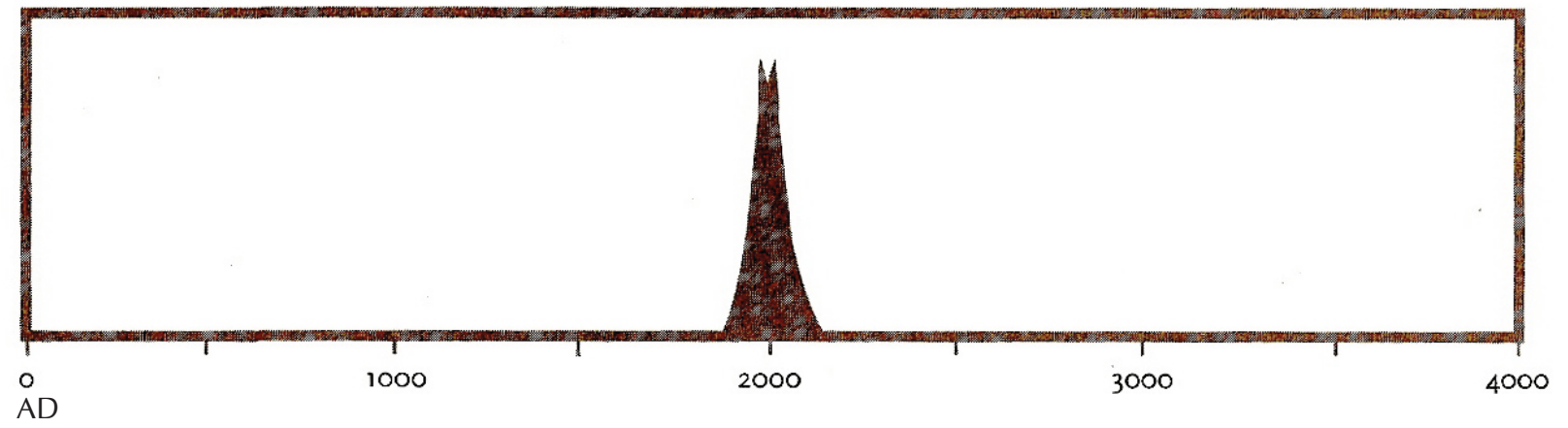




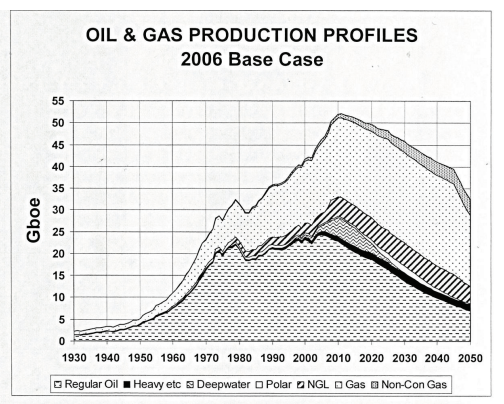

fig. 1.1.2 oil \& gas depletion profiles Many believe oil and gas extraction has peaked or will peak in the next decade. oil production. Once the thought of oil depletion enters the scene, oils presence in almost every aspect of modern life is revealed and our fragile dependence on this limited crude resource seems unwise. From our food supply to the clothes on our backs, oil is responsible for nearly all the luxuries many take for granted. As Hopkins points out:

Aspirins, sticky tape, trainer shoes, lycra socks, glue, paints, varnish, foam mattresses, carpets, nylon, polyester, CDs, DVDs, plastic bottles, contact lenses, hair gel, brushes, toothbrushes, rubber gloves, washing-up bowls, electric sockets, plugs, shoe polish, furniture wax, computers ... loft insulation, PVC windows, shopping bags, lipstick... and that's just some of the things made directly from oil, not those that needed fossil fuels and the energy they consume in their manufacture (which is pretty much everything). (ibid)

Rubin, an economist that shares some of Hopkins' views, believes the world will become a smaller place as globalization disintegrates with the absence of cheap oil. Despite his heralded position on the subject, he has been criticized in Macleans' Energy Shock and Oil Myths (2009) for being a doomsayer and an alarmist. Tertzakian, the chief economist for ARC financial corp., does not deny that peak oil will change our economies, but suggests that it may in fact be beneficial to our society by cutting back on the ailments and bad habits caused by cheap and abundant energy, with obesity being the most obvious example (Campbell, 2009). This aligns with some of the thinking of the transition movement (founded by Rob Hopkins) who's members are often found focusing their intentions by stating that a world without cheap energy may be preferable to the world we live in today (Hopkins, 2008). It is a decidedly optimistic view of a coming energy crisis, but certainly sheds light on a number of the failings that our modern day society could attribute to cheap energy - wastefulness, consumerism, physical ailments, the gap between the rich and the poor - to name a few.

Ultimately, peak oil cannot be addressed in isolation, as Shaun Chamberlin, the author of Transition Timeline (2009) alludes to. Chamberlin argues that a resolution which addresses both climate change and peak oil is needed, as both are threats to the durability of our existence (Chamberlin, 2009). Chamberlin believes that in 
addition to transitioning into a post peak oil future we will also need carbon sequestering or radiation blocking measures. Examples of such measures include anthropogenic carbon sinks (otherwise known as synthetic trees) or reflective mirrors placed between the earth and the sun. Chamberlin arguably notes that such hi-tech solutions will inevitably be energy intensive at best and, in an age of oil scarcity, will not be implementable. Alternatively, he argues for a restoration and preservation of our forests (the most natural and affordable carbon sink) and an alternative approach to agriculture, such as permaculture a radical design science that seeks to mimic and work with natural processes or, as it is otherwise known, the science of maximizing beneficial relationships (Viljoen, 2005). The idea of designing productive environments that sequester carbon from our atmosphere and produce food demonstrates how peak oil and climate change as conjoined problems lead to holistic and synergistic solutions (fig. 1.1.4). fig. 1.1.3 petajoules of energy (all fuels) current fossil fuel use compared with accessible renewable resources The expected total energy output from renewable resources such as sun, wind, hydro and geothermal will not be able to meet the demand that is currently met with fossil fuel combustion.

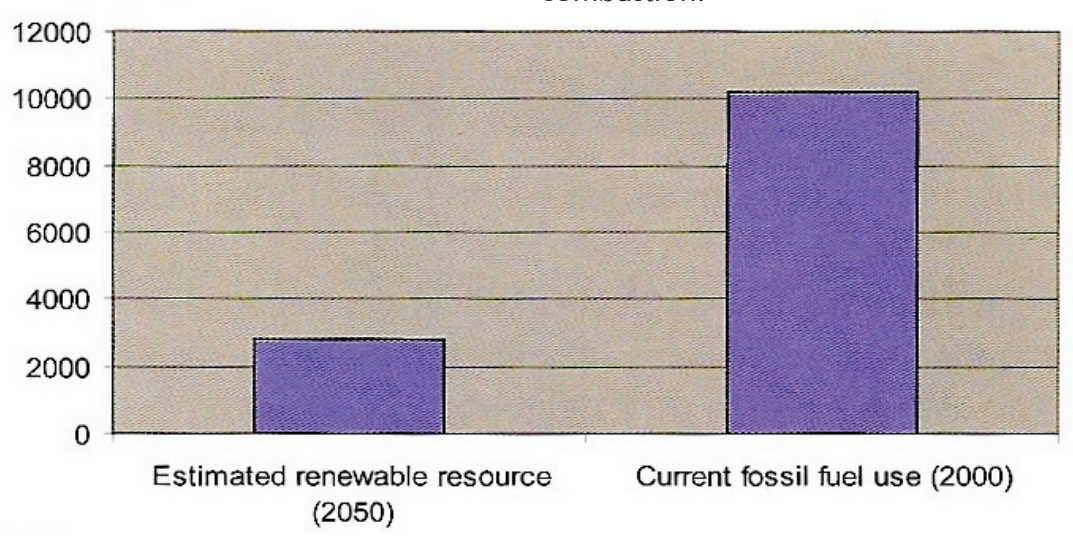




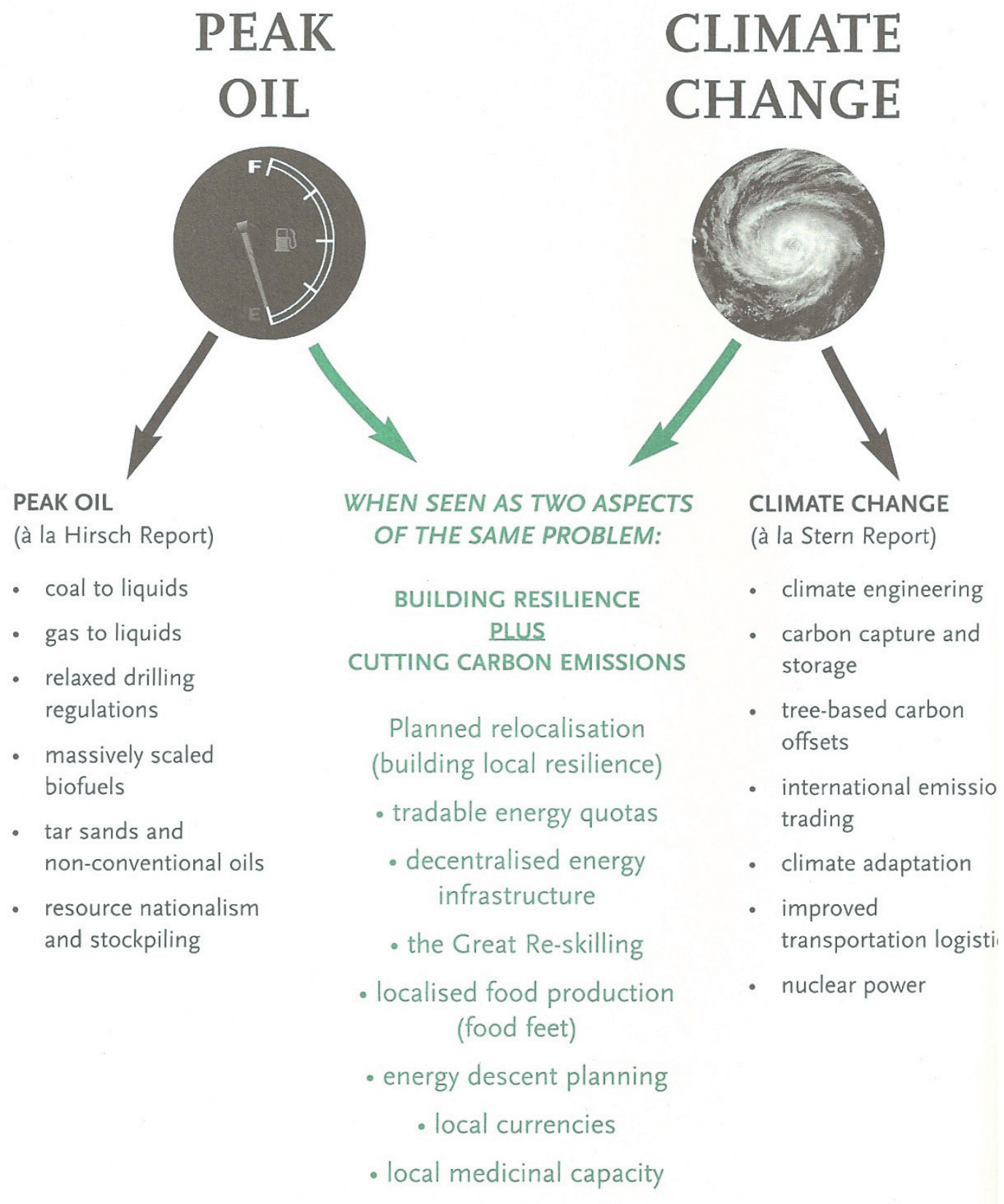




\subsection{2 resource depletion Peak oil is another chapter of the} resource depletion story. Throughout human history we have witnessed civilizations drain themselves of the very resources that they needed for their survival often leading to, as Jared Diamond covers in his work Collapse (2004), the destruction and extinction of entire civilizations (e.g. the Polynesians of Easter Island, the Ancient Romans, the Mayans and the Aztecs - fig 1.1.5). With our modern, industrialized society we have witnessed the usurpation of fresh water, fish stock, healthy soils, forest stands, clean air, raw metals, and the destruction of ecosystems, wildlife and natural systems. Oil, a major resource for modern society, is now recognized as finite, but it is one depleting resource that modern society can live without.

William McDonough and Michael Braungart give a useful overview of the treatment of resources in their book Cradle to cradle: Remaking the way we make things (2002). They demonstrate how we have treated industrial processes as a linear in one end, out the other function, with waste or by-products assumed as inevitable. From the industrial revolution to the last quarter of the $20^{\text {th }}$ century, these by-products were thought of as acceptable. With resource depletion and the accumulation of wastes in our landfills, rivers, atmosphere and oceans we've seen that this was a rather short sighted paradigm and that there are limits to how much we can take from the Earth and how much we can squander. An excerpt from Cradle to Cradle illustrates the general wastefulness of our society and begins to dismantle the assumptions that our current cradle-to-grave worldviews are based on:

\section{opposite}

fig. 1.1.4 peak oil \& climate change as inter-related problems Rob Hopkins argues for the consideration of peak oil and climate change as fundamentally connected problems.

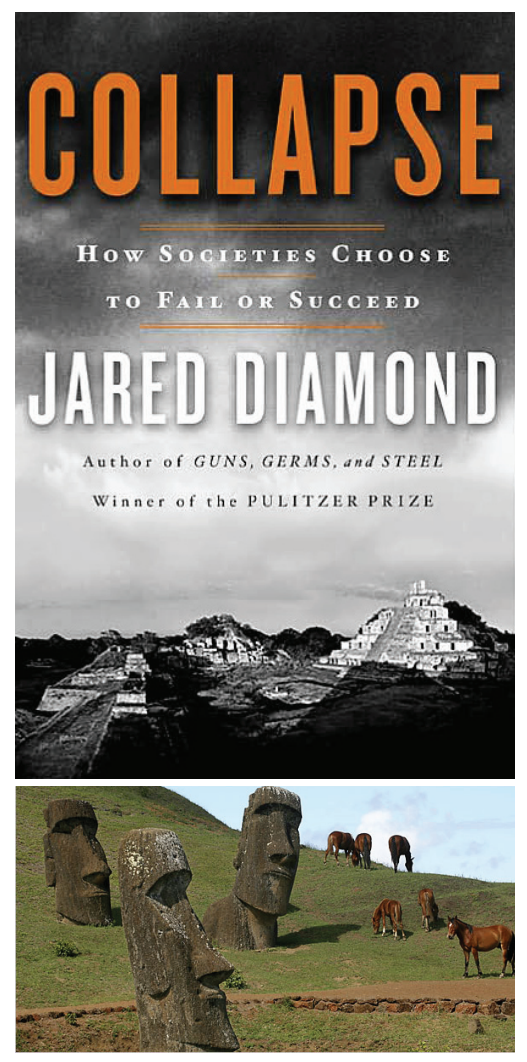

fig. 1.1.5 collapse Jared Diamond demonstrates how humans have repeated depleted themselves of the very resources they needed for their survival. Are we on a similar course? 


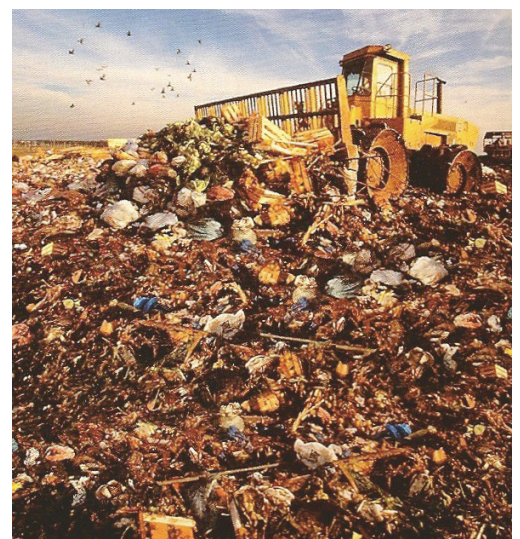

fig. 1.1.6 our products grave Landfills such as the one shown are sites that very few people have seen or are aware of.
Most of the products [found in landfills] were made from valuable materials that required effort and expense to extract and make, billions of dollars worth of material assets. The biodegradable materials such as food matter and paper actually have value too - they could decompose and return biological nutrients to the soil. Unfortunately, all of these things are heaped in a landfill, where their value is wasted. They are the ultimate products of an industrial system that is designed on a linear, one-way cradle-to-grave model. Resources are extracted, shaped into products, sold, and eventually disposed of in a 'grave' of some kind, usually a landfill or incinerator. (McDonough, 2002)

Examples of our wastefulness and the inefficiencies of our cradleto-grave society seem endless. According to some accounts, more than $90 \%$ of materials extracted to produce durable goods in the United States become waste almost immediately (ibid). In The story of stuff, Annie Leonard explains that each American produces 4.5lbs of garbage/day (2 times what we disposed of 30 years ago) and that only 1 percent of products we purchase are still in use after 6 months of leaving the store shelves. In other words 99 percent of the stuff we harvest, mine, process, and transport goes to landfills within 6 months (Leonard,2007). It is estimated that we will require between 3 and 5 times the amount of resources available on Earth to meet the requirements of 6 billion humans living as North Americans (ibid). Much of this waste is the result of modern economies that are based on the concept of continuous growth; the notion that no amount of consumption is enough; and that we must continue to consume increasing amounts for economies to grow and for the North American standard of living to be sustained. How is this possible in a world of finite resources? 


\subsection{3 globalization and a disconnect from the local All of} this stuff that Annie Lennox is deposing in her Story of Stuff is part and parcel of a modern economic system that has long tailored to global markets and the Global Village. Economics based on the hyper-connected network that is the Global Village have led to many improvements and advancements in civilization but have also acted as an obstruction for many initiatives seeking to create local resilience (McKibben, 2007). Those of us in the developed nations are able to glean from such markets affordable food and medicine, a mixture of cultures and technological innovations that have rapidly advanced our ways of life. We also have access to a series of extravagances and luxuries that have been proven to lead to a decrease in our sense of well-being (fig. 1.1.7). In addition to a number of works studying the effects of the accumulation of wealth on our well-being, Mark Anielski's article Are we happy yet? (2009) posits that material wealth does not translate into what most people, he argues, ultimately long for: enduring happiness.

Aside from the accumulation of material goods and the resultant decrease in well-being, globalization has led to other undesirable outcomes such as cultural erasure, the lack of vernacular, a driving out of local markets and a drying up of local products and therefore local economies. Bill McKibben, author of Deep Economy (2007), believes that we need to seek prosperity through local initiatives that encourage local production of food, energy, medicine, culture, entertainment and, of course, the economies that come with them. McKibben outlines why more is no longer associated with better and that we must move beyond growth as a paramount economic ideal (McKibben, 2007). Deep Economy looks at several ways to stimulate
Thomas Homer Dixon in a resilient system, individual nodes like people,companies,communities and even whole countries are able to draw on support and resources from elsewhere, but theyre also self-sufficient enough to provide for their essential needs in an emergency. Yet in our drive to hyper-connect and globalise all the worlds economic and technological networks, weve forgotten the last half of this injunction. (HomerDixon, 2009) 
fig. 1.1.7 consumption and fulfillment There is a point where our fulfillment decreases with increasing consumption. It seems that our ongoing quest for more is leading to overall unhappiness. prosperity through local bearings including cities, suburbs and regions that produce more of their own needs. While globalization strives for greater and greater connections in the global village, it has only been able to do so at the cost of the local village (McKibben, 2007). Accounts of international corporations creating disconnected local environments are abundant. Hopkins, in his call for localization in the Transition Handbook (2008), wholeheartedly agrees that local economies are essential to resilient societies. Although localization movements are gaining in popularity, it is difficult to access local products, since small scale local companies are often competing with cheaper alternatives from global markets and international corporations. The crux of the matter is that unless niches are found and exploited, local entrepreneurs will be out-competed and eventually run out of town by out-of-towners (McKibben, 2007).

Michael Shuman in Going Local (1998) adds to the discussion by stating it is easy to dismiss the principle of self-reliance by pointing to many complex products that communities cannot manufacture on their own. The goal of a self-reliant community, however, is not to create a Robinson Crusoe economy in which no resources, people or goods enter or leave. A self-reliant community simply should seek to increase control over its own economy as far as is practical. (Shuman, 1998)

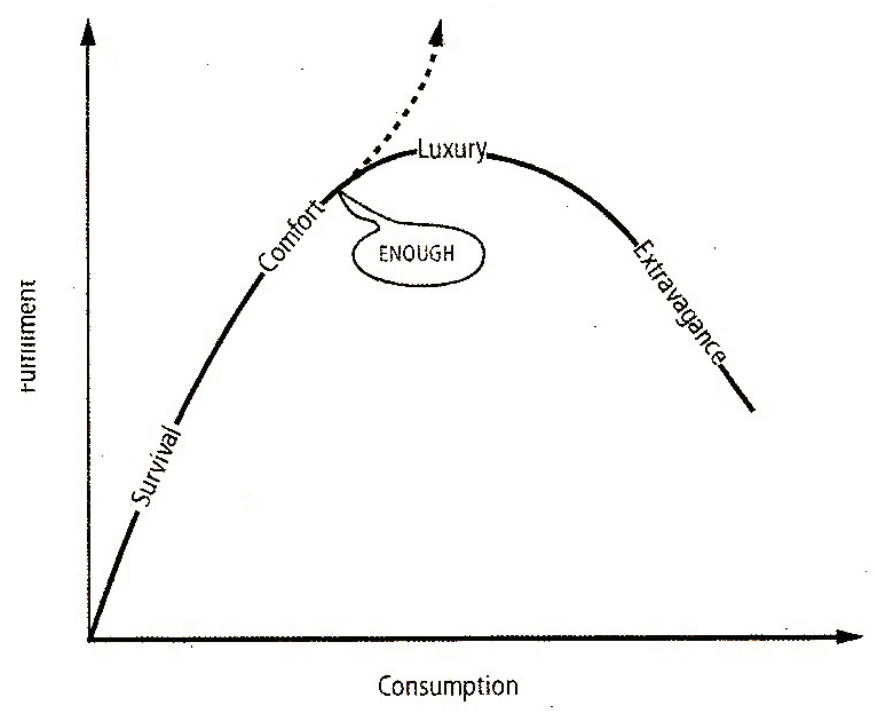


1.1.4 the obsolescence of suburbia Although the ramifications of resource depletion, oil scarcity, and the lack of locality are broadly applicable to all aspects of the human project, they are of particular importance when discussing the majority of North American housing - suburbia. Suburbia is well known for it's dependencies on the car, and therefore on cheap energy. It is also criticized by many as a place lacking any form of self-sufficiency, local culture/character, walkability, productivity, community, or economy. The suburbs clearly began as a middle ground between the city and the country, but have more accurately become the bedrooms of the city due to their general isolation from any form of employment, entertainment, productivity, or economic activity. Many, including James Howard Kunstler in The Long Emergency (2005), adamantly call for an abandonment of suburbia due to its foreseeable obsolescence and its incompetence in a post peak-oil future (figs. 1.1.8, 1.1.9). Granted, much of the critics of suburbia place their judgements as a means of protesting the continuation of suburban sprawl, their arguments nonetheless imply that existing suburban developments are bound for desertion. Kunstler is explicit when he says the suburbs will become a devalued agglomeration of enclaves and slums - salvage yards at best (ibid). In light of resource depletion and of rising energy costs, it would seem wise to consider any existing development as a valuable asset and, like David Holmgren says in his permacultural lectures, we should seek to turn our problems into solutions (Holmgren, 2002).

Toronto's suburbs are the direct result of a series of regulations, policies, by-laws and building codes that have inevitably allowed for nothing other than the current built pattern that we see: dispersed infrastructures, miles of tarmac, dependencies on vehicular travel, separation of uses
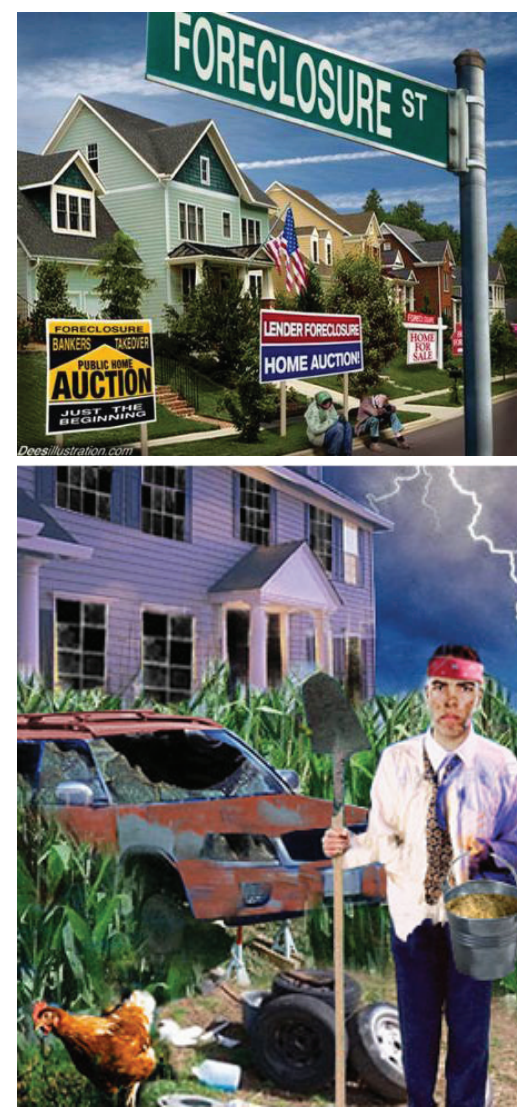

fig. 1.1.8 r.i.p. suburbia above

fig. 1.1.9 Kunstler's the long emergency Kunstler and other theorists believe the suburbs will be deserted slums, with mass populations fleeing to city centers to escape the suburbs. 

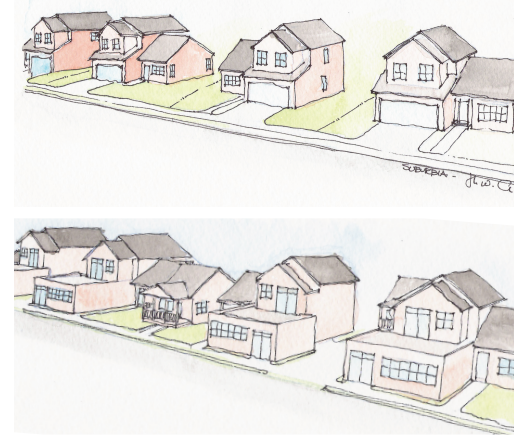

fig. 1.1.10 planning the new suburbia Avi Friedman makes compelling arguements for the conversion of existing suburban neighbourhoods through changes to zoning ordinances. and an isolation of each house and each neighbourhood from any adjacent context. Avi Friedman, an advocate for flexible housing, believes that the lack of housing options is a serious threat to the suburb's sense of community, and that suburbs that offer only one type of housing cannot readily accommodate changes in the lives of its residents (Friedman, 2005). Friedman goes on to show in his work Planning the New Suburbia (2005) that zoning ordinances enacted decades ago - which, for example, demand extremely low densities, restrict the definition of single-family, and make no provisions for working at home - will prevent former bedroom communities from successfully meeting the demands of its future residents (fig. 1.1.10). These regulations must be addressed in order to create a more adaptable suburb (ibid). Chris Duerksen explains in the article Saving the World through Zoning (2008) that we need zoning regulations that take the best from all the current zoning regulations to form a sustainable zoning model that will work to remove obstacles and create incentives for neighbourhoods and communities to enact changes in their surroundings.

Although Toronto's policy makers are exploring innovative zoning ordinances, such as the Development Permit System (see page 38), there remain tremendous hurdles when trying to enact change in Toronto. Despite ample interest to do so, residents of Toronto are not permitted to keep chickens in their back, front or side yards and community composting areas are strictly forbidden (as was seen during Toronto's garbage strike of 2009). Likewise, beekeeping is prohibited in many of the townships surrounding the GTA. Whereas changes to the buildings, streets, and yards might seem like insurmountable feats in the face of today's zoning ordinances, beekeeping and chicken pens are simple, tangible implementations that could add to the resilience of the city immediately. If the suburbs are to re-create themselves into places of productivity and local economies, zoning ordinances must be reconsidered. Toronto's neighbourhoods must be allowed to make the changes that need to be made in order to build resilience against unforeseeable challenges that may arise. Otherwise, communities may well begin to make necessary changes regardless of the stiffness and inflexibility in zoning regulations.

One of the things a lot of the urban planners miss is that they assume that any 
future framework will be driven by public policy and forward planning and design. Whereas, given the speed with which we are approaching this energydescent world, and the paucity of any serious consideration of planning or even awareness of it, we have to take as part of the equation that the adaptive strategies will not happen by some big, sensible, long range planning approach, but will happen organically and incrementally by people just doing things in response to immediate conditions. (Fenderson, 2004)

The process of transition will likely occur with or without city approval; it could be a chaotic process, occurring ad hoc and in disregard of city by-laws or, through governmental involvement, could be coordinated under the rubric of public safety, regulatory instrumentation, and managed change.

A critique of restrictive zoning can be read as part of a broader critique of both the contemporary city and those who have had a part to play in its formation. Much of this criticism is born from the perceived failures of modernism to meet the needs of the contemporary city and its inhabitants. Modernistic models of ordering the city, including New Urbanism, believe that formal models alone will remedy the problems of the city (Waldheim, 2006). This is reflected in the idea of a master plan, or the great reimagining of cities that occurred during the modernist movement. Le Corbusier's Ville Radieuse (1933), Frank Lloyd Wright's Broad Acre City (1935), and Ludwig Hilberseimer's The New City (1940), among others, put forth plans for massive formal reconfigurations as the solution to the ailments of the city (figs. 1.1.11,1.1.12,1.1.13). Contemporary examples would largely include New Urbanism's penchant for formal resolutions through a series of design guidelines and explicitly prescriptive checklists for city planning. Contrary to these readymade urban design kits, what many are arguing for, in the post-modernist spirit, is an open-ended processdriven approach that is more concerned with dynamic interactions than it is with formal resolution.

Such an open-ended process-driven approach is seen by Charles Waldheim, James Corner, and Stan Allen, the leading voices in the practice of Landscape Urbanism, as a multi-disciplinary, multi-phased, multi-programmatic approach - an approach defined largely by pluralisms as opposed to singularities. As a whole, proponents

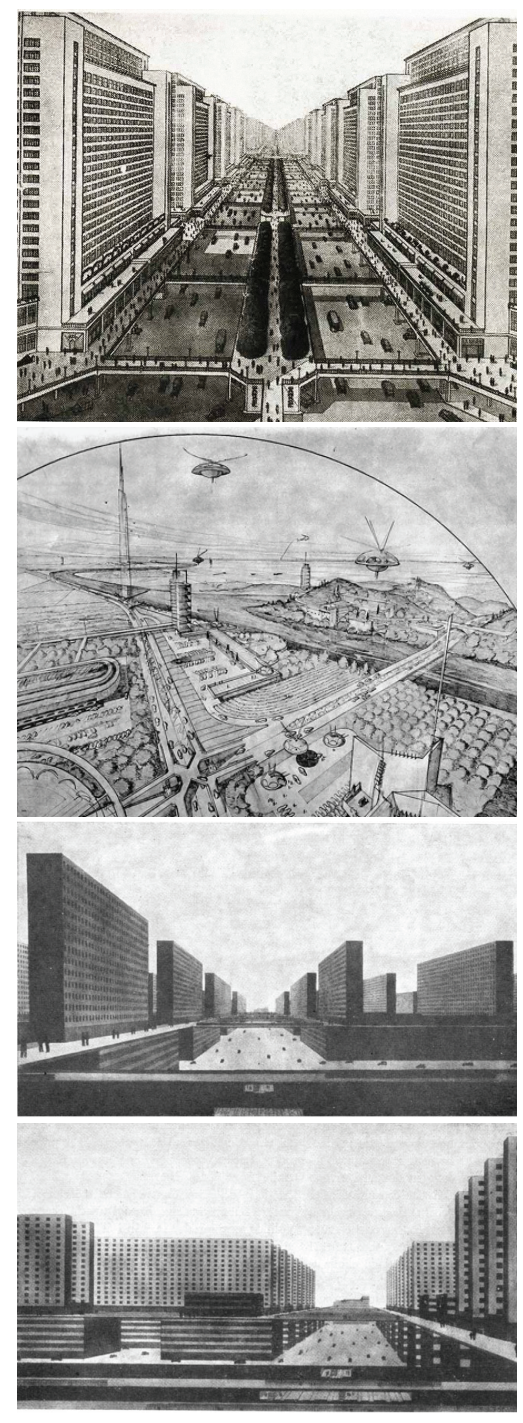

figs. 1.1.11, 1.1.12, 1.1.13 modernistic models for ordering the city Le Corbusier, Frank Lloyd Wright, and Ludwig Hilberseimer reinvision the modern city in grand, dissassociated master plans. 
Jane Jacobs large swatches of construction built at one time are inherently inefficient for sheltering wide ranges of cultural, population, and business diversity. They are even inefficient for sheltering much range of mere commercial diversity. Neighbourhoods built up all at once change little physically over the years as a rule. The neighbourhood shows a strange inability to update itself, enliven itself, repair itself, or to be sought after, out of choice, by a new generation. (Jacobs, 1961) of Landscape Urbanism believe that the interstitial space between buildings, the ill conceived spaces left-over from the modernist parcelization of the city, is the very ground on which to glue the city back together through a series of process driven, participatory, and dynamic interventions (fig. 1.1.14). The thinking is that as cities become increasingly decentralized, they are increasingly defined by their landscapes; landscapes that have enormous potential to act as a staging ground for uncertainty, adaptation, and feedbacks to the rapidly transforming conditions of the contemporary city; landscapes not obsessed with the object, separateness and boundaries, but with cohesion, productivity and complex relationships.

fig. 1.1.14 cpuls Continuous Productive Urban Landscapes represent many of the principles of landscape urbanism - landscapes which add cohesion, productivity, and continuity to an existing city structure.
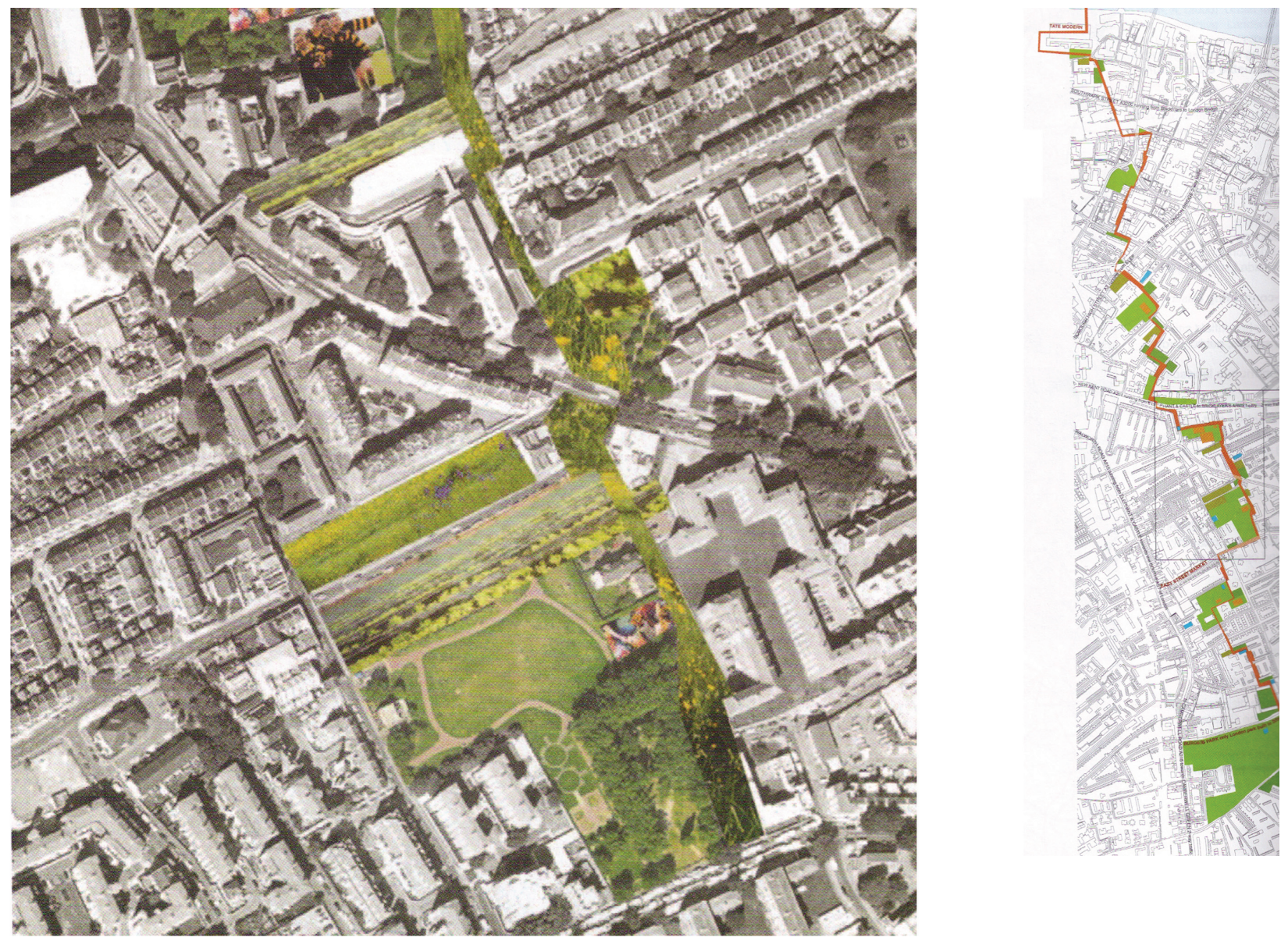


\section{2 the background}

\subsection{1 suburban context John Sewell, Former mayor of Toronto} and an authority on the history and makings of the city, believes that Toronto's suburban neighbourhoods should be preserved and that city planning should be done in consultation with local residents (Sewell, 2009). In his book The Shape of the Suburbs: understanding Toronto's sprawl (2009), Sewell gives a comprehensive history of the city's largest housing sector, it's suburbs, and shows that they were based not on uncontrollable growth (as is often believed) but on strategic planning mostly predicated on access to city water, highways, and other essential infrastructures (figs. 1.2.1,1.2.2). Sewell believes this planning was flawed from the beginning as we now have what Sewell calls un-walkable, un-liveable housing that is completely automobile dependant (ibid). Sewell touches on an important note, that the majority of Toronto's housing was built during a time of cheap energy and with the assumption that cars (and therefore oil dependencies) were always going to be a part of our lives.

The first explorations into the suburban typology were not based on cheap energy, but rather began as wealthy retreats for the upper class trying to escape the turmoils of the city. Master planned suburban developments, accessed by expensive steam railroads, became the testing ground for new patterns of living with examples including Llewellyn Park and Riverside (fig. 1.2.3), respectively designed by Llewellyn Solomon Haskell in 1853 and Frederick Law Olmsted in 1869 (Friedman, 2005). These early suburban enclaves began as examples of a new domestic ideal, but when new suburban developments began to replace the expensive and limited steam railroads with electric streetcars the suburban ideal quickly became

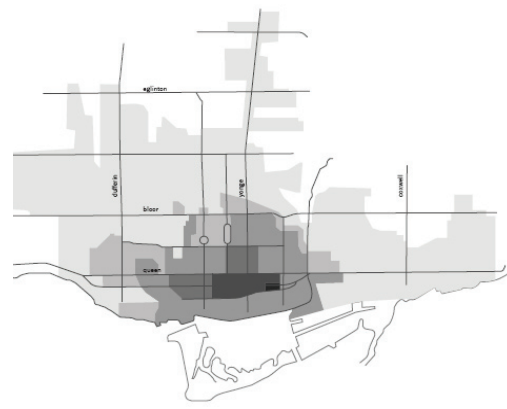

fig. 1.2.1 the growth of Toronto the growth of Toronto: 1793 townsite; 1800 expansion; 1850 expansion; 1890 expansion; 1900 expansion; 1914 expansion (streetcar suburbs)

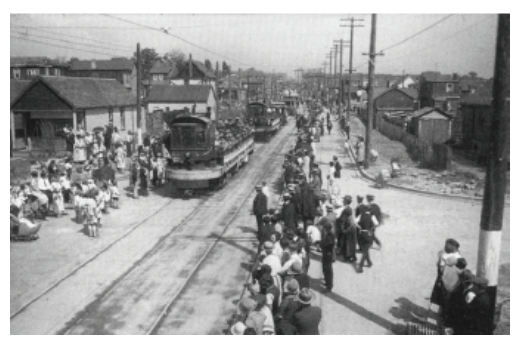

fig. 1.2.2 welcoming streetcar service, 1925 streetcars led to the rapid expansion of Toronto in what could be known as the first derivation of suburban sprawl. 


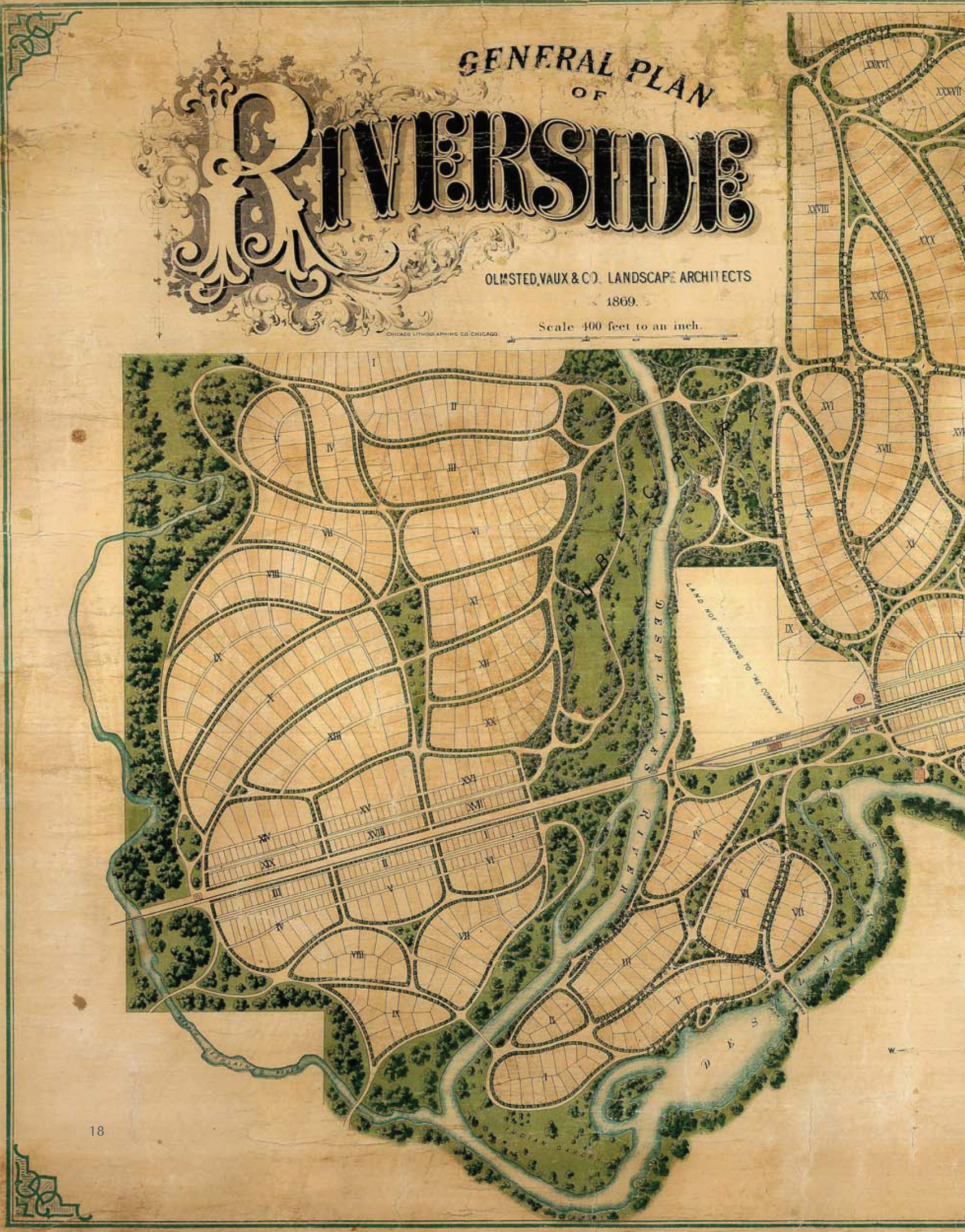


accessible to the majority of the public (ibid). The suburban condition that we see today did not come into being until the arrival of the widely accessible automobile which acted to increase the distance between the dwelling and employment, recreation, amenities, and the like. Suburban space became fragmented into independent archipelagos of separated uses that prevented programmatic synergies - productive frictions due to mixed use - to occur (Ruby, 2004). The suburbs, instead of being at the fringe of the city, became isolated pockets miles from the city center. As those pockets began to grow outwards with their increasing popularity they began to join together becoming a blanket otherwise known as sprawl.

The greatest misunderstanding in suburban thinking today is that all suburbs are the same. As Ilka and Andreas Ruby explain in the introduction to Architectural Designs The Challenge of Suburbia (2004):

Most discussions about suburbia today seem to be based on the notion that it is a subject that is universally valid. However, a closer look reveals that, though the 'suburban condition' is one that might share astonishing formal similarities with a standardized type such as the American subdivision, with its freestanding single-family houses defined by private gardens along cul-de-sac access roads, it is always drafted on circumstances that are locally specific. (Ruby, 2004)

In other words, there is no suburbia, only suburbias (ibid). Perhaps this explains the disparities between suburbs associated with crime and violence, suburbs that act as bedroom communities, suburbs that are home to engaged and active communities, suburbs that house wealthy families, or suburbs that house poor families, suburbs that sit empty due to the bursting of the housing bubble, or suburbs that are being rebuilt into mcmansions. Despite the varying economic and social conditions of each suburbia, the suburban paradigm is, and will always be, a blank screen for projecting hopeful futures onto (ibid). This intrinsic inclination for projection in the suburbs could be used as a hinge to impact the suburban paradigm, perhaps even to project a future born out of transitioning from vulnerability into resilience.

\section{opposite}

fig. 1.2.3 plan of riverside a plan of Olmsted's Riverside, one of the first suburban developments, 1869. 


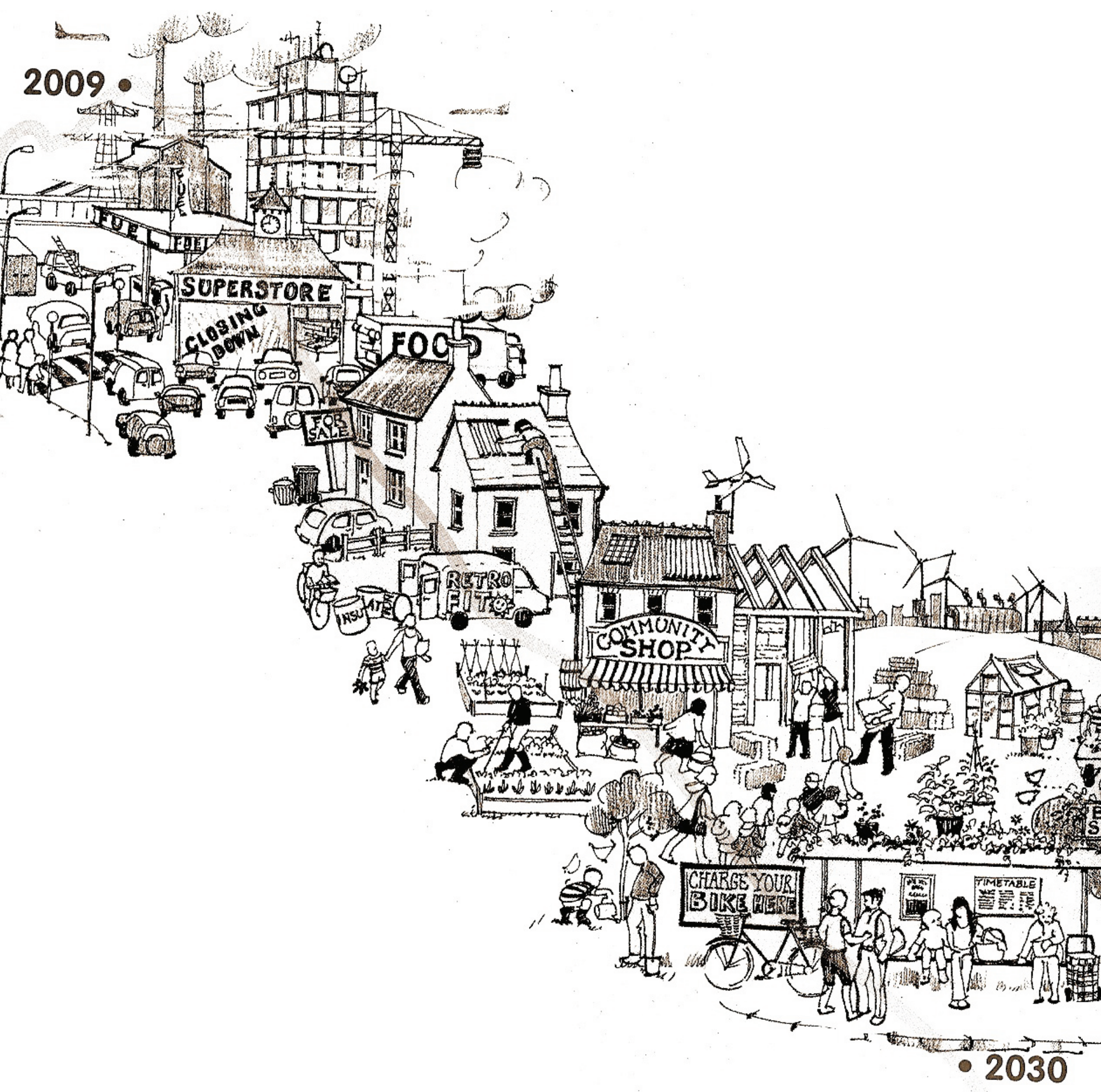




\section{opposite}

1.2.2 a history of transition The US oil shock of the 1970's was one of the earliest signs that there are limits to our dependant lives in this case our dependence on cheap energy in the form of oil. As Dr. M. King Hubbert predicted in 1956, the US oil reserves peaked in production and the nation experienced a serious and unexpected energy decent. The depletion of such oil reserves, and the trade embargo imposed by the OAPEC, proved to be quite a blow to the American economy with many US residents unable to function as usual (fig. 1.2.5). The negative effects of the 1970's energy crisis gave rise to innovative alternatives in technology such as solar power, solar housing, energy efficient homes, fuel efficient cars, and the like (fig. 1.2.6). But it also gave rise to a number of lifestyle alternatives including the proliferation of eco-villages such as Arcosanti. Arcosanti was designed according to the concept of Arcology (architecture + ecology), developed by Italian architect Paolo Soleri (Arcosanti, 2005). Soleri saw Arcosanti as an experimental model that would provide an alternative to urban sprawl, a way to house a high number of people within a small footprint, and a way to incorporate energy production, food production and water conservation within a city (ibid). The project is seen by many as a complete failure, with the city still in construction, very few inhabitants and very little funding. It is often read as a utopian, unrealistic dream driven on by youthful optimism. It nevertheless speaks to the spirit of the times that was spurred on due to an energy crisis.

Simultaneous to the ecological and conservational thinking emerging during the oil shortage, a grassroots movement was taking shape in the agricultural world. Permaculture, founded by David Holmgren and Bill Mollison, was developed out of the awareness of the limits of fig. 1.2.4 transition timeline a sketch from the transition town movement showing a positive decline from oil dependencies and a transition into resilient futures.

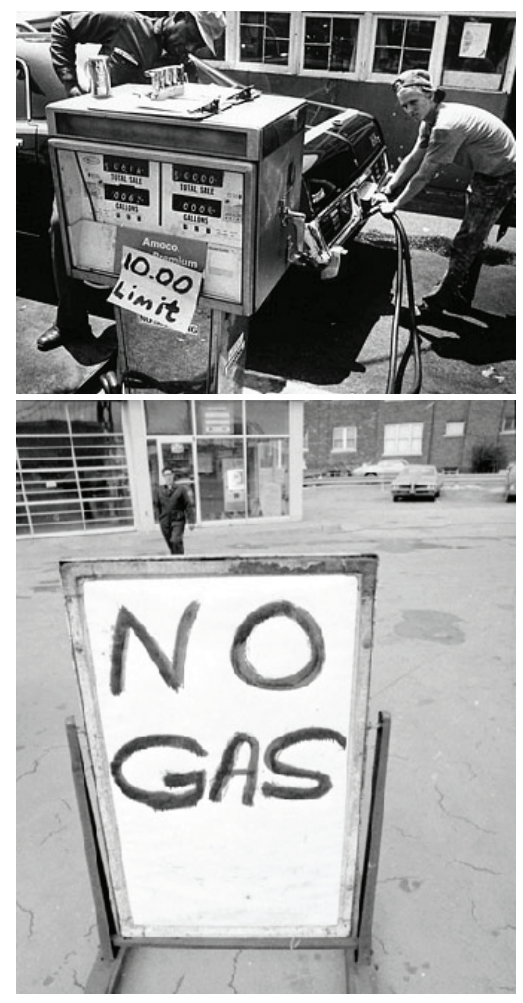

fig. 1.2.5 1970's energy crisis 


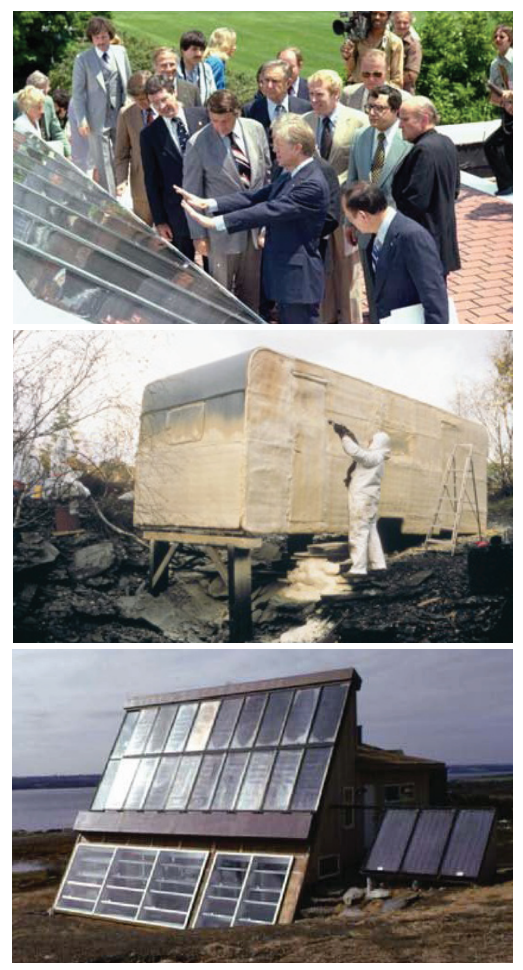

fig. 1.2.6 explorations into oil independence The energy crisis of the 1970's saw the advent of explorations into alternatives to oil dependencies, much of which was evident in the architecture of the period.
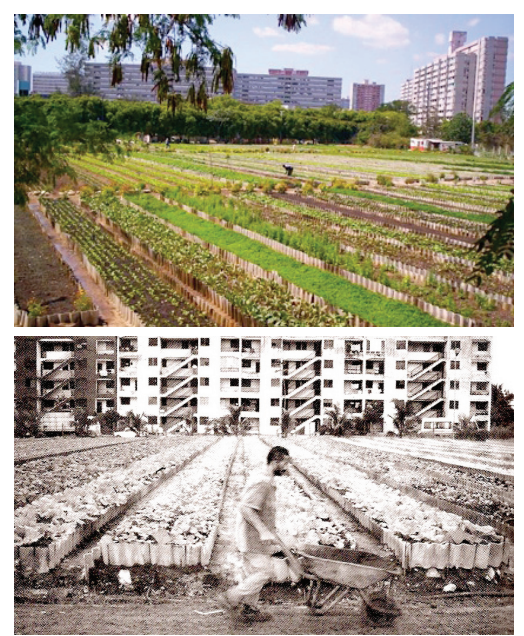

fig. 1.2.7 havana, cuba Havana, Cuba experienced it's own energy crisis and responded with the creation of grassroots urban agriculture to produce $67 \%$ of the city's needs. resources, due especially to the energy crisis of the 1970's (Fenderson, 2004). The concept of permaculture is based on a design system for creating sustainable human environments that use ecology as the basis for designing integrated systems of food production, housing, appropriate technology and community development (Permaculture Drylands Institute, 1989). In his book, Permaculture: Principles and Pathways Beyond Sustainability (2002), Holmgren explains how an oil crisis is actually the solution to our society's dependence on oil, stating that there is an opportunity to positively engage with energydescent and to learn and to change as we've done in the past (Fenderson, 2004).

It took nearly a decade to recover from the energy crisis, with the mid 80's seeing oil consumption return to its pre-crisis levels in North America. The tightening of the belts and creative responses to oil scarcity were soon dropped or became the pursuit of marginalized sub-cultures that were rarely given notice. The solar panels on the White House were taken down and energy efficiency was no longer important in policy or public discussions. Many of the ideas that surfaced in the face of the energy crisis were extensions of the back-to-the-land movement, and are often associated with countercultural high ideals, or naive youthful optimism. But it is interesting to imagine where we would be today if energy costs had remained high.

In 1989,Cuba experienced what many believe to be the foreshadowing of global peak oil. Following the fall of the Soviet Bloc and the US trade embargo, Cuba found itself without vital imports such as oil, oil products (including rubber, fertilizer, and pesticides) and heavy machinery (most importantly industrial agricultural equipment). Cuba's imports and exports were drastically reduced by $75 \%$ (Pena Diaz, 2005). As a result, the agriculture and food industries practically ground to a halt and food shortages occurred throughout the country. This was most severely felt in Havana where food availability was reduced by $67 \%$ (ibid). Throughout the 1990 's, in response to crisis, spontaneous plantings of backyards, terraces, and balconies occurred in Cuba (fig. 1.2.7) with no available equipment or previous knowledge of small-scale agriculture (Hen,2002). Shortly 
afterwards, Fidel Castro proclaimed that no land should be left unused and government incentives were put in place to encourage the fledgling urban agricultural measures that were beginning to take flight. Havana now produces almost $60 \%$ of its own food, with the remainder coming from just outside the city (Pena Diaz, 2005).

In 2003 the North-eastern US states and Southern Ontario experienced a crisis in the form of a multi-regional blackout affecting over 10 million people in Ontario and 45 million people in 8 US states (CBC, 2003). The sudden failure of the energy grid (later found to be caused by an overload of air-conditioning due to an extremely hot summer) left Toronto almost frozen in time and within seconds the city was unable to function. Without traffic lights the roads became chaotic, the goods within freezers quickly began to thaw and turn, and many were astounded by their inability to function without electricity. It is often stated that Toronto has approximately 3 days of food within the city. Luckily, the blackout lasted only 2 days, but left many wondering about their fragility in the face of such events (fig. 1.2.8).

\section{Democtat ầ Chromicle}

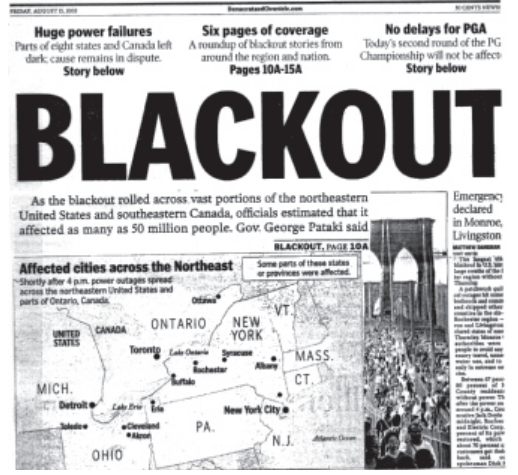

fig. 1.2.8 Toronto's blackout The great blackout of 2003 left many wondering about their fragility in the face of such a crisis. 
1.2.4 city as ecosystem In order to respond to crises, in order to endure and be durable to the uncertainties of the future, we must build resilience into our local environments by broadening the scope of our mechanistic world view. Thomas Homer Dixon has been an active voice in the call for rethinking our conventions and for the building of resilience into our physical, economic, and social environment. Outlined in his article The Century's Master Science (2009), sciences of the past centuries can largely be understood as a series of master sciences, each one directing the current thinking of that time period. He notes that in the 1800 's the leading science was chemistry - an offshoot of alchemy and the creation of new metals and chemicals on the basis of experimentation and combining various elements; and physics in the 1900's - the invention of the steam engine and the internal combustion engine, the study of air movement and wind patterns leading to the invention of the aeroplane, and the invention of atomic power. Dixon posits that ecology will be the new master science of the $21^{\text {st }}$ century and that the mechanistic worldview of the past is being discredited (especially in the face of economic and environmental uncertainties). Ecological thinking tells us that we shouldn't be surprised by surprise, that systemic crisis and even systemic breakdown are inevitable (Homer-Dixon, 2009). In order to avoid catastrophe, a complex-systems perspective suggests that we should build resilience into our critical technological, social and natural systems, so that they dont fall apart when hit by significant shocks. (ibid). The science of ecology is inherently holistic, looking at the complexities of natural closed-looped systems and cycles, and their webbed interconnectedness (fig. 1.2.9). The concept of resiliency is born from the study of ecology and the understanding of an ecosystem's ability to withstand, and adapt to, external pressures.
David Waltner-Toews Insofar as our species interacts with other species and the landscapes we live in, we are ecological beings; insofar as we consume and excrete nutrients and use energy, we are members of ecosystems. An urban landscape is certainly a social system. It is also as much an ecosystem as any rural landscape or wilderness. (Walter-Toews, 2008)

\section{opposite}

fig. 1.2.10 Jackson Pollack The chaos in Pollack's work is perhaps a symbol for the complex and infinite interconnectedness of an ecological system, and representational of the diversity of natural ecologies.

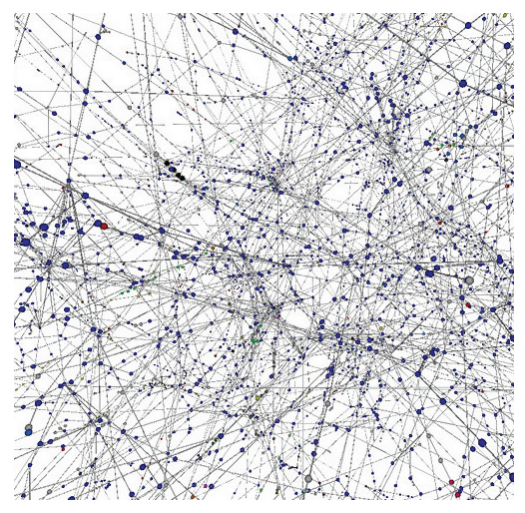

fig. 1.2.9 the non city The city as ecosystem is often understood as the non-city - or a city of multiple connections, multiple nodes of production; a city of complex interrelations and infinite networks. 

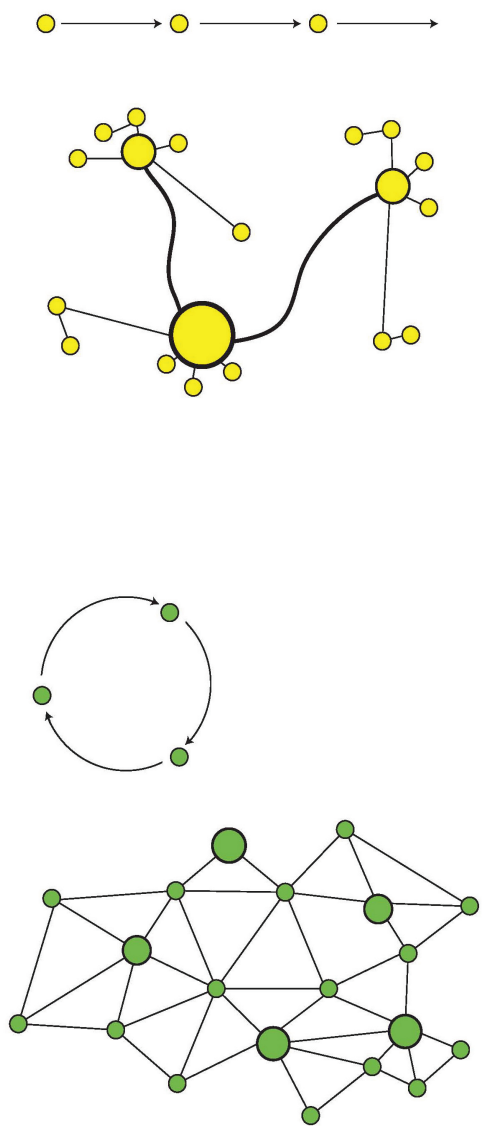

fig. 1.2.11 linear v.s. network Ultimately, systems which funtion in a linear fashion (in which resources enter one end and leave the other) are unresilient and liable to failure. At one end of the linear system is experienced depletion of resources, and at the other an accumulation of wastes. Cities must strive to become networked, where, as McDonough is found of saying, waste equals food.
Resilience is defined as the capacity of a system to absorb disturbance and reorganize while undergoing change, so as to retain essentially the same function, structure, identity and feedbacks (Hopkins, 2008). According to economist David Fleming, an organizational structure (such as a city) with built in resilience will benefit from the fact that if one part is destroyed, the shock will not ripple through the whole system (ibid). William McDonough states that if humans are going to prosper, we will have to learn to imitate nature's highly effective cradle-to-cradle system of nutrient flows and metabolism (fig. 1.2.11) (McDonough, 2002).

Charles Waldheim states in The Landscape Urbanism Reader that landscape is itself a medium through which all ecological transactions must pass - it is the infrastructure of the future (Waldheim, 2006). According to Landscape Urbanists, there is an implicit advantage in this urban perspective which comes from the integration and fluid exchange between the natural environment and engineered infrastructural systems - the potential for a complex interweaving of natural ecologies with social, cultural and infrastructural urban layers (Waldheim, 2006). Waldheim points out that ecologists are increasingly found on urban design teams and that their involvement in city building is becoming increasingly crucial. This has been the case with James Corner's proposals for Downsview Park, Fresh Kills, and the NYC High Line. Like Waldheim, Corner also draws on ecological systems to frame his understanding of urbanism. Central to Corner's work is the study of landscape ecology, a branch of landscape architecture that defines landscape very broadly as a mosaic of the total spatial and visual entity of human living space - a landscape that integrates the environment, living systems, and the manmade (Shane,2004). Landscape Ecology emerged as an appendage of land planning in Germany and Holland after the Second World War, but was not studied in North America until the 1980's when Corner was a student at the University of Pennsylvania (Shane, 2004). The theories of Landscape Ecology likely resonated with Corner and Waldheim during their studies at Penn under the distinguished landscape architect, and ecological advocate, Ian McHarg.

Frederick Steiner states in his essay Living Urban Landscapes that such 
ecological emphasis represents a fundamental shift in how we view the health of our cities (Almy, 2007). Despite what is often promoted as a novel idea, the theories of ecological urbanism are in fact born from an inheritance of sound theoretical work which spans the last several decades. Lewis Mumford, in his work Technics and Civilization (1934) and The Culture of Cities (1938), was clearly a pioneer in ecological urbanism as his writing focused on the incorporation of diversity and pluralisms into our built environment. Indeed, Mumford's work contains some of the earliest and most succinct writing pertaining to ecological urban planning, bio-regionalism, and biodiversity (Almy,2007). In 1969, lan McHarg, caught in the current of environmentalism and the progressive critique of humankind's impact on natural systems, wrote extensively on the need for ecological balance and the imperative to design with nature. In Design with Nature, McHarg's diagrams on the ecological systems present in Staten Island show not only the diversity of ecological features present on the island, but also the potential for ecological incorporation into an already occupied urban context (McHarg,1969). Richard T.T. Forman, the renowned landscape ecologist, wrote in 1990 of the need for sustainable environments through what he called a mosaic stability of adaptability, ecological thinking, and slow changes over time (Almy, 2007). Rem Koolhaas in 1995 wrote of the need for intensification, diversification and infrastructural linkages to bring together a staging for uncertainties and a territory of potentials (Almy, 2007). As humans increasingly locate themselves within cities our ecological literacy expands and urban systems are increasingly understood as complex ecologies. Landscape Urbanism's rich background in ecological study offers many cues for an urbanism wanting to structure the flows of populations, activities and ecological needs of a city.

A central tenet of Landscape Urbanism is found in its emphasis of the temporal component and the role of time in the life of a city. Design as a temporal occurrence is not a new concept to Landscape architects. In fact, the very underpinnings of landscape architecture rest in the understanding that the climax of a landscaped setting occurs many years after the realization of the project. If allowed and planned for, such a project would continue to evolve and would experience multiple zeniths throughout its life. Landscapes of this nature are in a continuous state of change and growth and are
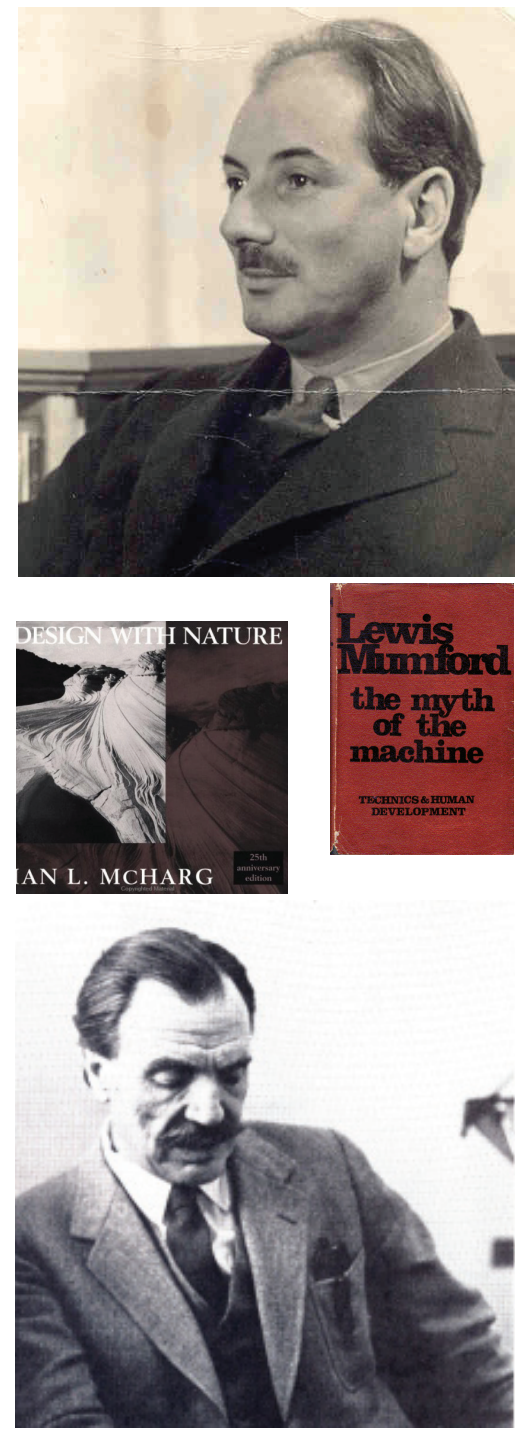

fig. 1.2.12 forefathers of ecological urbanism Lewis Mumford and Ian McHarg were amoung the earliest theorists in ecological urbanism, both argueing in their own time for the incorporation of multiplicities into our urban environments. 
participating in the temporal element (fig. 1.2.13) - something that is severely lacking in most urban environments and something that is rarely considered in the study of architecture.

In the introductory text of Landscape Urbanism: A Manual for the Machinic Landscape,coeditor Mohsen Mostafavi, former chair of the AA,describes the tenuous relationship between landscape and the modern city (Fulton, 2005). He states that as a framework for the imagination, landscape produces new insights in response to the contemporary urban situation and goes on to explain that such new insights require the rethinking of the traditional boundaries between landscape architecture and architecture (Mostafavi, 2003). Charles Waldheim, in his essay Landscape as Urbanism, states that landscape is a medium uniquely capable of responding to temporal change, transformation, adaptation, and succession (Waldheim, 2006). Such qualities make a city's landscape the medium through which urban transformation and evolution can occur. At one extreme, landscape ecologist Richard T.T. Forman states in his essay Ecologically Sustainable Landscapes that a constant world is impossible, it is ever changing (Almy, 2007) and suggests that a city that can adapt to future uncertainties will inevitably be a stronger, more resilient city. James Corner, principal of Field Operations of NY City, is critical of the modernist urbanist treatment of time, believing that modernist ideologies set the stage for strict, rigid, regulatory measures to keep the city in a certain form, but that these ideologies were not derived from any processes moving
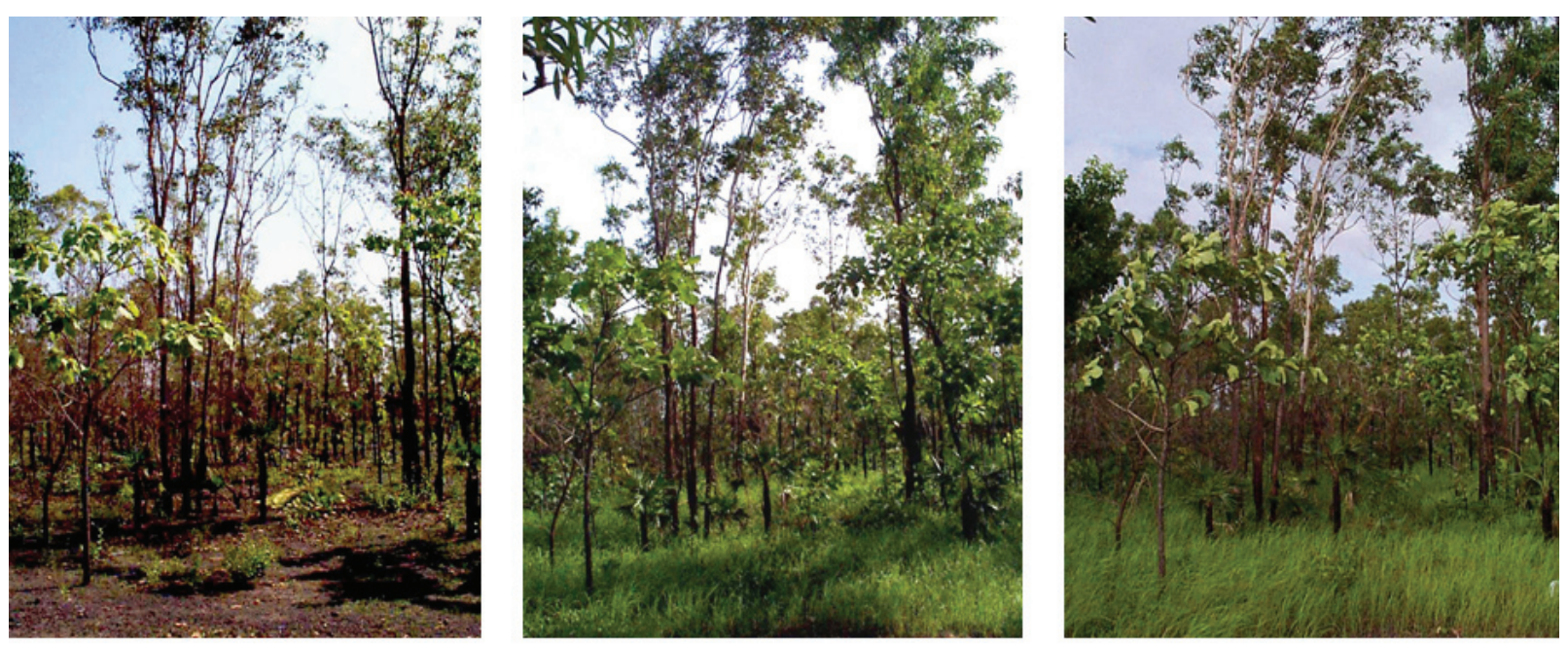
through the city nor did they redirect any processes moving through the urban environment (Waldheim, 2006). Contrary to modernist urbanism, a temporal approach to urbanism attempts to set up a range of programmatic configurations as seasons, needs, climates, economies and political structures change and play out over time - the root causes of indeterminacy in the city. The thrust of temporal urbanism is less toward formal resolution and more toward public processes of design and future appropriation - thus anticipating change, openendedness, and negotiation (Almy, 2007).

According to Stan Allen, urbanists, architects and landscape architects should strive to develop practices that are engaged in process, practices not devoted to the production of objects, but rather to the production of directed fields in which program, event and activity can play out. In theory, such process-based approaches will lead to ecologically, economically and socially rich environments - urban settings which are allowed to phase from one state to another as time progresses, environments that can be appropriated and modified by the public to enable a diverse and flexible range of uses (Waldheim, 2006).
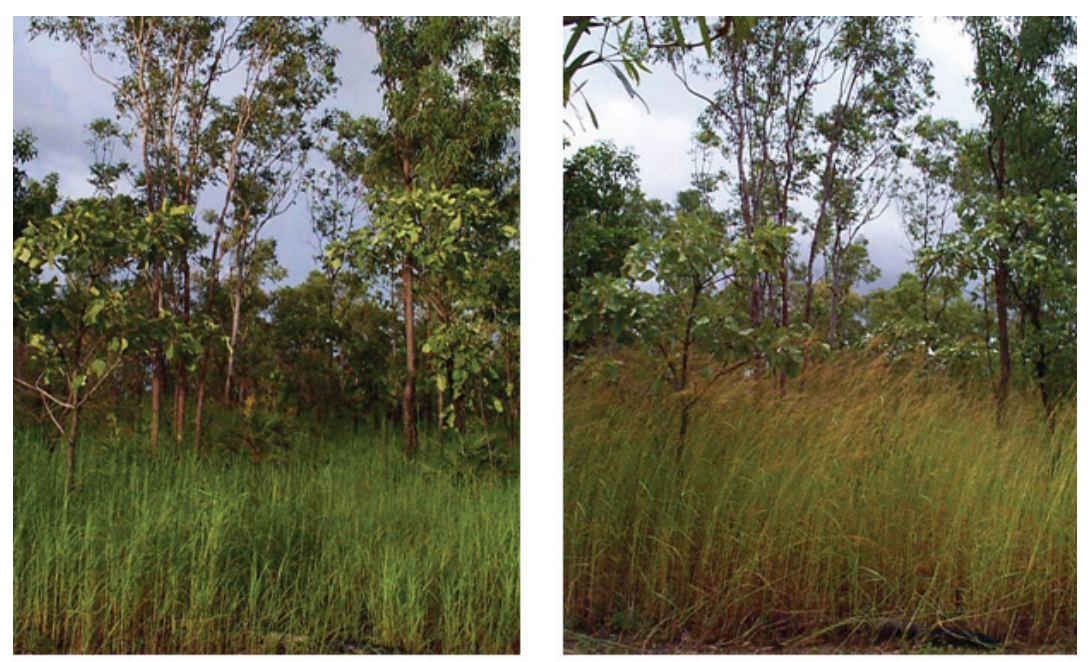

David Waltner-Toews By understanding the interdependence of ideas of nature, science, and society, we can better understand how the ecosystem approach can address the challenge of fostering respect for, and nurturing the sustainability of, the ecosystems that are our home. (Walter Toews, 2008)

fig. 1.2.13 succesional sequence landscapes are inherently functioning with time, constantly in a process of change. Our built environment too is involved in the process of change, but this is rarely admitted or planned for. 
Bert Archer More recently, there has been a different sort of city spirit, rising from people who get off on Toronto not because they should, or because it happens to be where they live, but for the city's inherent qualities. It's a Zeitgeisty sort of thing thats finally wafted into town and not the result of any particular organization or movement, though, in the way of such things, people have congregated around the casually cohesive groups such as those responsible for Spacing magazine or the Toronto Public Space Committee or the [murmur] project. (Wilcox, 2007)

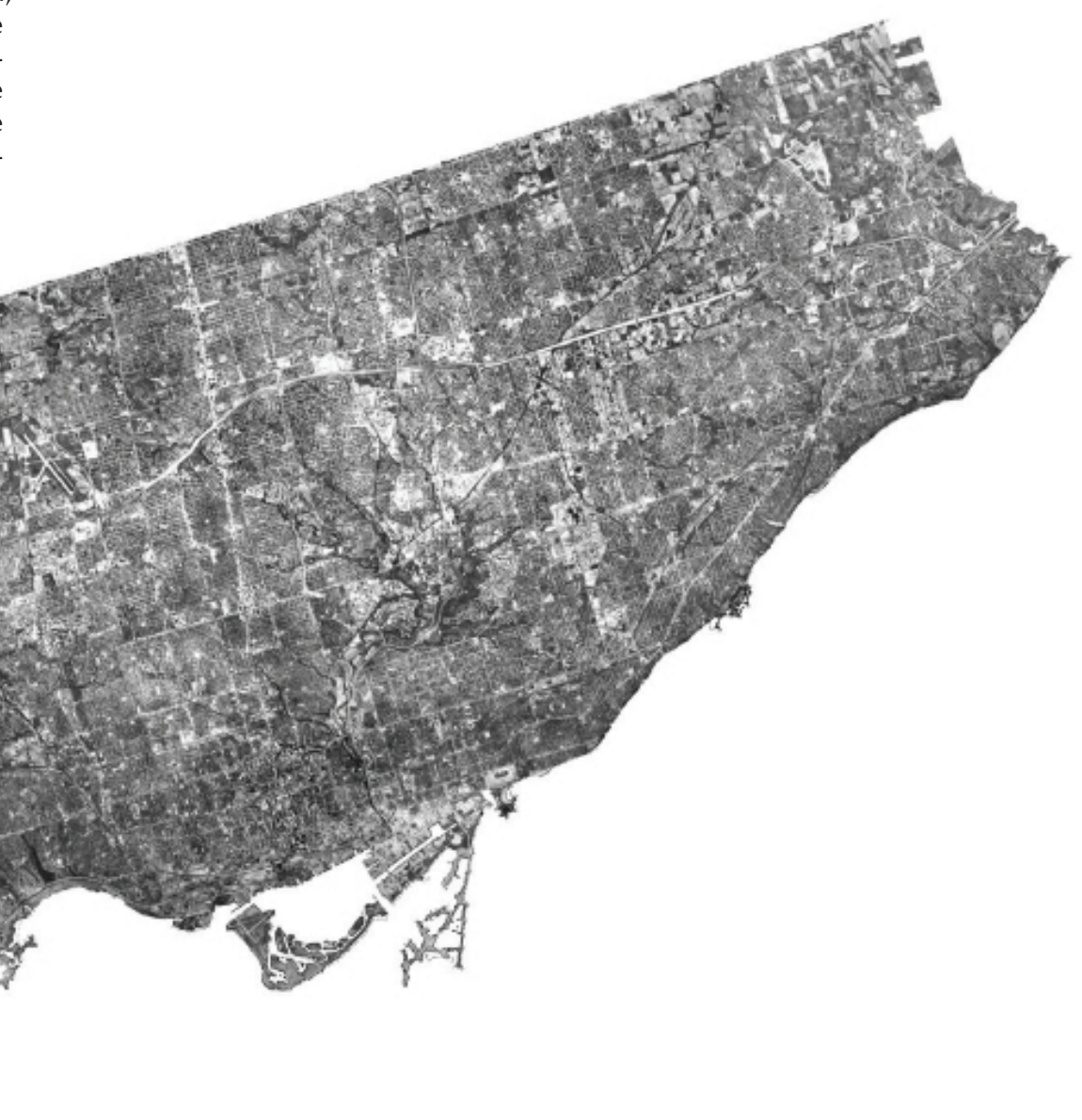

fig. 1.2.14 aerial of Toronto

Jason McBride [Toronto] now seems a city of extraordinary possibility. We are contributing to Toronto's growth by refusing to accept its limitations or, rather, by turning those imitations into virtues. We are creating culture. We are reclaiming public space. We are transforming neighbourhoods. We are rediscovering or recovering history. We are trying to make home feel more like home. We are telling people that we live in Toronto with a proud smile instead of an embarrassed titter. (Wilcox, 2007) 
1.3 the potential The City of Toronto has been the focus of a number of progressive projects that propose, essentially, a transition away from contemporary city planning and into a resilient urban framework. GreenTOpia (2007), the $3^{\text {rd }}$ instalment of the uTOpia: Towards a New Toronto series presents a number of such discussions. The projects presented range from Chris Hardwicke's re-examination of the city's ravines and how they can act to feed the city (fig. 1.3.3), to Heather Marie Annis's Quick Fix solution of cutting back on the Tim Hortons paper cups found in Toronto's garbage (Wilcox, 2007). RVTR propose extensive food production in underused portions of the city, including under the Gardiner Expressway, around tower blocks and on suburban lawns - food production that would provide Toronto with $50 \%$ of the it's food needs (fig. 1.3.4) (ibid). Another highlight of Toronto's changing face, one that has 3 pilot projects underway, is the Mayor's Tower Renewal project which proposes a major renovation of over one thousand of Toronto's 1960's concrete slab residential towers (fig. 1.3.1). The main drive for this proposal, backed by Mayor David Miller and receiving lots of press, is to preserve the embodied energy of these durable concrete towers. The salience in ERA Architect's vision is in the creation of green infrastructure dispersed throughout the city by converting the distributed inventory of tower blocks into productive nodes (fig. 1.3.2) (ERA Architects, 2008). Taking cues from ERA's versed proposal for tower renewal, how can Toronto's largest housing sector experience its own renewal - a suburban renewal?

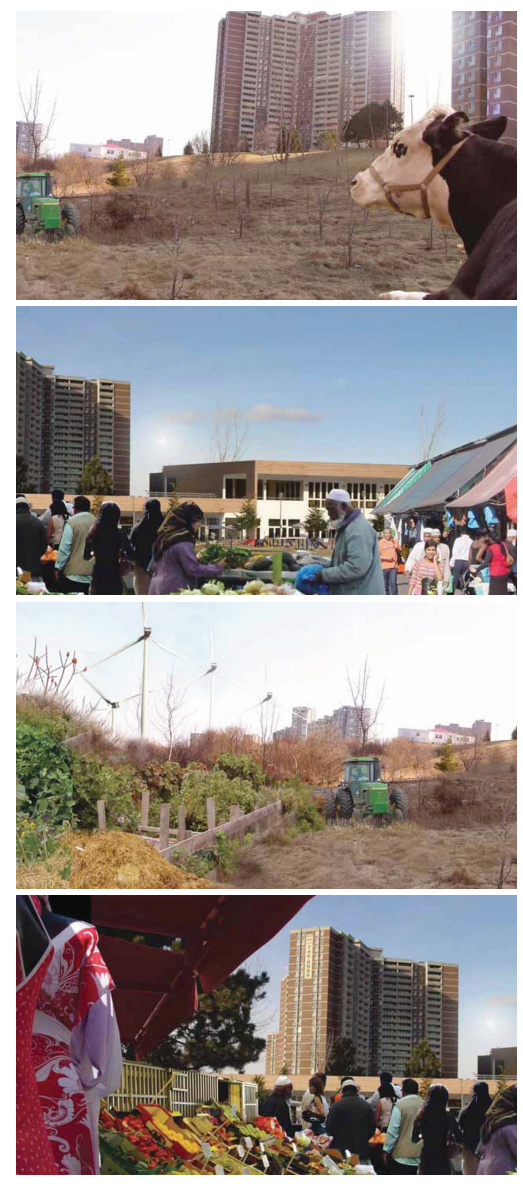

fig. 1.3.1 the mayor's tower renewal The Mayor's Tower Renewal is one of the most compelling proposals for introducing resilience into Toronto's built form. 


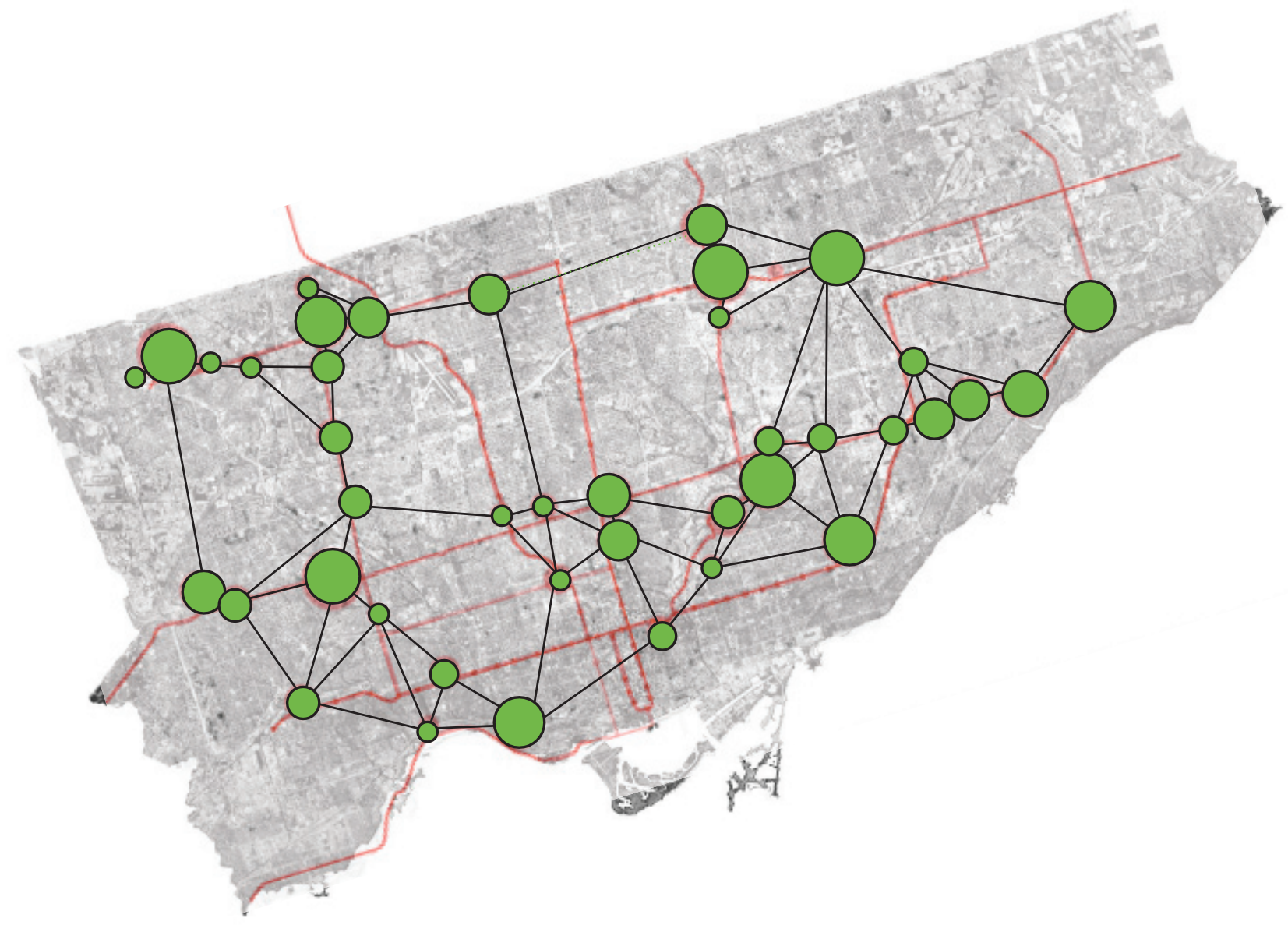

fig. 1.3.2 mayor's tower renewal as network By linking the various locations of tower blocks throughout Toronto, the beginning of a connected network can be seen. With each node creating its own district energy, source of food and clean water, employment and amenity space, Toronto will begin to build resilience into it's urban fabric. 

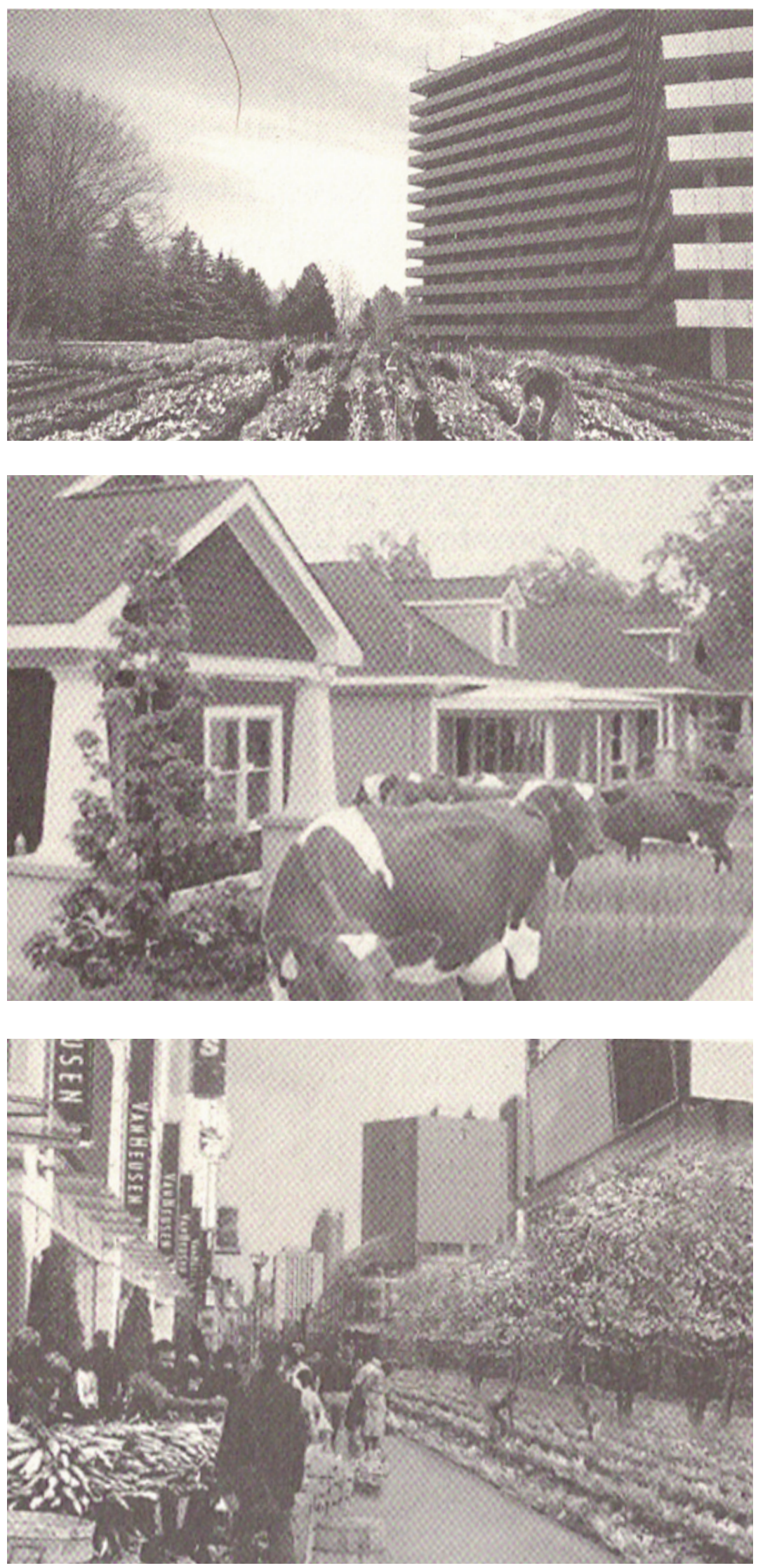

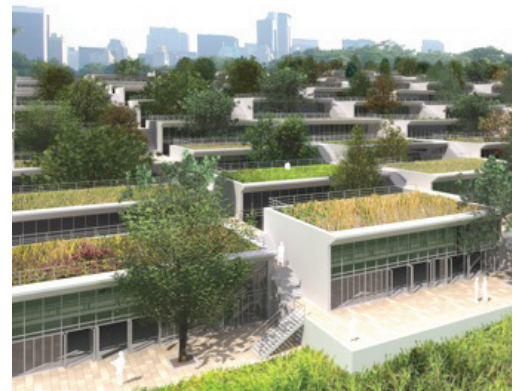

fig. 1.3.3 ravine city Chris Hardwicke's proposal for converting Toronto's ravines into productive, inhabited ecological corridors of the city.

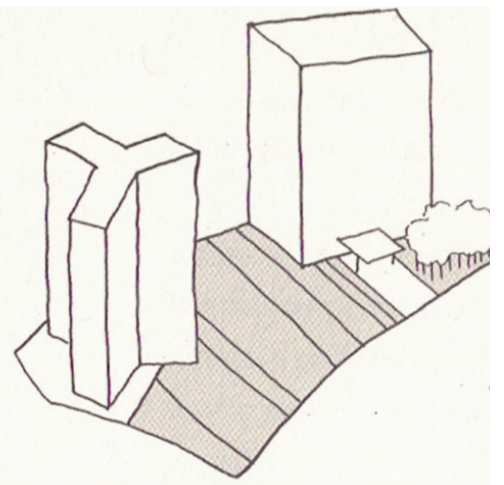

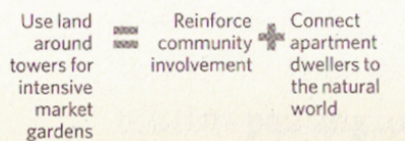

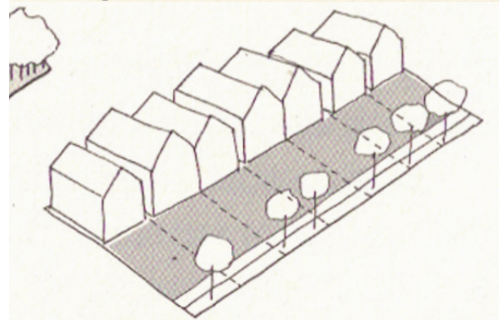

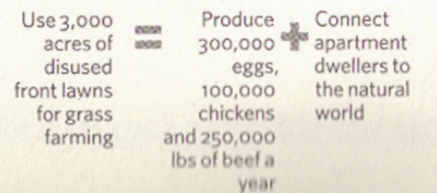

fig. 1.3.4 under-used areas of Toronto feeds city RVTR's proposal for converting underused portions of the city into highly productive landscapes to feed the city. 
fig. 1.3.5 architecture 2030

$75 \%$ of our built environment will be new or rebuilt within the next three decades.

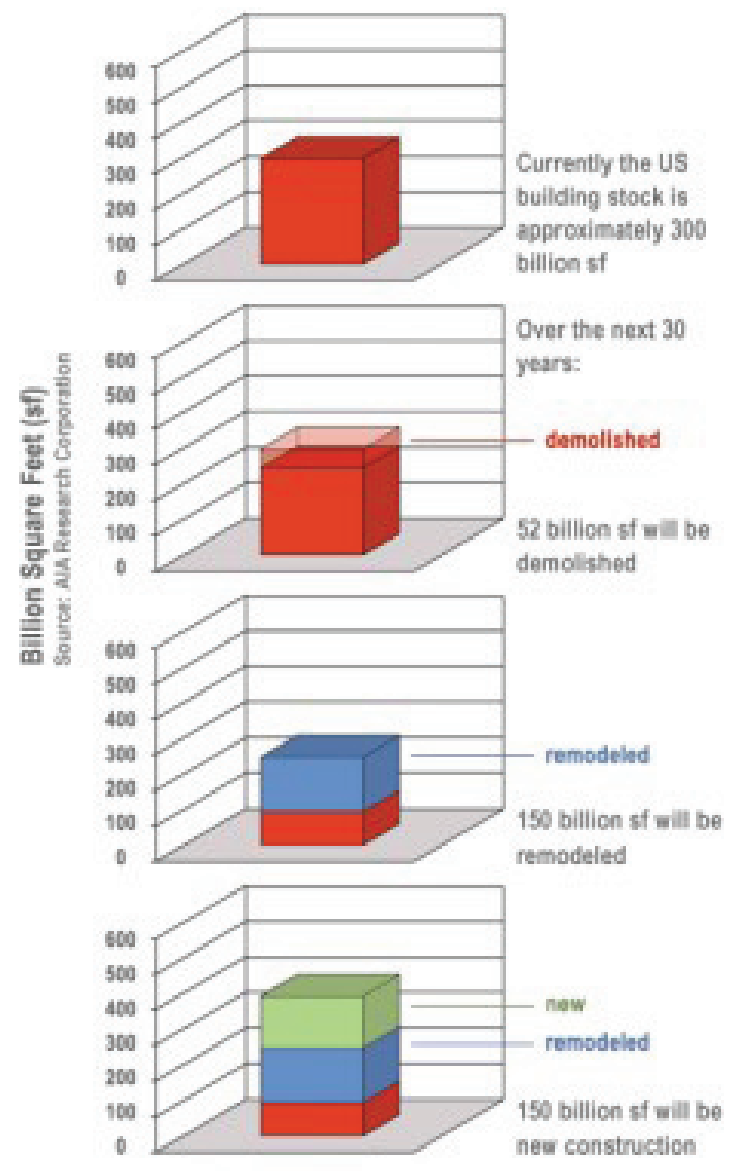


1.3.1 a market for suburban renewal Architecture 2030, an organization advocating the need to renovate our existing building stock by the year 2030, makes a compelling case for the renewal of our cities. According to their research, in the next 30 years only $15 \%$ of our building stock will be demolished while $50 \%$ will be retrofitted and an additional $50 \%$ will be newly built (fig 1.3.5) (Architecture 2030, 2009). As their numbers indicate, in 30 years $75 \%$ of our building stock will be new or renovated. With such a considerable projected revamp of our existing building stock, renewal of Toronto's suburbs within the next 30 years is tenable.

Residential renovations in Canada already account for $\$ 20$ billion of the $\$ 123$ billion building industry (Leach, 2008). A CMHC investigation showed that two out of every five households in Canada made renovations in 2007 with an average budget of \$13 000 being spent on each renovation (Leach, 2008). This is indicative of a substantial residential renovations market, accounting for 1/6th of the entire Canadian building industry. A recent proposal by Architecture 2030 posited that with investments based on the current governmental stimulus packages ( $\$ 20$ billion into the Canadian public building sector) the renovation market could grow to be larger than the new-construction market (Mazria, 2009). Their argument rests in the fact that the private sector accounts for $93 \%$ of the building sector, and that investments made here (rather than into the public sector) would generate demand for construction services, products, private investment and spending on a much larger scale than public infrastructure ever could (Mazria, 2009). 
To investigate the growing interest in green renovations in the residential sector, RBC randomly selected and surveyed 4000 Canadian homeowners and the results are as follows (RBC, 2008):

$60 \%$ of renovations for 2009 included green options $(30 \%$ of which did so for energy concerns). Yet, 76\% stated that they would choose green options only if it saved them money in the end.

Canadians are intrigued with the idea of living off the grid, with $51 \%$ saying they would actually consider such a change.

Net Zero Houses appear even more appealing to Canadians with $66 \%$ saying they would consider green options that would allow their homes to produce more energy than they consume, and therefore create revenue by selling back to the grid $(71 \%$ believe that this is a possibility for their homes in the next 5 to 10 years). (RBC, 2008)
By situating their data within the Canadian context we can see the following possibilities. Canadian infrastructure stimulus package of $\$ 20$ billion invested into the private sector would create (Architecture 2030, 2009):

900000 new jobs versus 180000 new jobs created through public sector investment

\$100 billion in direct, non-federal investment and spending (taxation on this would pay back the original stimulus package amount)

a new $\$ 23.6$ billion renovation market that could grow to $\$ 260$ billion by 2030, and over $\$ 547$ billion by 2069

Although only a statistical projection, Architecture 2030's proposal demonstrate the tremendous potential for the renewal of our existing building stock within the next few decades. From a market viability standpoint, there is, and will increasingly be, an economic case for making changes to Toronto's suburbs.

When this economic case is linked to the projected population growth the GTA will soon experience (an additional 2.7 million residents by the year 2031) (Tyndorf, 2002), and the ever-present pressures of the greenbelt and smart growth policies, it is clear that changes will need to be made to the relatively low density suburban neighbourhoods throughout Toronto. As will be discussed later in this report, architects have a crucial role to play in the redefinition of the suburbs; a role that, due to political, economic and social pressures has been absent in the suburban discourse. 
1.3.2 existing policy models Two policy models currently exist in Ontario that would directly affect the potential for renewal in Toronto's suburbs.

\section{Co-operative model (Co-op)}

In the face of failed housing models of the 1960's (large government owned housing projects), the 1970's saw the birth of Canada's fledgling co-operative housing movement - a movement that encouraged the national government to change its policies in support of smaller scale, mixed income housing. A housing co-operative is a legal entity often a corporation - that owns real estate consisting of one or more residential buildings. Over the past 30 years, Canadian housing cooperatives have had a sound record for producing cost-effective, selfgoverned communities based on sustained public-private partnerships and participation in broader social issues (Unesco,2010). The success of the co-operative housing model can largely be attributed to the empowerment of average Canadians to democratically manage their neighbourhoods, enabling community-based not-for-profit organizations to sponsor, build, own and manage their neighbourhood housing. The cost effectiveness of such co-operative models are derived from high volunteer participation levels by co-op members, and through the access to federations and resource groups that serve Canadian co-ops at relatively low costs (Unesco, 2010).

From the first handful of co-operatives built in the 1970's, Canadian co-ops have grown in number to more than 2000, housing over 90 000 households and 250000 people throughout Canada (Unesco, 2010). Co-operative housing neighbourhoods can range from less 
fig. 1.3.6 co-op model The cooperative model involves a range of members and a highly organized approach to overcoming city bylaws and working collaboratively to elicite change within the built environment of the co-operative neighbourhood. than ten to more than 200 units, but typically contain between 50 and 80 households (Unesco, 2010). In a number of cities across Canada, housing co-operatives have played an important role in redeveloping urban spaces,creating livable,walkable and vibrant communities within existing developments. Many Canadian Co-operatives have received recognition for their achievements in residential design, architectural innovation, urban planning, energy efficiency and restoration of heritage housing stock (Unesco, 2010). Over the past few decades, housing co-ops have also provided exemplary solutions for energy and water conservation, productive landscaping, healthy environments and reductions in the use of automobiles (Unesco, 2010).

The Canadian co-operative housing model has had substantial influence in promoting changes to the legislation and regulatory structures throughout Canada. This new legislation has led to the subsequent impact on by-laws and policies which co-ops utilize in their institutional framework and operations (fig. 1.3.6) (Unesco, 2010). The co-operative housing model has much to offer in the understanding of suburban renewal in Toronto.

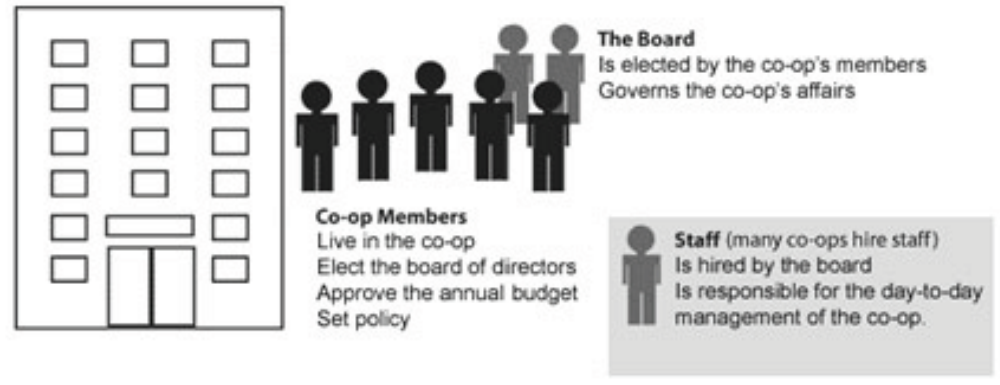

Development Permit System (DPS)

In 2006, the Growth Plan for the Greater Golden Horseshoe was introduced under the authority of the Places to Grow Act,2005. The plan presented a comprehensive 25 year vision for the Greater Golden Horseshoe with policies projected to create complete communities that offer more options for living, working, shopping and playing. Policies were put in place to curb sprawl and protect farmland, 
reduce traffic gridlock by improving access to a varied range of transportation choices, as well as to promote greater housing type choices to meet the needs of a range of people (OMMAH, 2008).

Working in conjunction with the Growth Plan,the Ontario government has recently introduced a new land use planning system, the DPS, that will give municipalities the autonomy to conduct changes to their zoning and by-law ordinances to promote vibrant communities in which people want to live, work, play and invest. The DPS is a land use approval framework that provides more tools for municipalities to address local planning issues, promote community building and facilitate streamlined development $(\mathrm{OMMAH}, 2008)$. Municipalities can use the DPS in all or parts of their municipality to make more efficient use of land and resources, protect natural and cultural heritage sites, create community facilities, or make local changes to by-laws and zoning ordinances (OMMAH, 2008). Similar to zoning bylaws, a DPS bylaw outlines how land may be used, where buildings can be located, what types buildings are permitted, how they may be used and the lot sizes and dimensions including building heights and setbacks from the street. What is crucial, however, is that a DPS replaces the underlying zoning and site plan bylaws in the area in which it is applied. A DPS can, in effect, create pockets of distinct zoning and bylaw ordinances applicable to the area defined in the DPS documentation. Residents are directly involved in the creation of a DPS, in the detailing of its criteria and in the creation of a new vision for their neighbourhood.

Unlike traditional zoning bylaws, a development permit bylaw can be used to set out discretionary, flexible uses (OMMAH, 2008). The ability to allow variations in standards for development reflects the incorporation of the minor variance process into the DPS, thus providing communities with the flexibility to deal with site specific circumstances and reduce the need for amendments to the bylaw (fig. 1.3.7). Such zoning flexibility and open-ended programming would allow communities to insert mixed-use programs into their neighbourhoods, while encouraging the accumulation of new buildings and/or changes to existing buildings to occur.
Similar to zoning bylaws, a development permit bylaw outlines (OMMAH, 2008):

How land may be used

Where buildings and other structures can be located

The types of buildings that are permitted and how they may be used

The lot sizes and dimensions, parking requirements, building heights and setbacks from the street. 

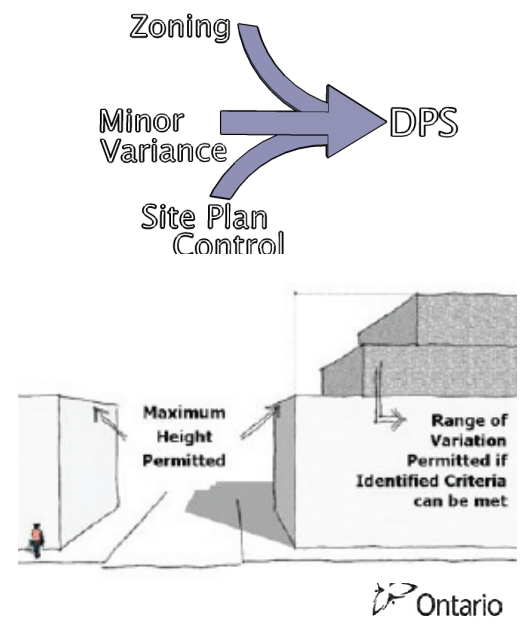

fig. 1.3.7 streamlined DPS model The DPS model allows for streamlining zoning, minor variances, and site control into one land use approval framework. Under this framework, changes can be made to municipal zoning ordinances and restrictive by-laws.
The DPS can be used in a variety of ways to achieve a number of land use planning goals and objectives. For example, a municipality may wish to establish a DPS in all or part of its community to (OMMAH, 2008):

Promote transit and pedestrian oriented development

Add streetscape amenities

Promote energy conservation and green infrastructure (e.g. green roofs)

Facilitate and encourage responsible and appropriate development

Protect important local and provincially significant natural heritage features

Curb urban sprawl through the promotion of the redevelopment of brownfield sites

Reuse and preserve heritage buildings, conservation districts, and landscapes

Encourage building design that is both innovative and respects neighbourhood character.

Although zoning ordinances have traditionally kept suburban developments the preserve of volume house builders and developers, the Co-operative model and the DPS approach may be the best starting point for suburban renewal in Toronto. These existing policy models certainly suggest the beginning of an open-ended,community driven approach to land use planning and an entry point for redesigning the renewal of Toronto's suburbs. 
1.3.3 suburban space and architecture Despite the fact that renowned landscape architect, Frederick Law Olmsted, is considered the father of the American suburb, architects have had little engagement with suburban developments. Marketing analyst Laurie Volk of Zimmerman/Volk Associates estimated that one particular design accounts for as much as 30 percent of all new single-family detached housing throughout the United States (Borden, 2007). There are many reasons why architects haven't been involved in the design of one of North America's largest building sectors. As mentioned before, economic and planning restrictions have kept the suburbs the preserve of volume house builders and speculative developers. There has also been some pretensions and resistance against architects working in the suburbs (Ruby, 2004). In contrast, Thomas Emodi, author of Emerging Urban Spaces in the Suburbs, believes architects have had a condescending attitude towards the suburbs, and that they seem to overlook the opportunities for innovative experiments in urban living that could be conducted in suburban environments (Friedman, 2002). In the book Suburban Space (2002), Renee Chow explains the absence of the architect in the suburbs and the role architects should be playing in the re-envisioning of suburban space:

Although we pretend that suburban houses are independent from one another, they are in fact interrelated, and their interrelationship needs to be acknowledged and designed. Seeing the suburbs as a fabric - a continuous structure of spaces in which we reside and through which we move and look - allows designers to describe relations not just within but among the houses. When the suburbs are seen as a fabric, the attributes for which they have been criticized - lack of community, homogeneity, and the waste of land and resources - can be re-evaluated as the consequences of accepting an overly simple aggregation of discrete and independently structured masses. With a weaving of a fabric for dwelling - a weaving of people to places, houses to 


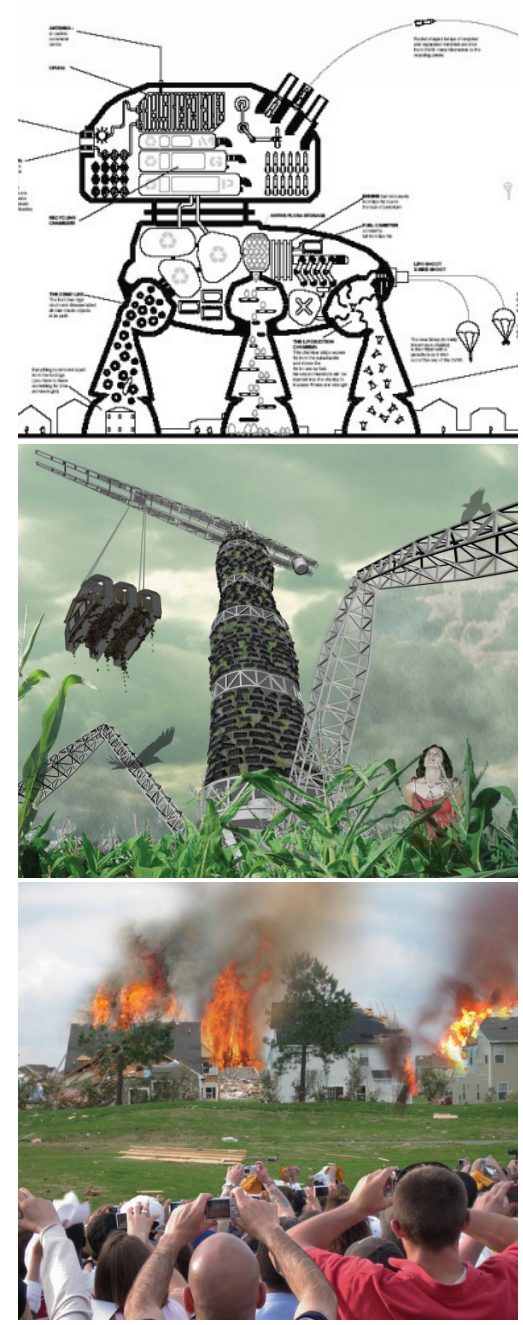

fig. 1.3.8,fig 1.3.9, fig 1.3.10 stamp out, burn, stack Designers Andrew Maynard Architects, Hughes \& Wake, and Degoutin \& Wagon envision a brutal end for suburbia, suggesting stamping out, burning, and stacking of suburban homes to erase suburban neighbourhoods from the face of the Earth. setting, indoors to outdoors - the discipline of architecture is reinserted into the suburban housing debate. (Chow, 2002)

Despite the vast potential for the weaving back together of the suburbs, some argue that the suburbs are a lost cause. In addition to his denouncement of the suburbs as future slums, James Howard Kunstler believes that suburban developments are the greatest misallocation of resources in all of human history, and that anyone arguing to rethink suburbia is trapped in a psychology of previous investment (Kunstler, 2005). Despite the prevalence of suburban neighbourhoods, Kunstler views the suburbs as something that should be abandoned, that we should cut our losses and return to the city cores. He is not alone, with tongue-in-cheek designers Maynard, Degoutin, and Wake also depicting the suburbs as unfortunate mistakes. They each suggest stamping out, burning, and stacking of suburban homes to remove, rather than re-imagine, such suburban neighbourhoods (figs. 1.3.8, 1.3.9, 1.3.10) (Reburbia, 2009).

However, as respondents to the 2009 design competition ReBurbia (2009) note, unconstructive criticisms like these are often made by those that do not, and have never, lived in suburban neighbourhoods. Such critics are quick to judge the suburbs as something that needs erasure and replacement with urbanity (ibid). New Urbanist models often enter the suburban discussion from this angle, assuming that to make the suburbs more liveable we must make them into dense urban environments. In a study by DPZ, Suburban retrofit and infill (2008), solutions are put forward for urbanizing the suburbs, but very little is said about enhancing or adding to the existing suburban qualities. It is these very suburban characteristics that make the suburbs the most sought after housing typology in North America (Ruby, 2004). Such characteristics could be described as increased safety, better schools, more open space, single family housing, and a greater sense of privacy - especially private greenspace (Drukker, 2006).

DPZ suggest that, due to the sheer expanse of the suburban sprawl in some cities, what is needed is the introduction of urban foci that would act to serve the surrounding ring and balance the often dysfunctional 
nature of suburbia (DPZ, 2008). The insertion of density pockets is a compelling proposition for the creation of nodes and focal points within suburban neighbourhoods. However, Dodman explains in his report Urban Density and Climate Change (2009) that high urban densities do not necessarily add to a city's sustainability, but that densification can both contribute to and reduce the vulnerability of human populations, with the deciding factor being a city's ability to provide for its residents through appropriate infrastructure (Dodman, 2009). Over the past few decades, appropriate infrastructure entailed access to electrical, sewer, water networks and roads to buy goods and to move about. All of these were based on outside, often remote, sources; sources dependant on cheap energy to transport food, water, materials and energy from far off locations. In a world focused on building resilience in response to feedbacks, how will the term appropriate infrastructure evolve? fig. 1.3.11 productive median Unlike the previous reburbia submissions, the project Suburban Median Regeneration seeks to recreate the suburban street by introducing a range of resilient infrastructures.

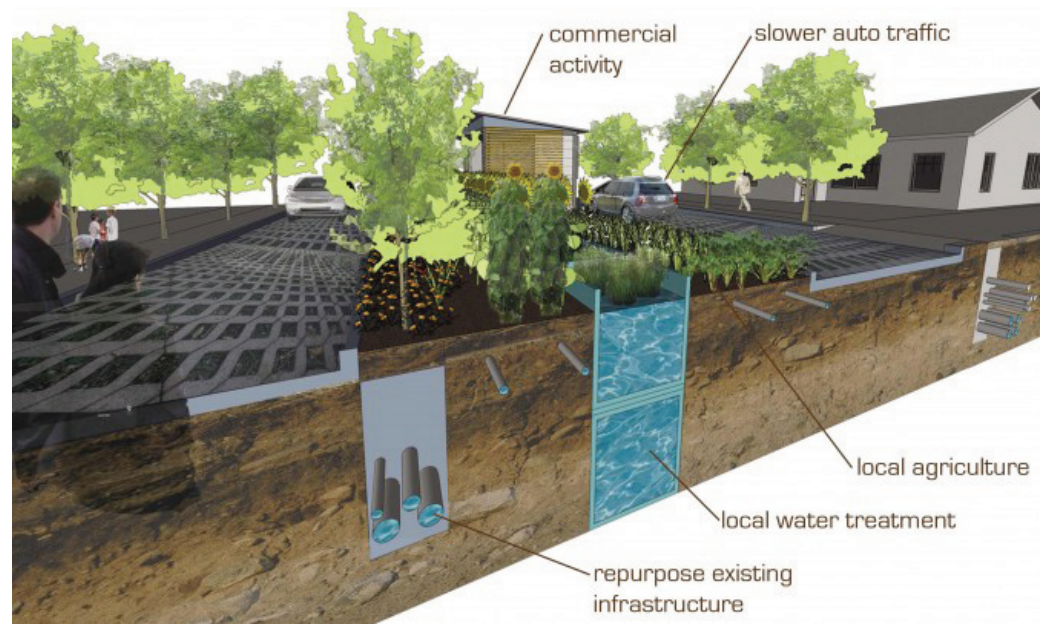

Landscape Urbanist's see the use of infrastructural systems in landscapes as the very ordering mechanisms of the urban field (Waldheim,2006) and believe that, like our roads and hydro corridors, urban landscapes which incorporate natural ecologies are an essential infrastructure for any city. Central to this thinking is the belief that within any urban landscape one should find the means and methods for cleaning the air and water, places dedicated to wildlife habitat, places that produce energy (solar, wind, or other) and places that facilitate ecological processes. Equal importance should be placed on the incorporation of diverse programs and activities based on human occupation ranging from bicycling to kayaking, playing soccer or ultimate frisbee to places for sunbathing or relaxation. It is 
this layering of natural ecologies, infrastructural systems and human appropriation that Landscape Urbanism posits as essential for urban landscapes.

The climate is right to renew Toronto's suburban inheritance, transforming it's suburban neighbourhoods into resilient assets of the city's durability. Concurrently, alternative living arrangements are needed that can serve Toronto's diverse residents, increasing population, and the obsolescence of its suburban housing stock. New neighbourhood typologies can be investigated that will add needed density to suburban Toronto, renewing its largest housing stock, while still respecting its inherent suburban qualities and appropriateness for becoming a resilient landscape - a productive, ecological, temporal and responsive terrain. 


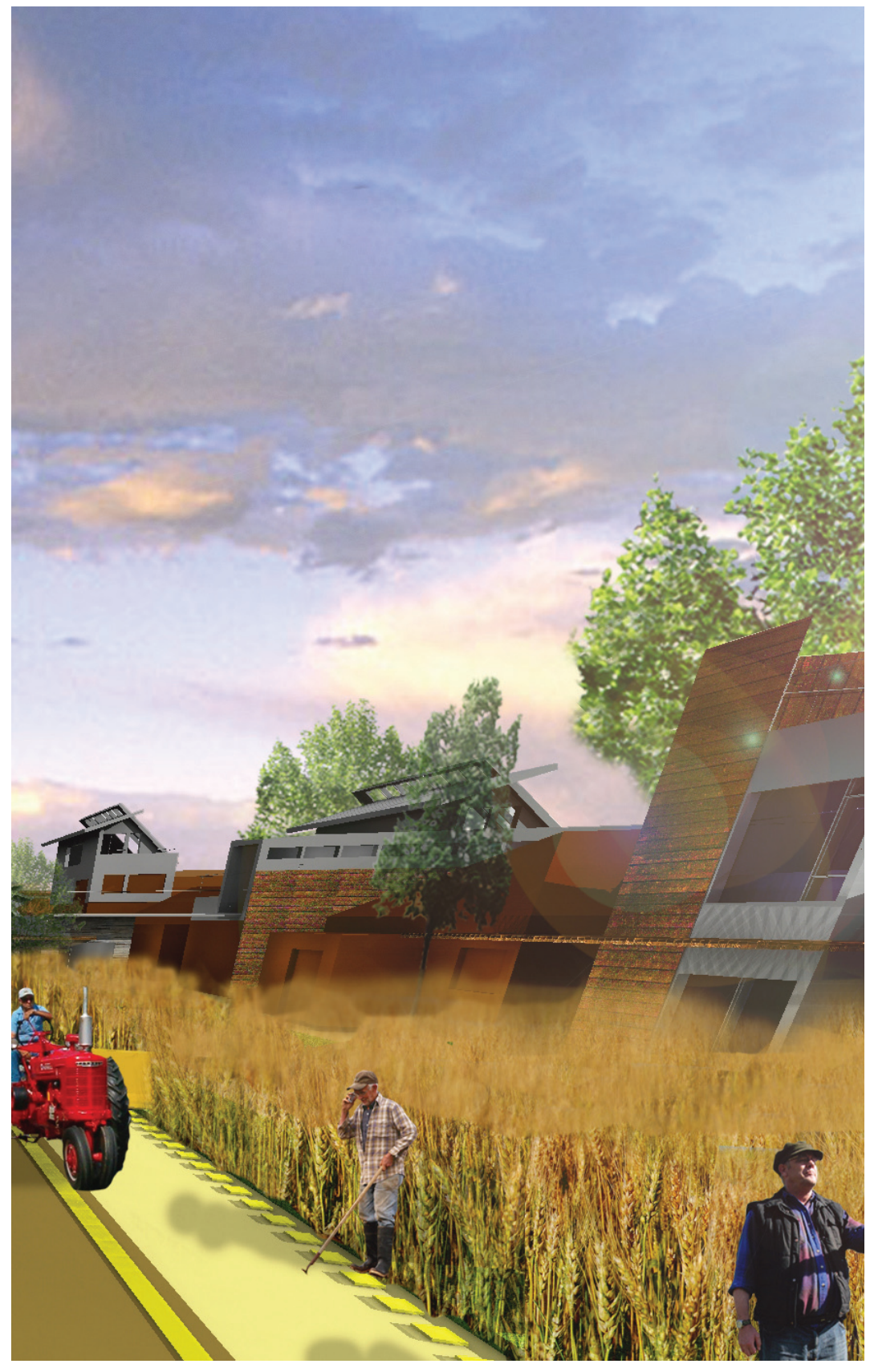

fig. 1.3.12 suburbs of Toronto as bread basket 


\section{2 lessons learned from precedents}




\section{$2.1 \quad$ suburban street}

2.1.1 mole hill One of the most successful co-operative housing projects in Canada, Mole Hill represents a community initiated street adaptation and housing retrofit in Vancouver BC. This project was designed and constructed under the supervision of $\mathrm{HBBH}$ architects, and in conjunction with S.R. McEwen Associated Architects, who worked collaboratively with the Mole Hill Housing Co-operative to achieve the community's vision. The neighbourhood came close to demolition in the 1990's as part of the city's plan to enlarge a neighbouring park. However, residents of the area questioned the need for more park space (as there were ample parks in the area) and proposed, instead, a renewal of the street and its heritage homes (Grdadolnik, 2005). Today, Mole Hill Housing Co-operative provides 168 low to medium income rental units (Grdadolnik, 2005). Midblock, a living lane connects the houses to a re-purposed street that accommodates a number of community activities. Most notable is the inclusion of edible landscapes within the streetscape, areas for water collection and reclamation, workshops accessible to the neighbourhoods, laundries, and the active street life and interactions that take place due to the pedestrian oriented setting. The project is in a constant state of change, with each year seeing new croppings, and new appropriations by various individuals and groups within the community. The project is also known for the comprehensive renovation of some of Vancouver's most noteworthy heritage homes, which included the incorporation of modern energy efficiency practices and the installation of geo-thermal heating.
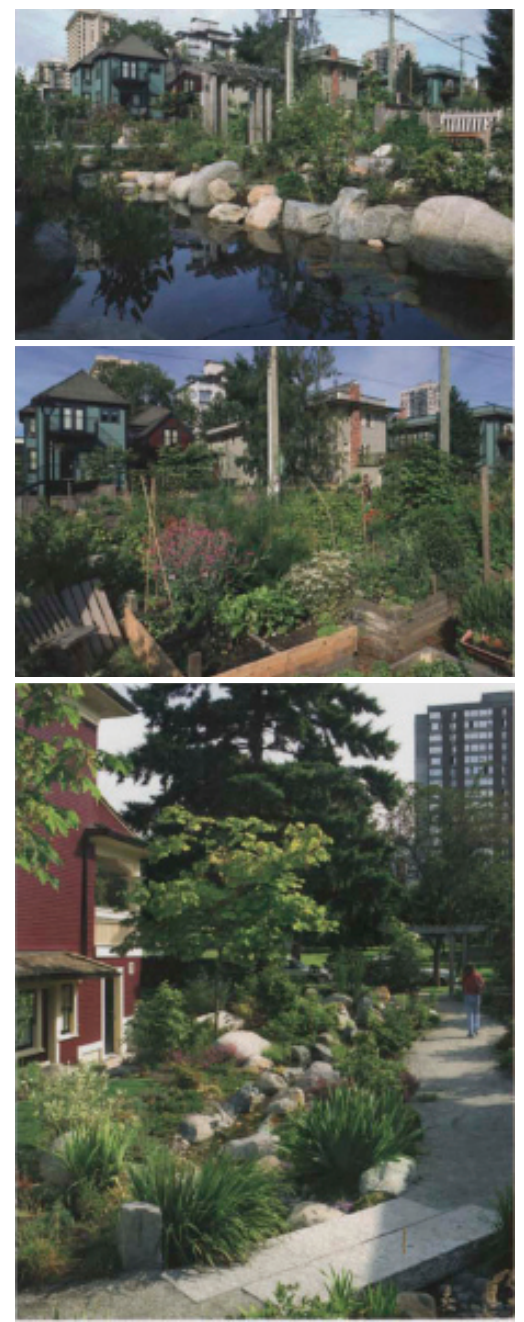

fig. 2.1.1 mole hill productivity Mole Hill's living street houses a number of productive activities including food production, water remediation, workshops and laundries. 


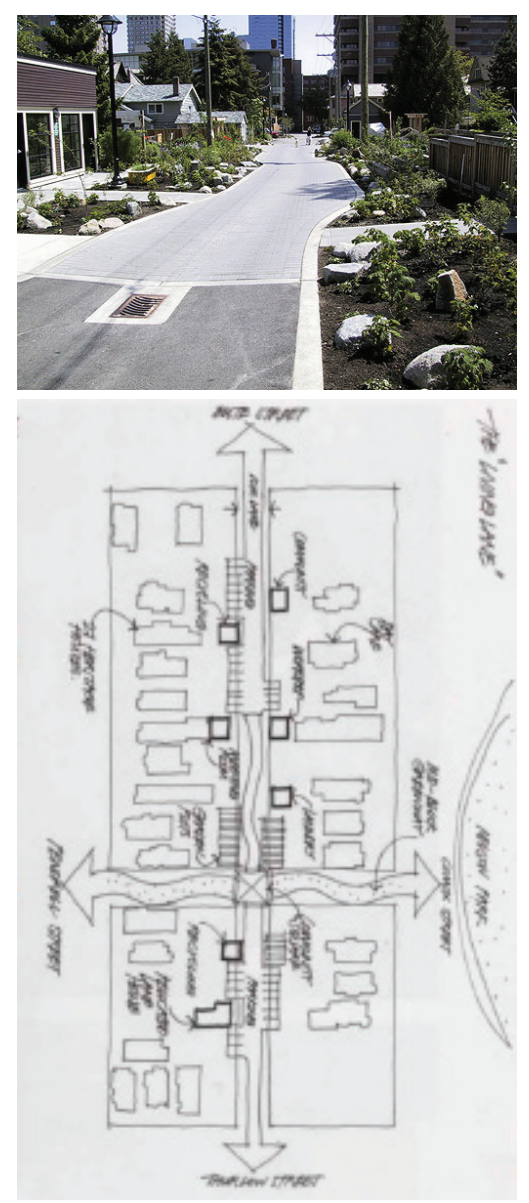

fig. 2.1.2 mole hill's living lane

fig. 2.1.3 mole hill's residential retrofits

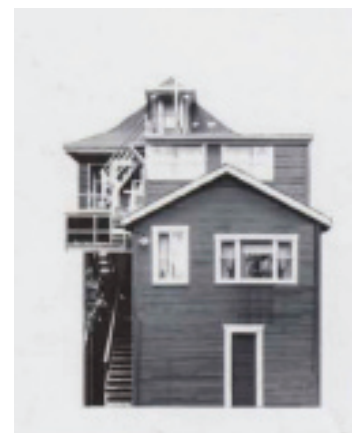

H1

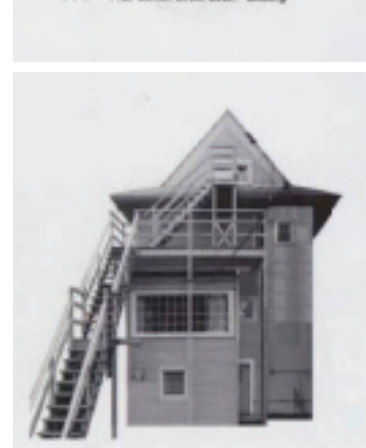

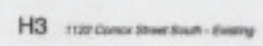

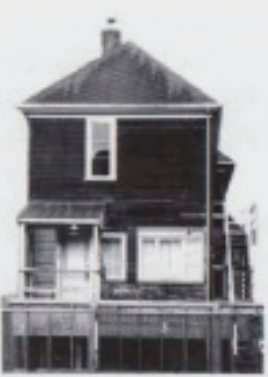

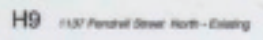

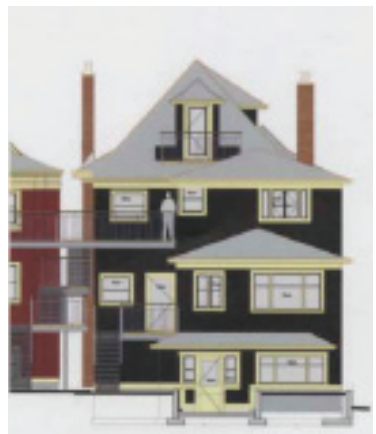

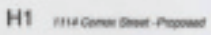

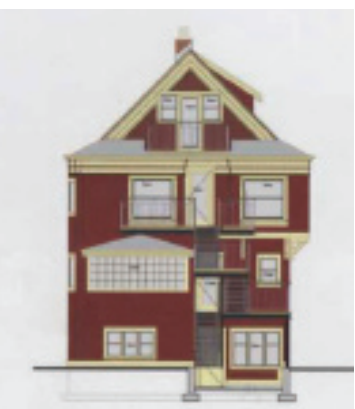

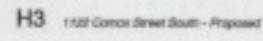

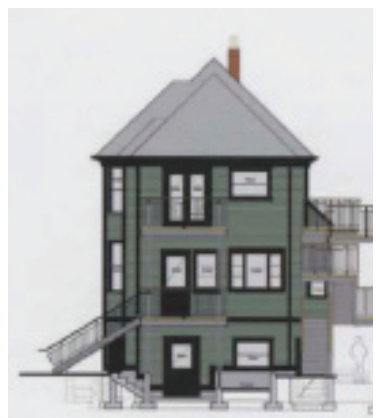

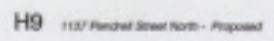


2.1.2 dutch woonerf A Dutch woonerf is defined as a shared street designed to be used by pedestrians, playing children, bicyclists and low speed vehicles; a public place for residents instead of singlepurpose conduits for automobiles. Perhaps the earliest incarnation of the woonerf is depicted in Johannes Vermeer's $17^{\text {th }}$ century painting Straatje. The painting shows an old lady repairing clothes in a doorway while keeping an eye on the children at play in front of the house. A semi-private area, the stoep, provides a safe place on the pavement for the boy to play within (Schepel, 2005). At the time of Vermeer's painting, such a street scene was common. It wasn't until the 1960 's and $70^{\prime}$ s, in response to congested traffic and the lack of pedestrian consideration, that the word Woonerf came into popular use. Woonerf can be translated as the residential yard or the living yard and is applied as shared streets in Germany, no car areas in Denmark and Sweden, and home zones in England. Woonerf's are also used in high-density countries such as Israel and Japan (Panayotova, 2002). They are largely known for their success in giving the street back to pedestrians, with pedestrians having the freedom to occupy the entire width of the road as opposed to the narrow sidewalks that we see in most North American cities. Residents are free to communicate, play, and mingle anywhere on the street, which encourages outdoor activities to occur on the street thus creating a safer environment. Since the beginning of the 1990 's, over 2700 Dutch streets were converted into woonerven (the plural of woonerf) which has led to a 50 percent reduction of street related injuries (Panayotova, 2002).

In order to establish a woonerf in the Netherlands 60 percent of the neighbourhood residents must give their approval, which is crucial as residents that give their consent to the newly configured streetscape

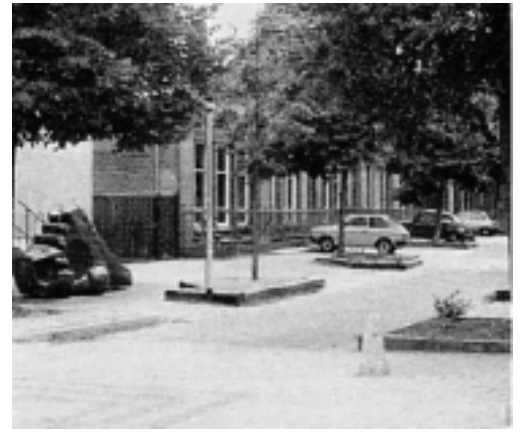

fig. 2.1.4 1970's dutch woonerf

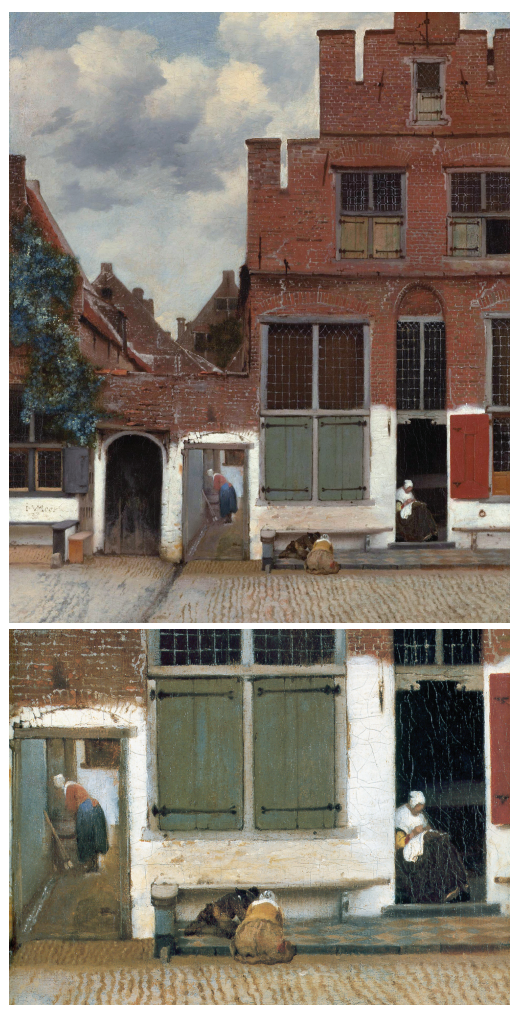

fig. 2.1.5 Vermeer's Straatje 


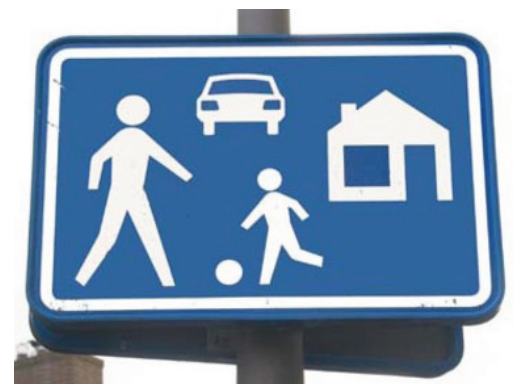

fig. 2.1.6 the living street, the living yard

fig. 2.1.7 pedestrian street The Dutch woonerf is designed to accomodate the needs of pedestrians and bicyclists primarily, and automobiles secondarily. are more likely to maintain it and enforce the living yard regulations (Panayotova,2002). In Denmark, each household contributes a sum of money comparable to the price of a new refrigerator in order to fund the formation of the woonerf (Panayotova, 2002). In many Dutch examples, this has given residents the sense of territorial ownership over the woonerf, leading to a continuously maintained and managed collective residential landscape. These collective landscapes often lead to greater communication and integration of uses, increased interactions, and enhanced environments for the residents of the neighbourhood (Panayotova, 2002). This has certainly been the case for the Mole Hill Co-operative Housing precedent discussed earlier.
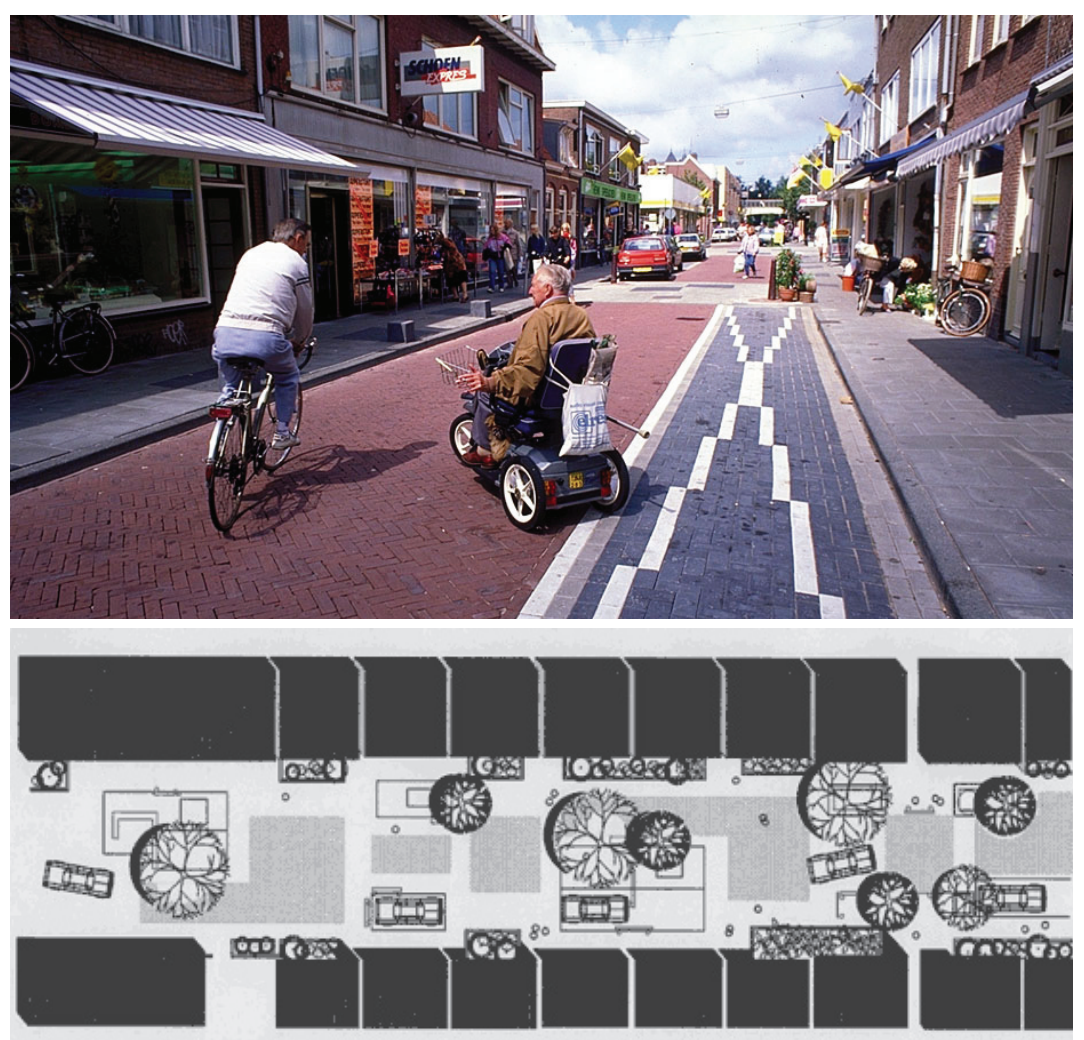


\section{2 suburban space}

\subsection{1 fabric approach In Suburban Space (2002), Renee Chow} examines the role of the architect in the definition of the suburban environment. Through a series of case studies, mappings, and analysis Chow demonstrates the physical distinction between a volumetricbased physical environment and a fabric approach. Volumetric, Chow explains, is the disparate and disconnected arrangement of objects on a plane; a landscape defined by separated volumes, each standing independently of one another. Chow believes this is largely the way suburbs have been planned and that such an approach has led to the perception of the suburbs as placeless and homogeneous, as both wasted land and resources. Seeing the suburbs as a fabric a continuous arrangement of spaces in which we reside and through which we move - allows designers to describe relations not just within but among the houses (Chow, 2002). Chow is arguing for a reconsideration of suburban space, one in which architects have a larger role to play in describing the potential of these suburban spaces to prompt interactions, community engagement and a sense of place or how Chow states it a weaving of people to places, houses to setting, indoors to outdoors.

Many of her mapping exercises speak for themselves. Most notable is her comparison between the Sachs Apartment (San Francisco) and Levittown (New York) housing typologies, showing the treatment of access as being critical in a neighbourhood focused on interactions and connectedness. In addition, Chow's mapping of claimed and unclaimed spaces sheds light on the un-inhabitability of the suburban street and suggests a more involved organization of private, semiprivate and public spaces will lead to richer environments.

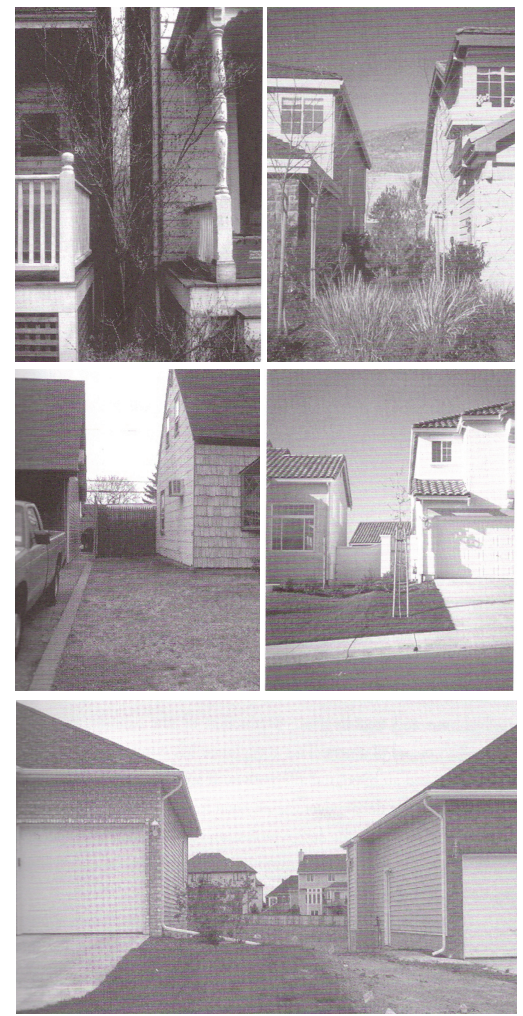

fig. 2.2.1 separations Chow's photo series documents the boundaries and separations between detached housing typologies and argues for a more sophisticated approach to suburban planning. 

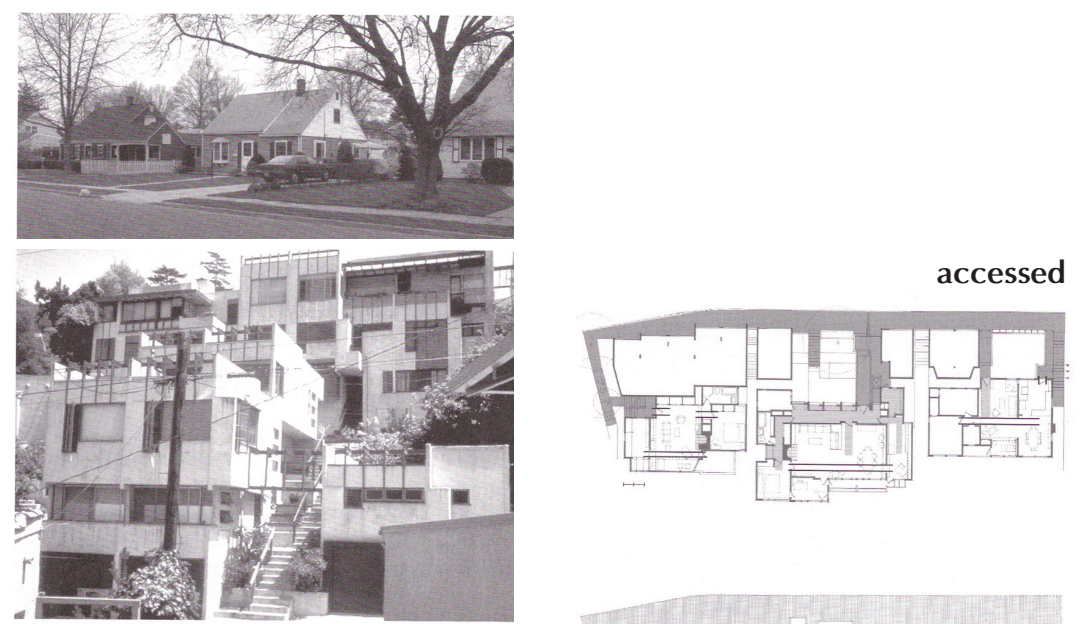

claimed/unclaimed

fig. 2.2.2 a comparison between Levittown and Sachs apartments

fig. 2.2.3 claimed and unclaimed, accessed Shown is Chow's diagrams investigating the access routes and the claimed areas of both the Levittown housing development and the Sachs Apartment complex. Access in the Sachs Apartments is treated with an integrated approach, with multiple shared entranceways as opposed to individual entrances in the Levittown model. Likewise claimed/unclaimed territory is more complex and diverse in the Sachs Apartment complex than it is in the Levittown model.
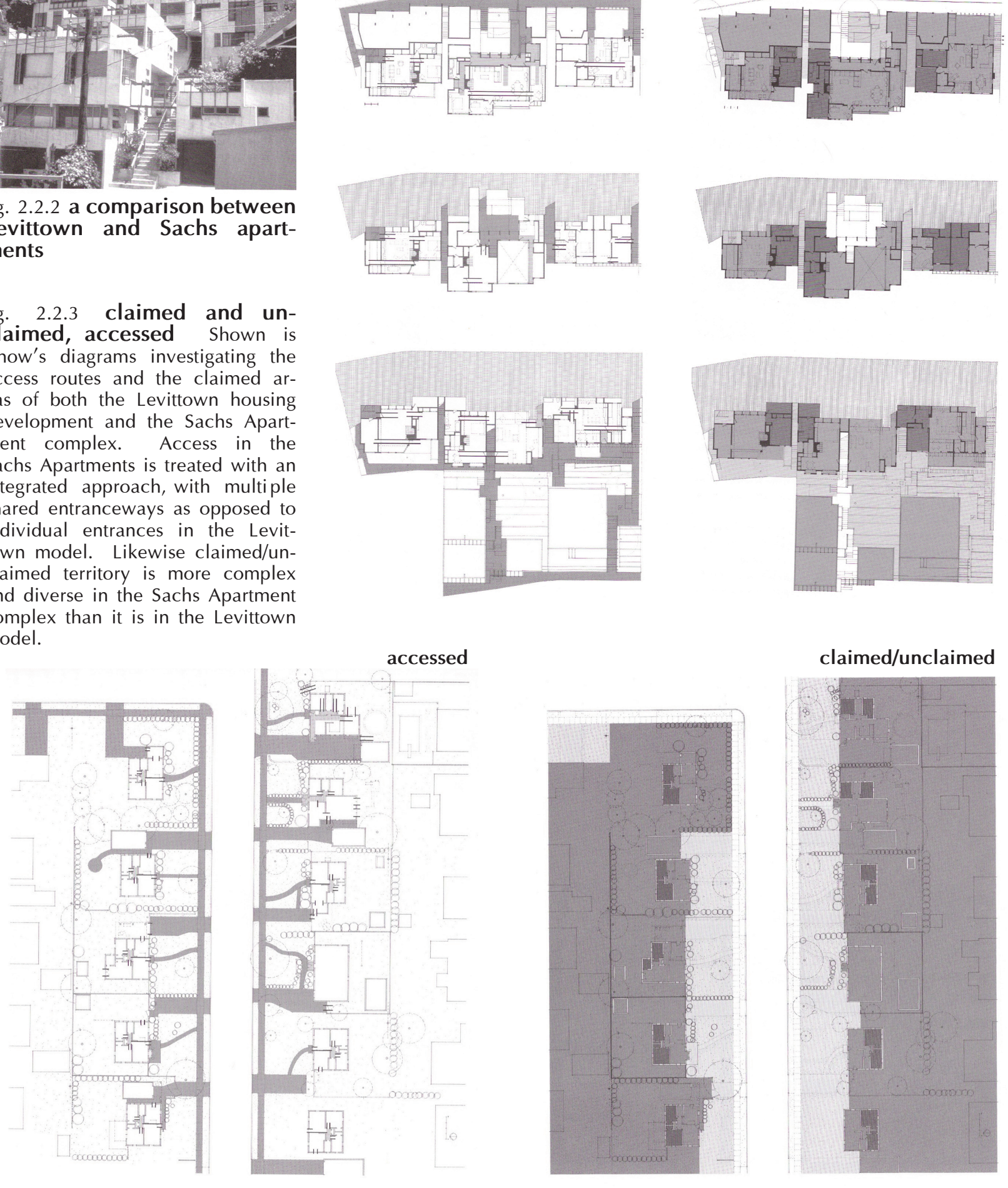


\subsection{2 village homes, capri court Although Renee Chow uses} a rather dense apartment block (Sachs Apartment) as an example of the fabric approach, there are a number of appropriate suburban examples of such woven spaces worth noting. Village Homes and Capri Court, located respectively in Davis and Clovis, California, both were planned as pedestrian oriented, community based housing developments. Most notable is the parallel between their treatment of the entrance and that of the Sachs Apartments in Chow's analysis mentioned earlier. Shared access between four detached homes creates a greater sense of interaction and cohesion in the Capri Court neighbourhood. Shared access is a major factor in creating rich environments and interactivity in housing developments. In fact, the average resident of Village Homes knows 42 people in his or her neighbourhood, while in surrounding areas the comparable figure is 17 (Drukker, 2006). In addition, 80 percent of residents regularly participate in various neighbourhood activities. Annual household utility bills range from 33 - 50 percent lower than those in surrounding neighbourhoods (Drukker, 2006). This can largely be attributed to the shared network of utilities, such as solar oriented planting, natural drainage systems such as bio-swales and wetlands, and extensive edible landscaping as well as an energy conscious community. In addition to the cost savings and sense of community generated by the sustainable design, Village Homes quickly became popular in the marketplace, selling at a faster rate than conventional developments in the Davis area (Drukker, 2006).

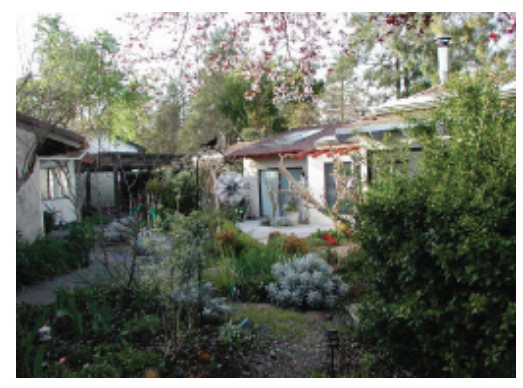

fig. 2.2.4 village homes Village Homes is known for the incorporation of natural drainage systems such as bio-swales and wetlands into the community landscape. 


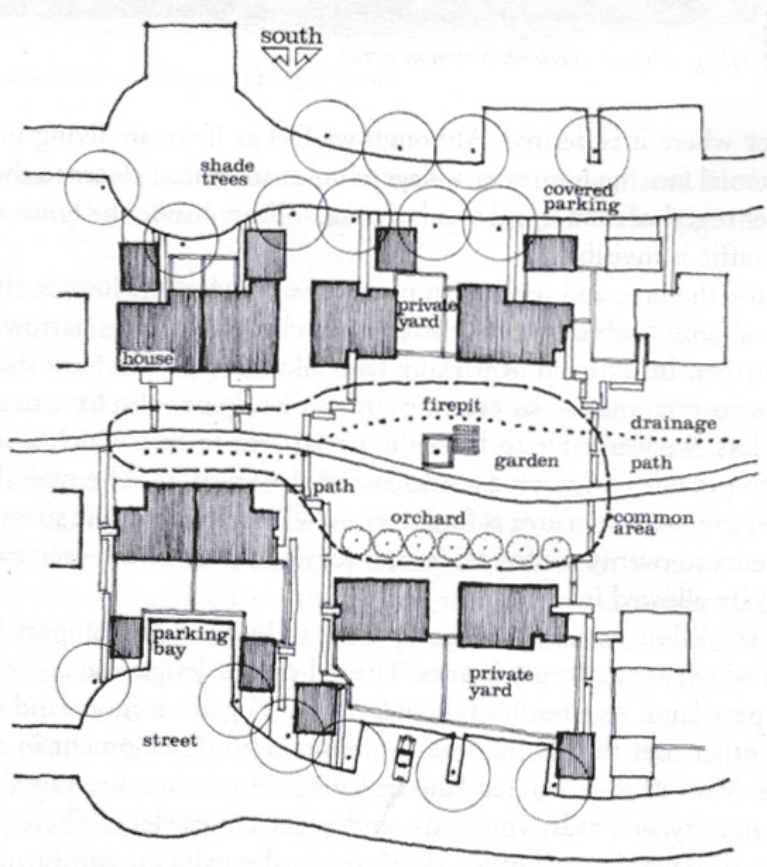

fig. 2.2.5 integrated space Village Homes was conceived from the beginning as an integrated, community oriented housing development, with planned shared entranceways, community firepits, gardens, orchards and natural landscape features.
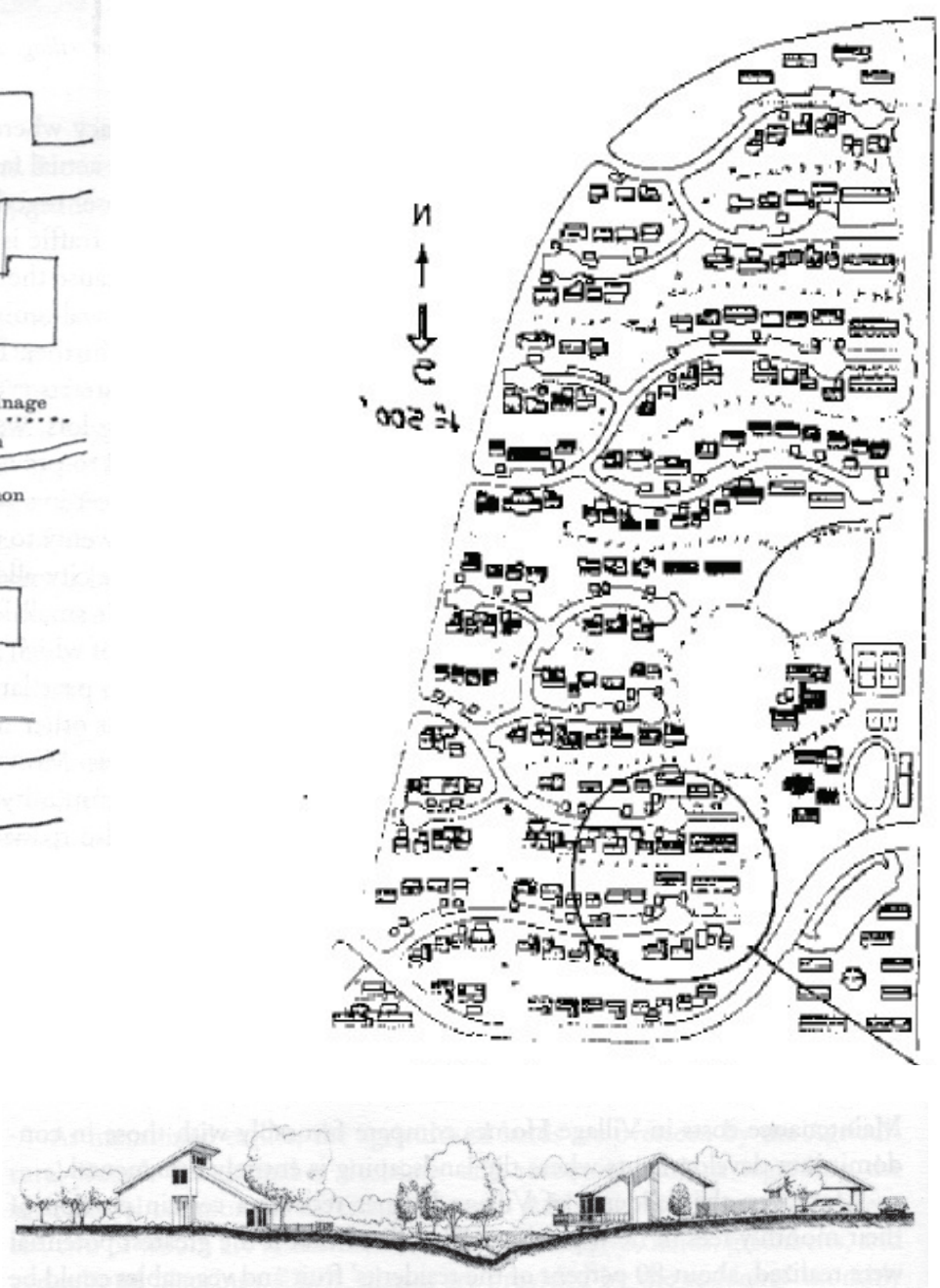

fig. 2.2.6 capri court Capri Court was also planned as an integrated neighbourhood, focusing on the orientation of the houses. Four houses share one entranceway, which has been proven to increase social interaction and community participation in the neighbourhood.

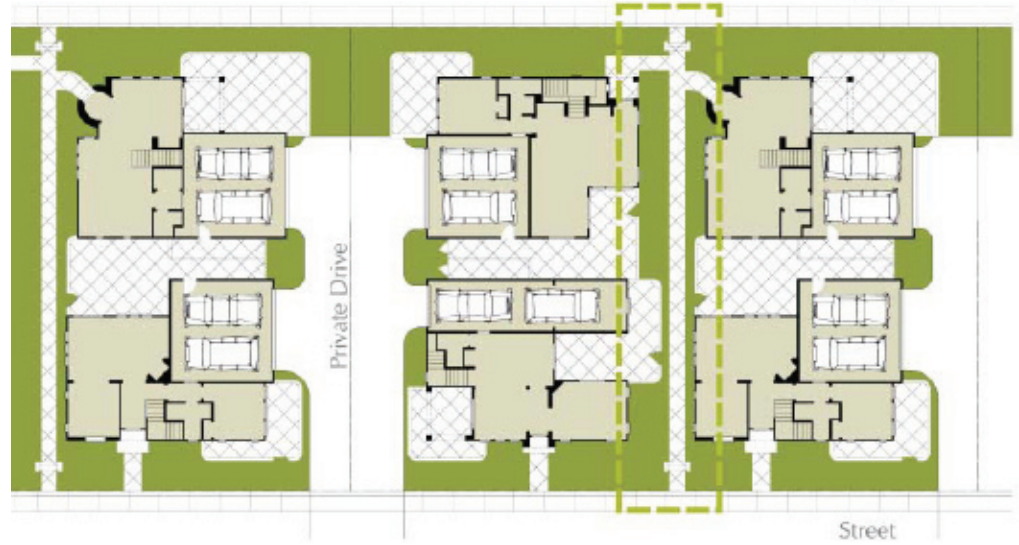

Capri Court Cluster

Single Family Detached Home

[] Garden Court with Trail

Source: Wathen-Castanos, Inc., October 2004 


\section{3 suburban change}

\subsection{1 the recalibration of first ring suburbs The Recalibration}

of First Ring Suburbs, which began as an inquiry at the Design Center for the American Urban Landscape, seeks to link neighbourhood change to regional change by exploring a series of products and strategies that can be added to an existing suburban development to transform it into an eco-neighbourhood. At the heart of this project is the premise that the revitalization of existing neighbourhoods can play a pivotal role in curbing urban sprawl and reclaiming natural resources (Tanzer, 2007). The project explores 4 housing models The Storage House, The Appliance House, The Garden House, and The Neighbourly House - each with its own set of potential additions and renovations. The housing types present possible strategies, products and resources that could be implemented by homeowners to transform their home, lot and neighbourhood as a series of incremental changes over time (Tanzer, 2007). The most notable aspect of this project is the creation of a website that provides links to resources, products, and service providers/consultants. It is posited that Home Depot (the one-stop, do-it-yourself super store) needs a corollary in the form of a one-stop information source that makes it easy for homeowners to choose which changes work for them, and how to find the people and products to make it happen. While the concept is thoughtful, and the project presents much potential, many of the proposed products and additions are common or inconsequential (ex. Linen storage, internet access, additional outlets). The creation of distinct typologies and the accessibility to options for bottom-up, small scale suburban renewal is where this project holds the most promise.
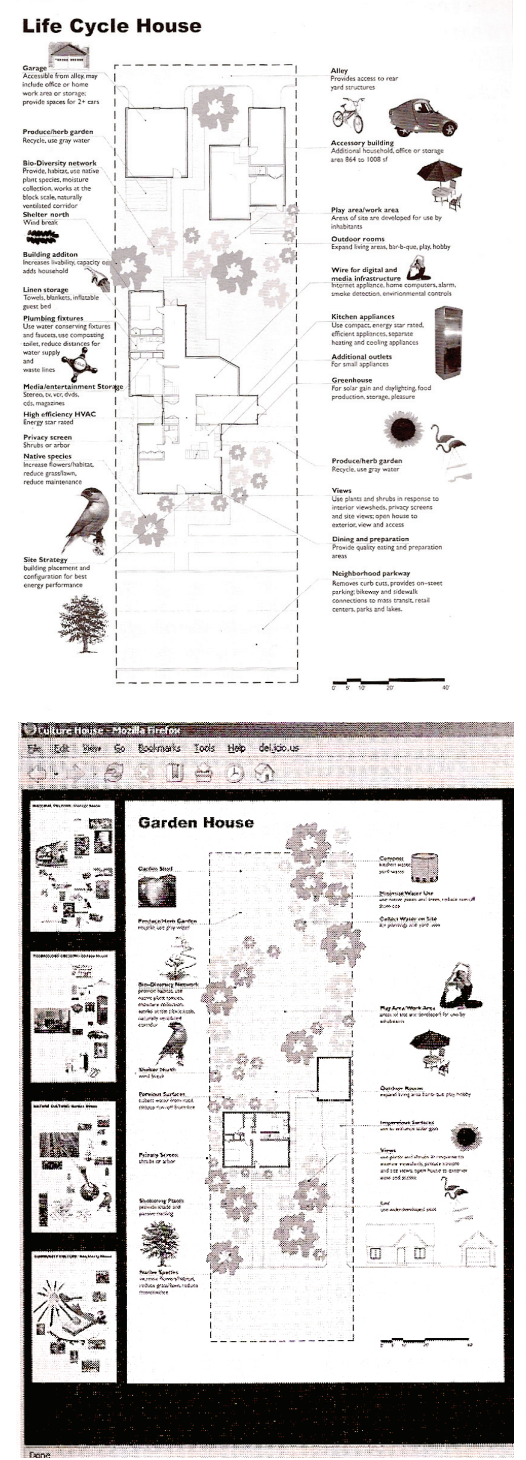

fig. 2.3.1 online resources 
fig. 2.3.2 recalibration of the suburbs Shown is the re-imagining of the backyard into an communal alley, shared by residents of the neighbourhood and access lane for backyard grannyflats.

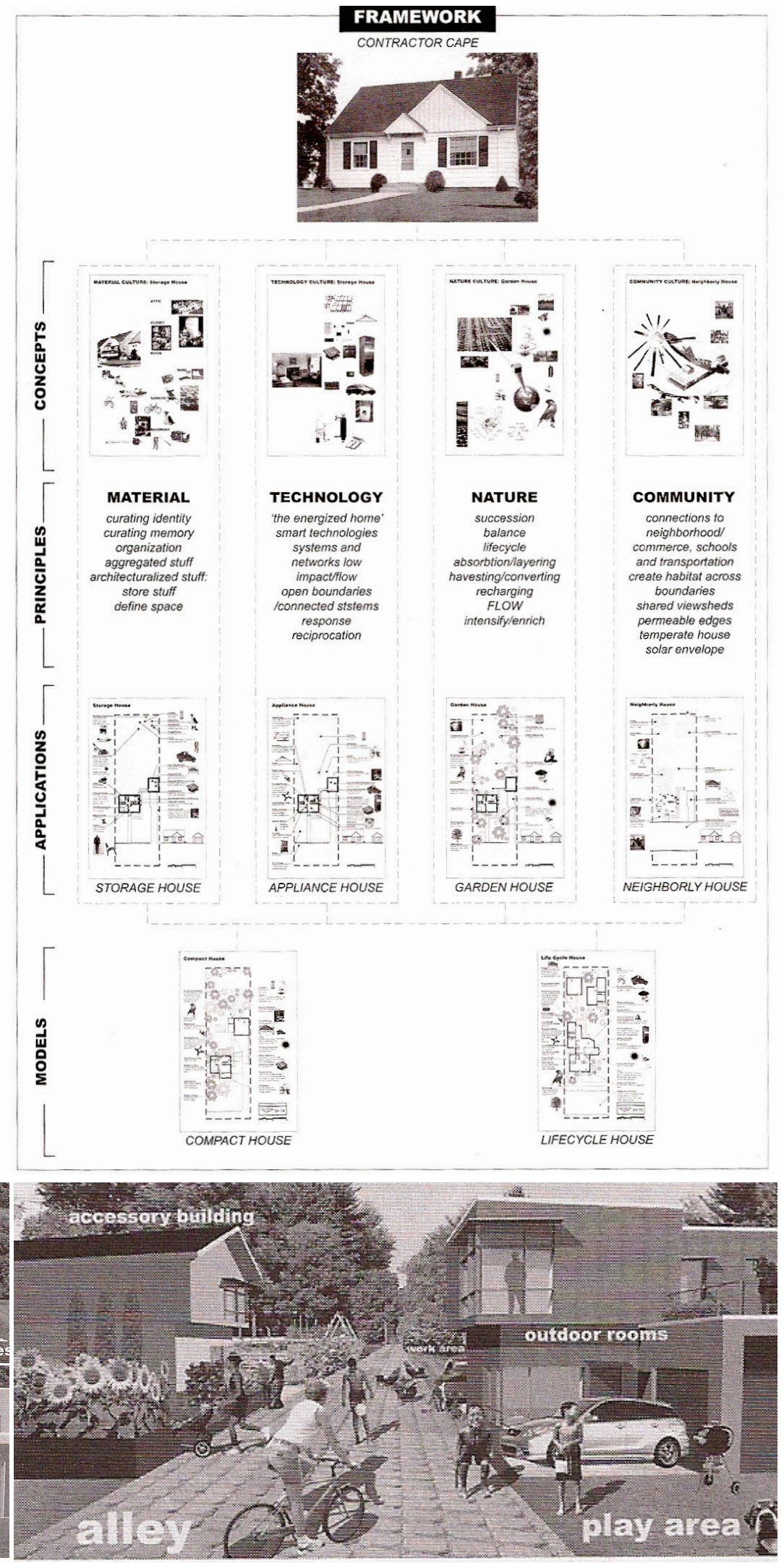


2.3.2 parc de la villette While not a suburban precedent, the 1982 design competition for Parc de la Villette produced noteworthy projects that focused on infrastructural networks accommodating undefined future programs. In their proposals for Parc de la Villette, Rem Koolhaas and Bernard Tschumi, who in turn drew on the timecentered work of Cedric Price and Archigram (Shane, 2004), proposed infrastructural landscapes that allow for adaptable and open ended projects. The projects focused on the construction of a horizontal field, a prepared grounds, of infrastructure that would accommodate a multitude of urban activities, planned and unplanned, imagined and unimagined - a strategically organized infrastructure that would support an indeterminate and unknowable range of future uses over time (Almy, 2007). These prepared grounds were flexible and open, allowing the ad hoc emergence of performative social patterns and group alliances that would eventually colonize such surfaces in provisional yet deeply significant ways (Shane, 2004). As a precedent study in planning for an uncertain future, Koolhaas' and Tschumi's treatment of landscape as a temporal, flexible, and open ended entity is note worthy.

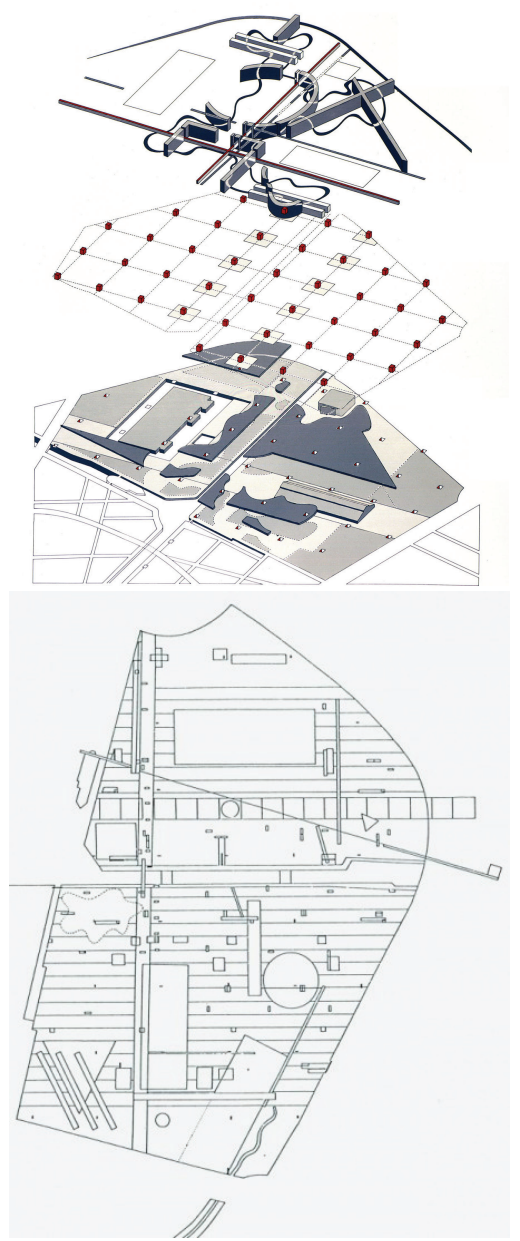

fig. 2.3.3 Tschumi's and Koolhaas' vision for parc de la villette In 1982 both Bernard Tschumi and Rem Koolhaas submitted proposals looking at time centered design processes that would allow the park to develop over time. 


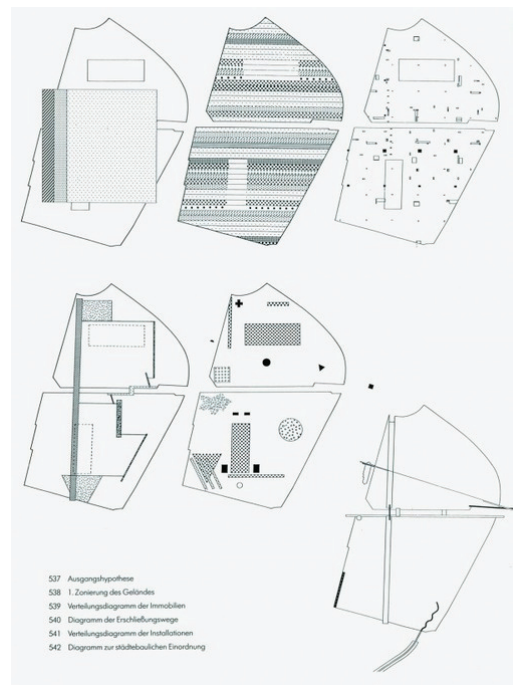

fig. 2.3.4 Koolhaas' layered approach fig. 2.3.5 conceptual skecthes conceptual sketches of Tschumi's vision for Parc de la Villette.
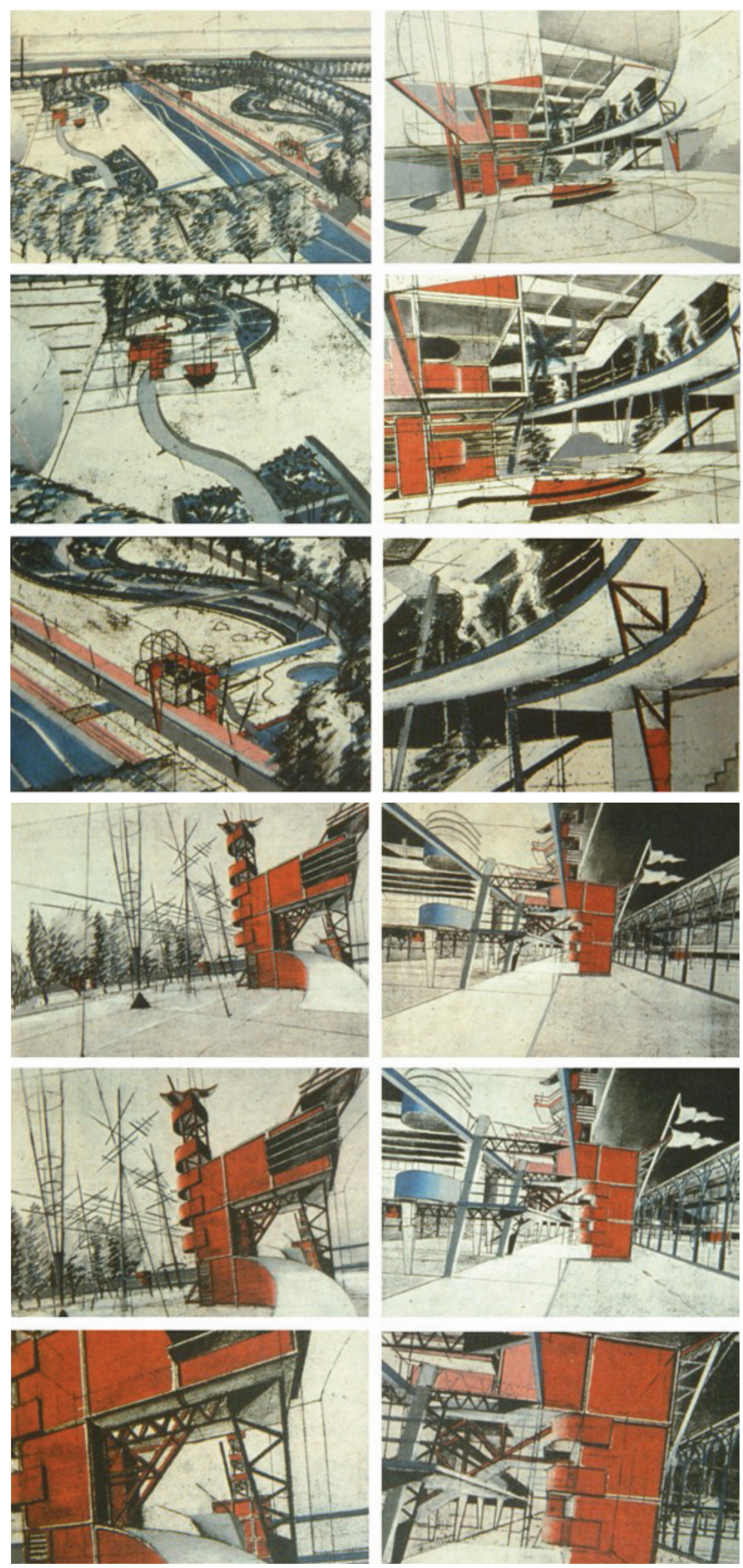


\subsection{3 learning from Tijuana Estudio Teddy Cruz, an architectural} firm based out of San Diego, has been producing persuasive designs for the transformation of the American suburb based on their studies of Tijuana slums. Cruz has observed that developers in Tijuana have been building entire neighbourhoods of generic 400 sq. foot houses - a miniature version of suburban North America - that have been quickly retrofitted by the tenants (Ouroussoff, 2008). Informal businesses like mechanics shops and taco stands quickly appeared in front lawns and between houses, transforming them into highly layered spaces (Ouroussoff, 2008). Within only a few years, these suburban neighbourhoods have been inhabited with grocery stores, repair shops and food stalls; new floors have been added, single family homes have been joined together to house extended families, and many of the beige buildings have been repainted in bright colours (Peterson, 2006). Once these transformations have occurred, they are protected from demolition under Mexican law and the government is eventually obliged to provide plumbing, electricity and roads to serve these newly configured neighbourhoods (Peterson, 2006).

Cruz sees this process as a far more flexible and democratic form of urban development than what is present in North American suburbs today (Peterson, 2006). He sees the seeds of a vibrant social and architectural model, one that could be harnessed to stimulate the static, uniform suburban communities found just across the border (Ouroussoff,2008). Estudio Teddy Cruz have been working on projects that look at applying those lessons to the design of San Diegos suburbs, projects that have grown to include community gardens, playgrounds, outdoor amphitheatres, co-operative grocery stores and

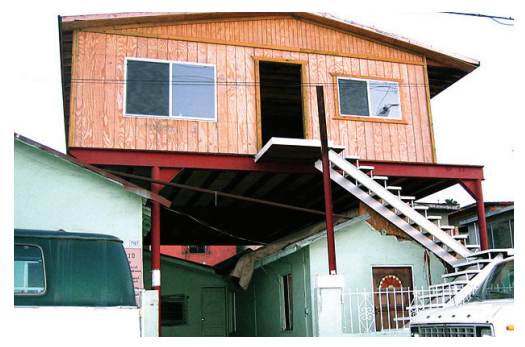

fig. 2.3.6 Tijuana suburban renewal A suburban development in Tijuana experiences the addition of ad hoc buildings to it's built environment.

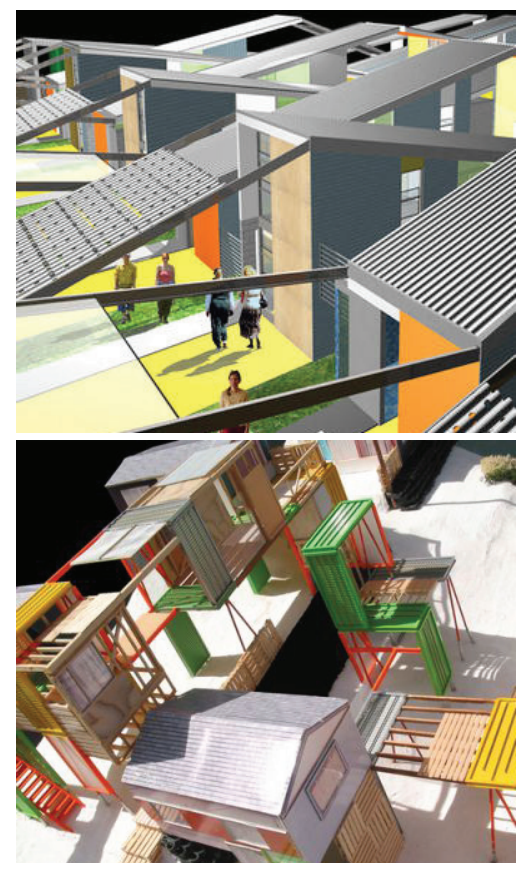

fig. 2.3.7 estudio Teddy Cruz conceptual models 
incubator spaces that could be used for arts or job-training purposes (Ouroussoff, 2008).

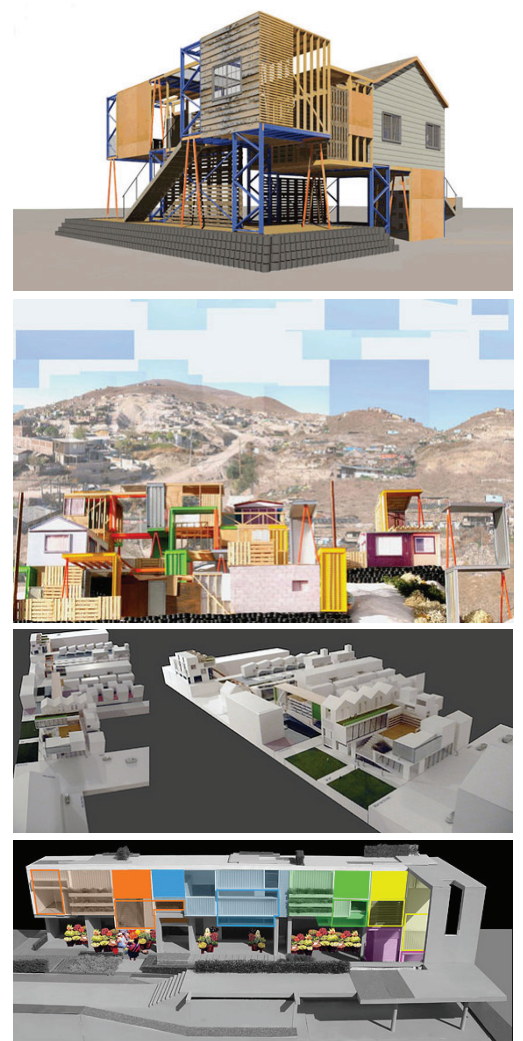

figs. 2.3.8, 2.3.9, 2.3.10 estudio Teddy Cruz san diego proposal Shown is various concept models for the implementation of the lessons learned from Tijuana suburban adaptations.

To go forward with the project, Estudio Teddy Cruz launched an unrestrained campaign to change the city of San Diegos zoning bylaws, seeking ways to endorse mixed-use communities and an urban fabric in which structures blend freely into one another (Peterson, 2006). The San Diego City Council have since approved his proposed developments, and changes to the zoning by-laws have been made.
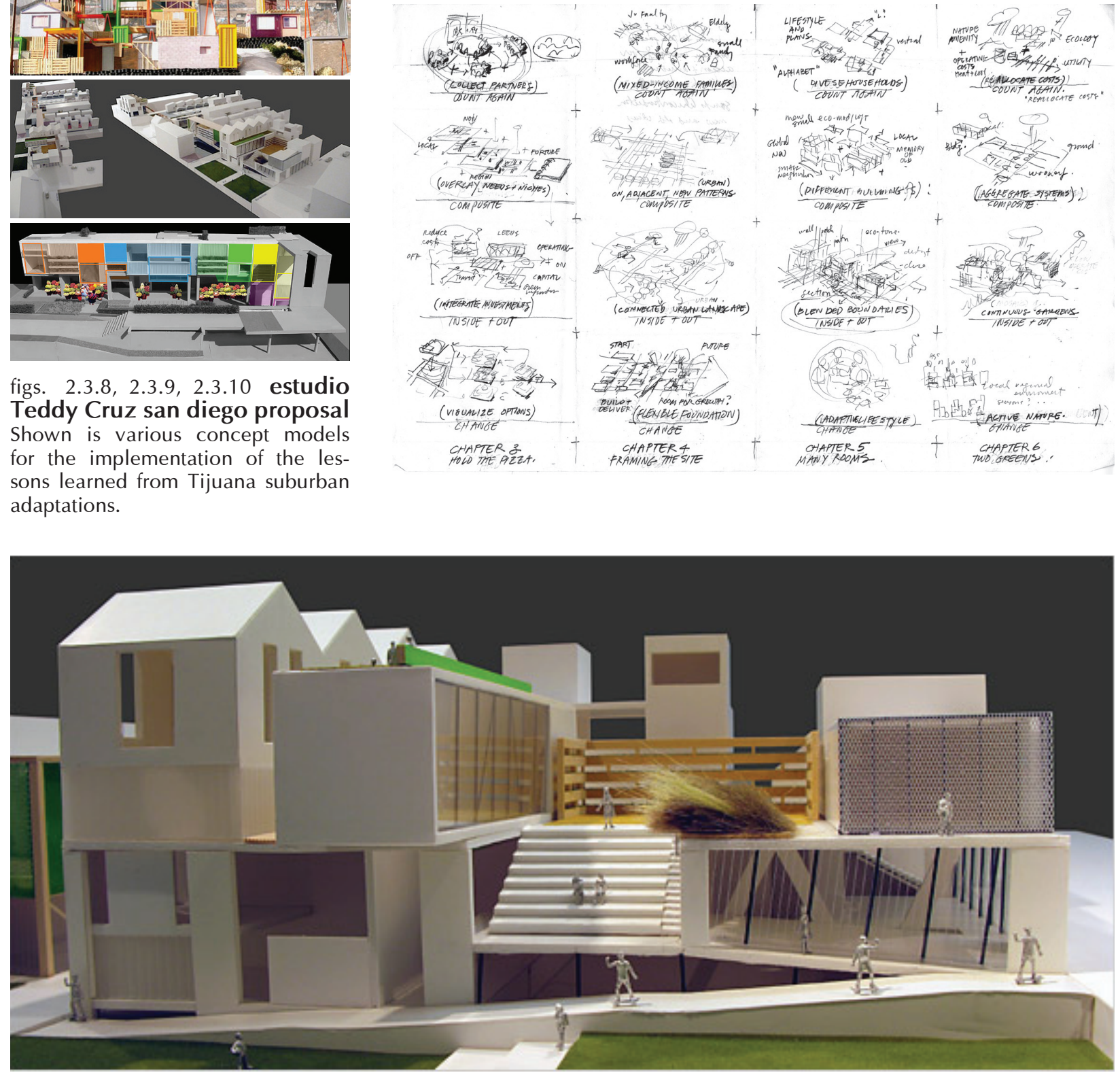
2.4 principles gleaned The case studies presented in the section lessons learned from precedents represent a wide range of potentials, strategies, and approaches that might as a whole, or separately, begin to inform the application of resilience building in Toronto's suburban neighbourhoods. The principles that are gleaned from these precedents could be summarized as follows:

Suburban Renewal will include:

Suburban Street - A connective street, a pedestrian corridor with portions suitable for appropriation and resident involvement, interactivity and play; street activity, less rigid formation, production of food, clean water, employment opportunities, retail activities, house renovations

Suburban Space - A physical redefinition that encourages interaction, activities, a sense of place, and a rich environment; a diversity of spatial arrangements woven into a connected fabric. Spatial redefinition of the neighbourhood to add diversity, cohesion, and interwoven spaces; neighbourhood communication and participation

Suburban Change - A proposed process for changes to occur over time,organically and dispatched as residents, homeowners, and communities respond to future uncertainties; allowing for incremental change to occur, the emergence of themes and identities, fixed and unfixed infrastructures, regulations that allow for neighbourhood change based on feedback loops 


\section{3 neighbourhood analysis}


3.1 mapping A series of mapping exercises were undertaken in order to shed light on the current condition of suburban Toronto, and to situate the design explorations undertaken in the next chapter. The neighbourhood known as Knob Hill was selected as a representation of a typical inner ring suburban neighbourhood in the city of Toronto. Knob Hill is located between four major arterials of Toronto, Lawrence and Eglinton avenues to the North and South; McCowen Road and Midland Avenue to the East and West. The mapping exercises undertaken include a walking exploration of the site, documented in photographic sequence; diagrammatic mappings exploring the contradictory nature of the suburban landscape; a series of land availability surveys that show the immense land available for re-appropriation; a series of walking-distance mappings that indicate the inaccessibility of Knob Hill to healthy food, employment, and public transport - even with official plans for densifying the arterials; and mapping exercises that demonstrate the land required for a number of critical resiliency building measures such as water storage, food production, and energy generation. This final exercise speaks to the potential for Toronto's suburbs to work in conjunction with denser arterials; a way of reducing the load of the city by linking productive lower density neighbourhoods with the higher density arterials proposed in Toronto's official plan.

The following mapping exercises began as a form of research undertaken to better understand suburban Toronto. They also point the way to the vital role that suburban Toronto has to play in a resilient future. 


\section{opposite}

fig. 3.1.1 walking map of Knob Hill The neighbourhood of Knob Hill was explored during multiple site visits. One route was selected (see opposite) and documented in a series of photographs and observations

fig. 3.1.2 photo series of Knob Hill walking exercise The following photo series documents the primary and immediate observations of the Knob Hill site visits. This photo series gives a sense of the neighbourhood, its landscape and buildings and begins to indicate the potential of the site for resilience building due to the sheer amount of land available.

Boundaries - no interface between street and yard, house and yard, neighbourhood and city

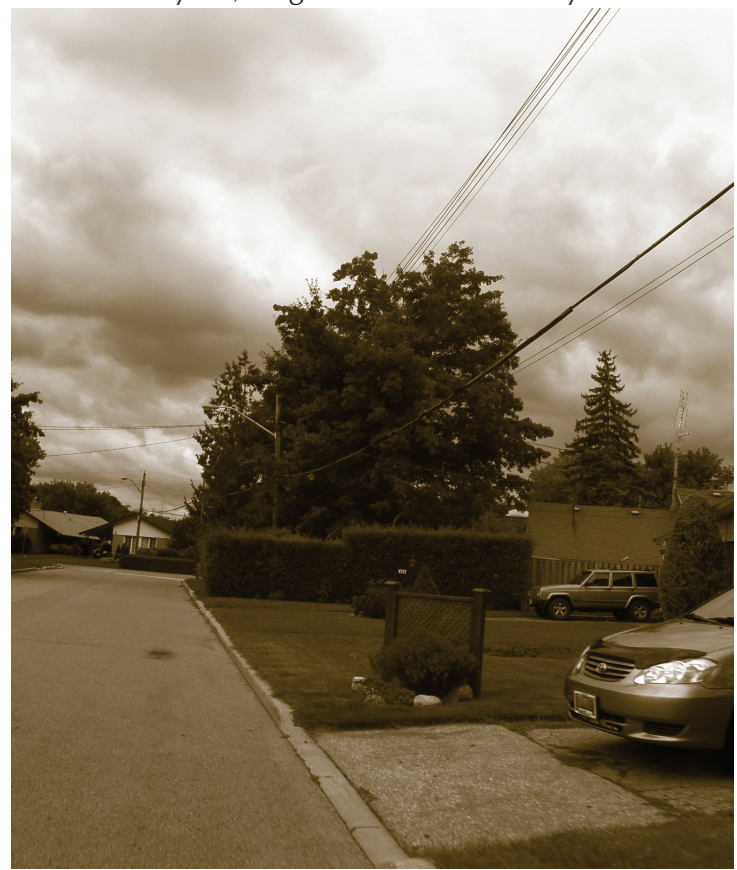

Separations - single family, detached housing typologies define the neighbourhood
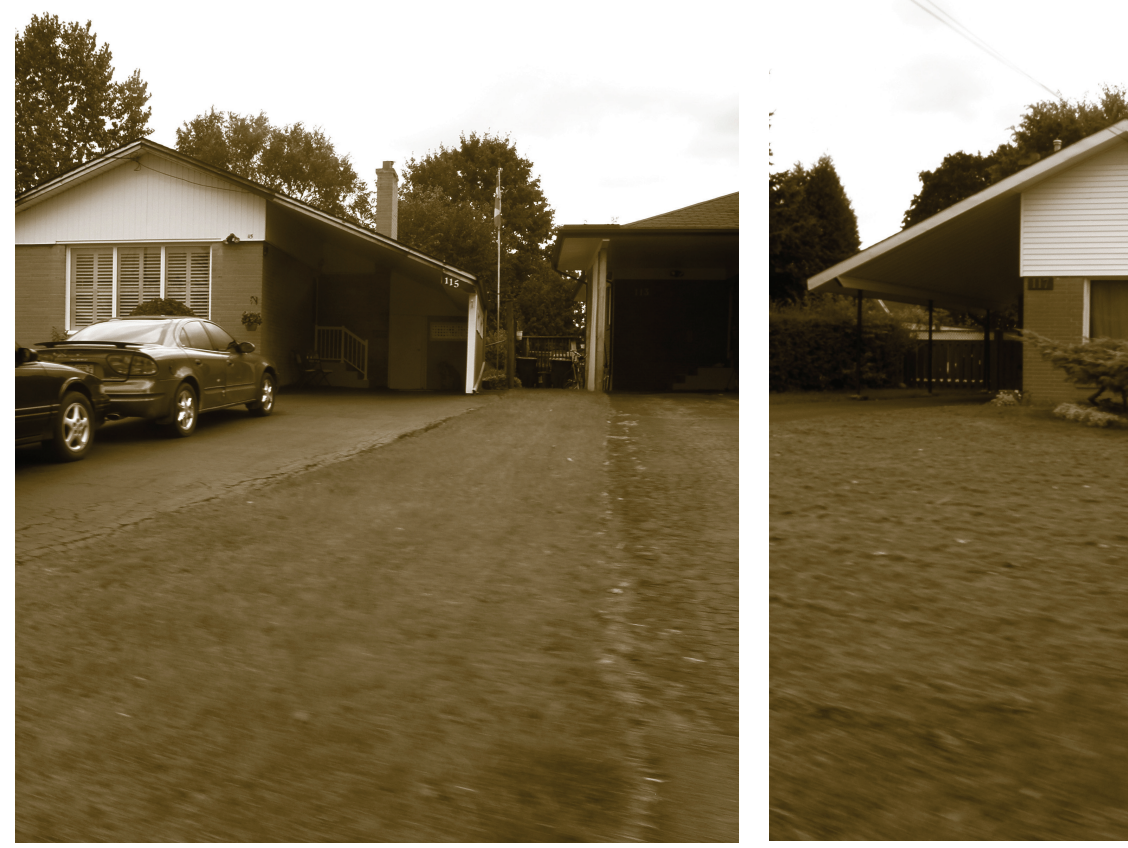

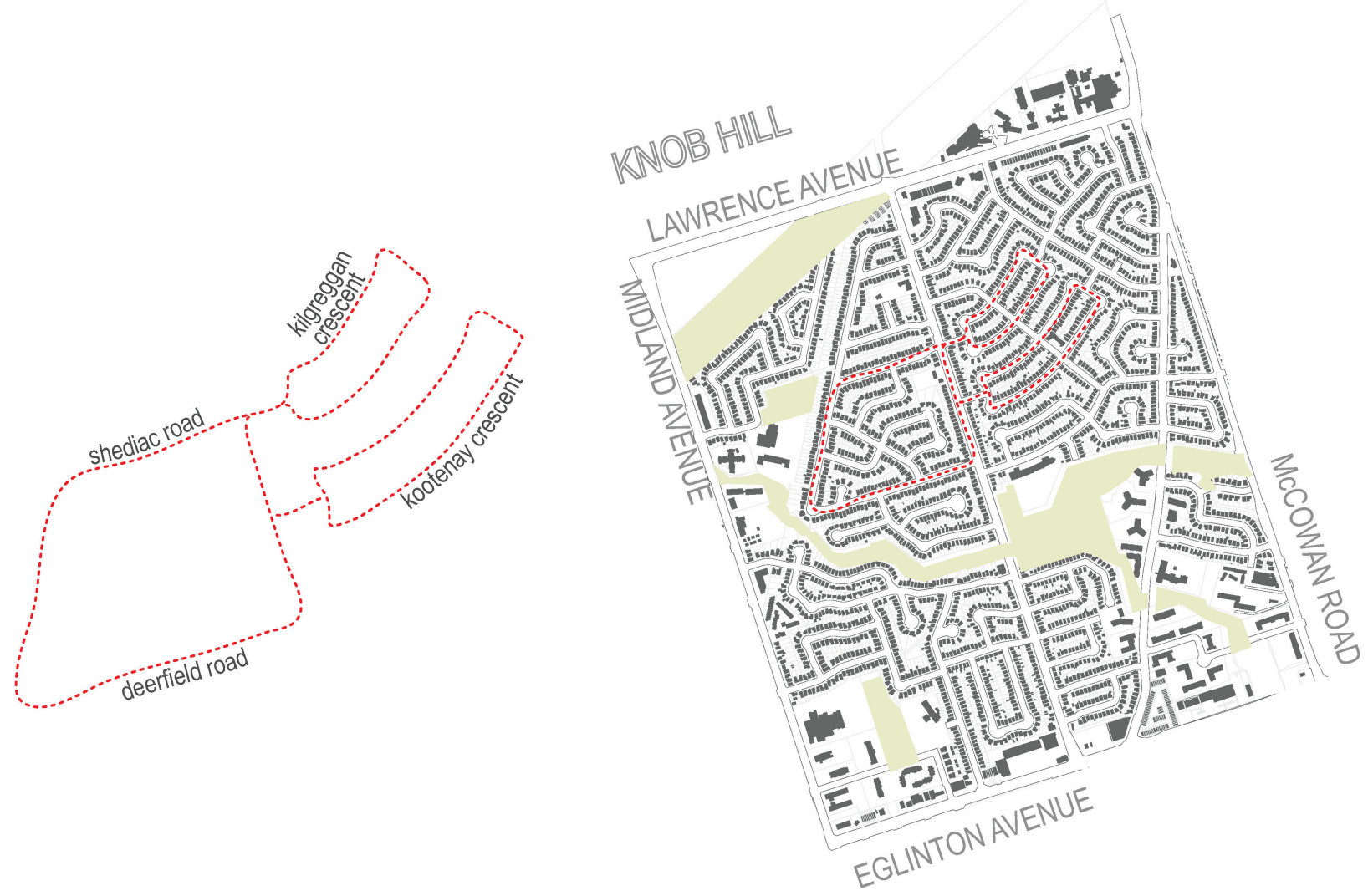

Unproductive - energy, time and resources could be used for more than lawn maintenance

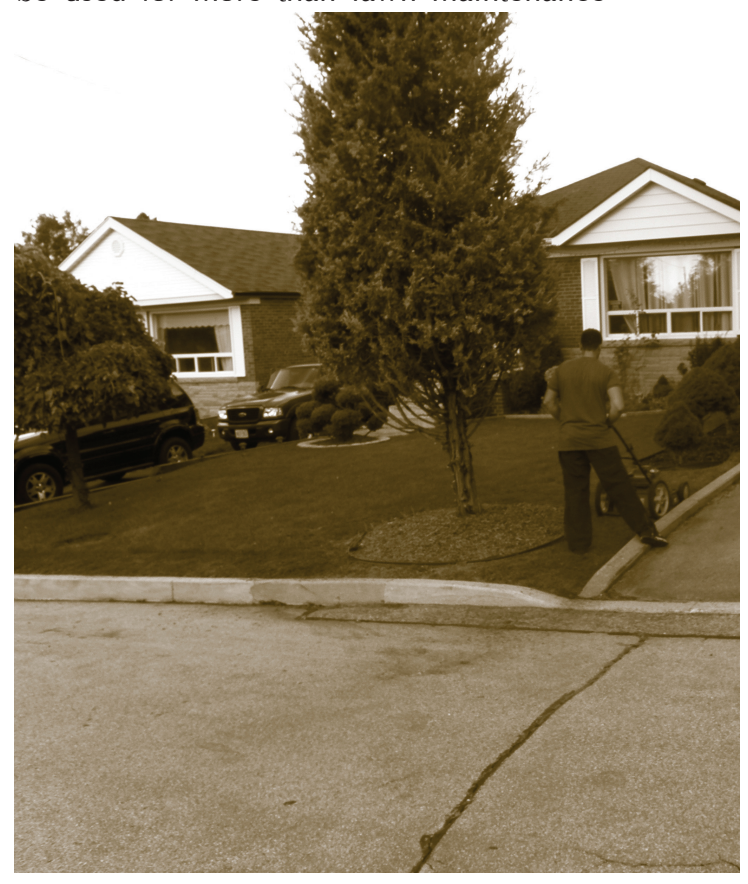

Ad-hoc buildings - evidence of the emergence of outbuildings, including greenhouse structures

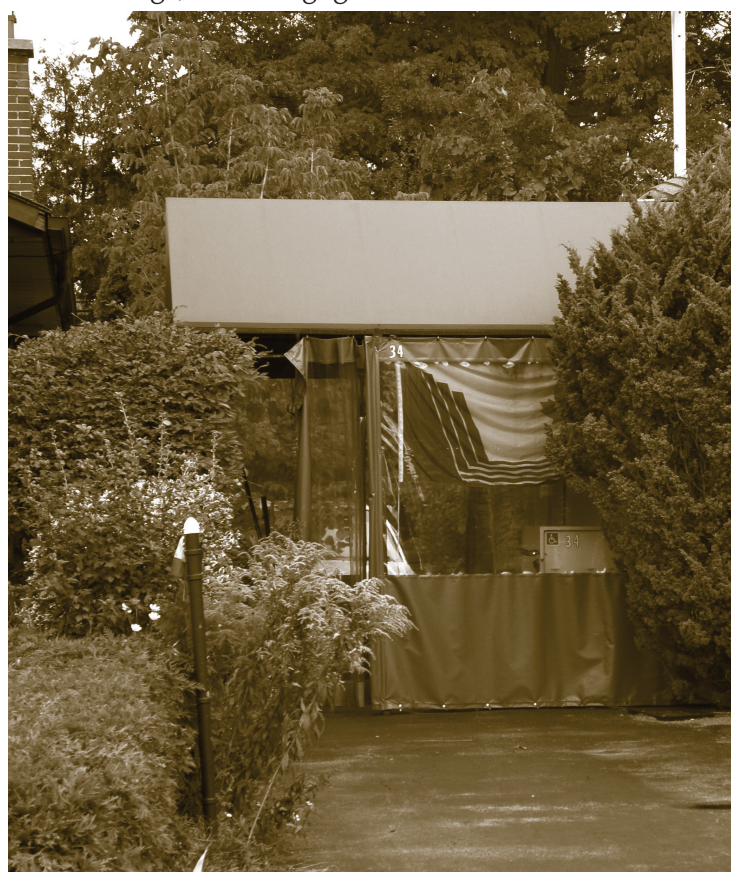


Space - a tremendous amount of space is available in these suburban neighbourhoods

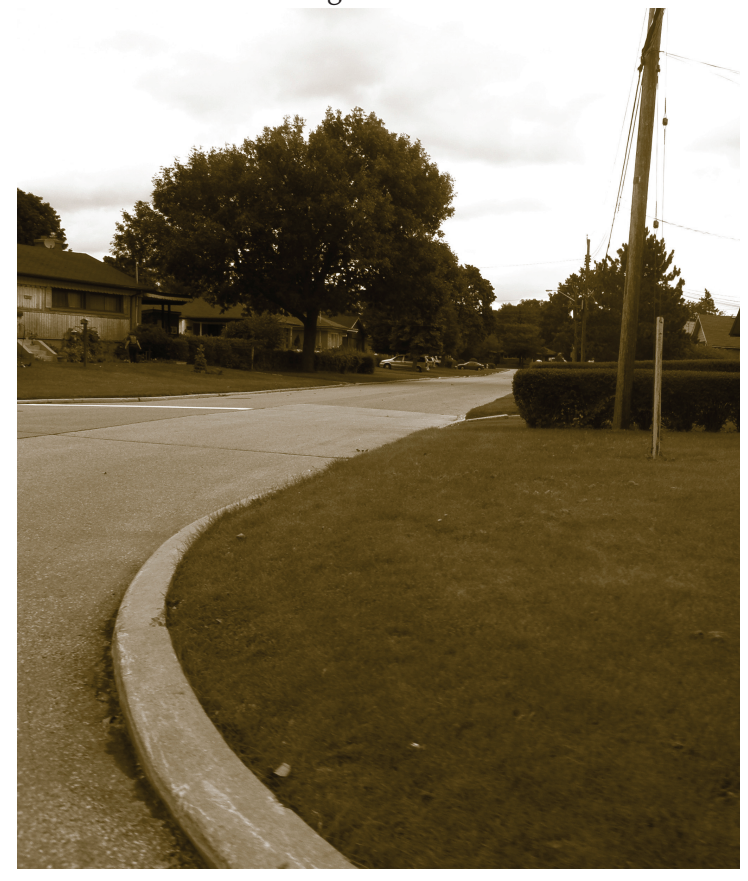

Community - evidence of community activities, and the need to house them

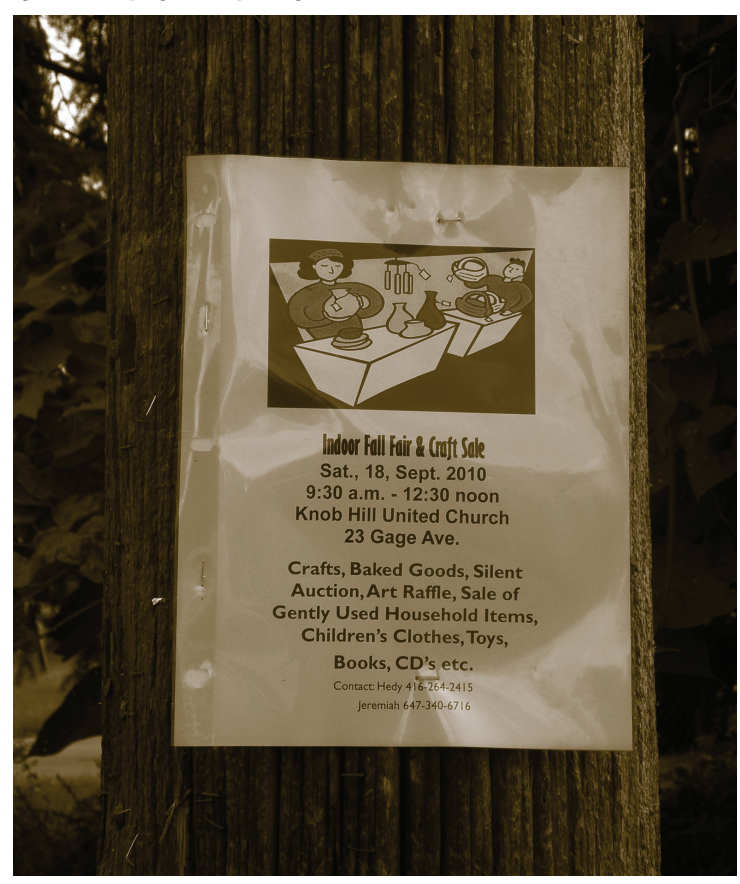

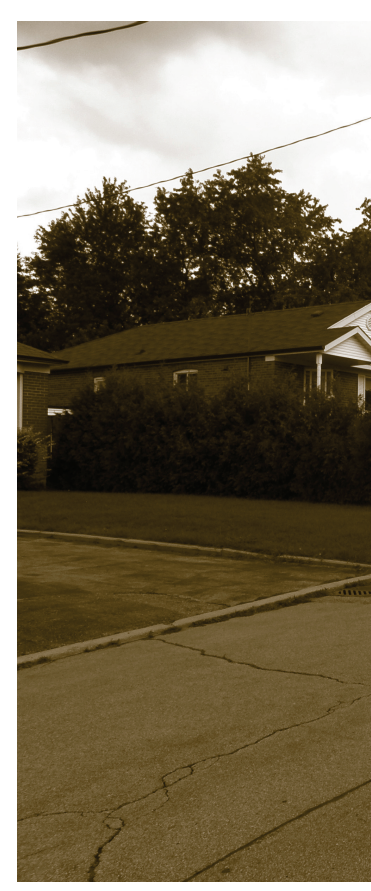


Automobiles - cars are prevalent here, parked on Pavement - the neighbourhood's landscape is the street and in front of homes

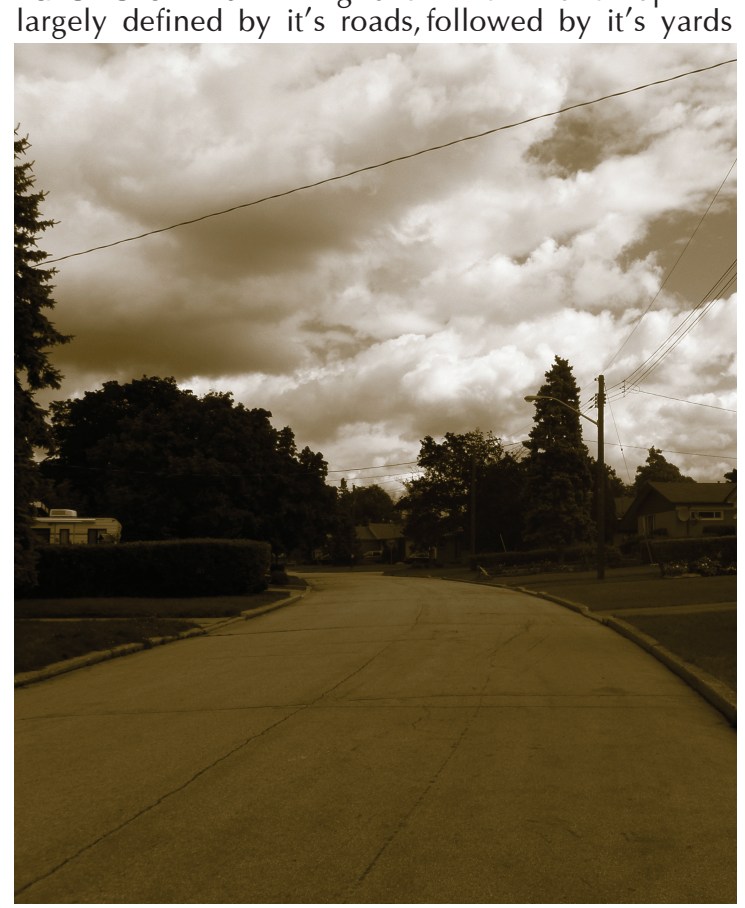




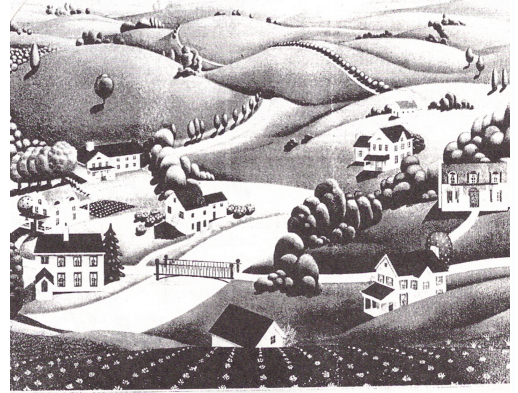

fig. 3.1.3 wellington, the kind of neighbourhood you thought disappeared a hundred years ago the suburbs have a history of being contradictory in nature. Shown here is an advertisement from 1989 selling a Virginia suburban neighbourhood as a picturesque escape from the toils of the city. Rolling hills, lush country side, productive farmland, and natural ecologies are not present in suburban Toronto.

fig. 3.1.4 contradiction of the suburbs Knob Hill is certainly a part of the contradictory nature of the suburbs. The adjacent diagrams begin to dismantle the apparent contradictions between what the suburbs were meant to be and what they are.
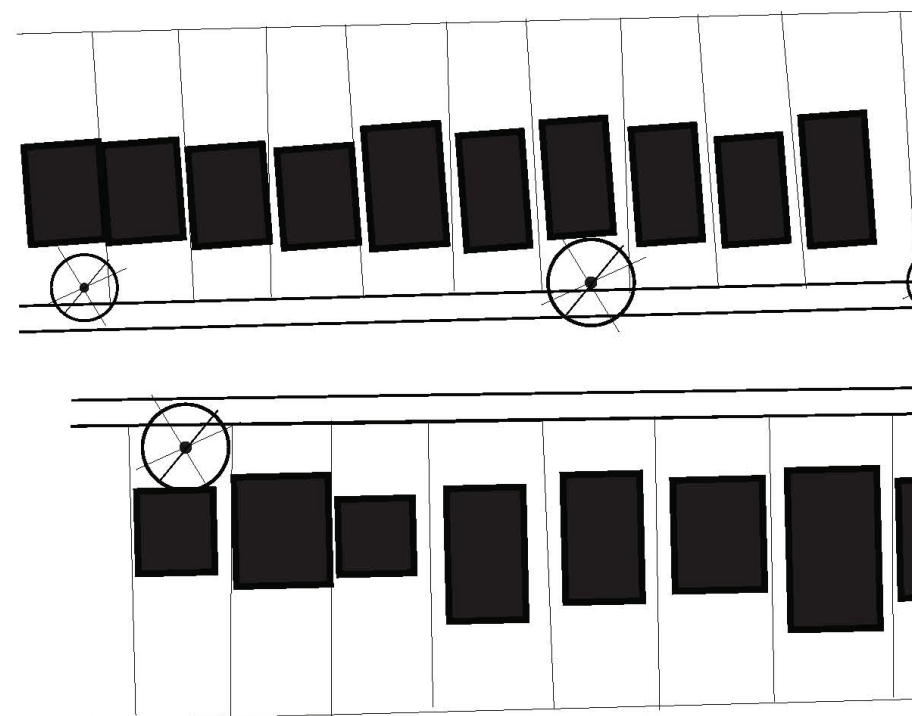

Antithesis to Resilience

Mono-cultural

Dependant

Vulnerable

Planned Reality

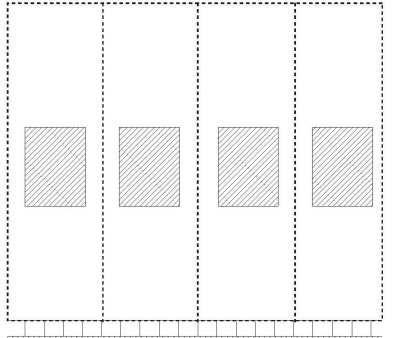

Public

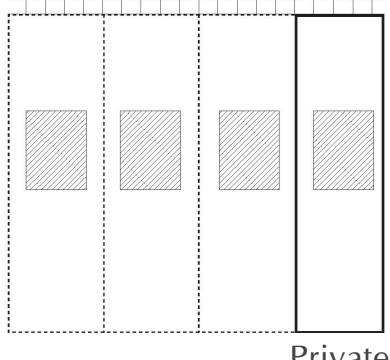

Private

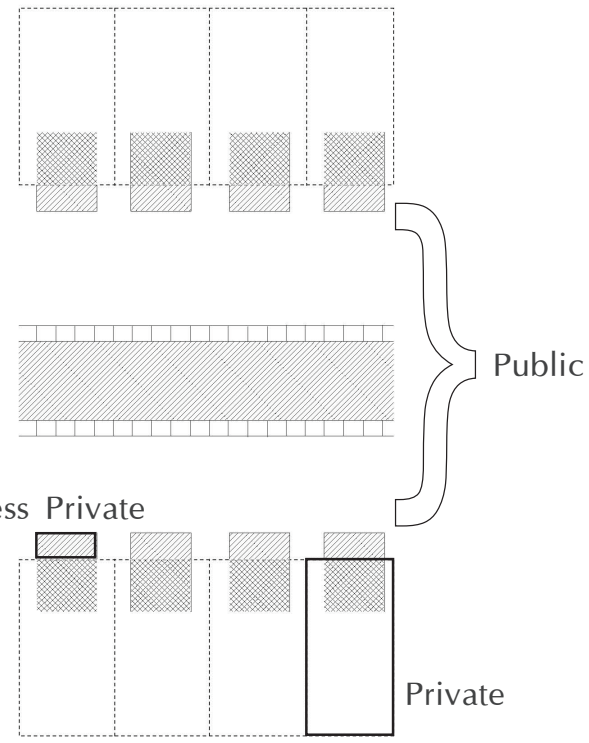



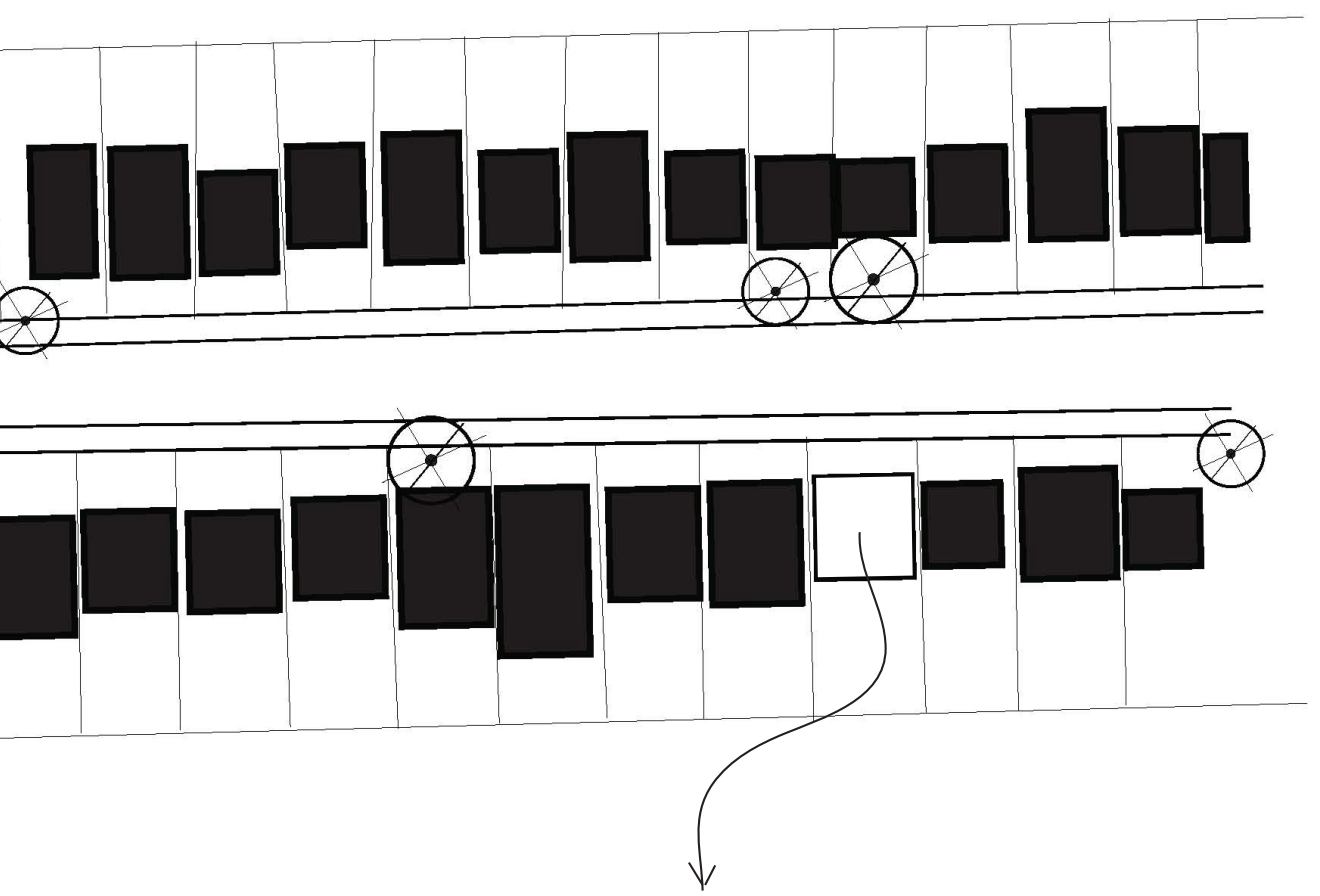

Culture within is not reflected in the Suburban Landscape fig. 3.1.5 the formal failure of the suburbs the inability of suburban developments to reflect the culture of a community is abundantly apparent in a neighbourhood such as Knob Hill. Although on the surface, a neighbourhood like Knob Hill may seem homogenous, it is infact rich in diverse cultural activities. This too demonstrates the contradictory nature of the suburbs. Can the form of these neighbourhoods be re-imagined in such a way to communicate the identity, and character of the cultures they house?

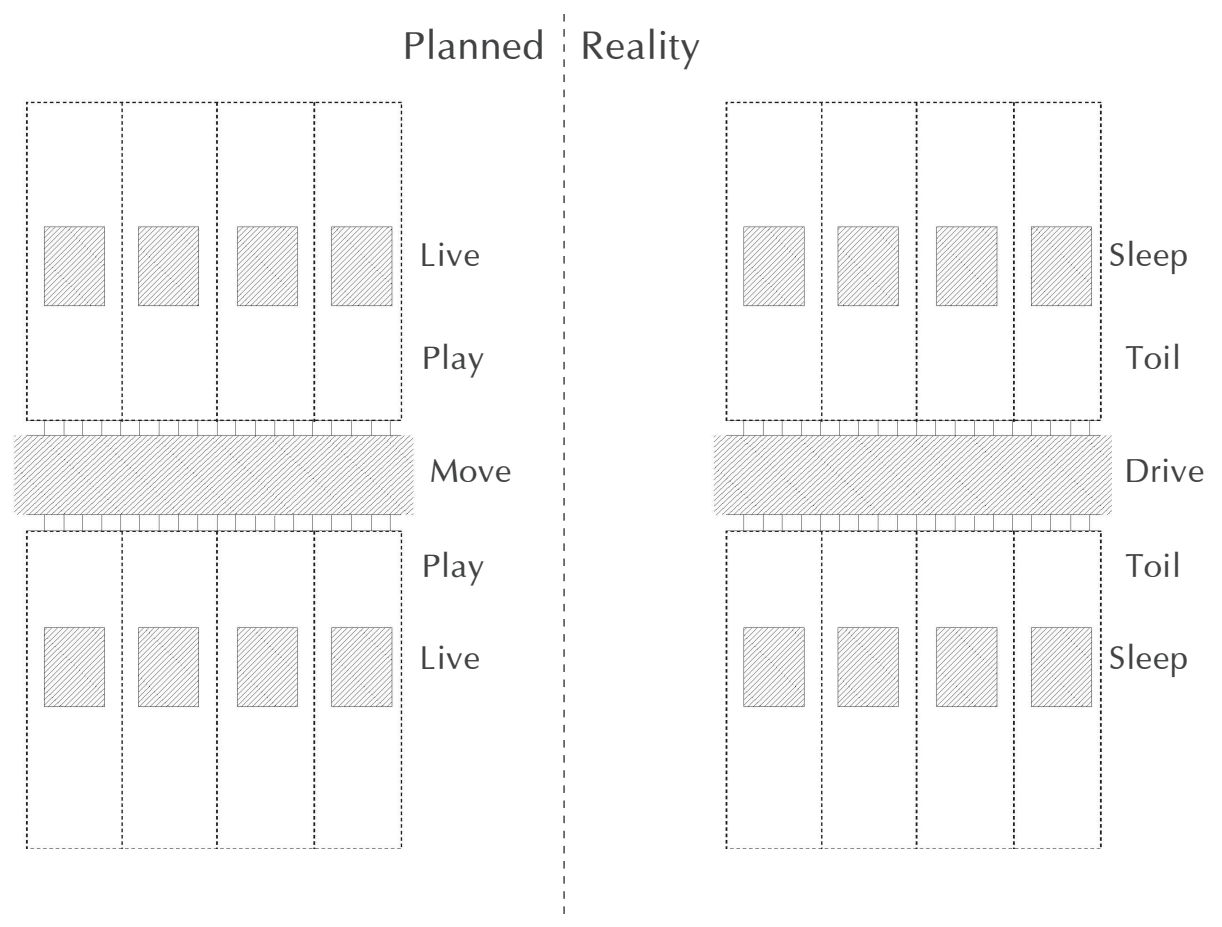



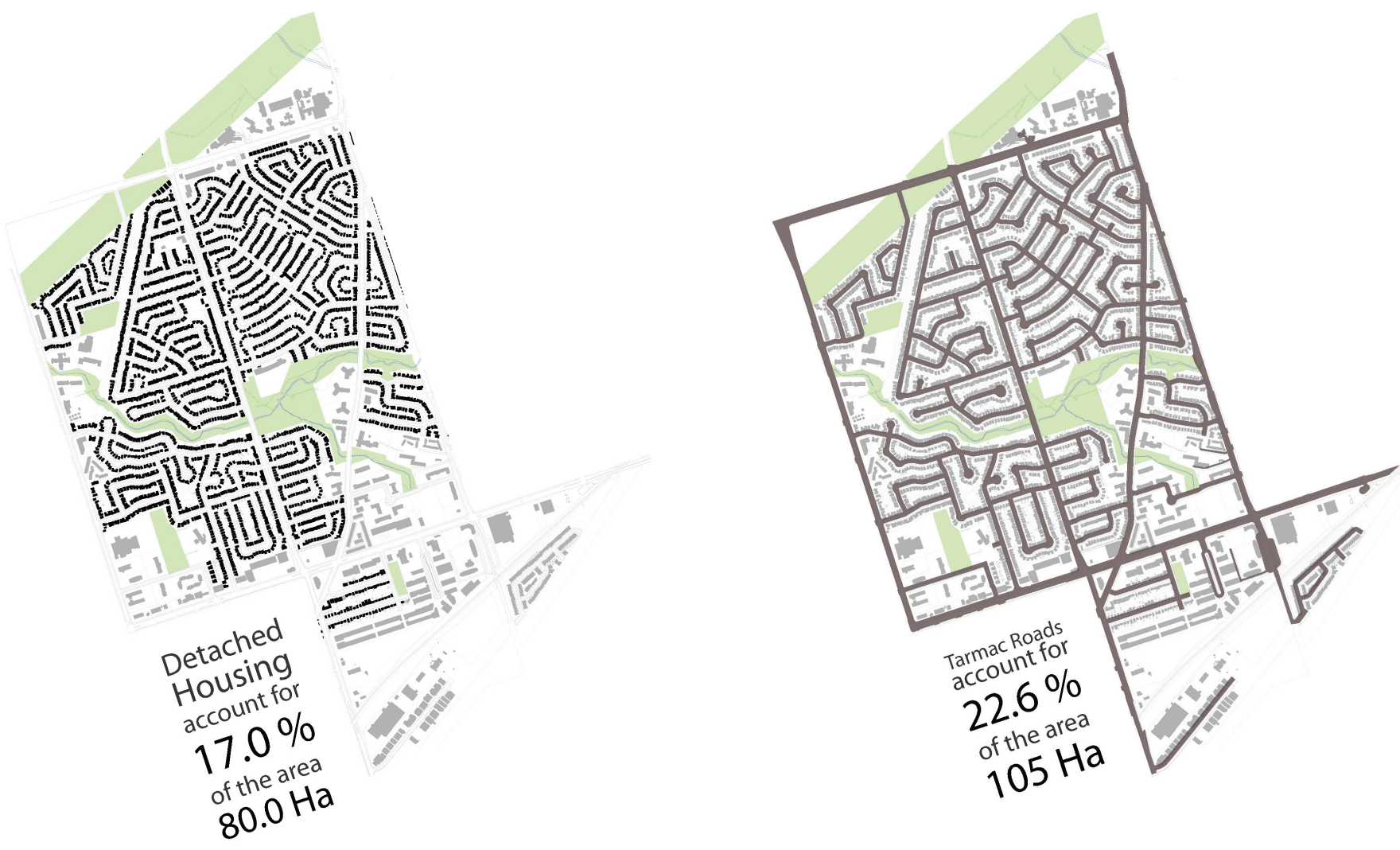

fig. 3.1.6 land availability in Knob Hill most apparent in the exploratory mapping exercise was the sheer amount of available land. If this land could be repurposed, the suburbs of Toronto could begin to play an important role in both housing increasing populations and contributing to the resilience of the city.

Shown are a series of mapping exercises demonstrating the actual amount of land available in Knob Hill. It is no surprise that the detached housing of this neighbourhood amounts to only 17 percent of the land available. If the streets, lawns, driveways and park land of the neighbourhood were rethought, Knob Hill could reimagine itself entirely. How can this sheer amount of land contribute to the resilience of the city or Toronto?

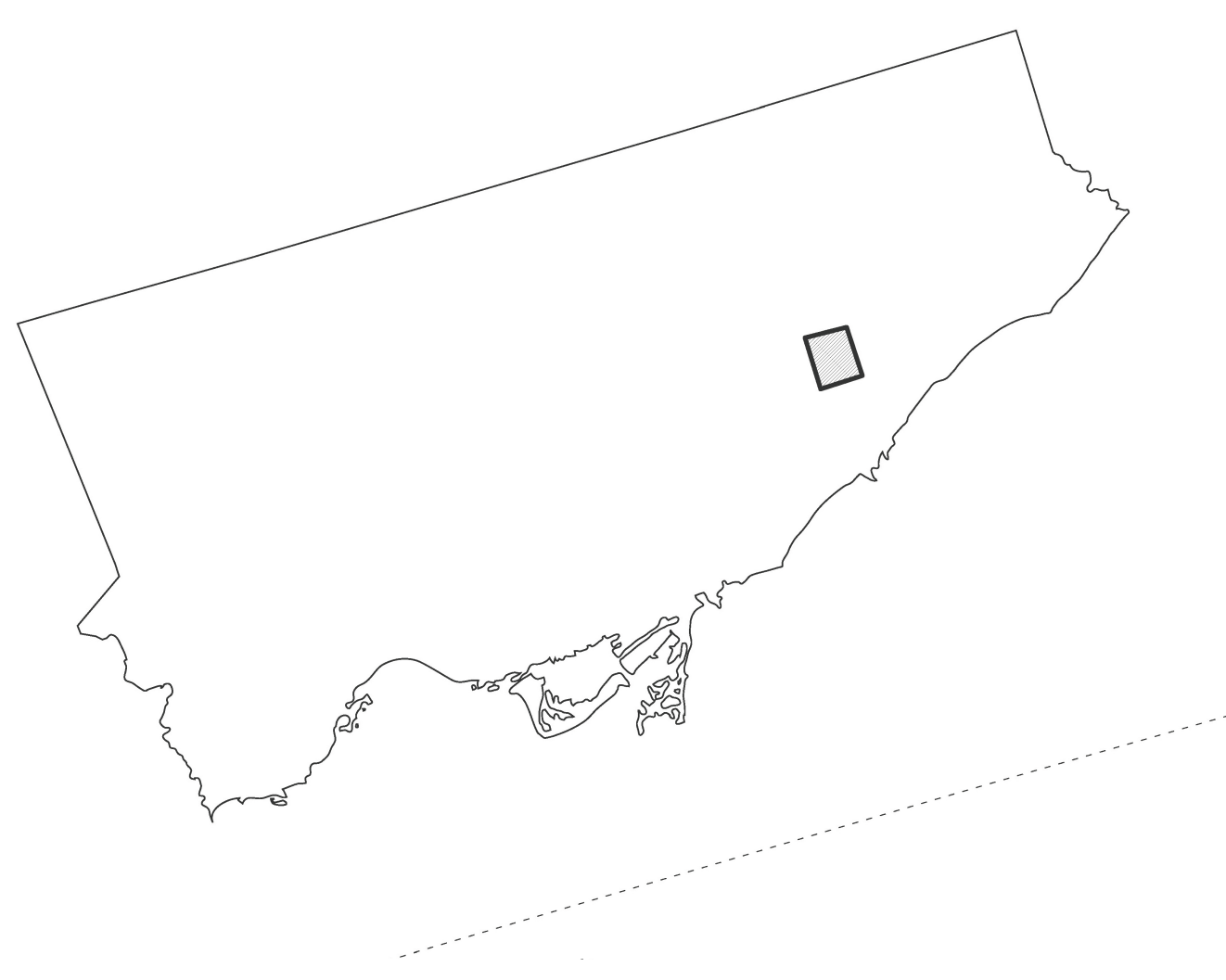



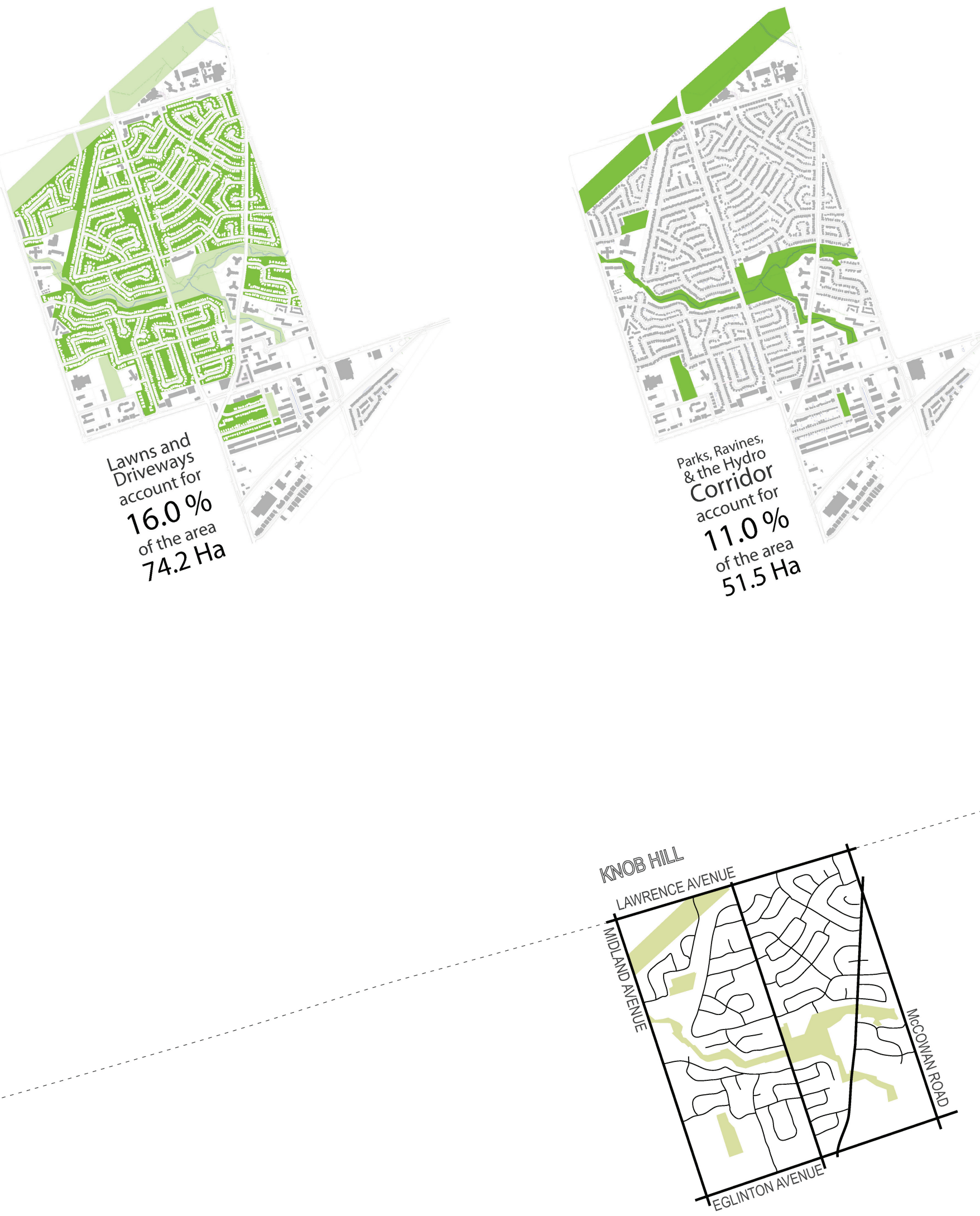

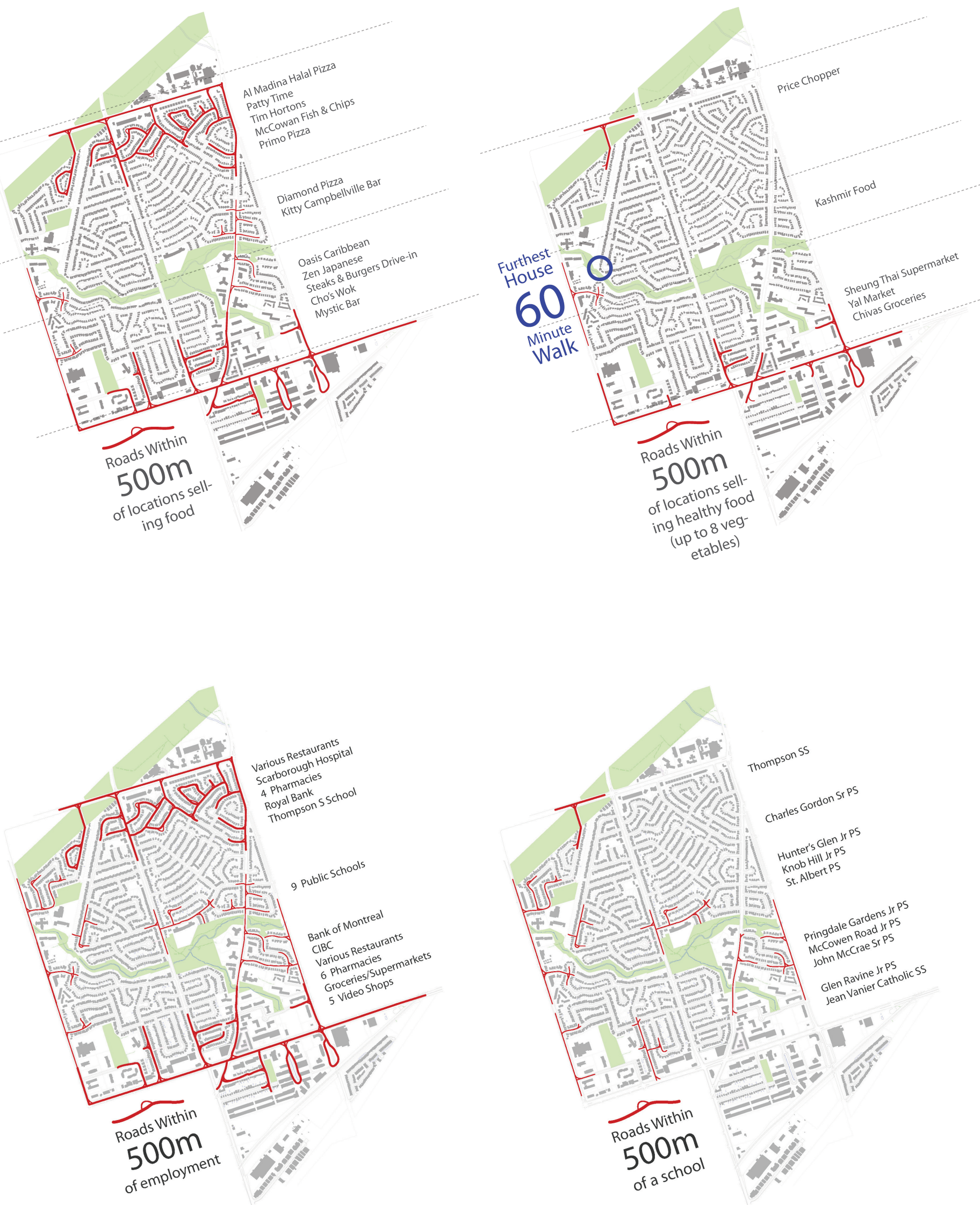


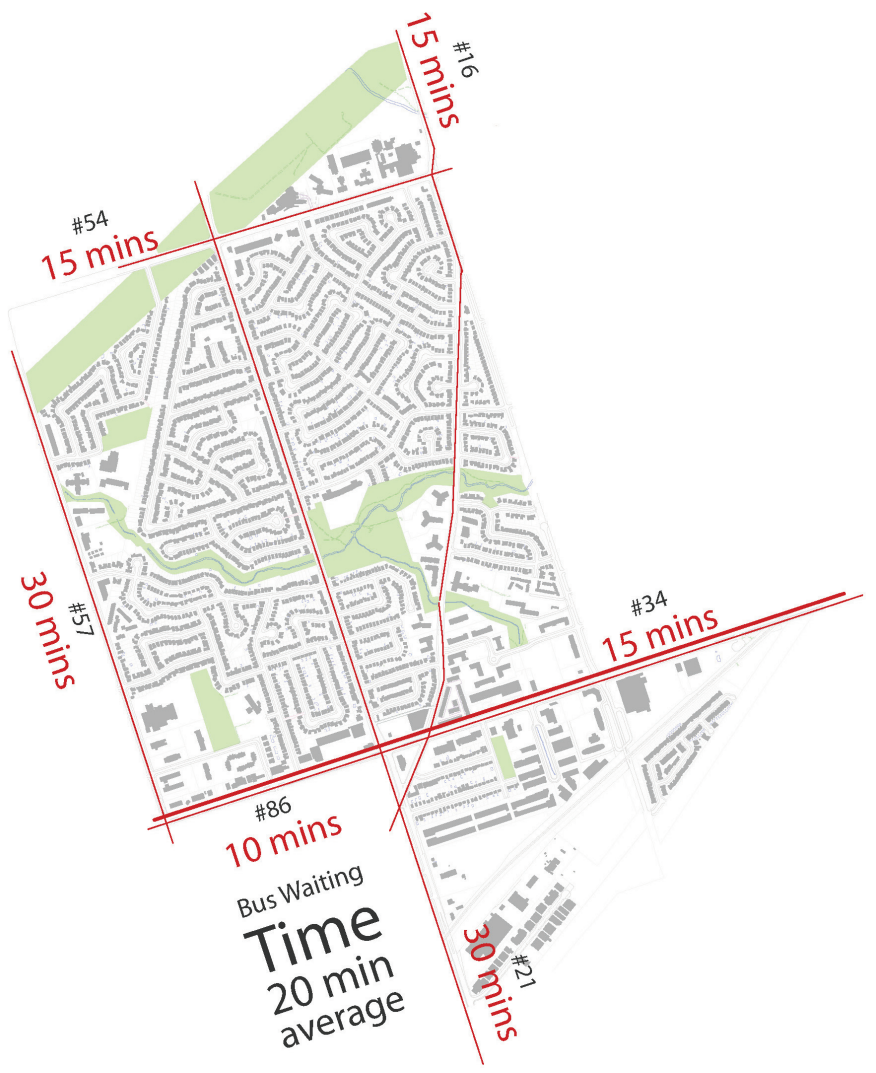

fig. 3.1.7 walking distances of Knob Hill with the sheer amount of space available in Knob Hill comes the increased distances between houses and amenities. Despite the relatively higher overall densities of this suburban neighbourhood (93 people/hectare) Knob Hill is not accessed by rapid transit, nor is it serviced by a range of amenities and employment opportunities. The following mapping exercises demonstrate the impossibility of this neighbourhood in becoming independent of the automobile without substantial redevelopment - noted most strongly in the food-shed diagram indicating the farthest house from a source of healthy food (60minute walk).

Even considering the current and up-coming proposals for the city of Toronto (densifying the arterials and the Mayor's tower renewal) Knob Hill remains inaccessible to anything other than the automobile. As indicated in the final diagram of the series, nodes will need to be developed from within the neighbourhood; nodes that would begin to provide some essential amenities and employment opportunities within walking distances.
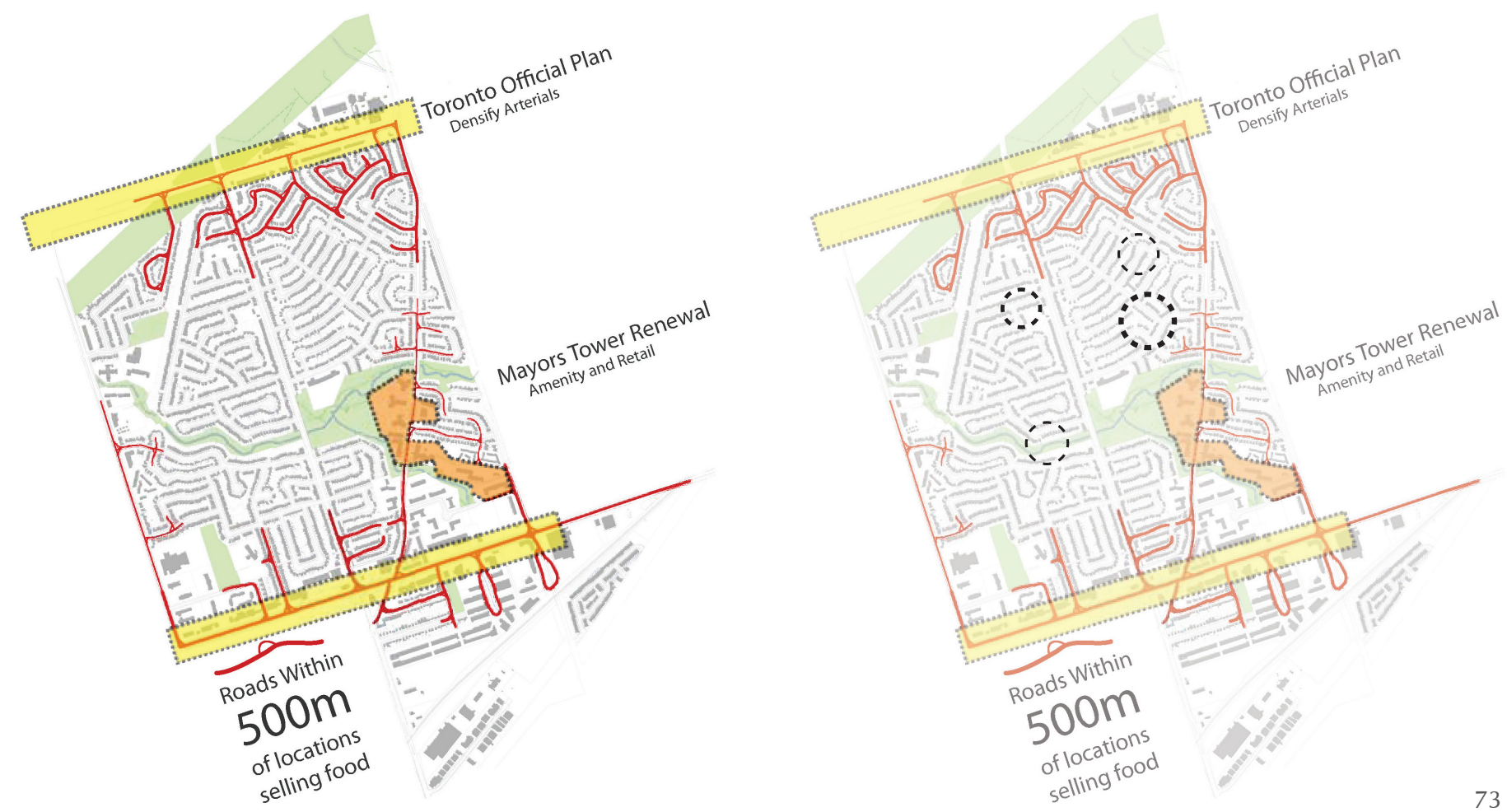
fig. 3.1.8 urban harvest mapping for Knob Hill - current condition In order to investigate the needs of Toronto in a resilient future, and the role that the suburbs would play in such a future, a series of urban harvest mapping exercises were undertaken. The mapping exercises begin to show graphically the distinct role that lower density suburbs have to play in balancing the density of the city, and providing a means for the city to meet most of it's own needs. As noted earlier in the report, some argue that the suburbs need to be replaced with high density developments. As this series of mapping exercises begin to suggest, while added density is neccessary, lower densities and landscape-dominated neighbourhoods such as Knob Hill have a distinct role to play in balancing the needs of the city by becoming productive grounds upon which to provide Toronto with clean air, water, energy, and food.

Currently, Knob Hill has two distinct housing typologies defined by two distinct densities - the suburban, single family, detached house and the corbusian tower apartment block. As is demonstrated, the needs of the tower block, due to its higher density, is much greater than the needs of it's suburban neighbouring blocks. Although tower apartments free up the ground-plane, tower block densities ultimately push the productivity of a city ever outwards towards the hinterlands of the city. Whereas, suburban blocks are in fact able to meet most of their needs from within the land they inhabit.
Hot water. (solar collectors)
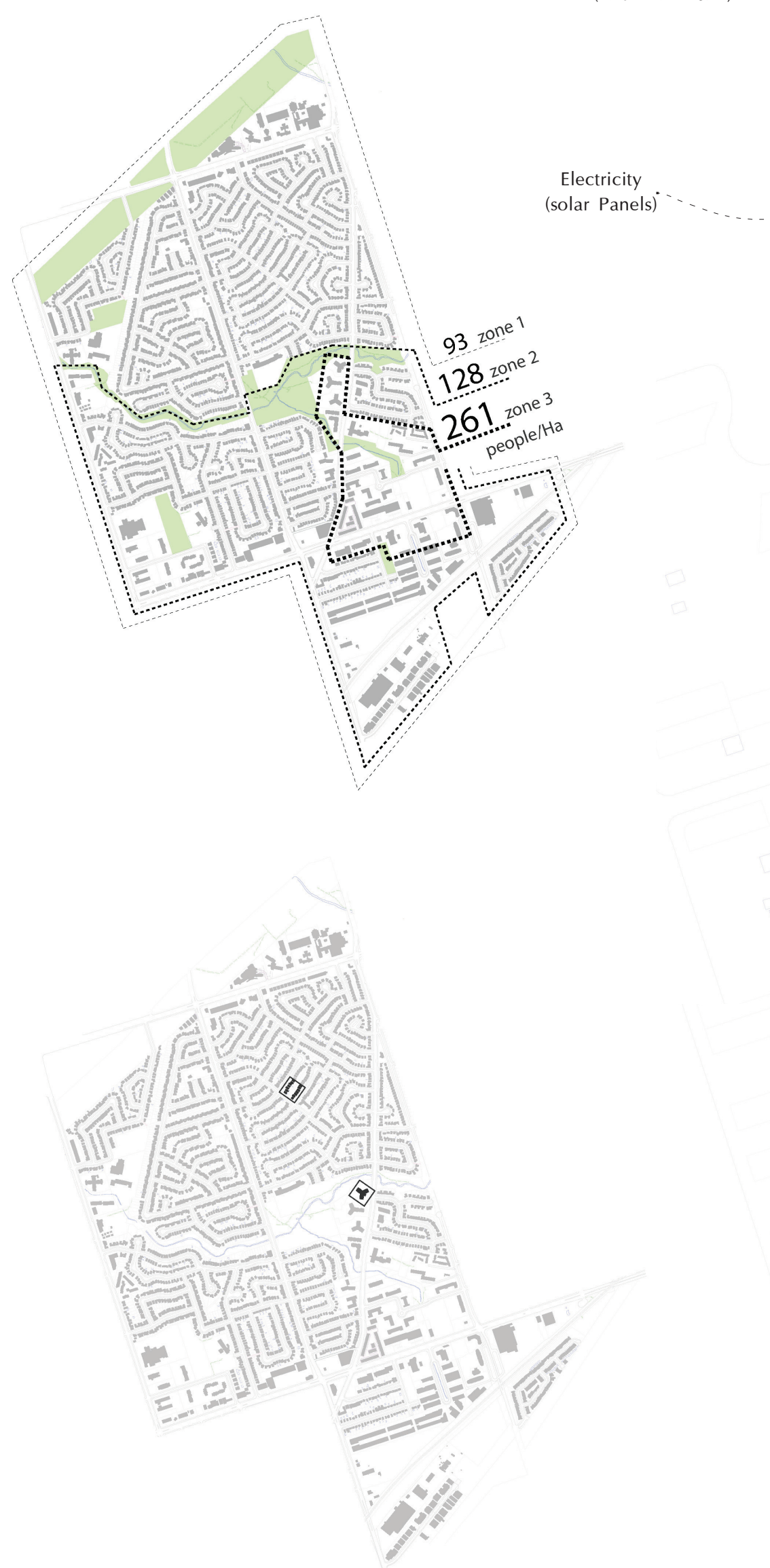

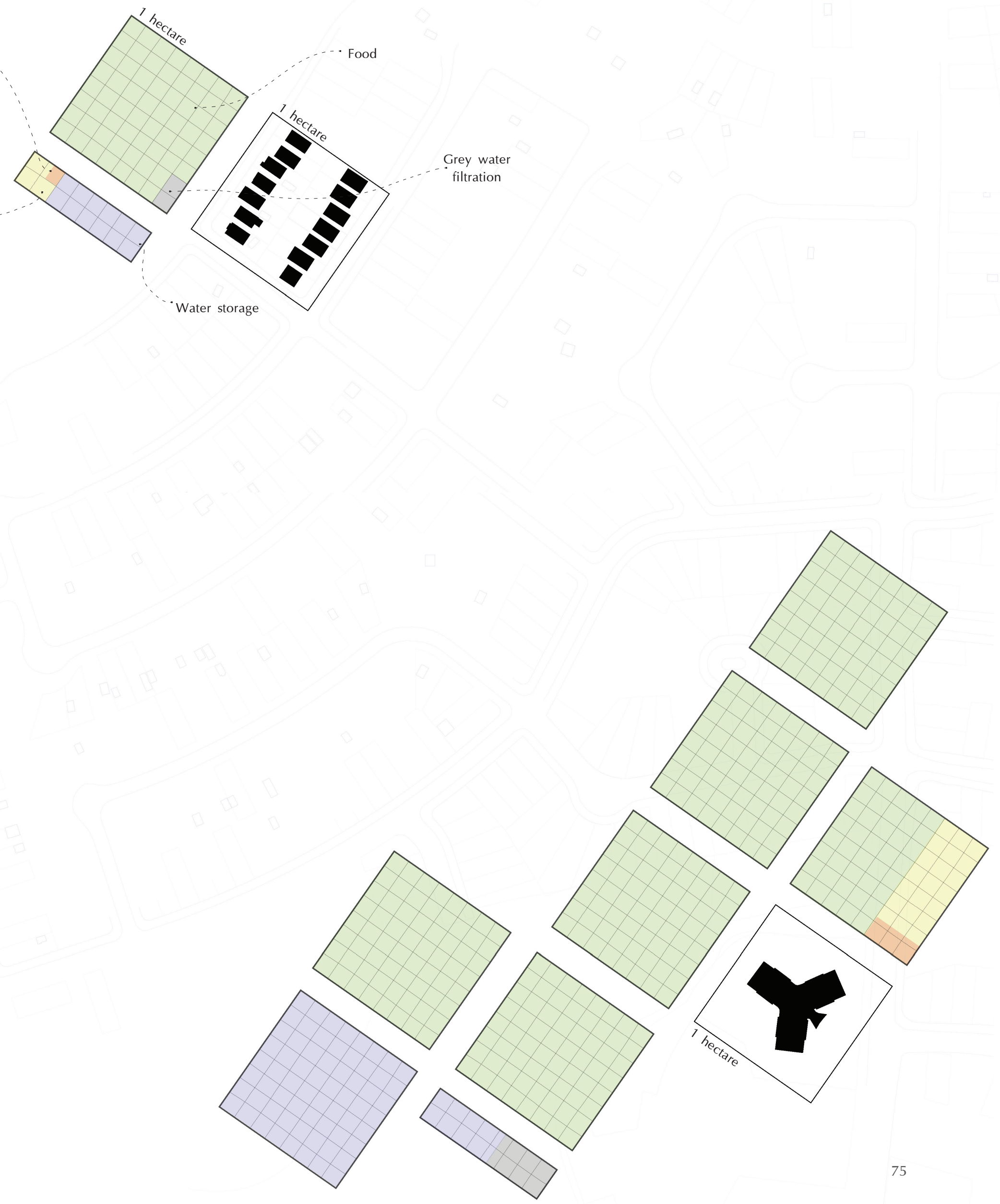
fig. 3.1.9 urban harvest mapping for Knob Hill - a marriage between lower and higher densities when the neighbourhood is considered as a whole, with both the lower densities of the suburban housing blocks and the higher densities of the tower block, a substantial reduction in the needed productive ground can be seen. Instead of the tower block requirements of 7.2 hectares of land, the combined effect of suburban neighbourhoods with high density blocks equates to a much lower required 2.6 hectares of land. This is infact a typical condition in all of surburban Toronto as such tower blocks are distributed evenly throughout the city (as demonstrated in the Mayor's Tower Renewal). A marriage between the high density arterials and tower blocks and lower density suburban neigbourhoods must be acknowledged and stressed in any discussion regarding suburban renewal. Adding density to these neighbourhoods will help in the renewal of Toronto's suburbs, but these neighbourhoods do have a vital role to play in balancing the needs of the city and providing productive landscapes.

fig. 3.1.10 urban harvest mapping for Knob Hill - a layering of productivity when considering innovative measures for incorporating productive activities into urban centers (greenroofs, greenwalls, underground water cisterns, integrated solar panels, etc.) it is clear that a layering of productivity is possible. With such a layering of productivity, it is conceivable that Toronto could meet over $50 \%$ of its needs from within the city itself, with the remainder coming from outside the city. Toronto's suburbs must be re-invisioned as productive grounds, areas where the dominating landscapes are re-used to clean the air and water, and to produce food and energy. Such lower density neighbourhoods of the city have a vital role to play in it's future durability.
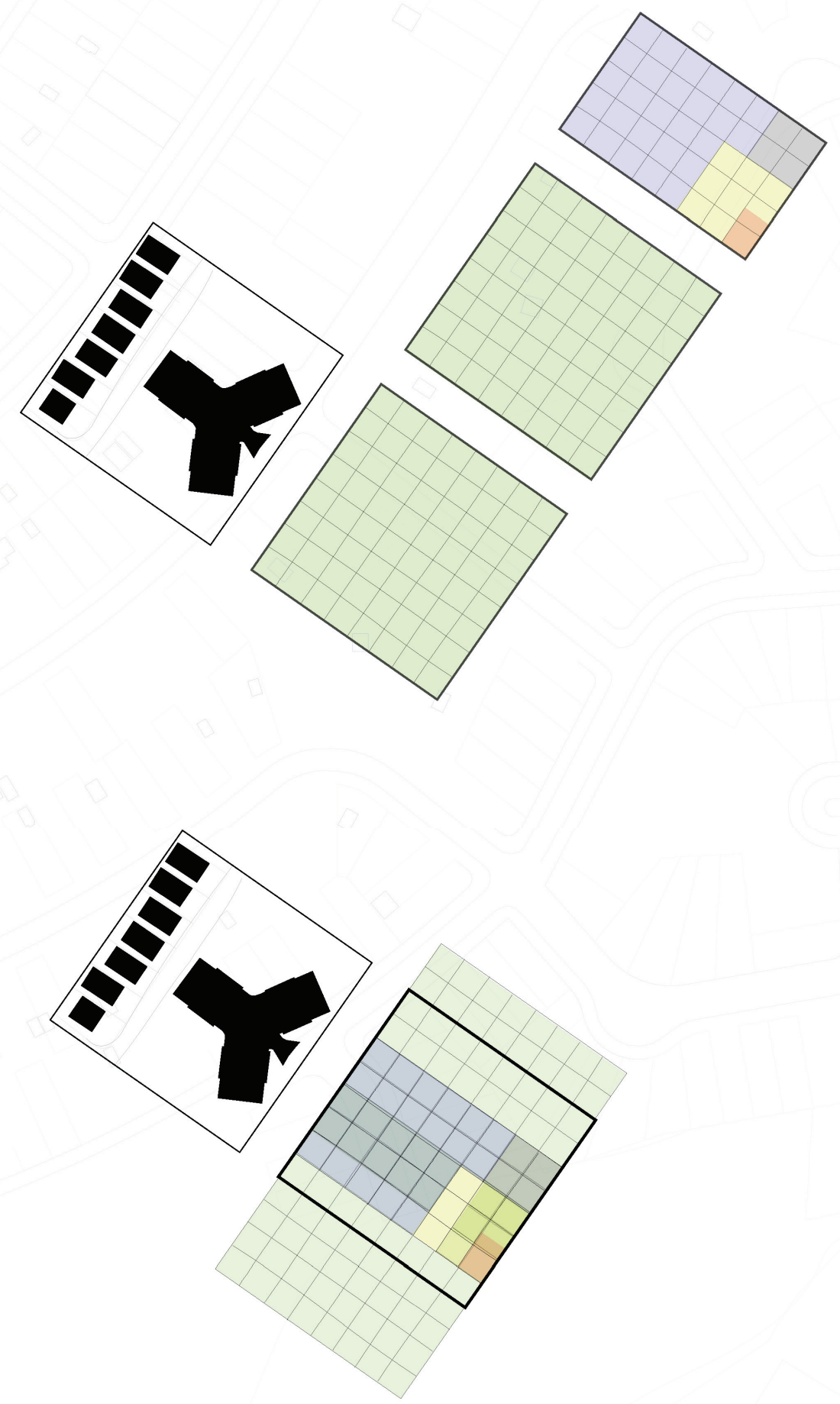
3.2 productivity matrix To better understand the range of potential in suburban Toronto, the following section documents a matrix of potential strategies that was created based on the Knob Hill mapping exercises. Such explorations were performed at the scale of the house, yard, street and lane, and examined ways to make these specific suburban spaces productive. The location of the house and yard fall under the scale of property ownership and private execution, while the location of the street and lane occur at the scale of the neighbourhood and community collaboration. The themes that were focused on were water, ecology, food, energy, and material.

The matrix is a direct result of the urban harvest mapping exercises undertaken earlier and aims to specifically examine what productive measures can be implemented into suburban Toronto, and where such productive measures could be located. Five elements of the matrix are detailed, indicating the focus and intent of the five productive categories. This section concludes by looking at the interrelationship of the five productive categories,linking them in a correlation diagram, and suggesting mutually beneficial, synergistic relationships amongst the varying strategies.

The production of the productivity matrix was instrumental in understanding the range of possibilities available in suburban Toronto, and also locating where such strategies could be implemented. As will be demonstrated, it led to the formation of a framework for redevelopment, and the creation of 5 typologies for suburban Toronto based on the themes of water, ecology, food, energy, and materials. 
Water

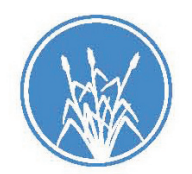

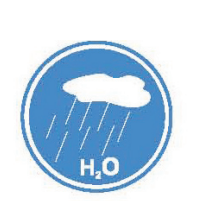
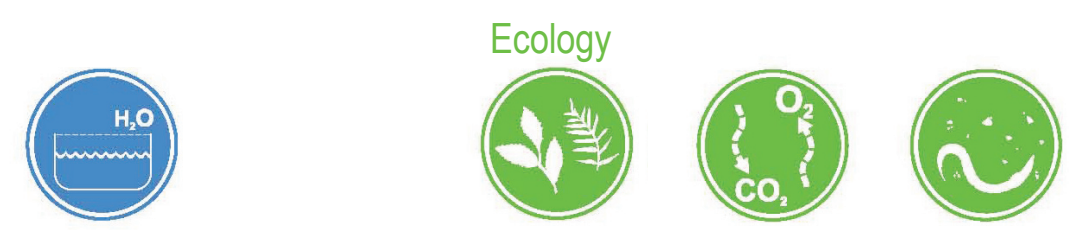

Food
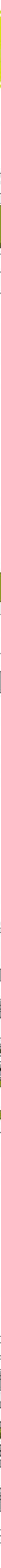


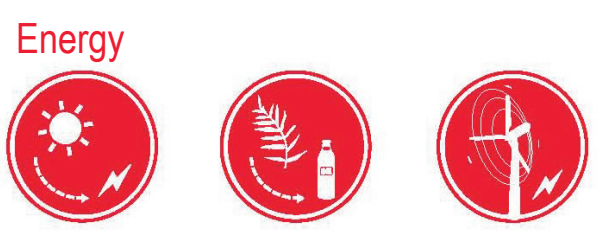

Material

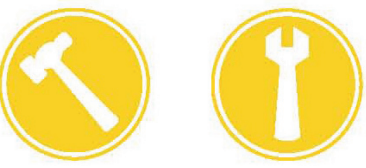

(2)
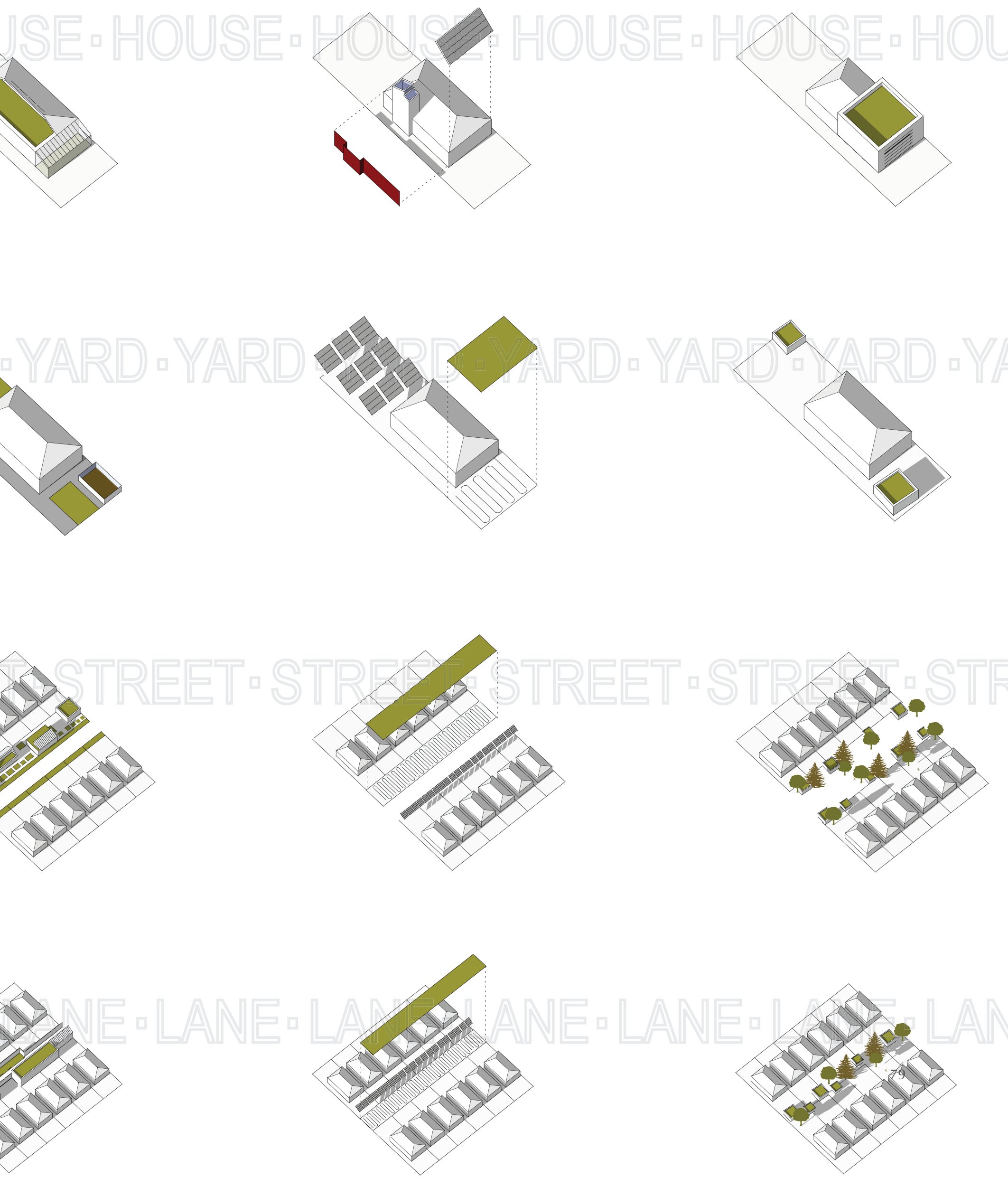
previous
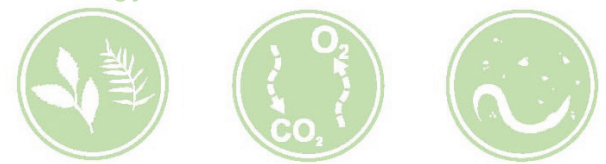

fig. 3.2.1 matrix of potential strategies showing the range of possible strategies, - water, ecology, food, energy, material - organized into four locations: house, yard, street, and lane
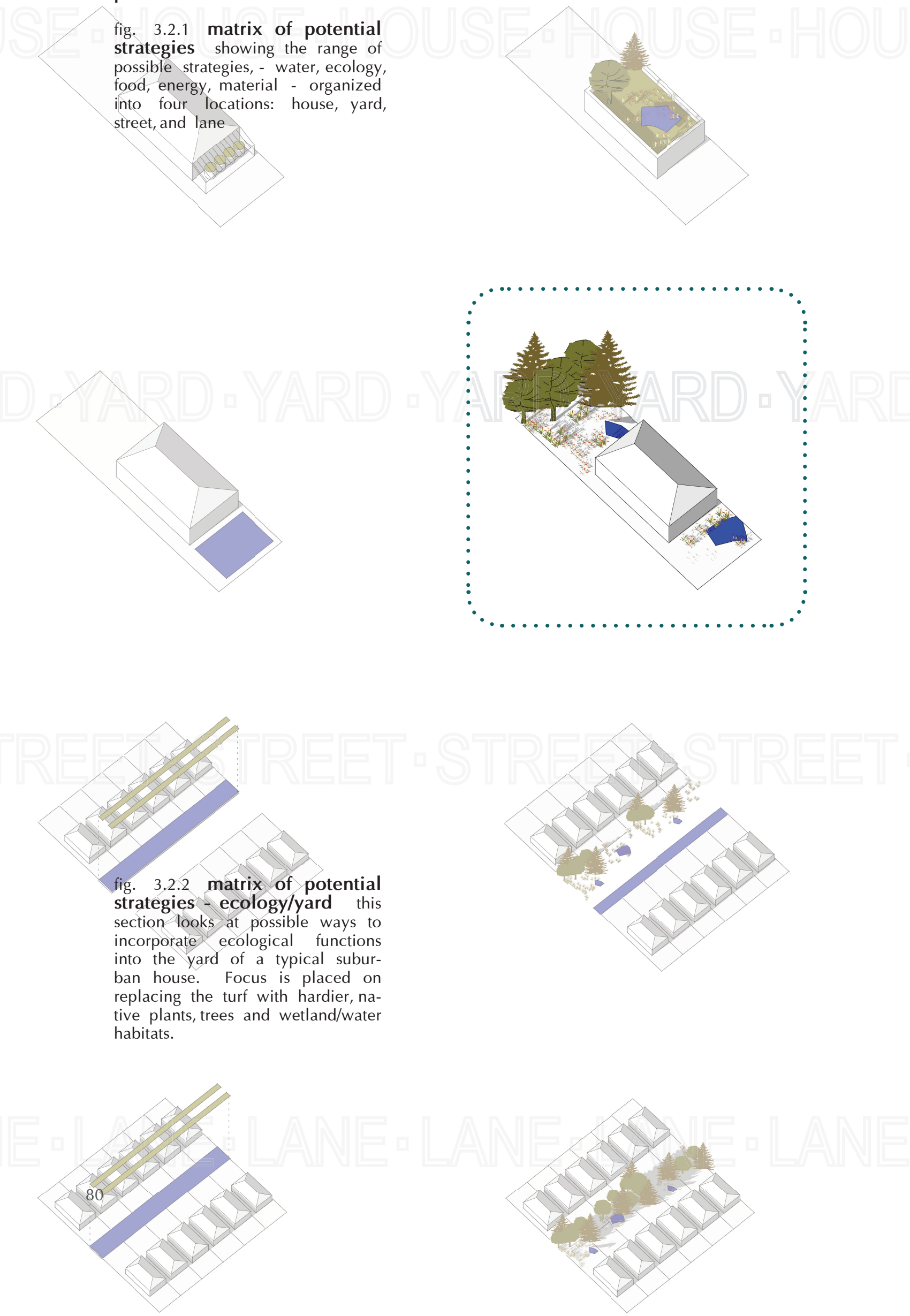

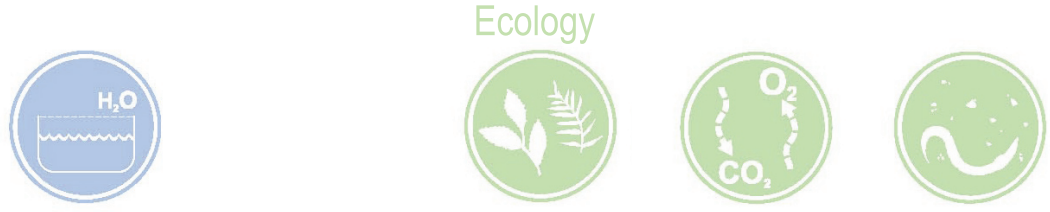

(81)
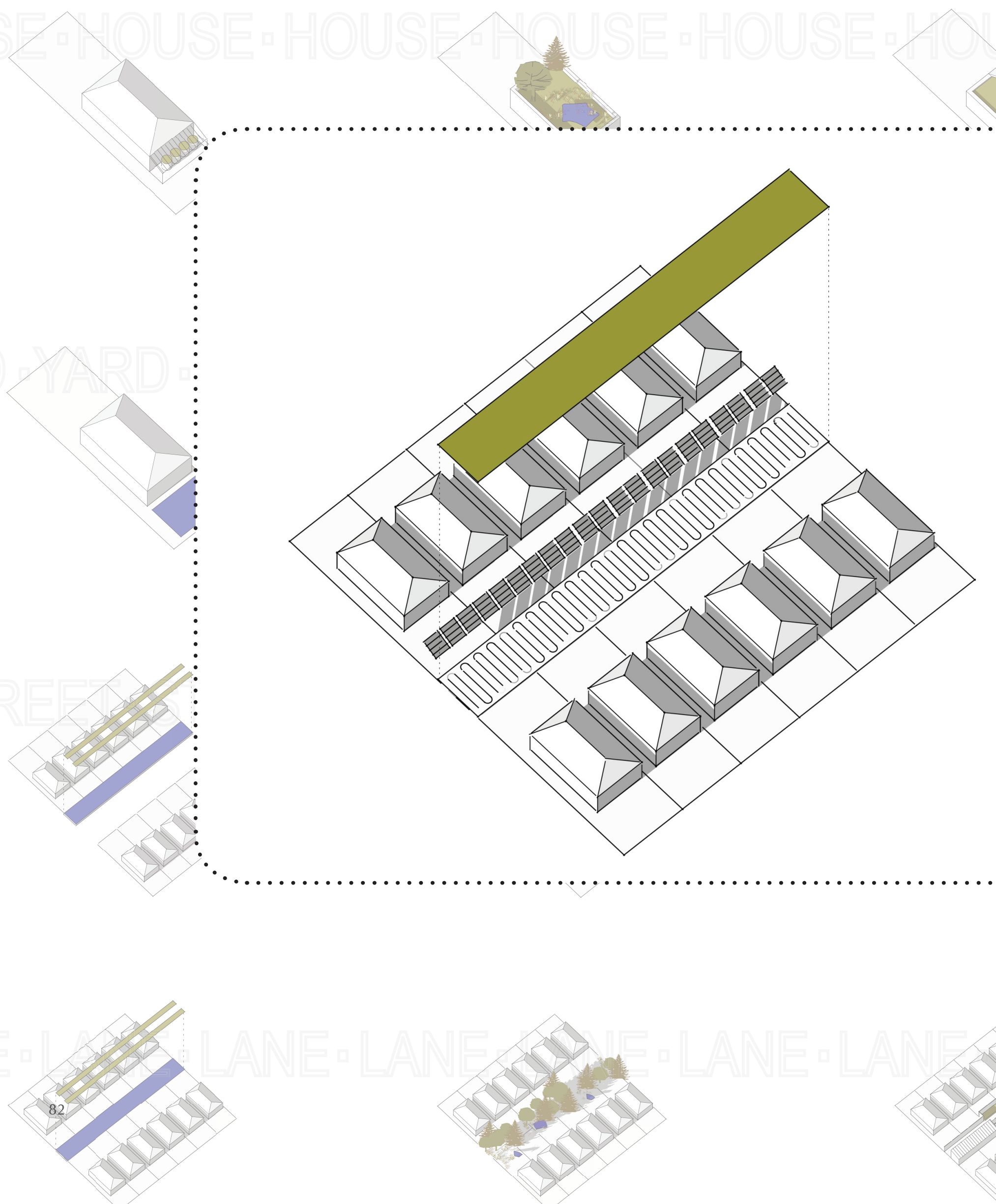

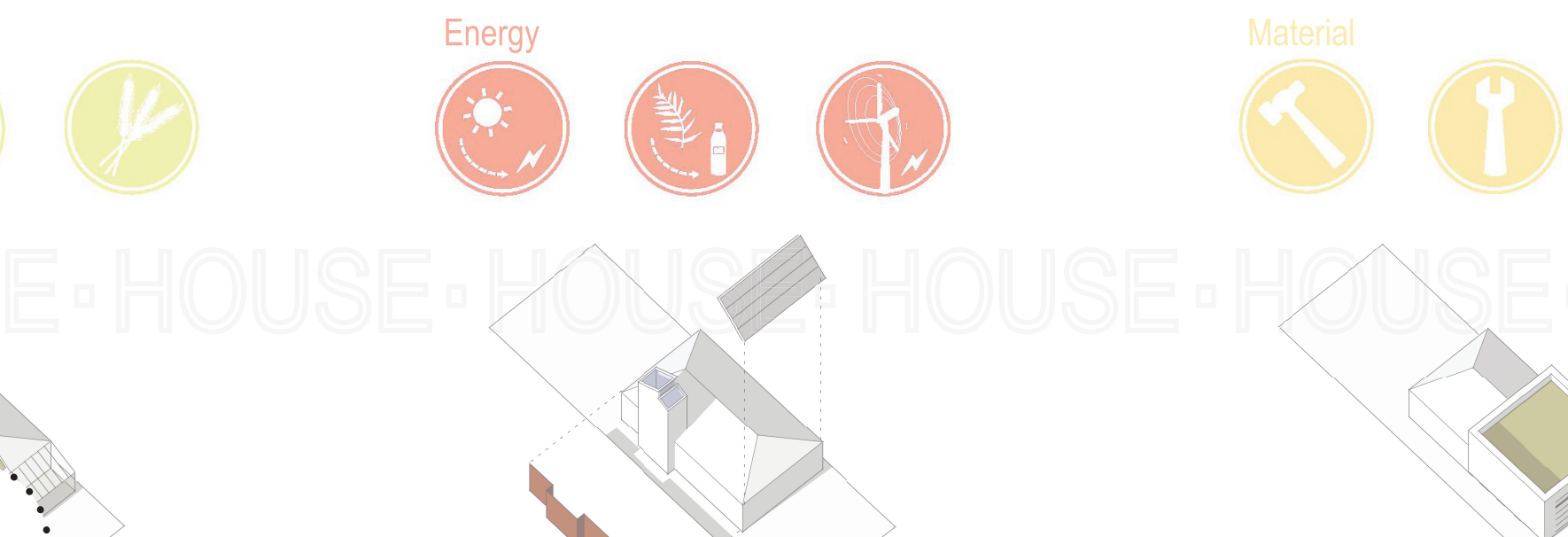

\section{ENERGY - LANE}
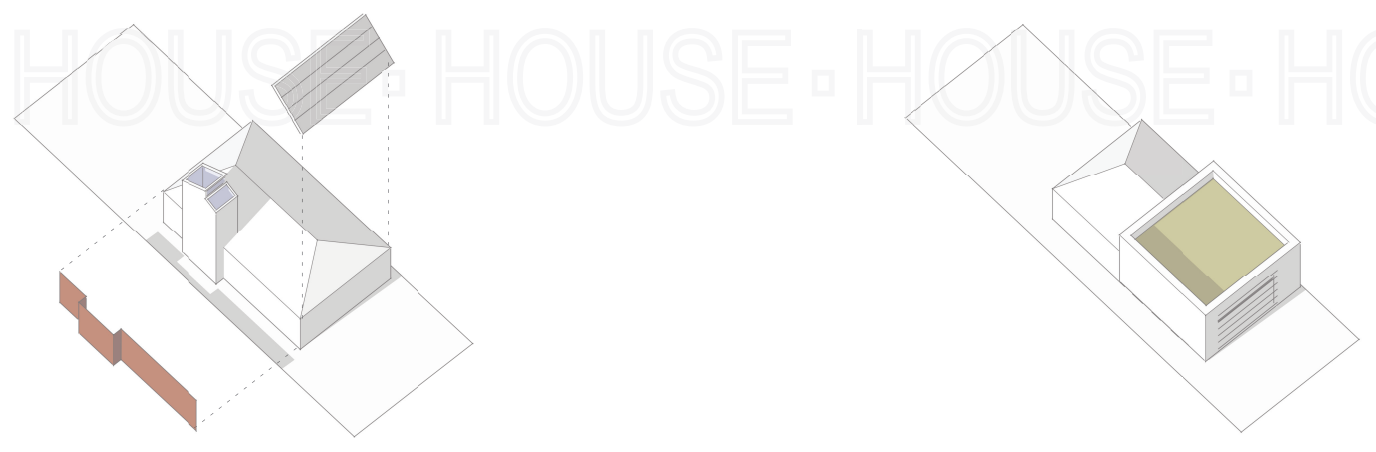

Photovoltaic Panels

Solar Hot Water Panels

Geothermal Heating

Geothermal Cooling

Bio Fuel Cultivation

Wind Turbines

Heat Recovery

Vegetable Waste Fuel

Urban Tree Waste Fuel

Combined Heat and Power

Passive Solar Heating

Passive Cooling Ventilation

Heat Storage/Sinks

Solar Envelope
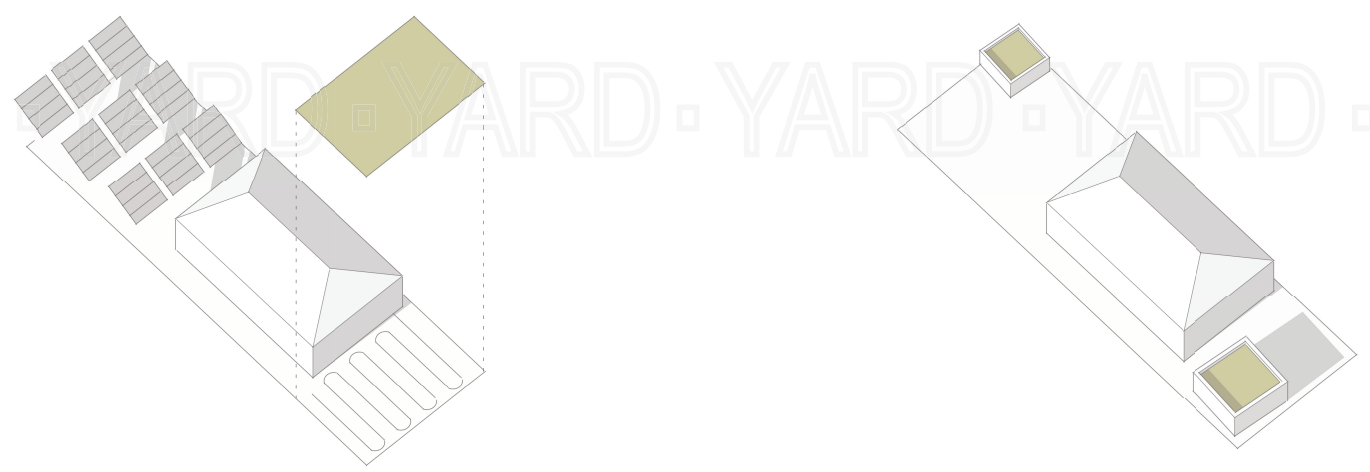

Smart Technologies 

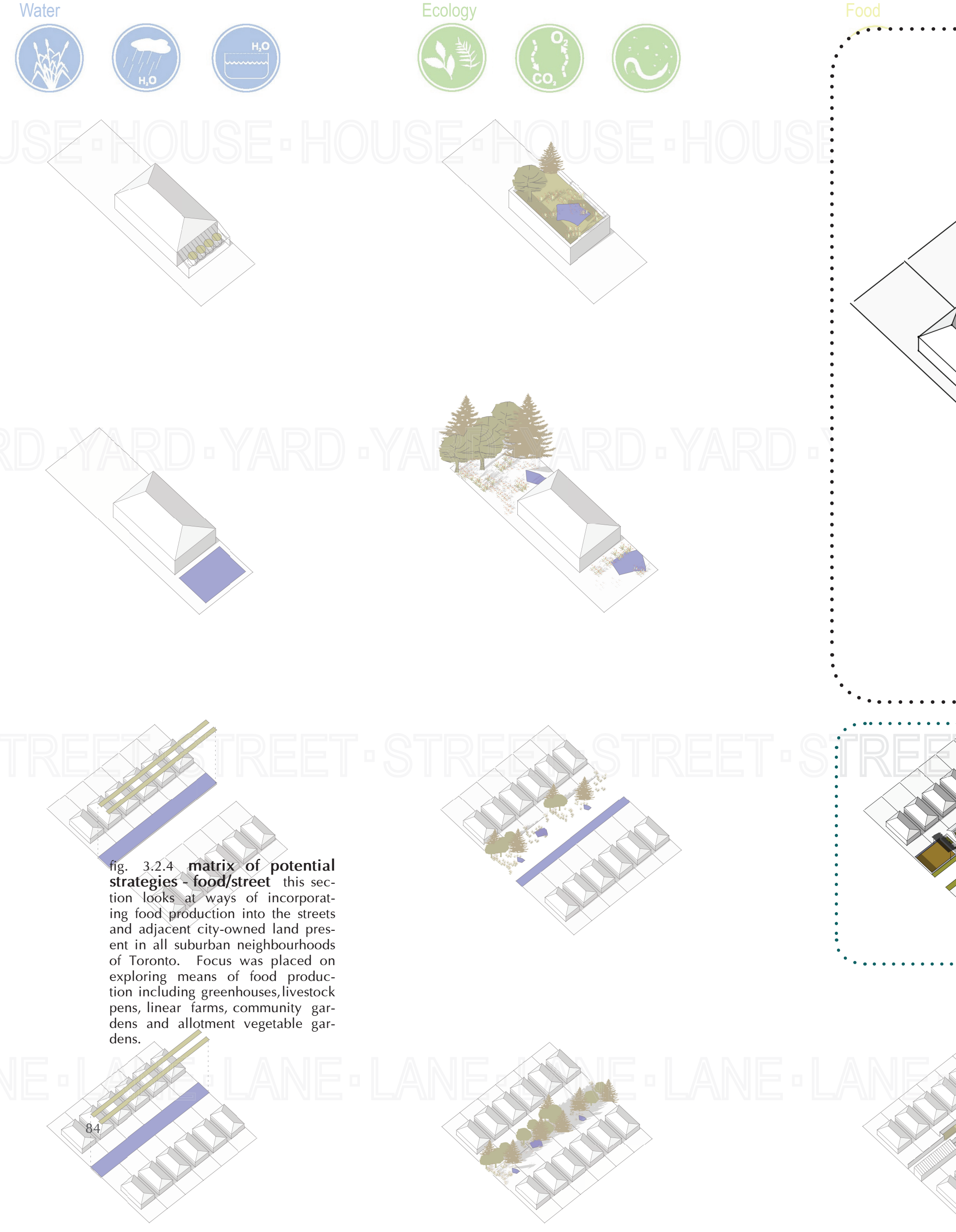
Energy

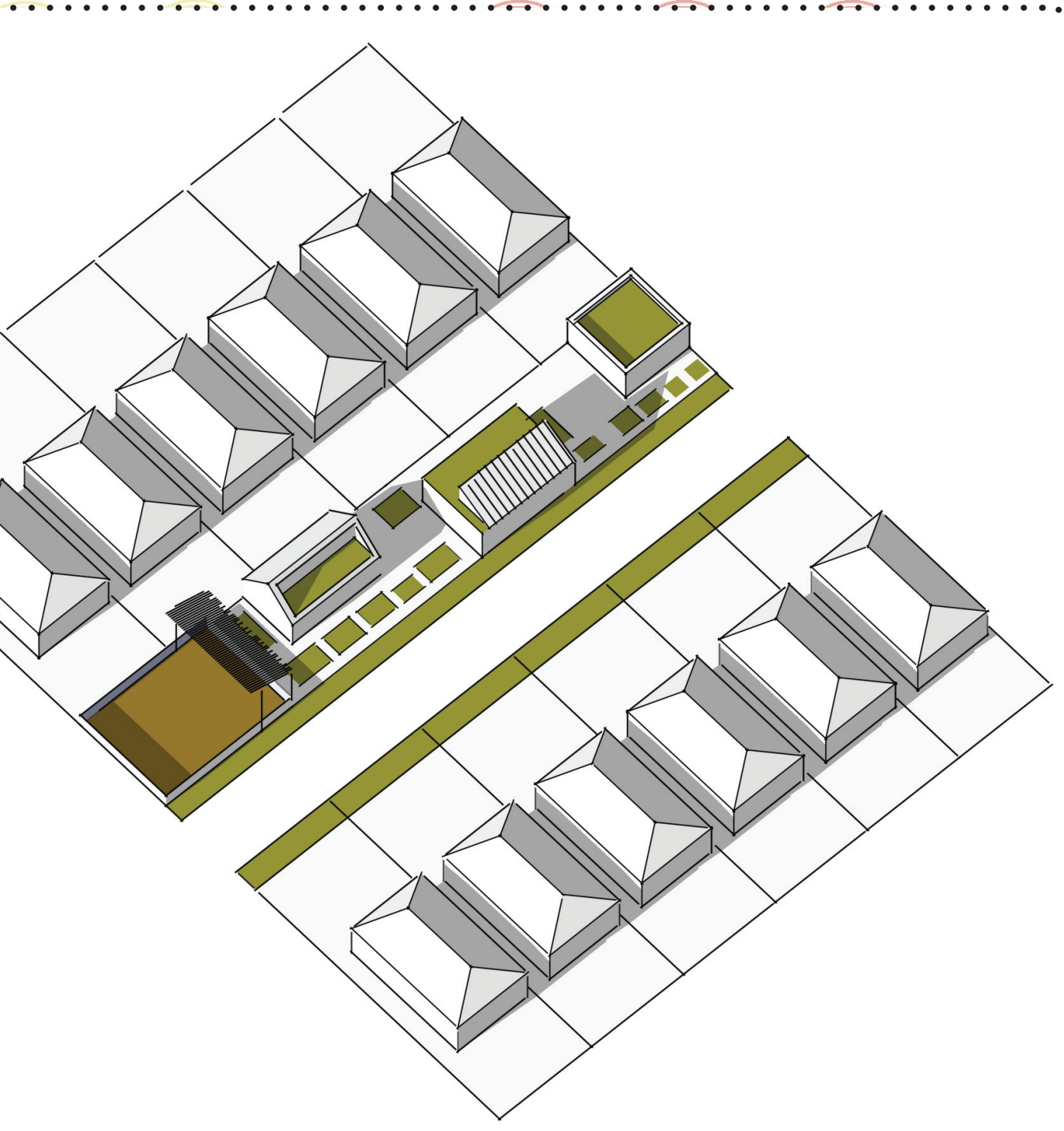

Material

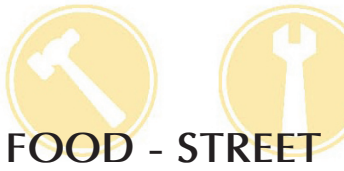

Vegetable Gardens SPIN Farming

Food Barter Systems

Greenhouse Growing

Greenroof Gardens

Food Storage Facilities

Cold Storage Facilities

Food Preparation Facilities

Food Sales (ex. Preserves)

Garden Sheds and Storage

Community Gardens

Livestock Pens (ex. Chickens)

Aquacultural Facilities

Abbatoir Facilities

Processing Facilities

Small Machinery Storage
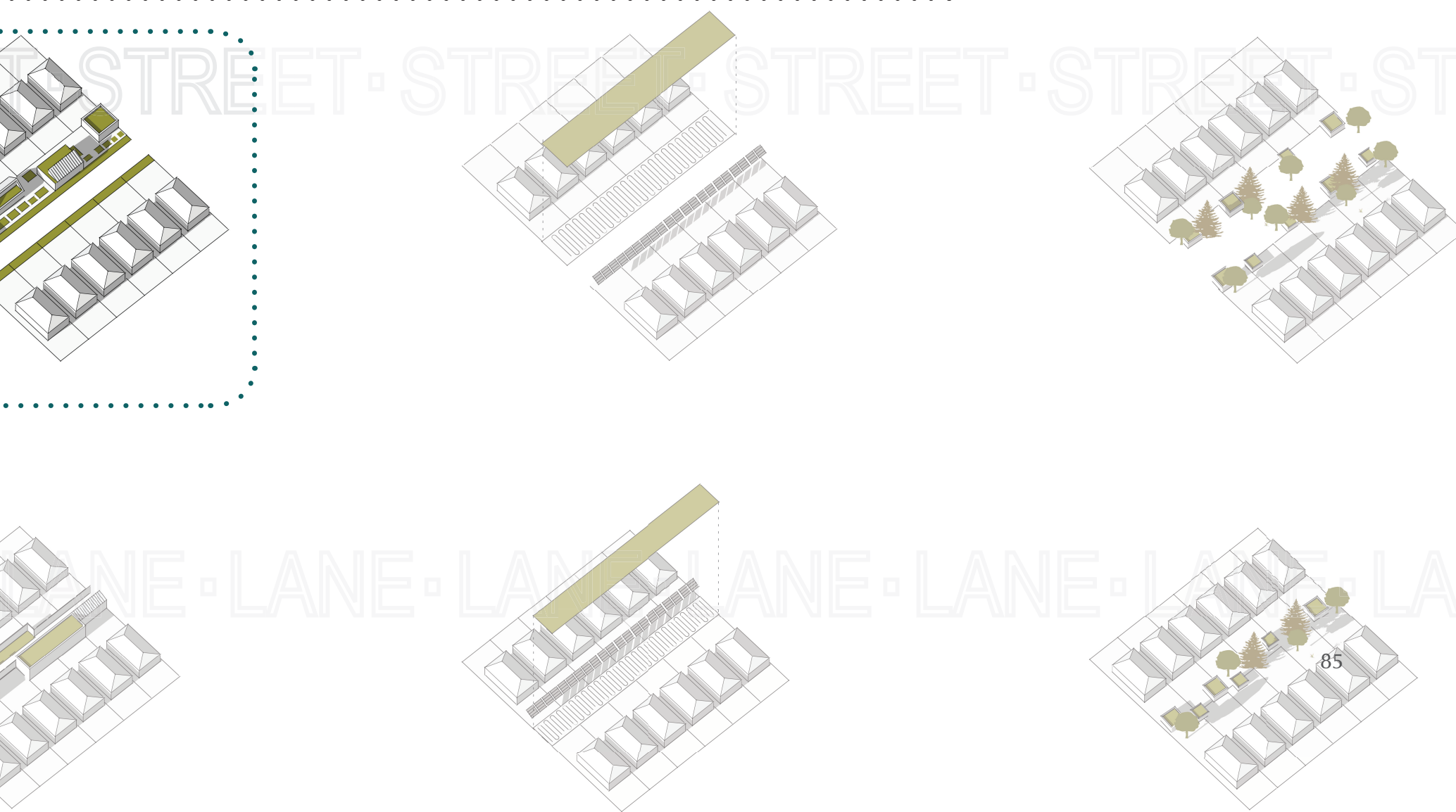
Water

(8)
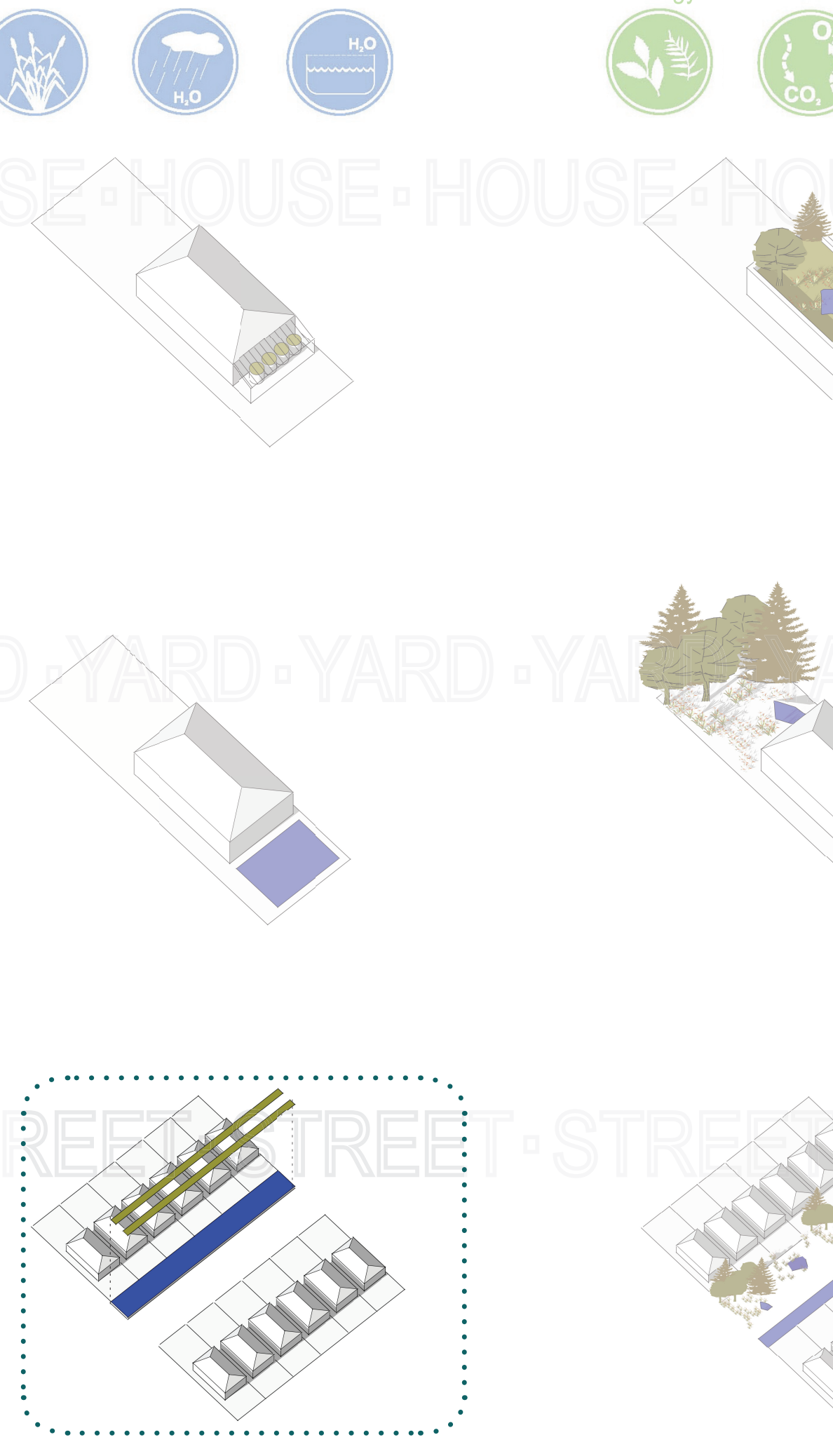

\section{Ecology \\ (4)}

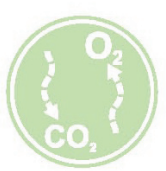

$(\because 2)$
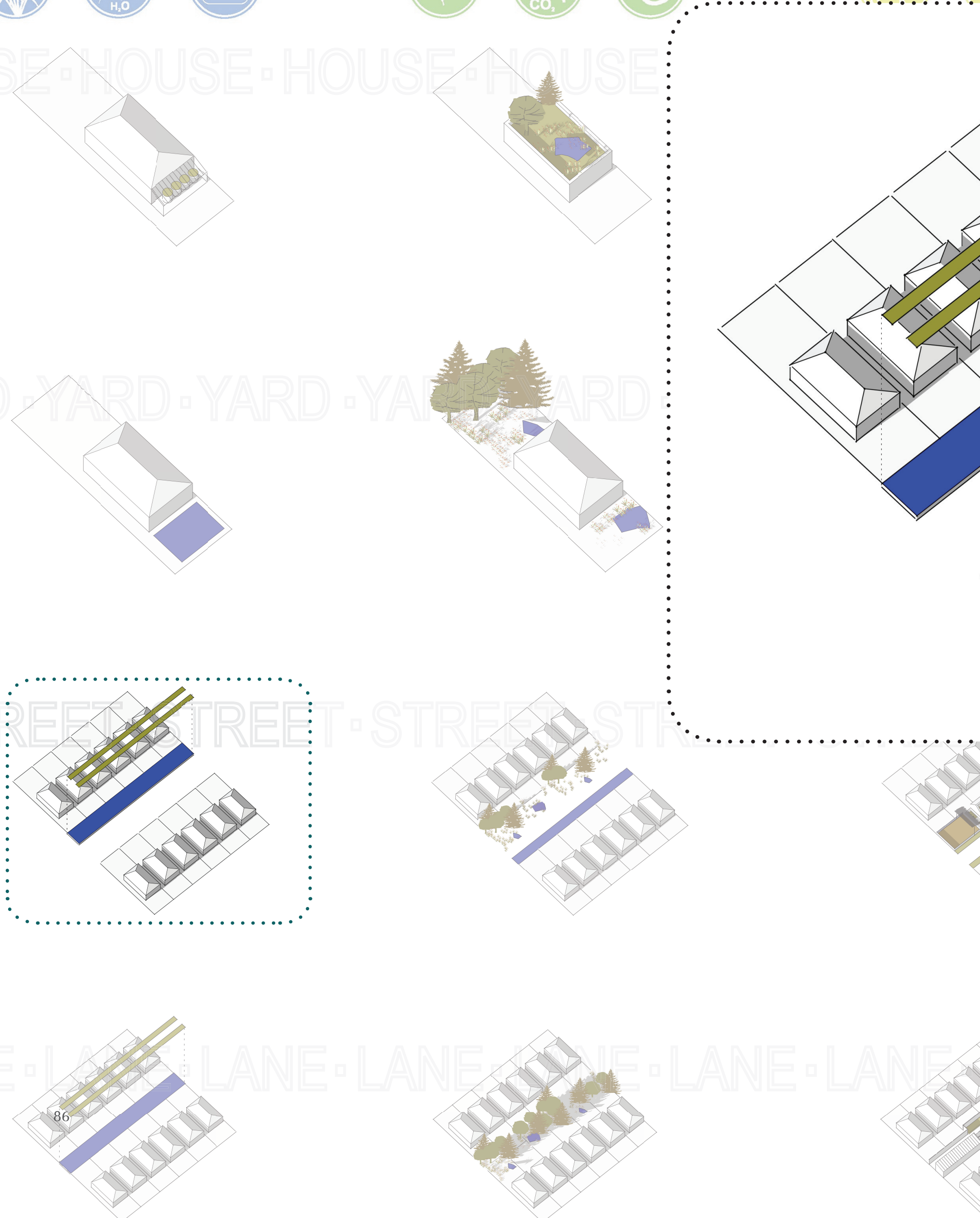


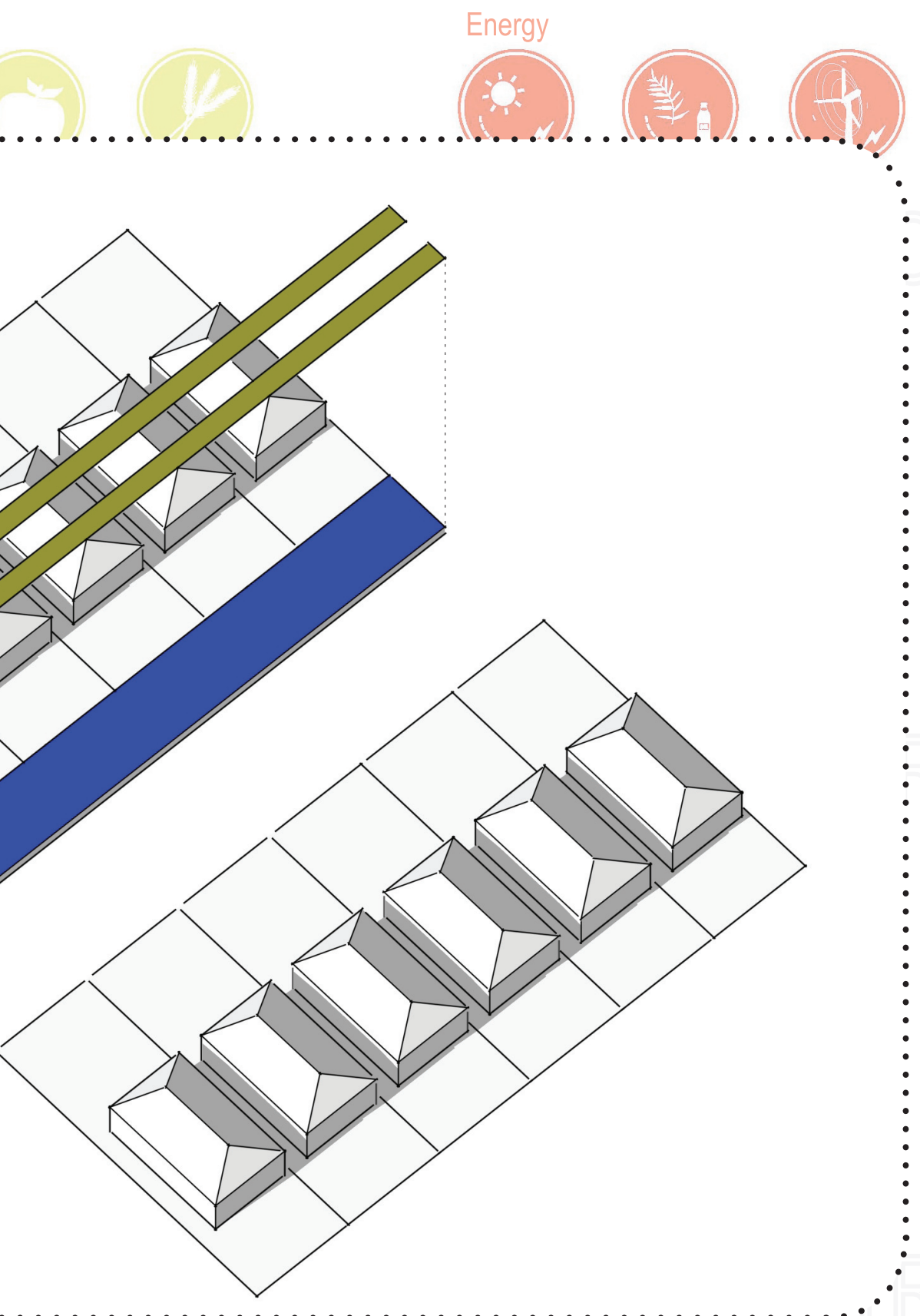

\section{WATER - STREET}

Rainwater Collection

Grey Water Treatment

Composting Toilets

Storm Water Ponds

Irrigation Systems

Heat Storage Ponds

Marshland Filtration

Native Water Plants

Wildlife Habitat

Absorptive Materials

Permeable Surfaces

Wetland Succession

fig. 3.2.5 matrix of potential strategies - water/street this section looks at ways of incorporating water collection and purificaiton into the streets of a suburban neigbourhood. Focus was placed on exploring means of water purification such as bio-swales, wetland marshes, storm water ponds and grey water filtration. 

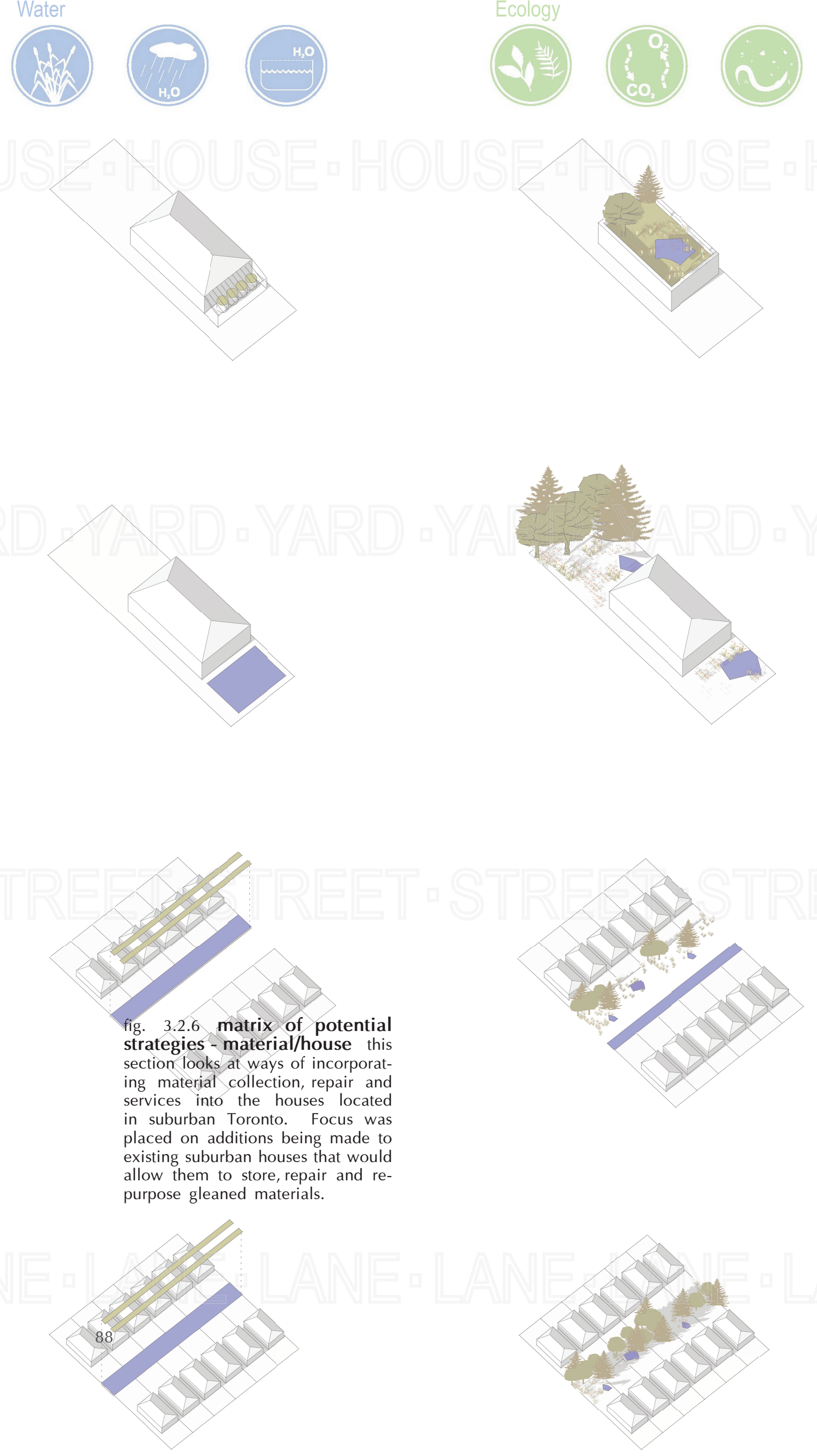

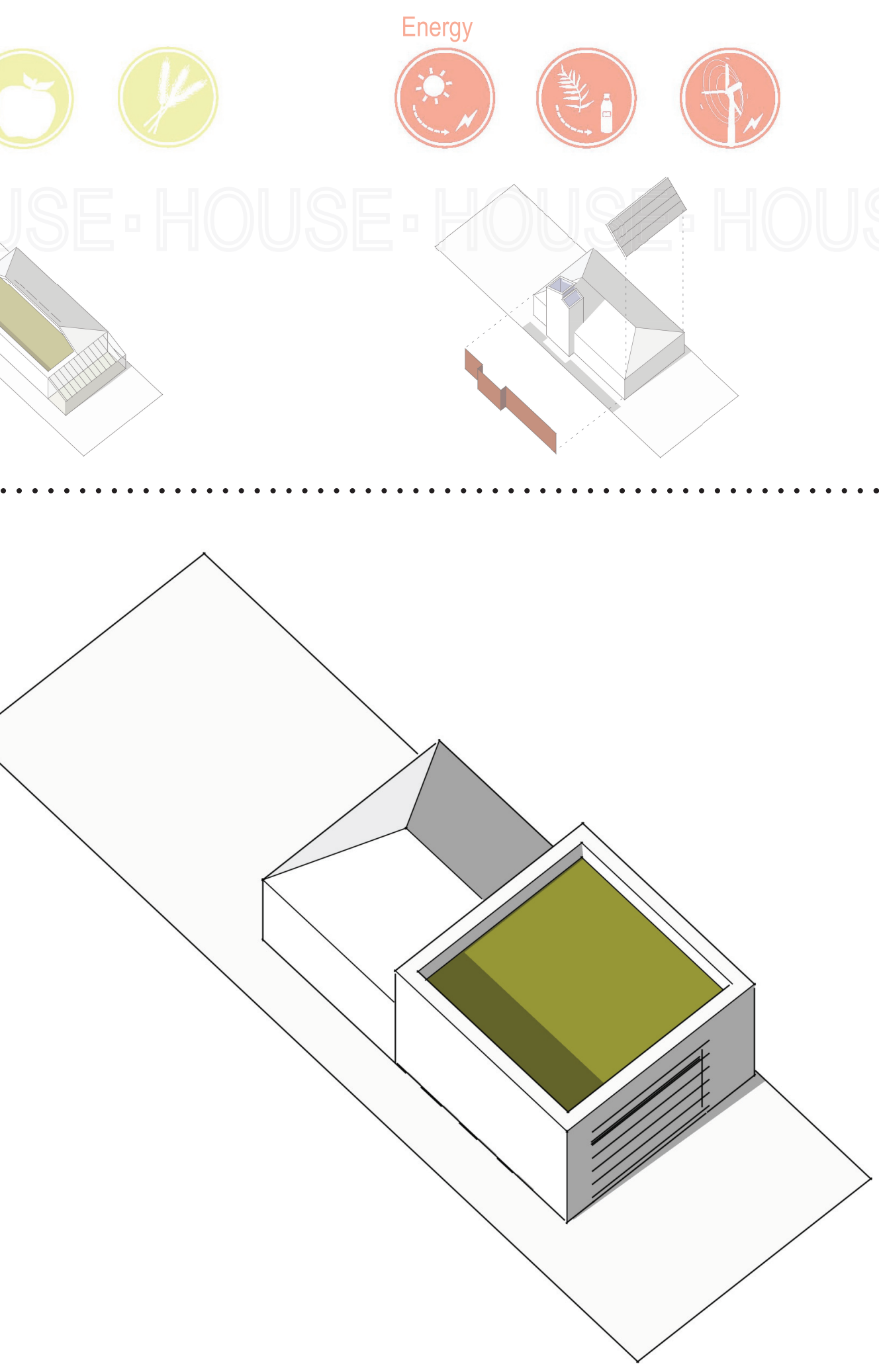

\section{MATERIAL - HOUSE}

Repair Shops

Recycling Facilities

Reclaimed Material Storage

Material Cultivation (ex. Straw)

Composting Facilities

Workshops

Tool Inventories

Retail Frontage

High Ceilings

Garage Doors

Aggregated Items

Second-Hand Shops

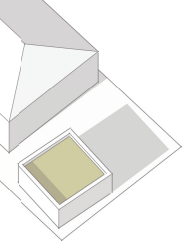


fig. 3.2.7 synergistic potential with the creation of the productivity matrix, it became clear that many of the strategies explored could be addressed in tandem. Bio-fuel production could be a bi-product of vegetable gardens or bio-swales; photo-voltaic panels would work well with repair shops; air and water remediation work in conjunction with aquacultural facilities and community gardens. There is tremendous potential for finding linkages between the various modes of productivity, as is demonstrated in the correlation diagram shown.

This infact would be the beginning of the layering of productivities mentioned earlier in the mapping exercises. 


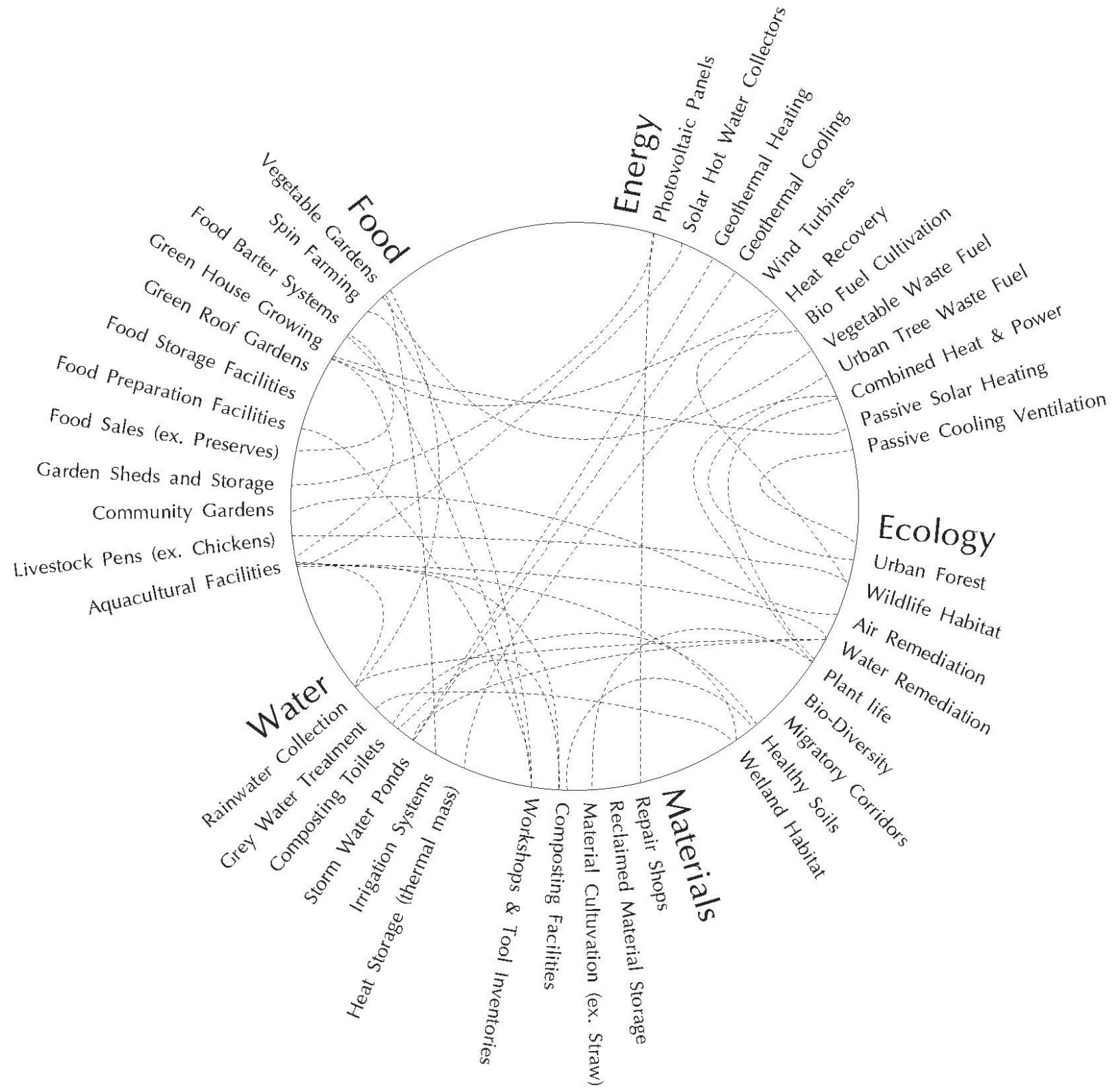




\section{4 the design exploration}


4.1 the proposal based on the DPS and Co-op models detailed earlier in this report, a proposal is made to redefine suburban Toronto. A redevelopment strategy is proposed, detailing the potential location of new buildings and landscapes within the neighbourhood known as Knob Hill. The proposal (based on the house, yard, street and lane of the productivity matrix) entails the redefinition of the suburban street into a woonerf based living street; the location of street-side community oriented buildings and landscapes; allowances for housing renovations and additions; and the creation of backyard grannyflats to house separate units and/or private offices. The amassing of these new buildings and landscapes are documented in a series of plans that describe three stages of accumulation within the proposed redevelopment strategy - $25 \%, 50 \%$, and $100 \%$ of maximum buildable area. Five detailed plans and sections are then shown, describing the potential for cohesion, interactivity, dynamism, and diverse living arrangements. This section concludes with a sequence of images documenting the potential for incremental changes to occur, based on the proposed redevelopment strategy, gradually redefining and adding to the qualities of suburban Toronto.

With the proposed redevelopment strategy, and the circumvention of suburban obsolescence through such physical redefinition, it is argued in the next section, a broader context, that these suburban neighbourhoods will be primed and ready for responding to future vulnerabilities and able to produce environments capable of reacting to feedback loops. It is argued that by allowing physical change to occur in suburban Toronto, neighbourhoods such as Knob Hill will become responsive terrains able to address future crises; landscapes on which to apply the strategies outlined in the productivity matrix.
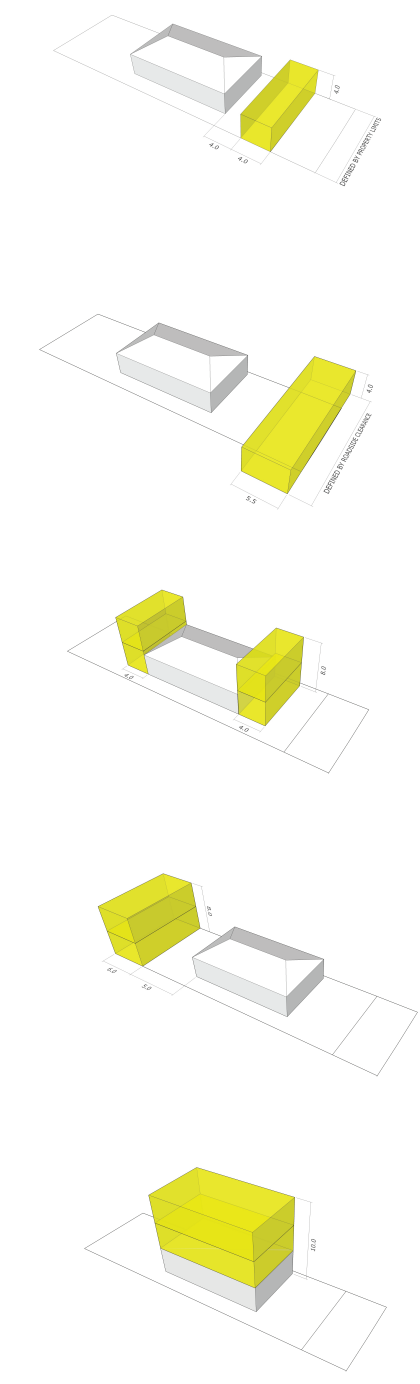

fig. 4.1.1 early explorations into regulatory changes a series of sketches examining the potential location and parameters of new buildings and additions to be added to a typical suburban lot in Toronto. 


\section{高要要}

fig. 4.1.2 plan of existing Knob Hill block

fig. 4.1.3 framework for redefining Knob Hill block the framework for the redevelopment strategy is shown, indicating the various components of the proposal. A maximum allowable building area is proposed to prevent neighbourhoods such as Knob Hill from being over-developed or replaced with overly dense living arrangements. It was argued earlier that these low density suburban neighbourhoods have a vital role to play in providing productive landscapes for the city of Toronto. The maximum building area shown is a means of allowing for incremental densification within a limited scope of development - a limit that ensures these neighbourhoods maintain their essential qualities (privacy, greenspace, human scale, child-safe streets, etc.) and maintain their ability to recreate their landscapes into productive grounds.

It is argued that a limit of $50 \%$ of the streetside, city-owned lots, may be built upon, with the remainder being used as productive landscapes (water, ecology, food, energy, material); a maximum of $30 \%$ can be added to existing houses (approximately 700sqft extensions); and every lot can add two storey grannyflats to the back of the lots $(100 \%)$.

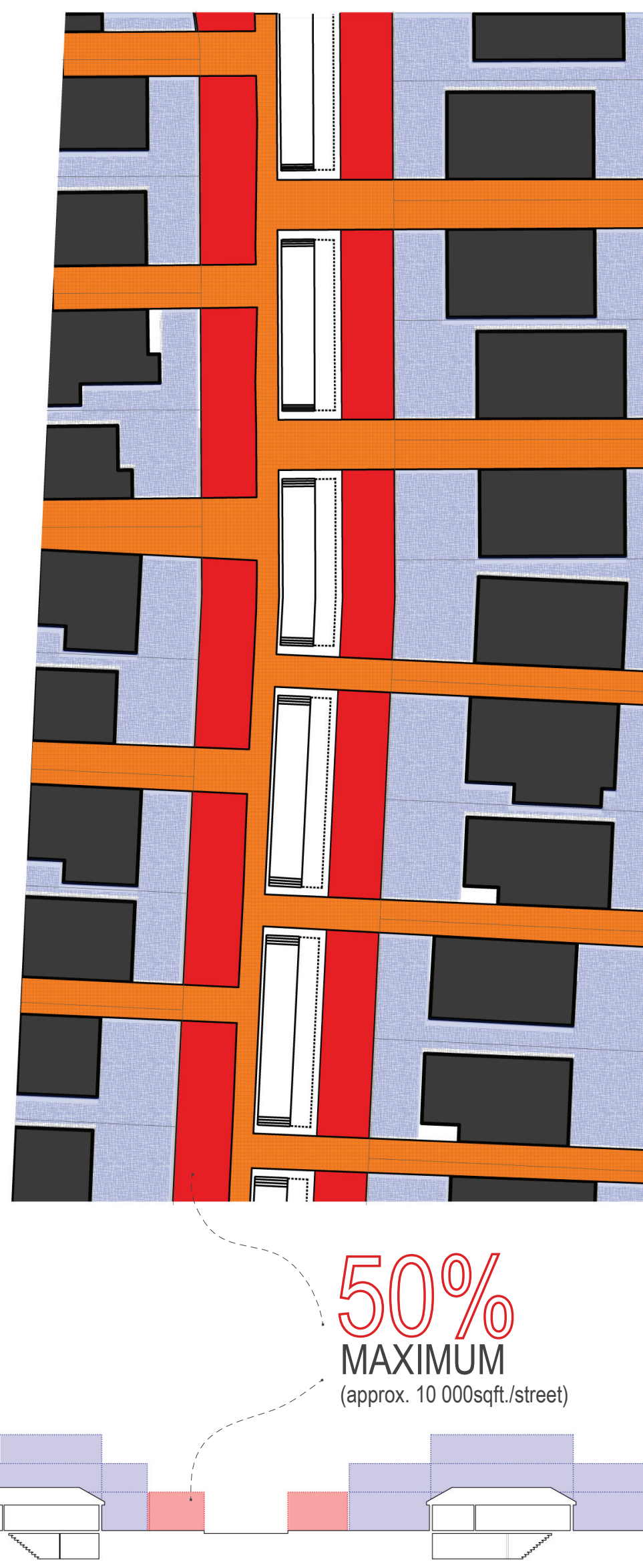




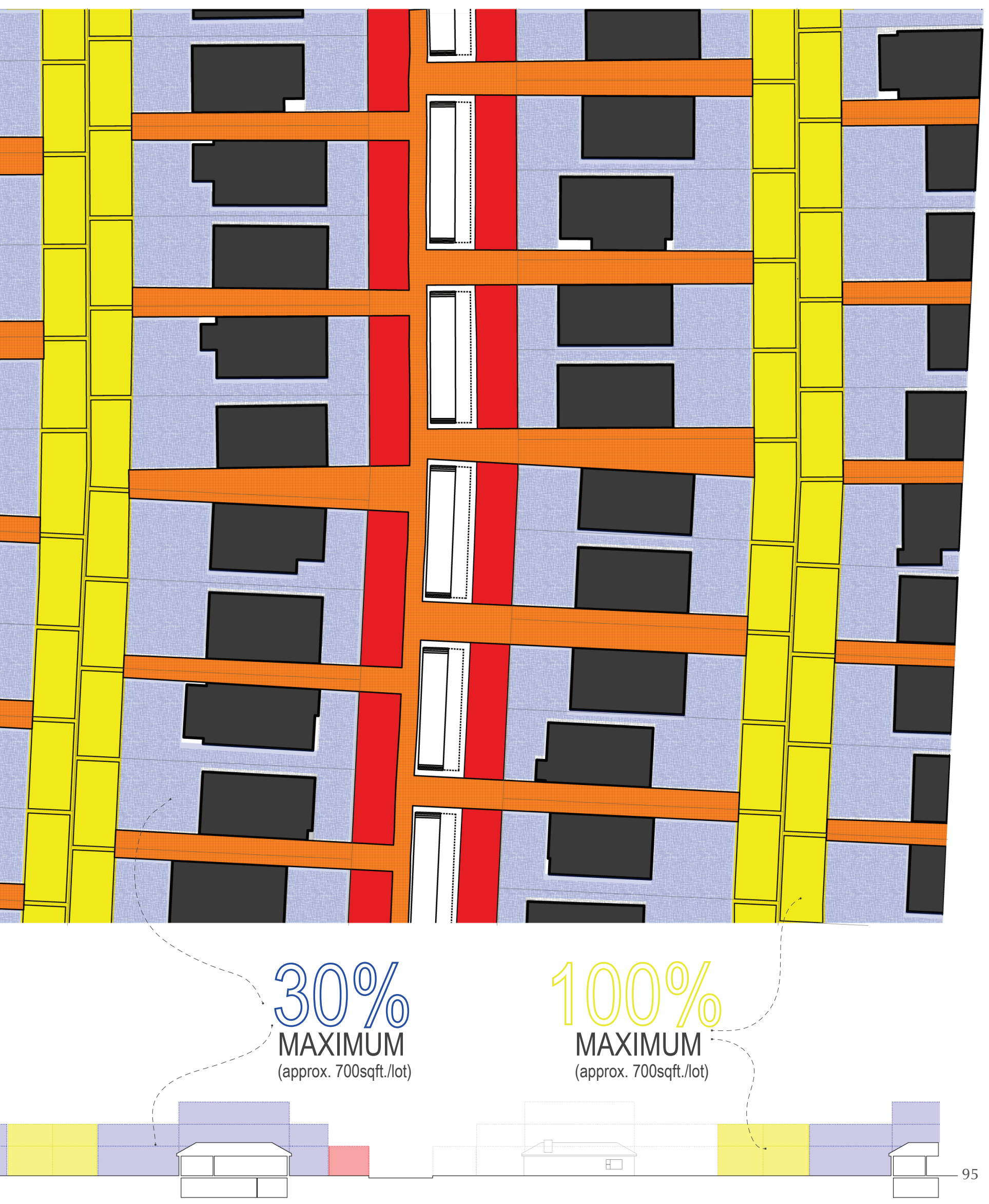


fig. 4.1.4 woonerf layout (public/private interface) the layout of the proposed woonerf is shown. A woonerf allows for pedestrian and bicycle inhabitation of the street, but is also used here to reorient the entrances of each home. Branching out from the woonerf are shared paths leading to the side yards of the houses; the entrances and the backyard areas of each lot. As will be discussed later, this encourages interaction within the neighbourhood.

\section{opposite}

fig. 4.1.5 street side layout (public) in every suburban neighbourhood in Toronto, street side setbacks exist (averaging approx. 6 meters in width). This street side land is city-owned and, it is argued, could be used in the renewal of Toronto's suburbs - used as public community space and outbuildings, as well as productive landscape

fig. 4.1.6 granny flat layout (private) the location of backyard grannyflat outbuildings is shown. It is argued that each home would be permitted to build a two storey grannyflat at the back of their lot with an average footprint of 700sqft.

\section{opposite}

fig. 4.1.7 house additions layout (private) in addition to grannyflats and street side outbuildings, additions to the existing houses would be permitted. It is argued that such extensions could be made anywhere on the lot, but should be limited to $30 \%$ (approx. 700sqft.) of the remaining landscape. In this way, additions could be used to add new units to the existing houses, to add to the existing sq. footage, or to link the existing houses to the grannyflats or streetside outbuildings.
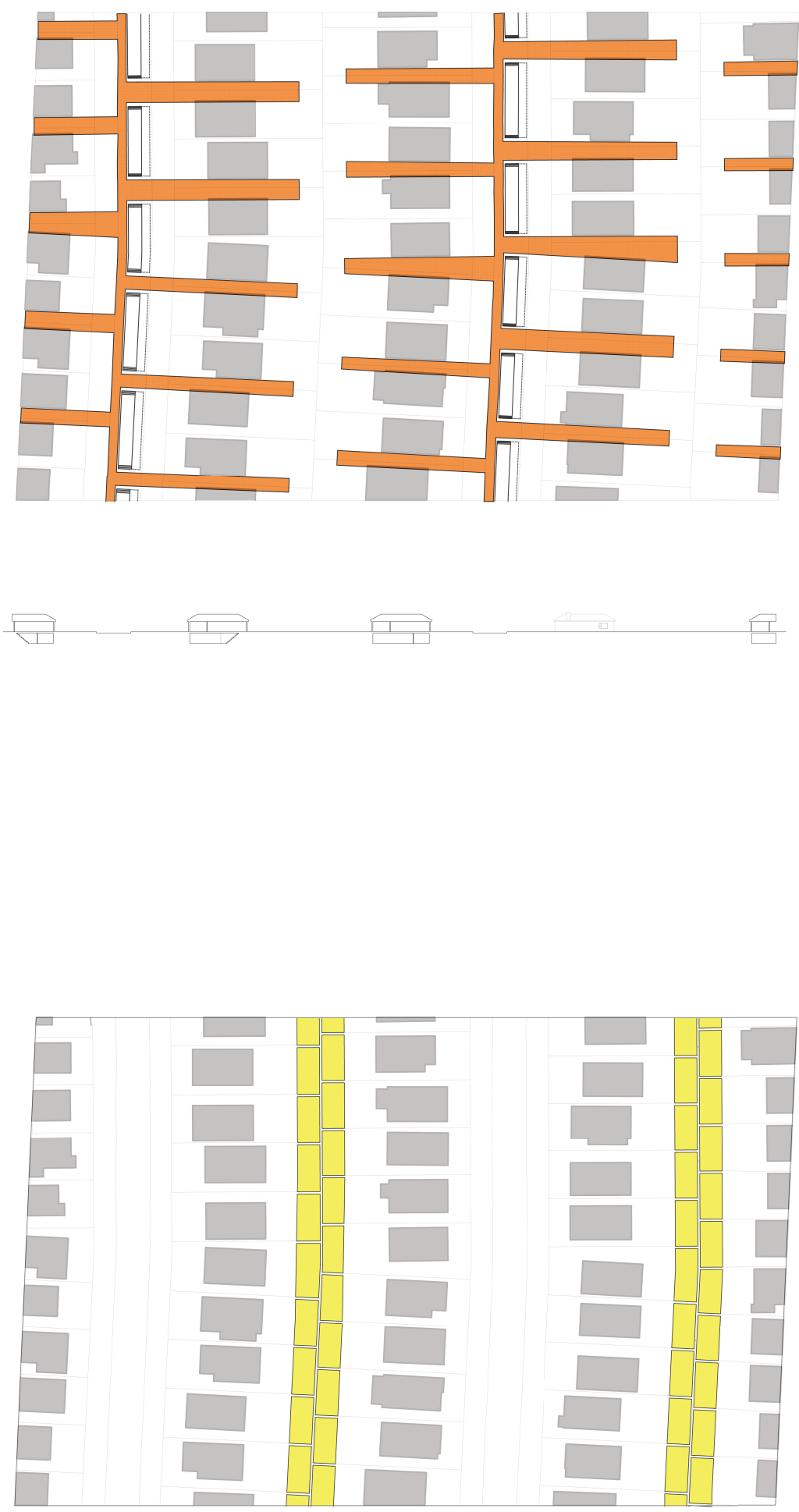

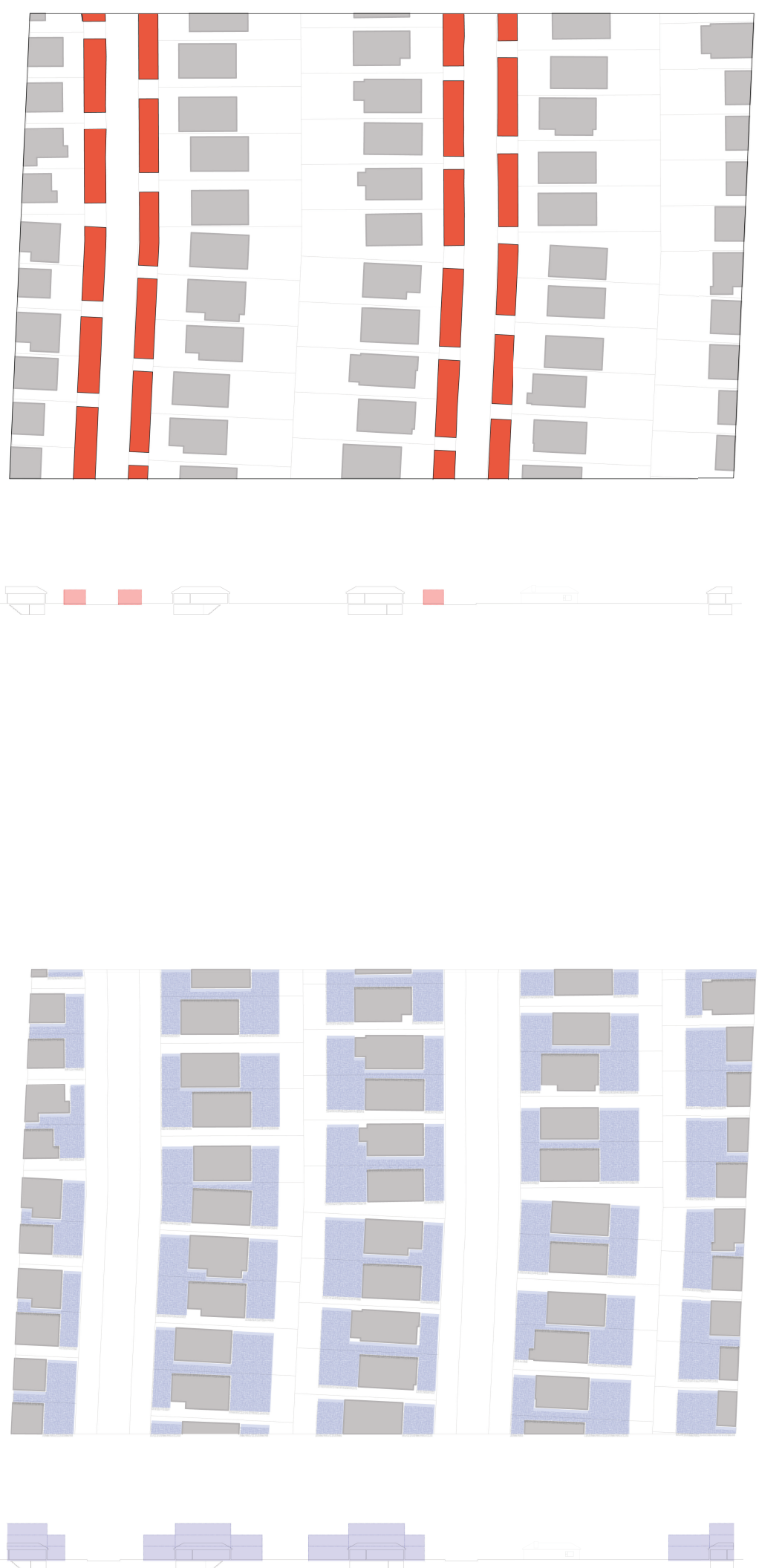

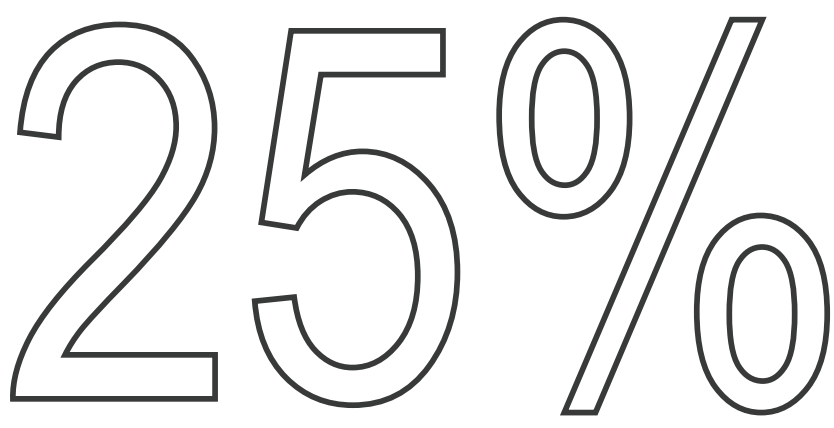

Of The Maximum Buildable Area

fig. $4.1 .8 \quad 25 \%$ of maximum buildable area seen as a framework for redevelopment that will be built upon over a number of years, this image demonstrates a pattern that may emerge based on 25\% of the maximum allowable building area. In other words, $25 \%$ of all the houses shown have built a grannyflat at the rear of the lot and a 700sqft. addition to the existing house. Likewise, $25 \%$ of the possible locations for street side outbuildings are built.
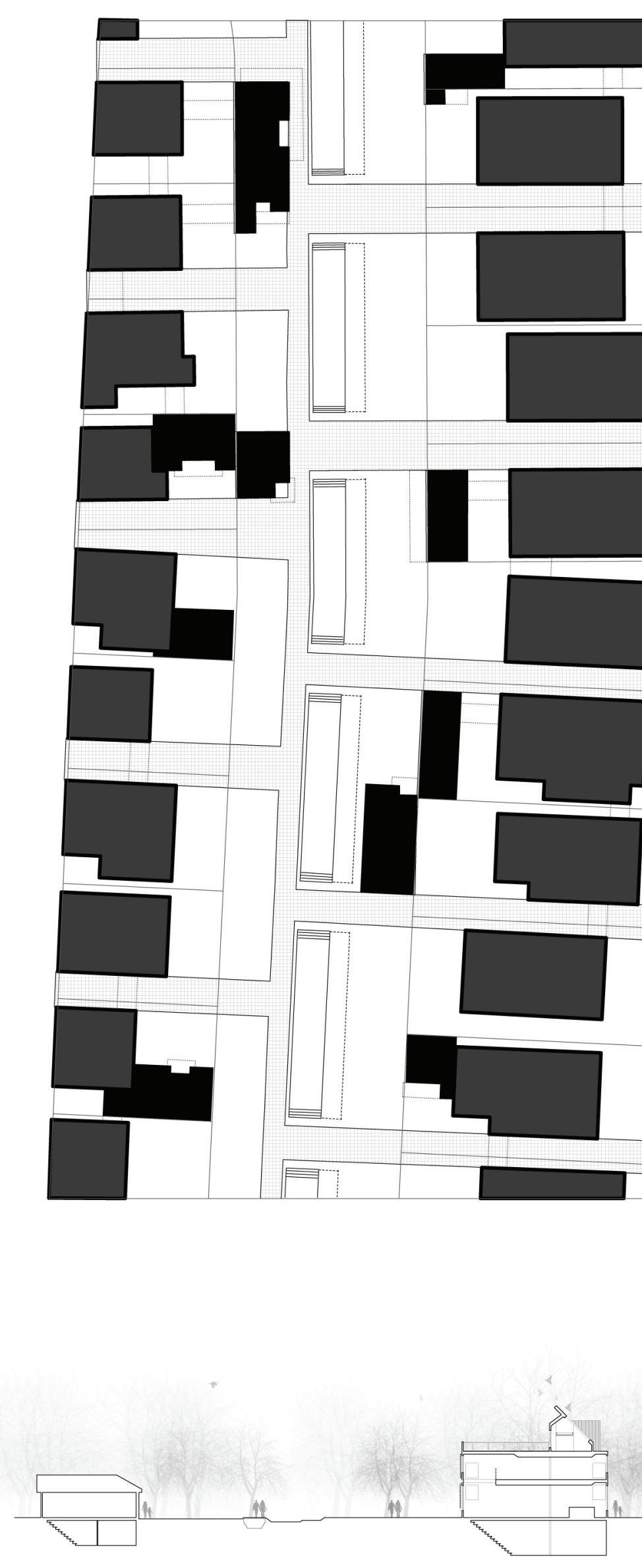


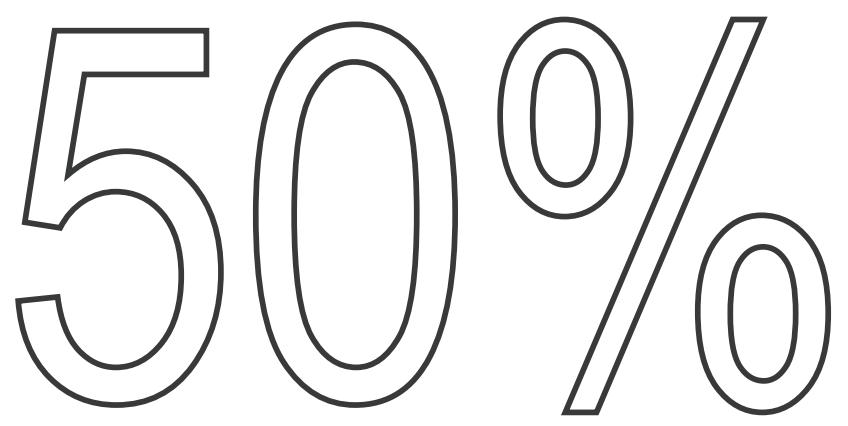

Of The Maximum Buildable Area

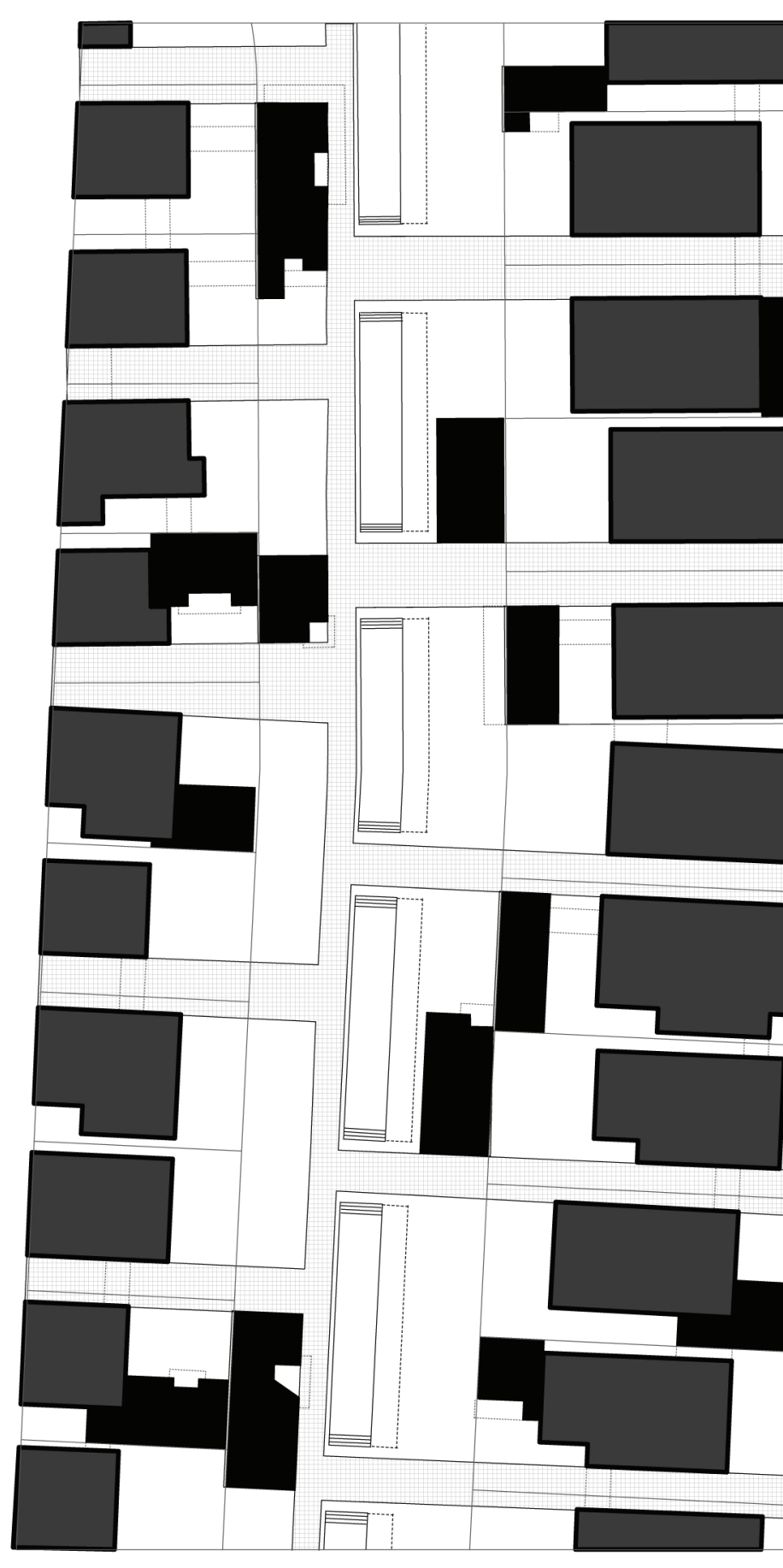

fig. $4.1 .9 \quad 50 \%$ of maximum buildable area at a later stage in the redevelopment strategy, 50\% of all the houses shown have built a grannyflat at the rear of the lot and a 700sqft. addition to the existing house. Likewise, $50 \%$ of the possible locations for street side outbuildings are built.

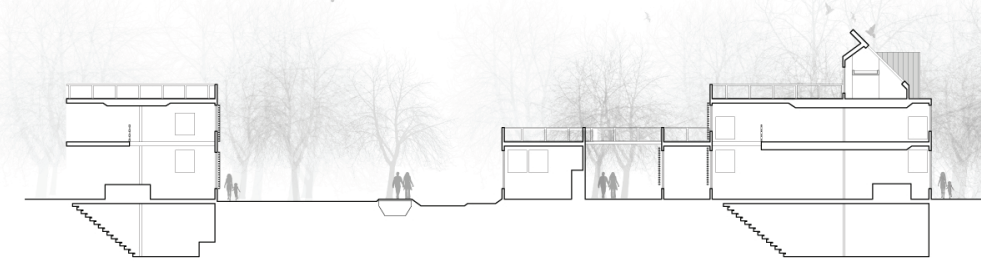



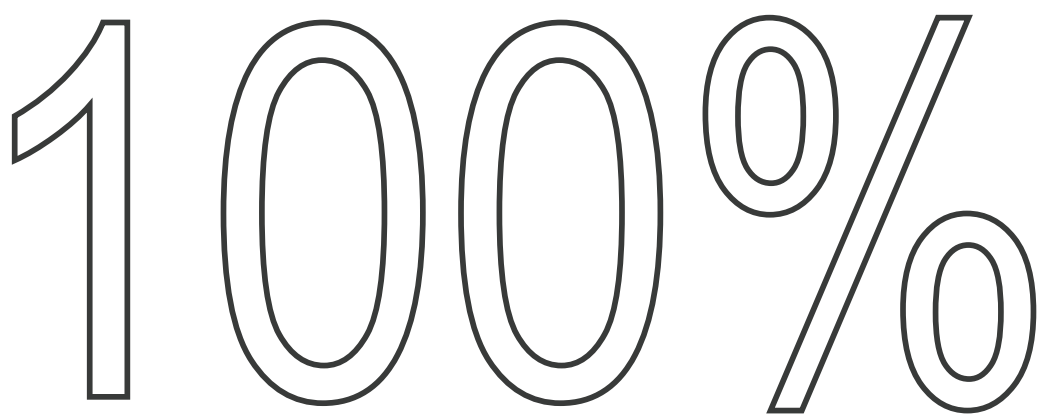

\section{Of The Maximum Buildable Area}

fig. $4.1 .10 \quad 100 \%$ of maximum buildable area at an even later stage in the redevelopment strategy, $100 \%$ of all the houses shown have built a grannyflat at the rear of the lot and a 700sqft. addition to the existing house. Likewise, $100 \%$ of the possible locations for street side outbuildings are built. As is shown, density has been added to this neighbourhood but the landscape is still very prominent and is able, through the limitations on development, to become productive grounds. Likewise, as shall be demonstrated next, the qualities of this suburban neighbourhood (privacy, green space, child-safe streets, human scale, etc.) is maintained and added to.
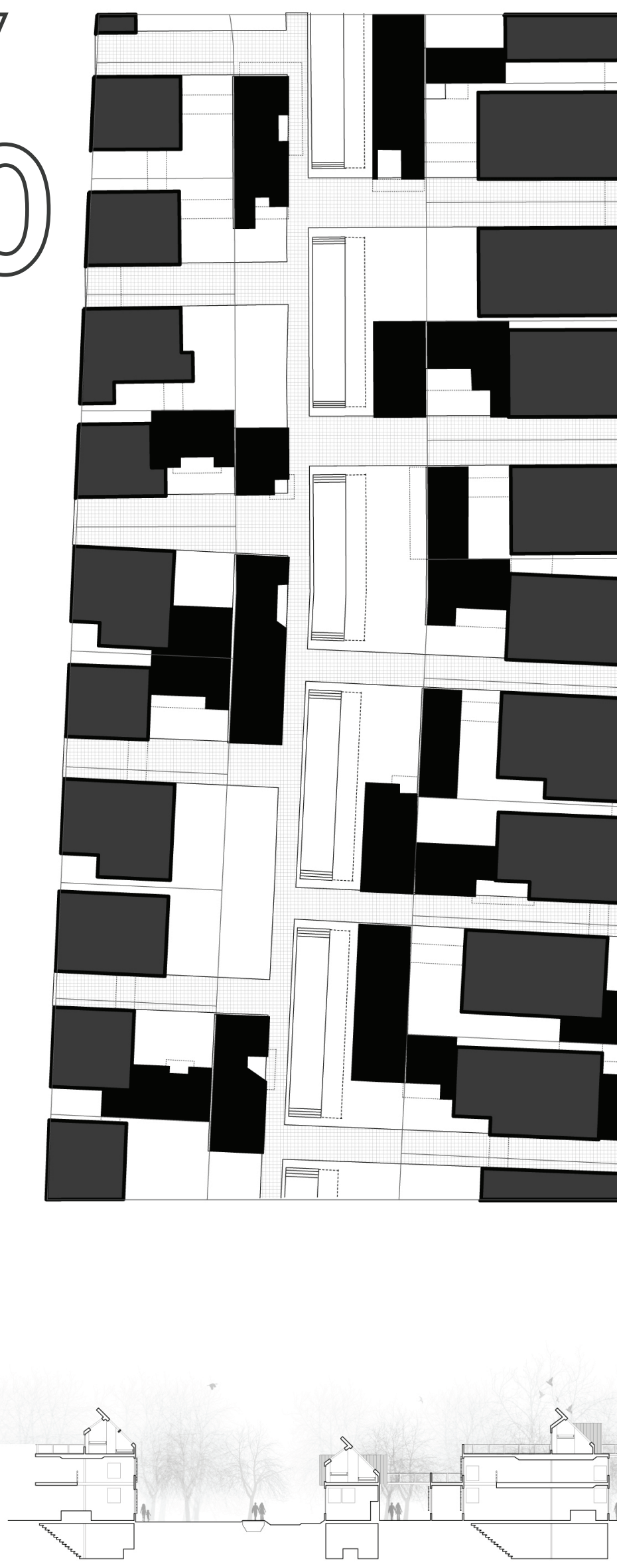

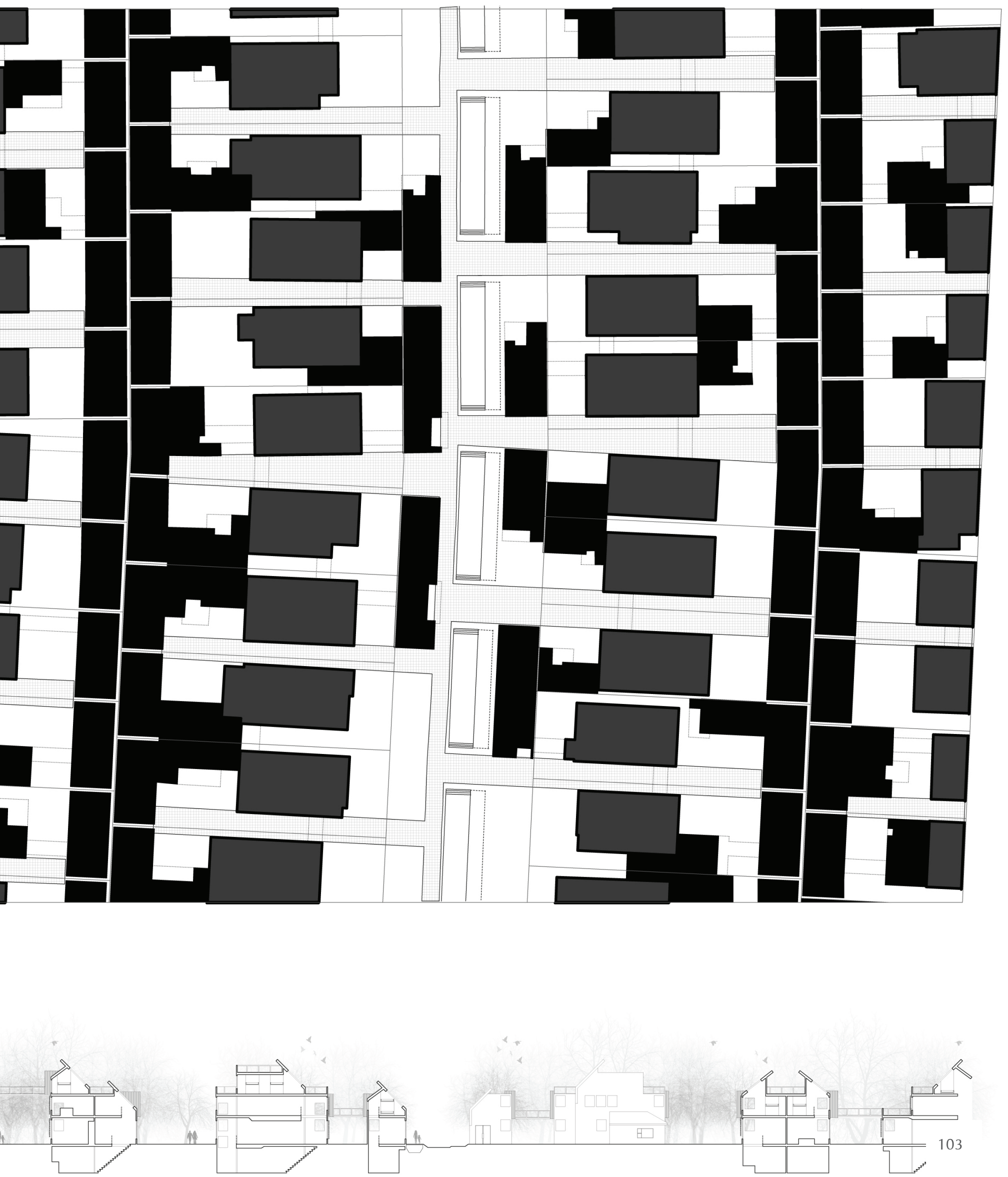


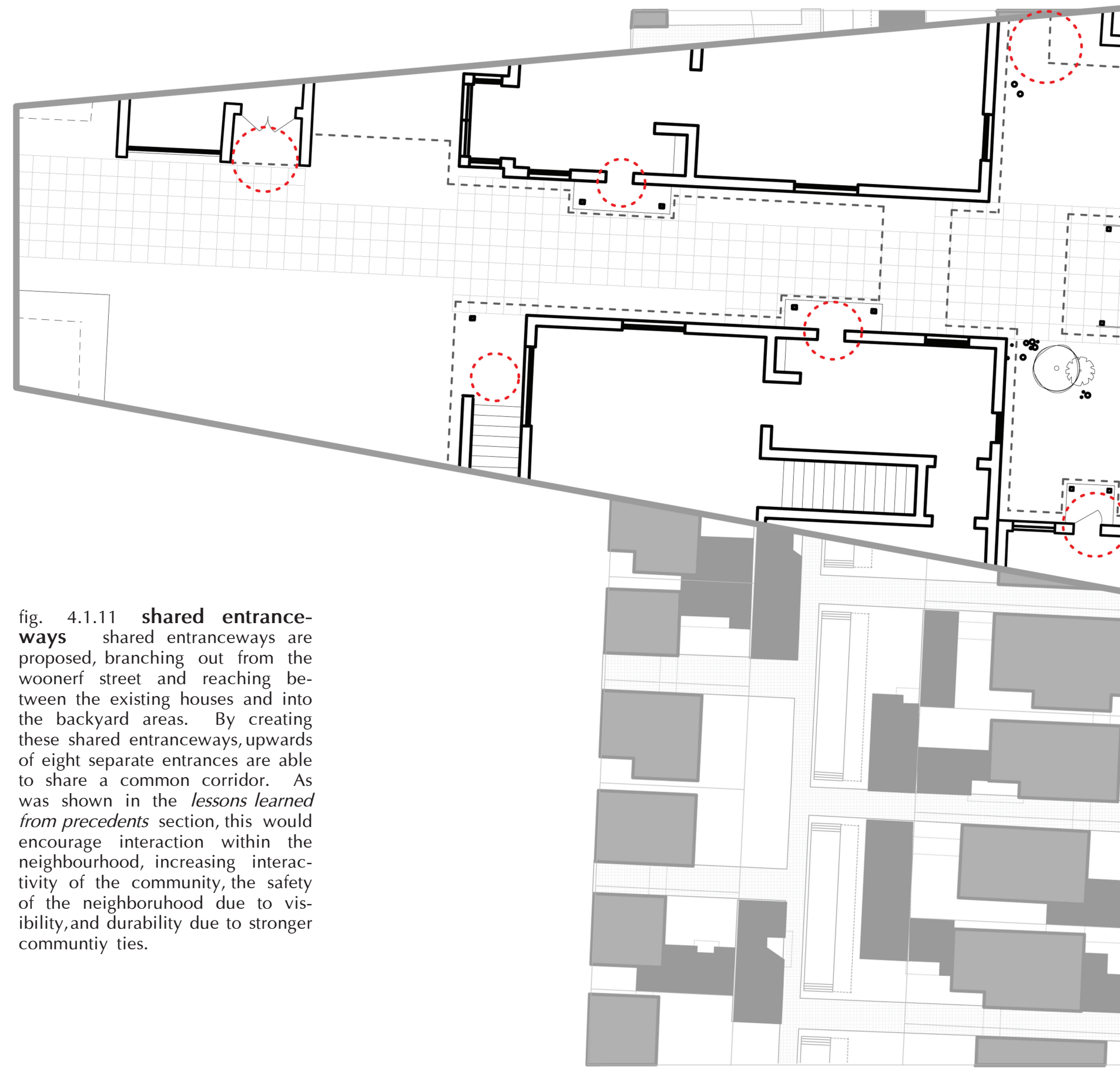




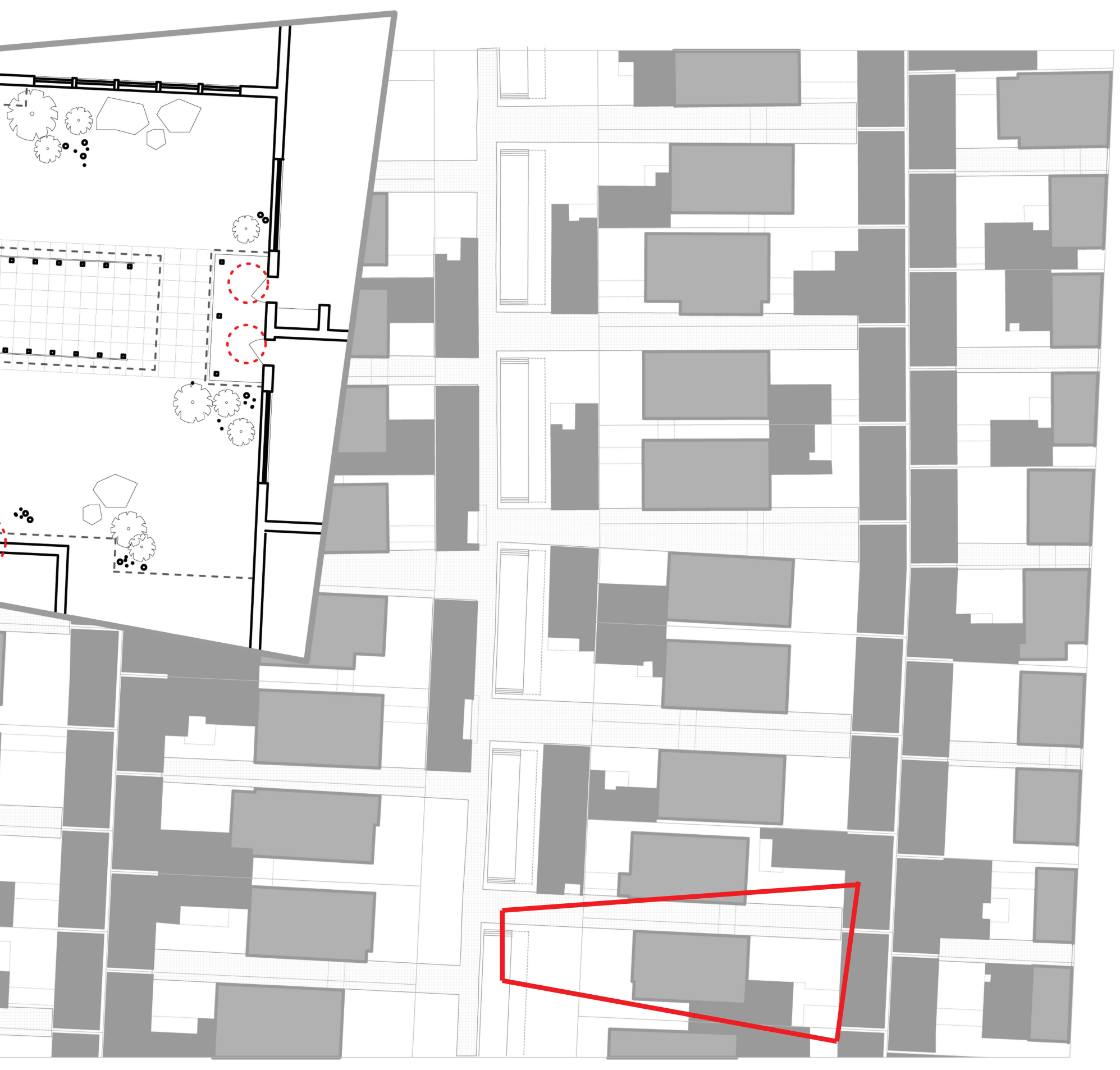


fig. 4.1.12 overhead connections there is great potential within the redevelopment strategy to create connections on multiple levels. Shared entranceways are one way of creating such connections, there is also potential to link buildings on upper levels, as is shown. This could be instrumental in the creation of linked productivity (ex. greenhouses shown), allowing for work to be done on the roofs of neighbourhood buildings with bridging connecting upper levels.
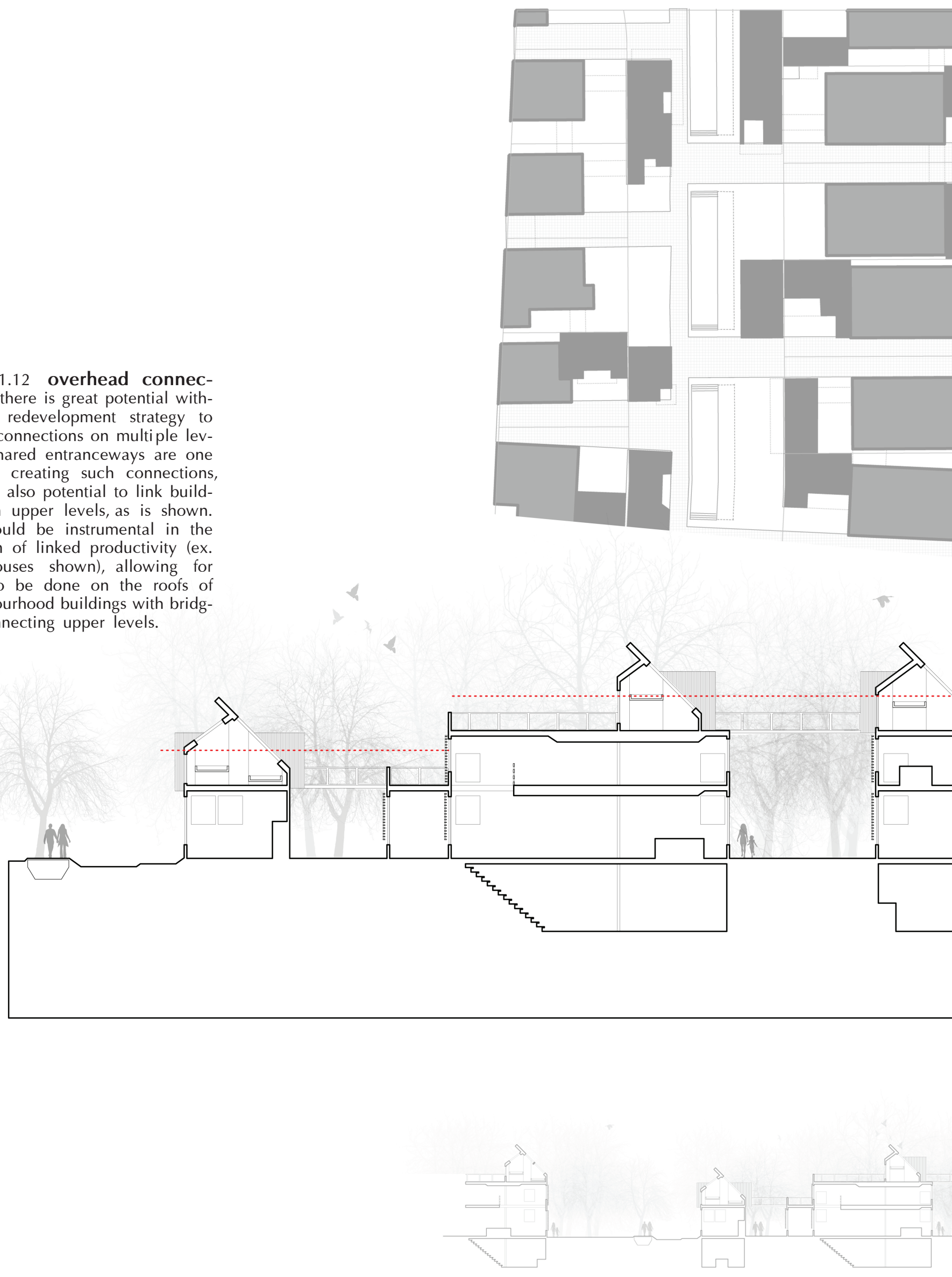


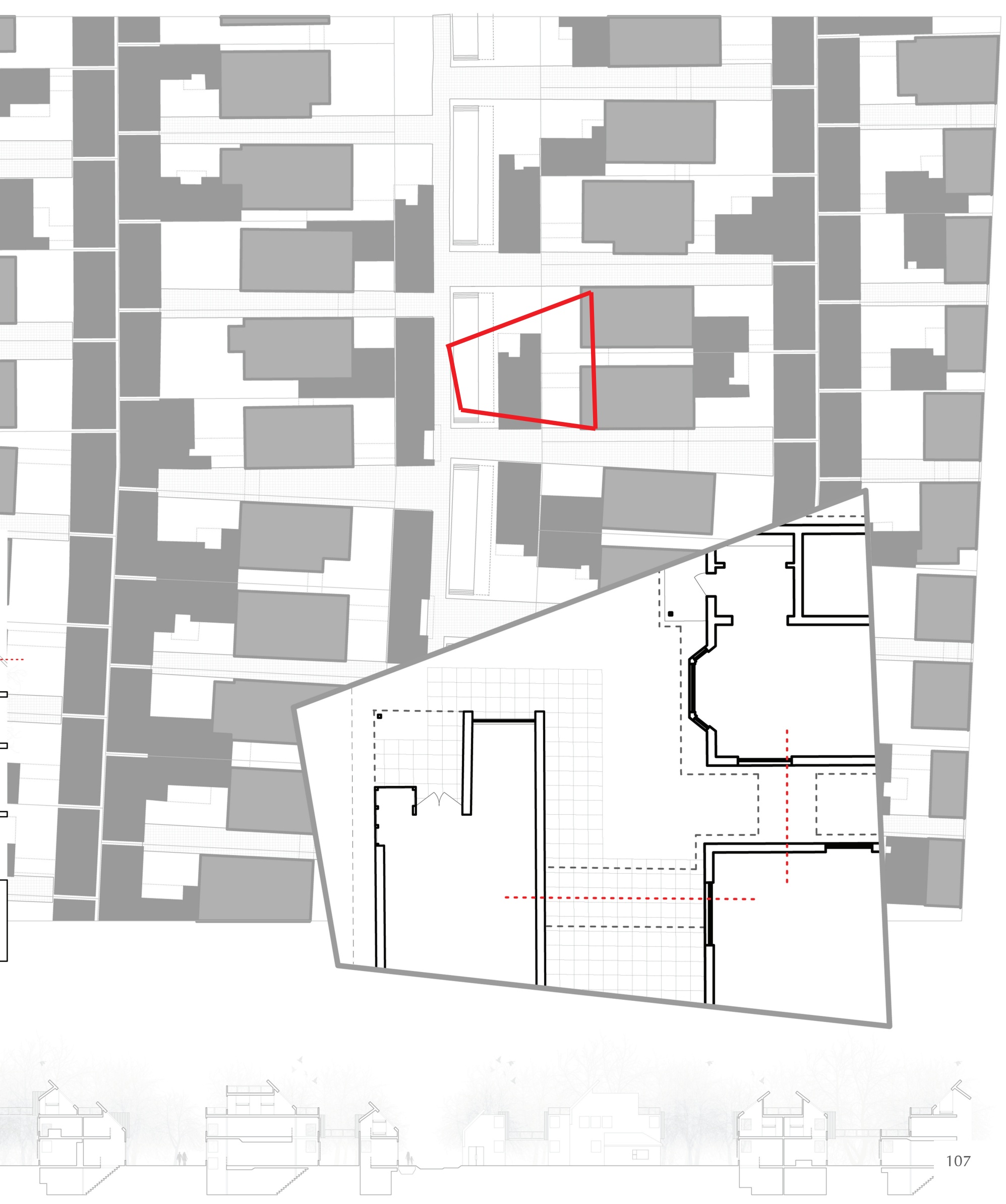


fig. 4.1.13 building linkages in addition to linkages being made between entrances and upper levels, there is also potential for making linkages between seperate buildings. Shown is the connection between three grannyflat buildings, allowing for the creation of continuous space - appropriate space for larger offices or productive activities such as repair shops, food preservation, or material storage.

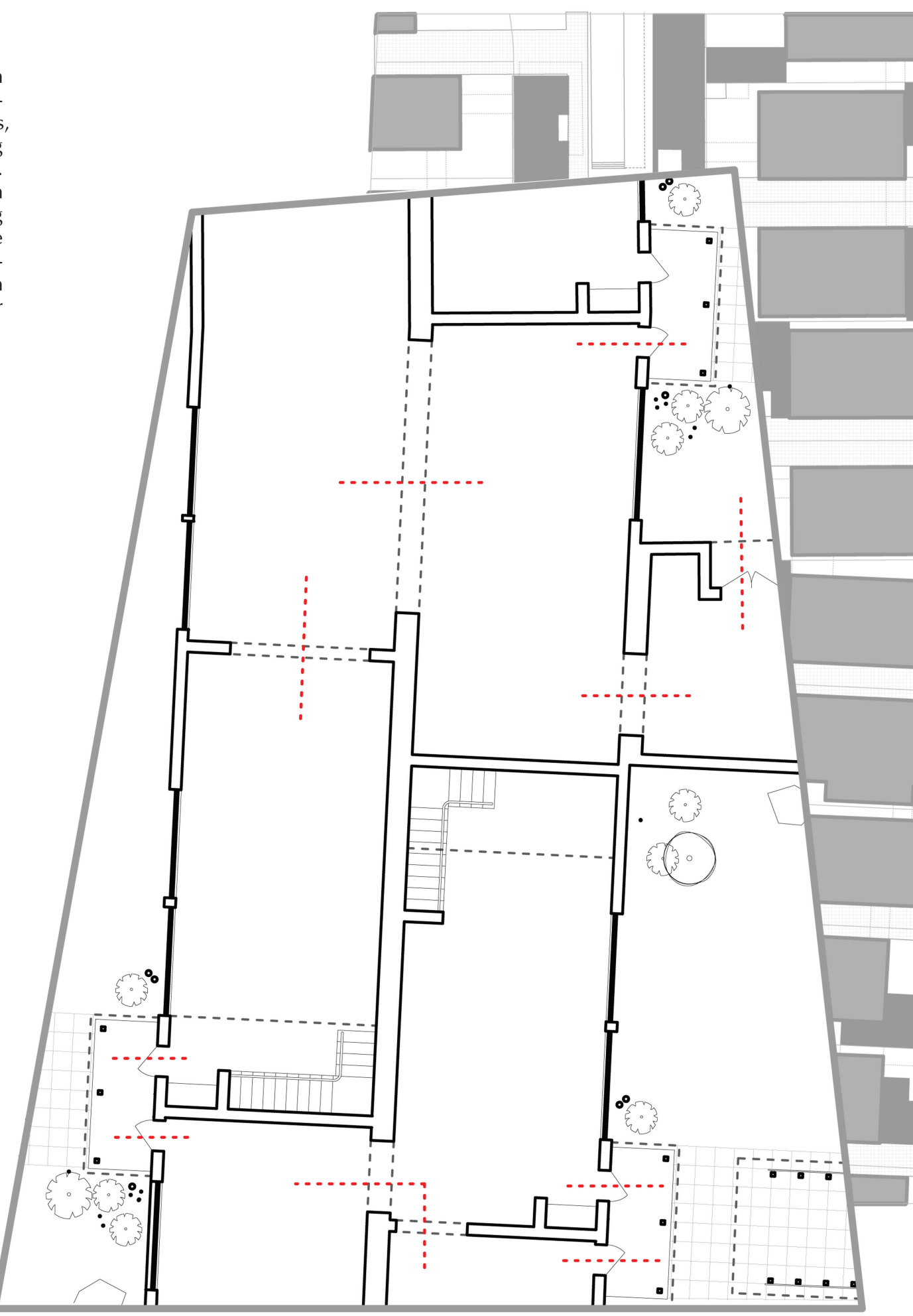




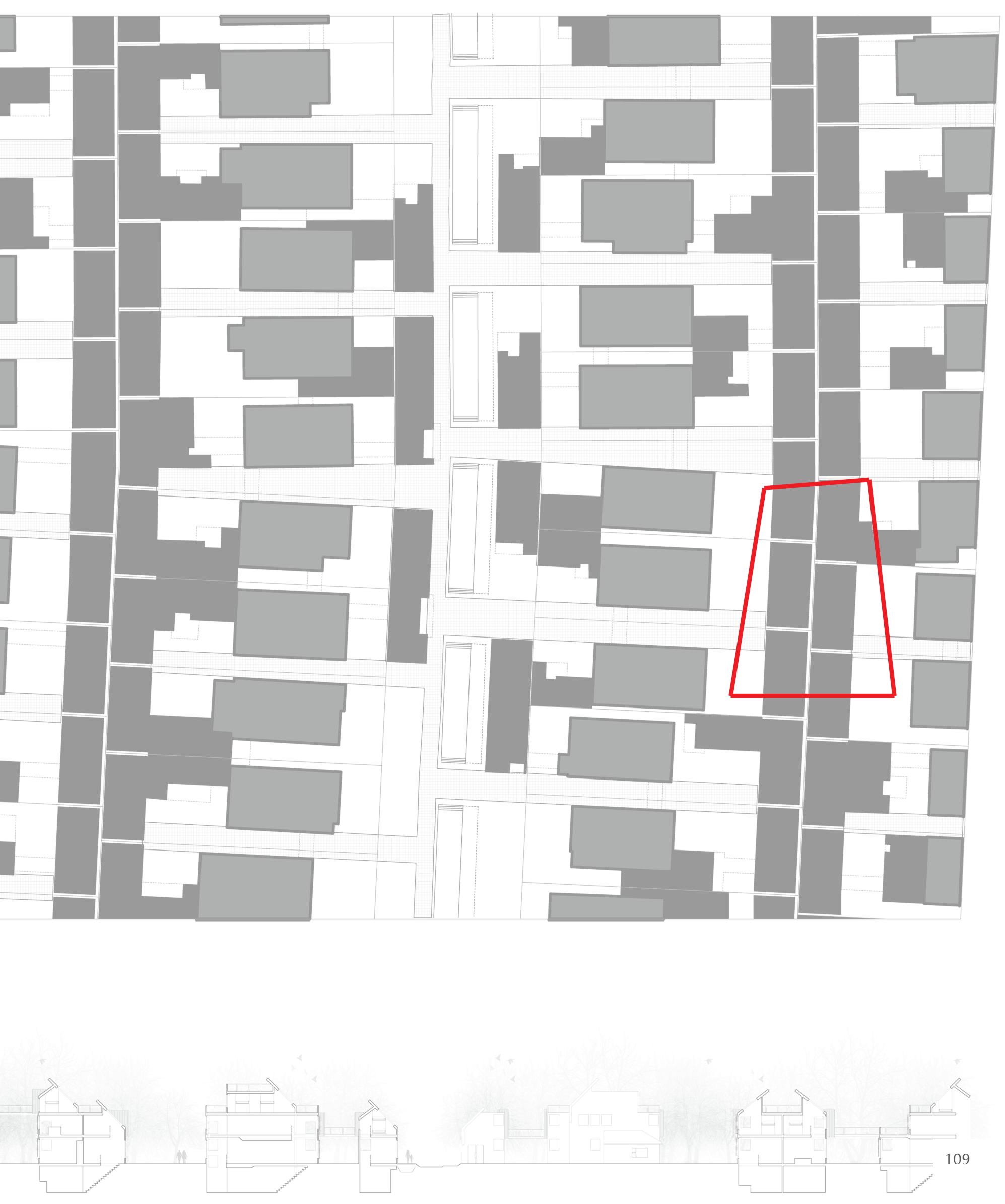




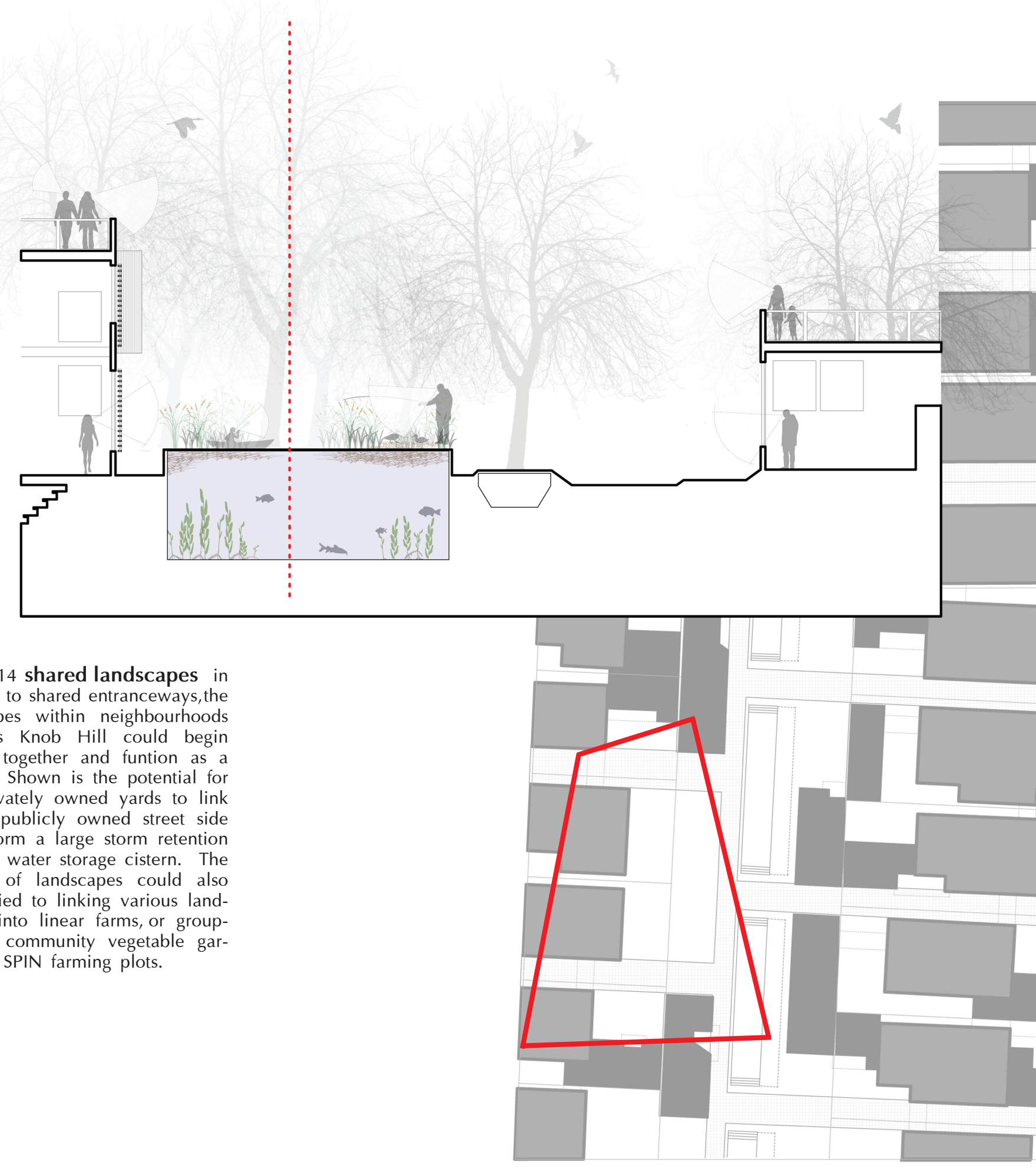

fig. 4.1.14 shared landscapes in addition to shared entranceways, the landscapes within neighbourhoods such as Knob Hill could begin to link together and funtion as a whole. Shown is the potential for two privately owned yards to link with a publicly owned street side lot to form a large storm retention pond or water storage cistern. The sharing of landscapes could also be applied to linking various landscapes into linear farms, or groupings of community vegetable gardens, or SPIN farming plots.

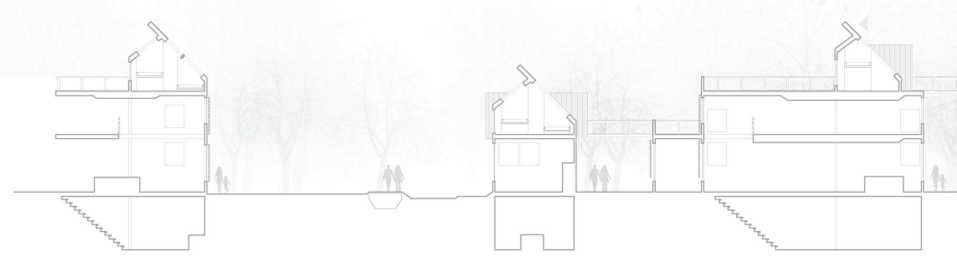




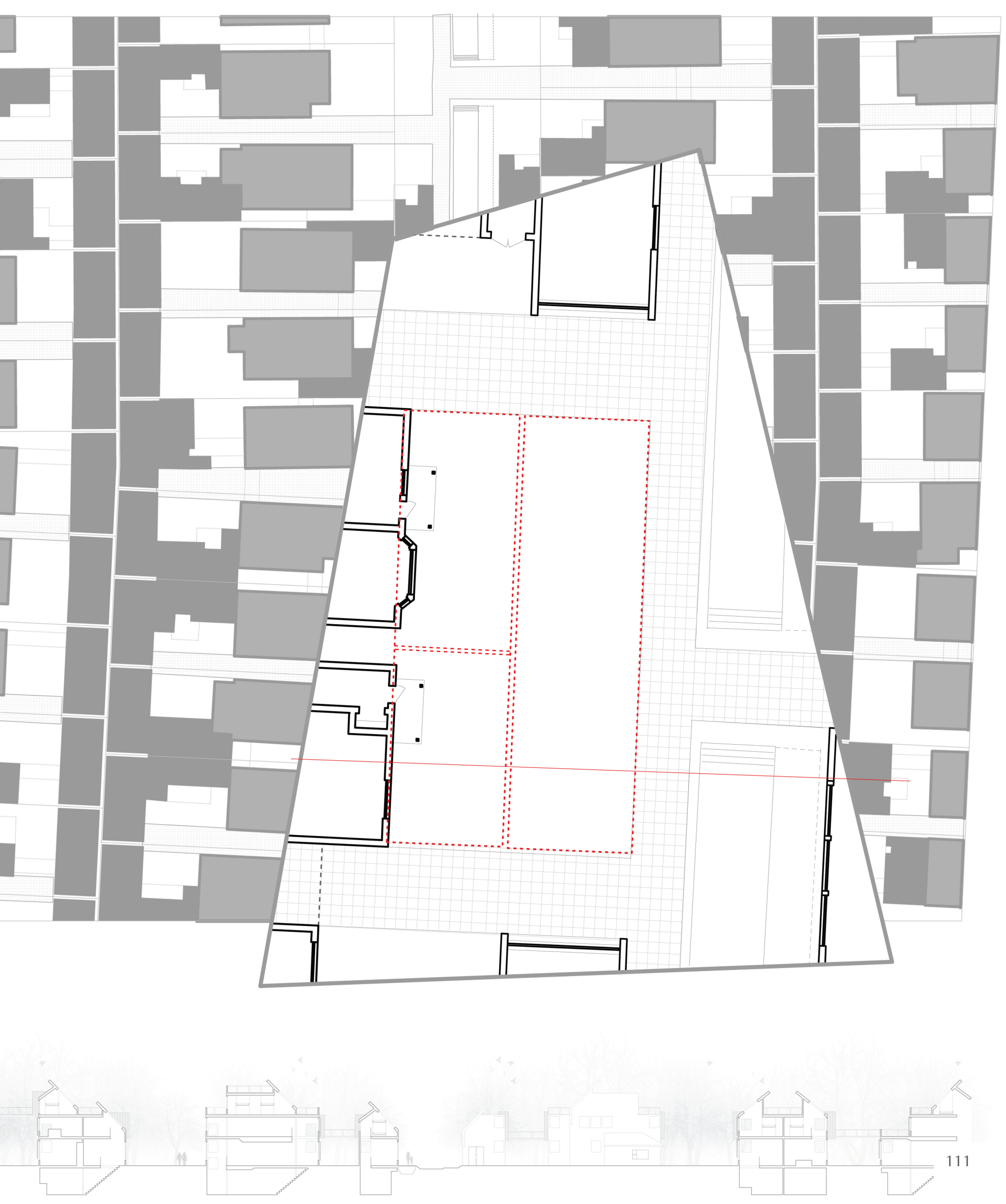


fig. 4.1.15 private outdoor space although one of the qualities of suburban Toronto is the abundance of privately owned greenspace, very little of it is experienced as private. As was discussed earlier, the contradictory nature of suburban space ensures that the privately owned yards of each house is experienced as a public boulevard. While such public boulevard is maintained through the use of the woonerf, private outdoor space is also created through the placement of new buildings. Shown is the creation of two previously non-existent private courtyards located within the front yards of the lots. Through the strategic creation of such private outdoor space, each home, addition, granny flat and streetside public building could have its own access to outdoor greenspace.

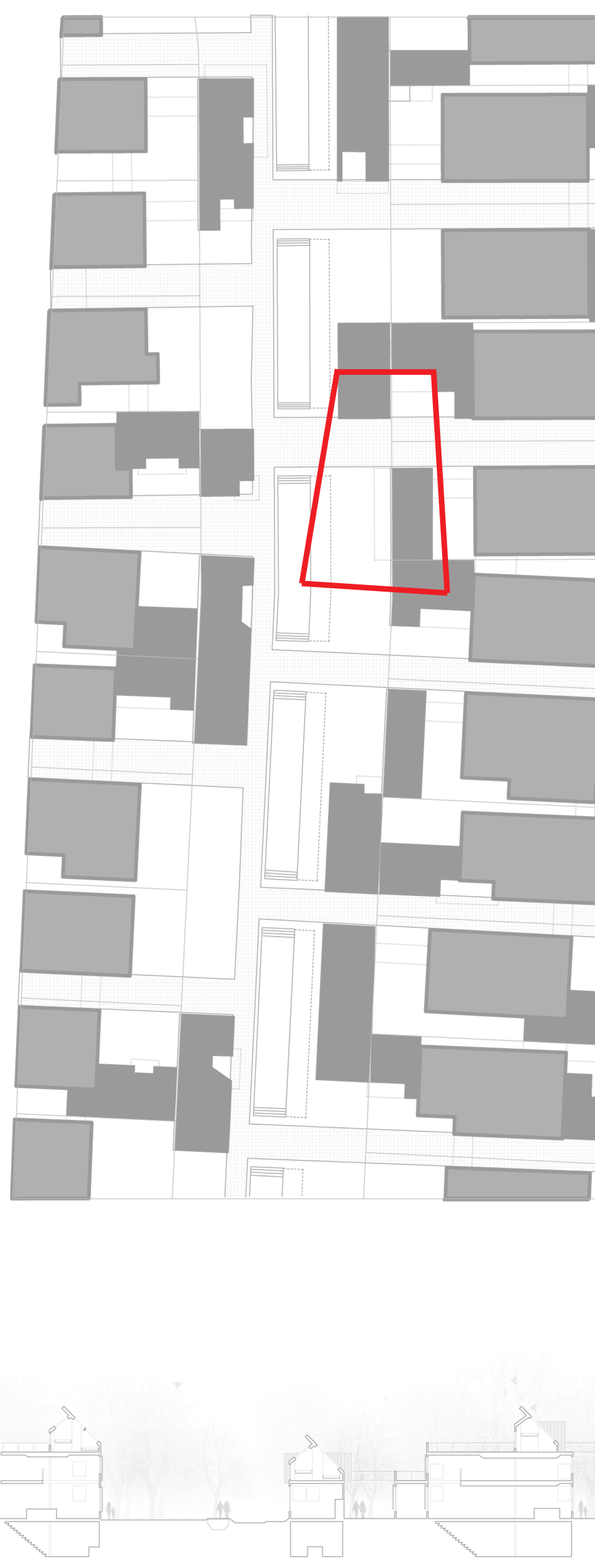



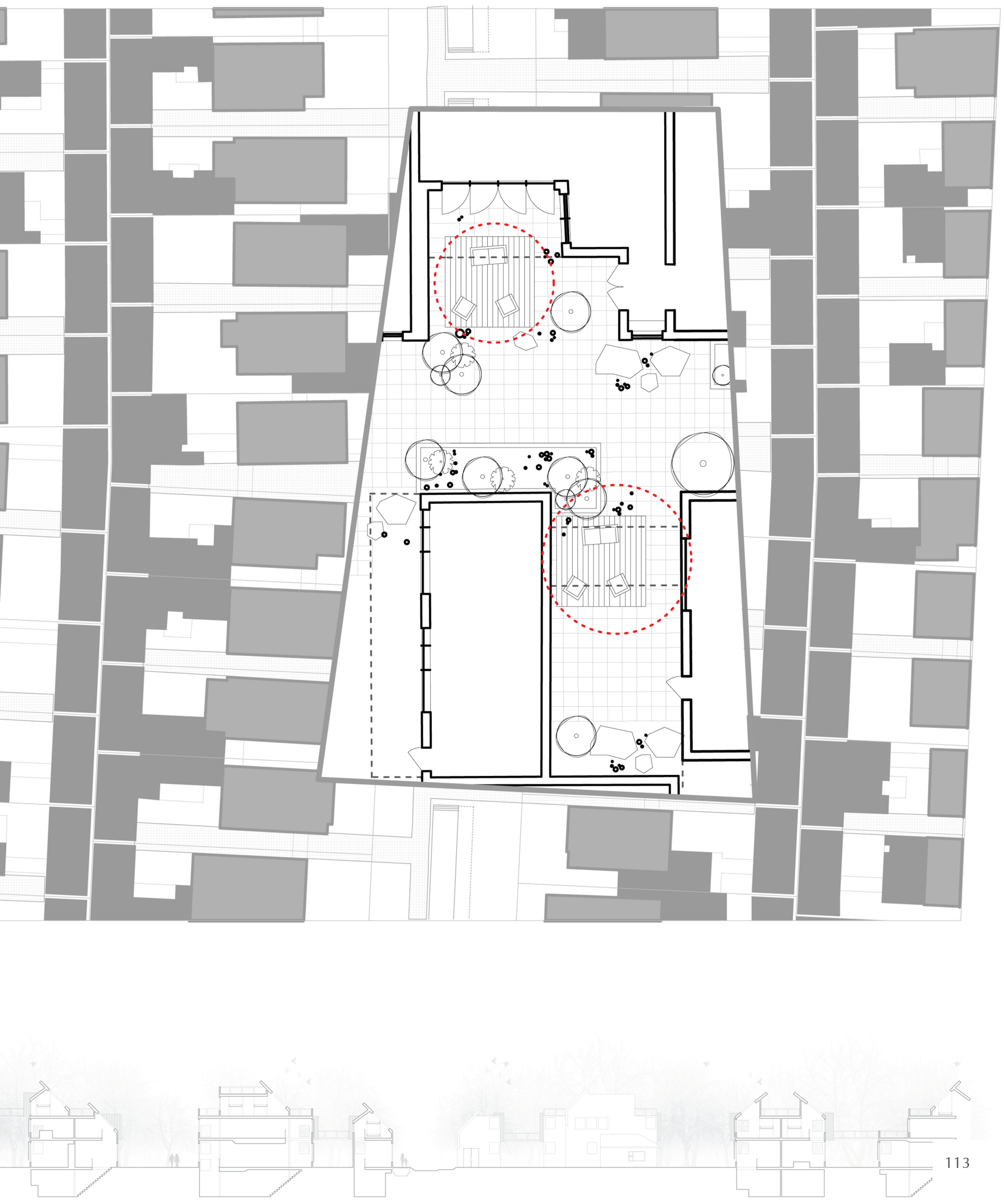
fig. 4.1.16 incremental changes in suburban Toronto the proposed redevelopment strategy is intended to be a flexible framework for renewal in suburban Toronto. By identifying both public and private areas for the creation of new buildings and the creation of productive landscapes, neighbourhoods such as Knob Hill will be free to spatially reinvent their built environment. This will likely occur over many years, as the neighbourhood and city incrementally responds to feedback loops caused by future vulnerabilities.

First steps in the redevelopment strategy would likely involve a redefining of the street into a woonerf, followed by the accumulation of new units, second storeys, and additional living space - conventional changes to the neighbourhood. As resources become scarcer, oil becomes more expensive, food becomes harder to find, and water is valued as a rare resource, these neighbourhoods will likely begin to respond through the creation of productive landscapes and new buildings with productive programs.

The series shown demonstrates the incremental accumulation of new landscapes and buildings within a block of Knob Hill, indicating gradual changes to the neighbourhood as time passes. It should be stated that the various streets within Knob Hill would develop differently based on their location within the neighbourhood. Areas within proximity of the city's arterials would likely focus on the creation of new units, offices, and retail based outbuildings, whereas areas further from arterials would likely focus on productive landscape strategies. This is explored further in the following section a broader context.

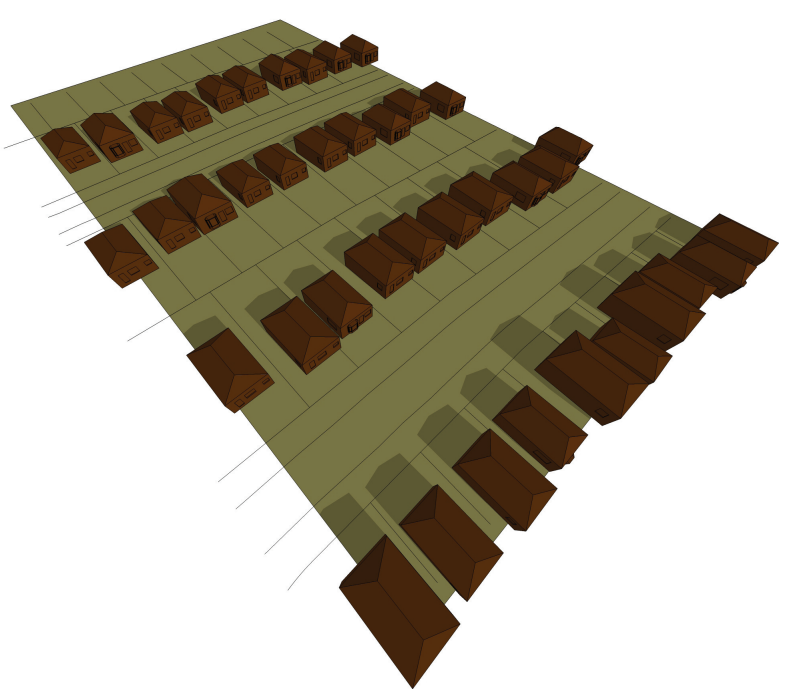



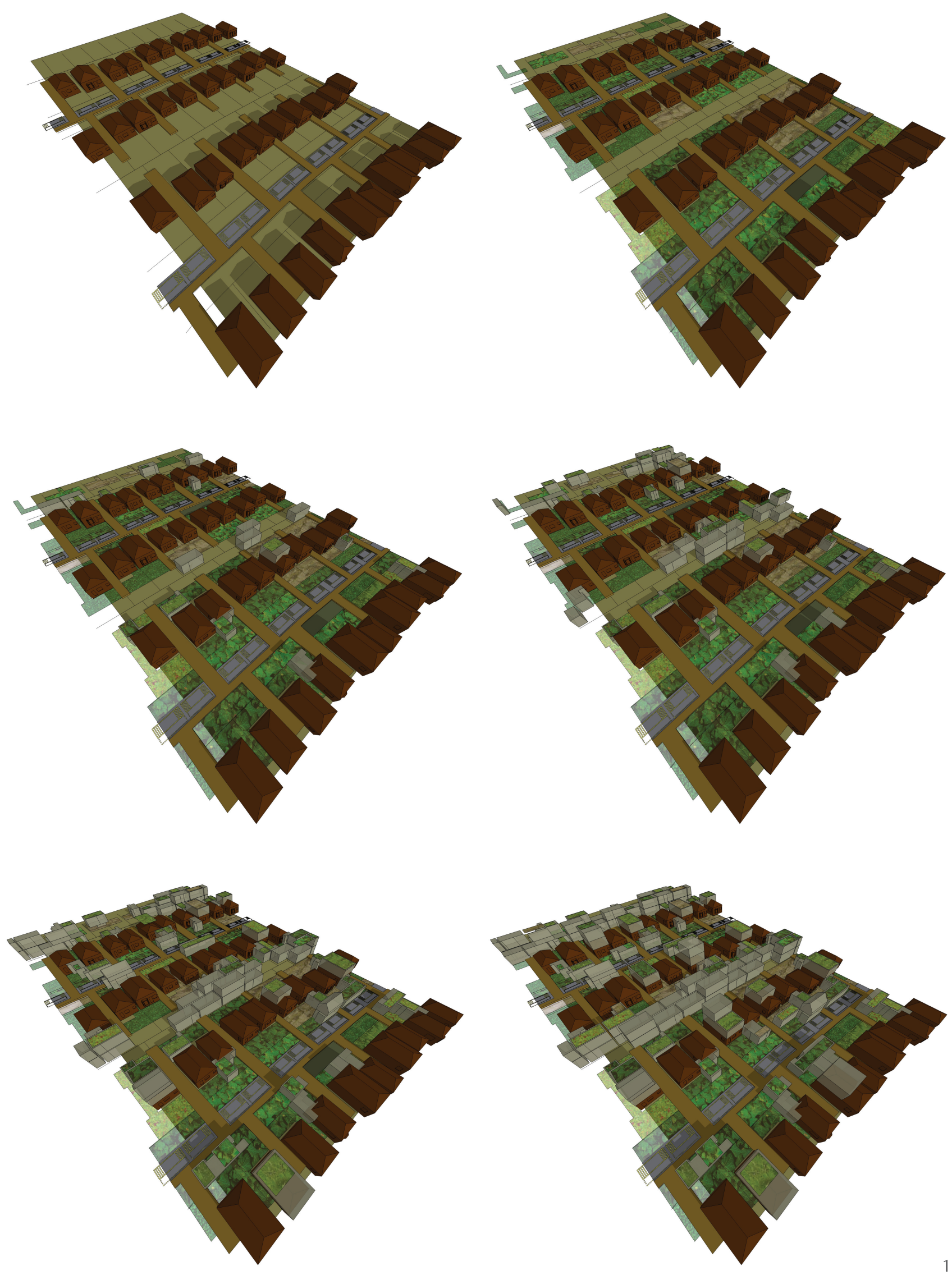


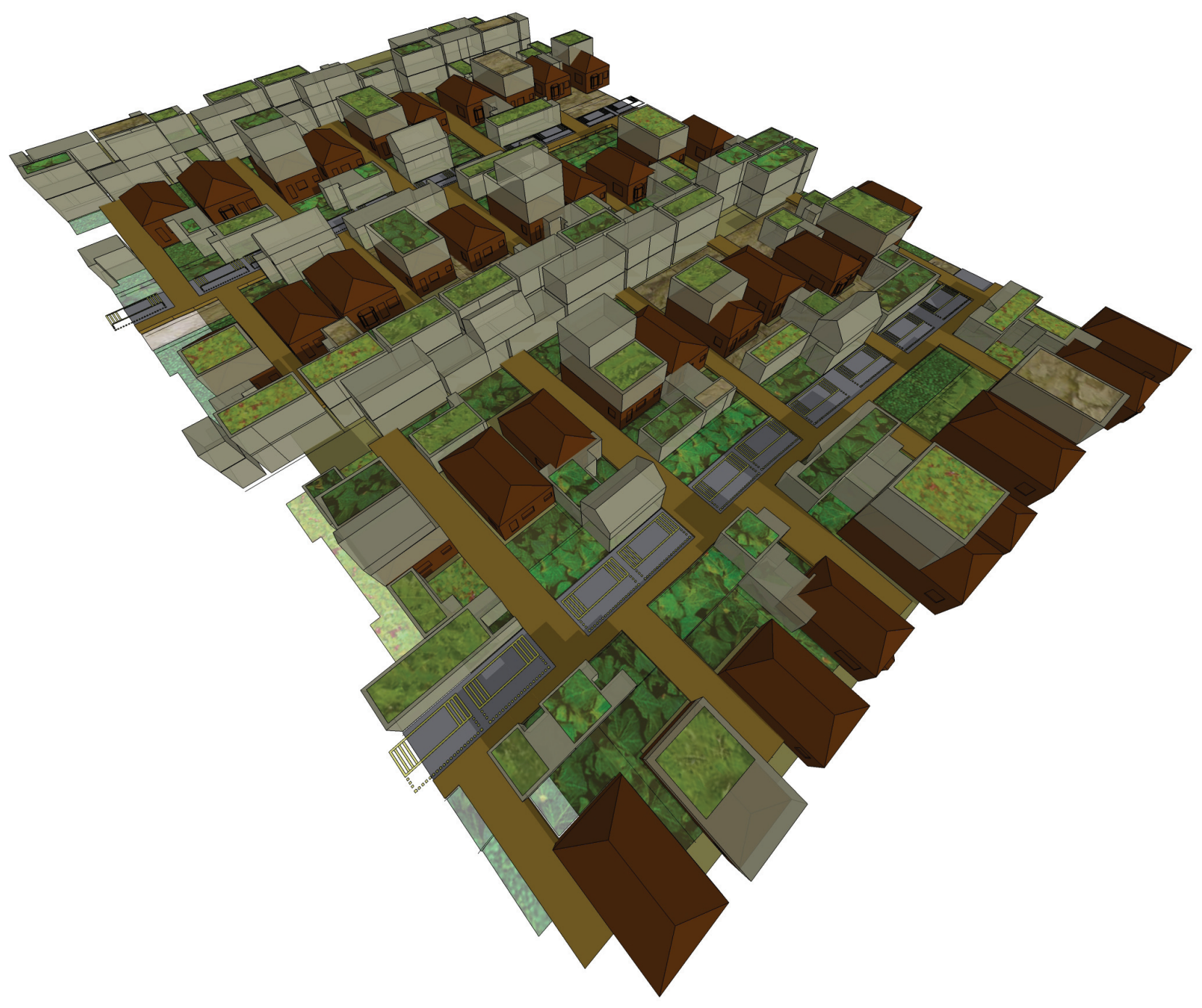


4.2 a broader context this section of the design exploration begins to link the framework for redefining the suburbs established in the previous section with the strategies explored in the section productivity matrix. The 5 themes presented in the matrix exercise (water, ecology, food, energy, material) were further developed into 5 typologies for suburban Toronto: suburban Toronto as wetland marsh; suburban Toronto as urban forest; suburban Toronto as bread basket; suburban Toronto as solar collector; and suburban Toronto as shoe cobbler. Although an overlapping of the 5 typologies within a neighbourhood is highly likely, the 5 typologies presented are meant to demonstrate how portions of a suburban neighbourhood, such as Knob Hill,might begin to develop within a particular theme depending on the residents desires and their location within the neighbourhood. As is demonstrated, a wetland marsh approach would ideally work with the ravine systems throughout Toronto, connecting the strategies employed in a wetland marsh streetscape to greater systems that reach out beyond the city's boundaries. A broader context begins by creating the narrative for each of the 5 typologies through the use of rendered perspectives, and goes on to locate those narratives within the Knob Hill neighbourhood and the city as a whole. 


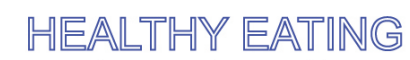

Community Health

Income Generation
WALIRING

Pedestrian Friendly

Walking Networks

Scenic Transportation

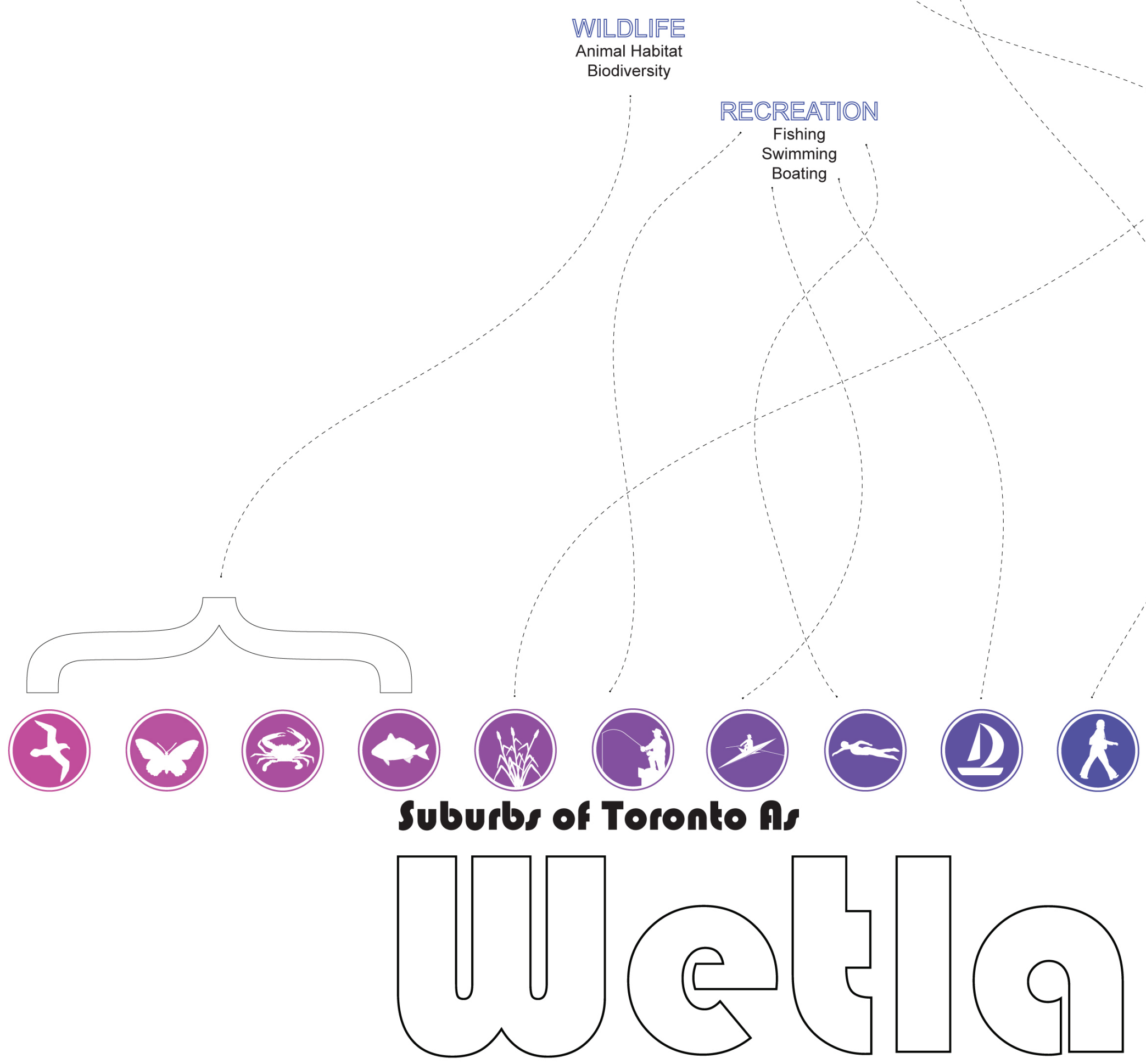




\section{previous}

fig. 4.2.1 elements of the wetland marsh

fig. 4.2.2 wetland marsh narrative the narrative created for the wetland marsh typology focuses on demonstrating the incorporation of water filtration strategies, wildlife habitat, aquaponics facilities, and means of water storage such as underground water cisterns. There is also the potential for recreational activities such as playing, fishing, bi-

cycling and walking.
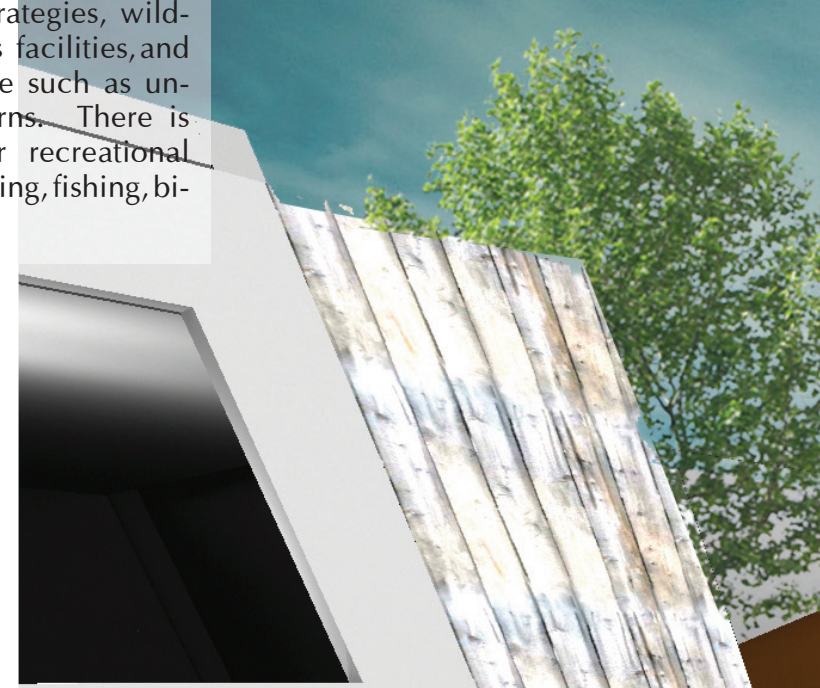


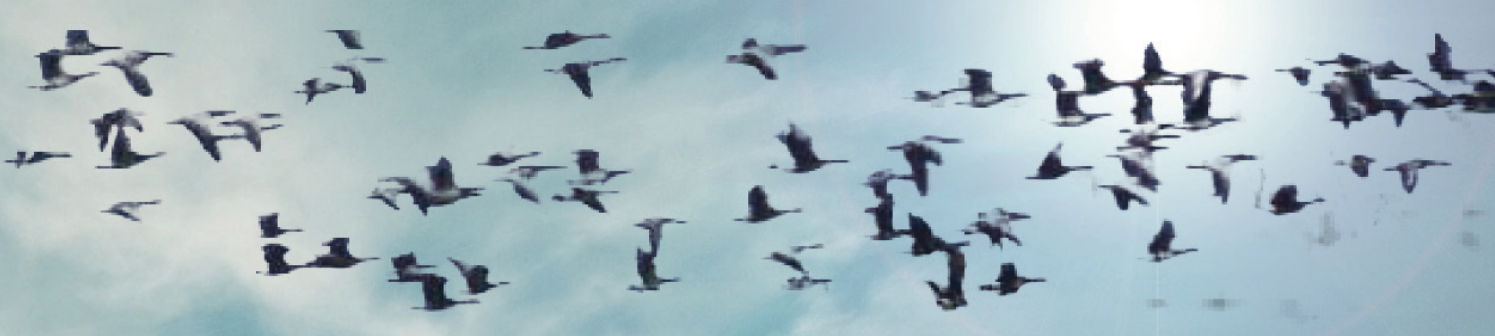

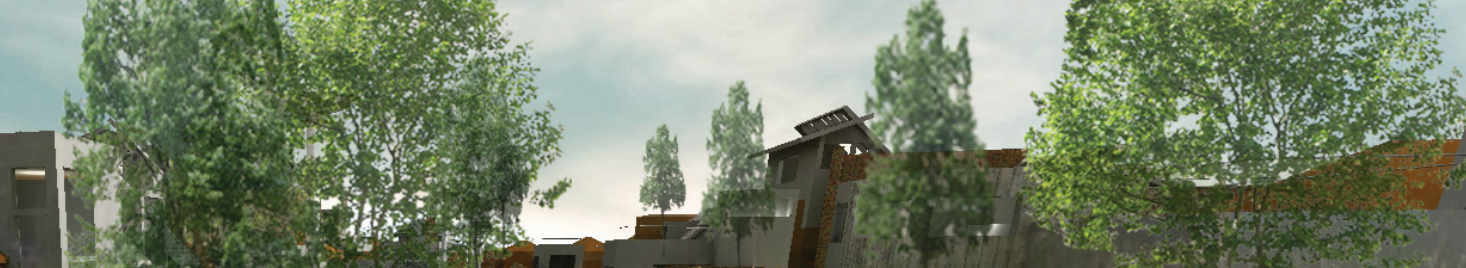

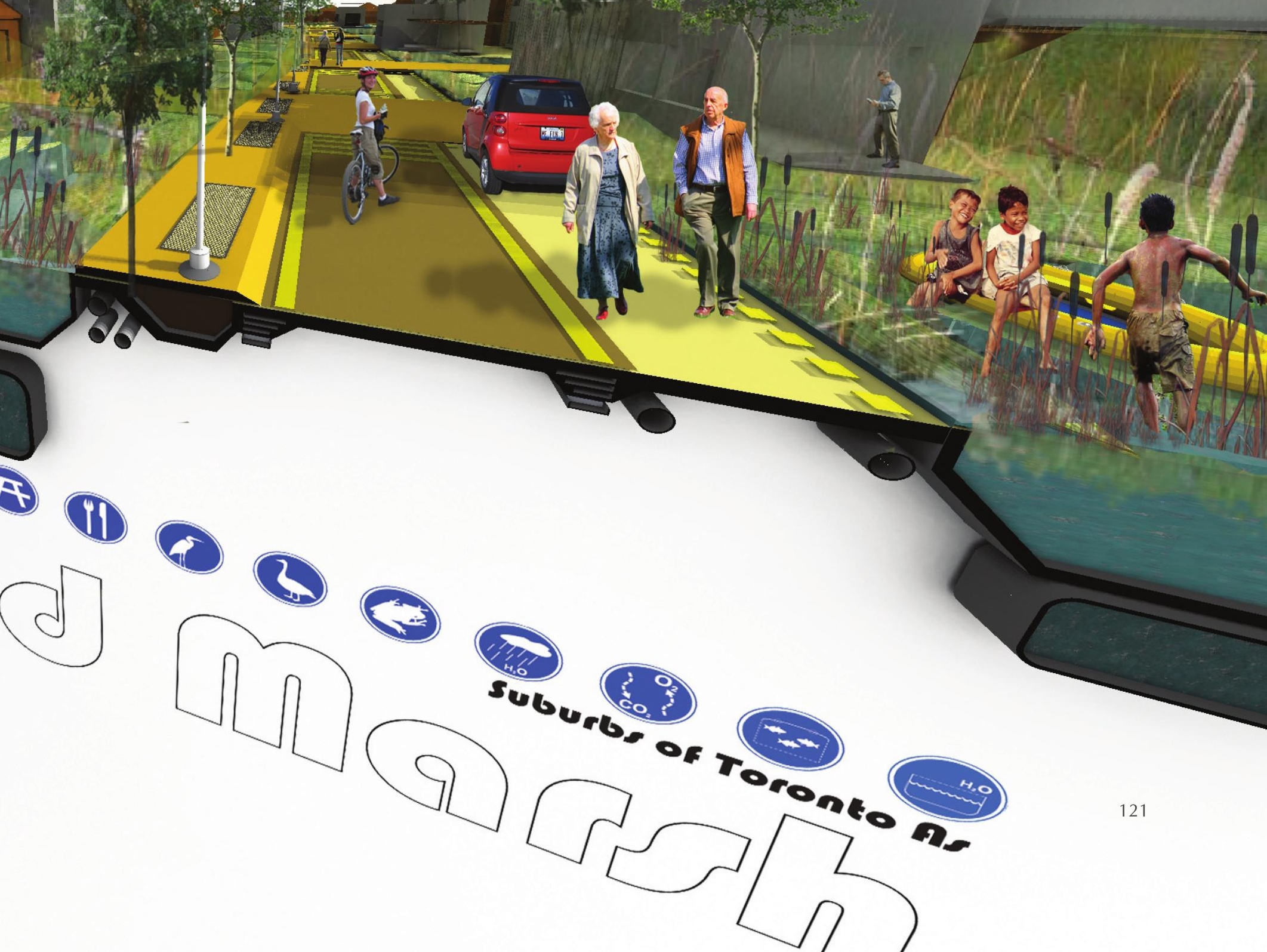




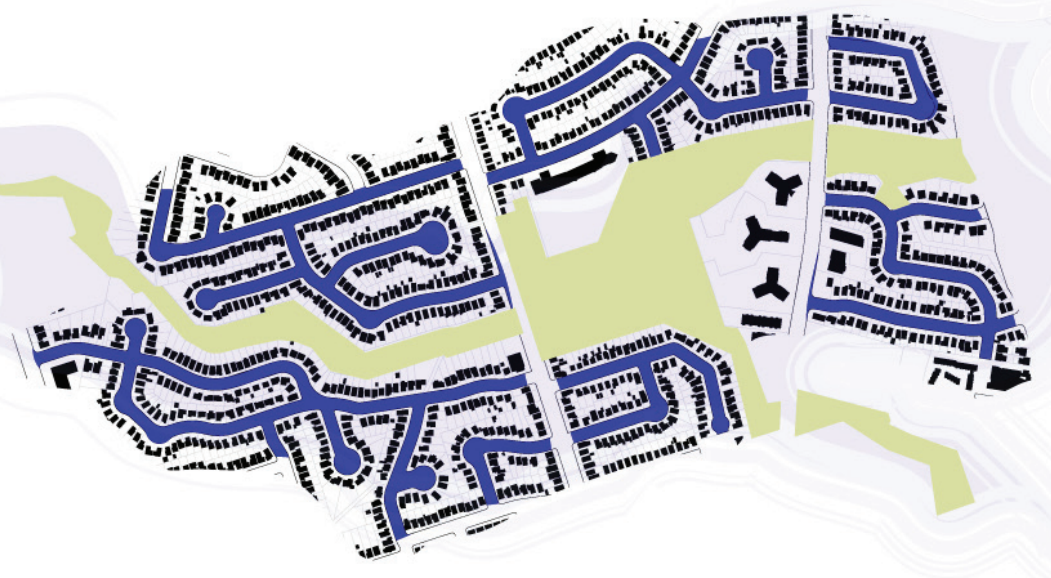

fig. 4.2.3 wetland marsh located in Knob Hill it is proposed that wetland marsh typologies (locations focusing on water remediation, wildlife habitat, and water storage, etc.) will be located in close proximity to the ravine systems of the neighbourhood. In this way, the remediation strategies occuring in these typologies could act as extentions of the ecological features already occuring in the neighbourhood.

\section{opposite}

fig. 4.2.4 Toronto ravine system shown is the extensive network of ravines and waterways located throughout Toronto and the GTA. Any wetland marsh approach would need to connect to these larger systems and the watersheds, natural vegetation, wildlife habitats, and mi-

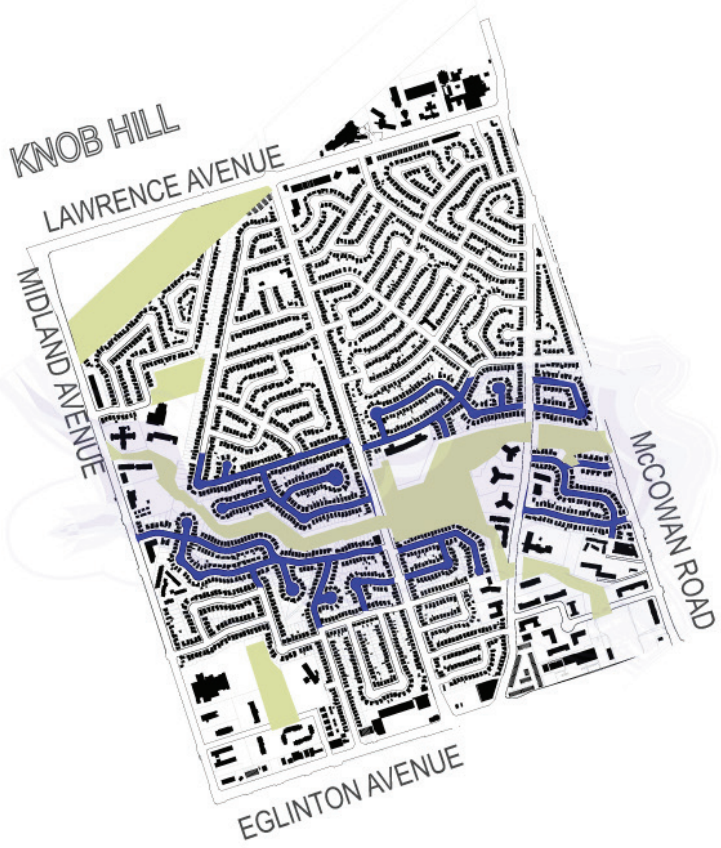
gratory paths that they involve. 


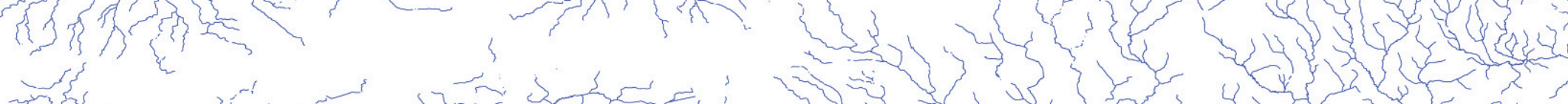

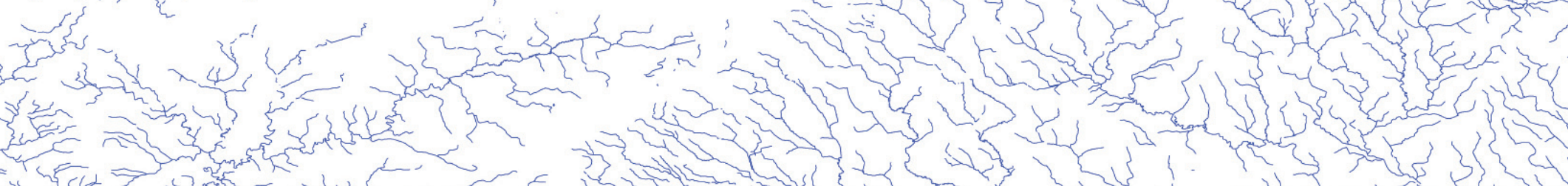

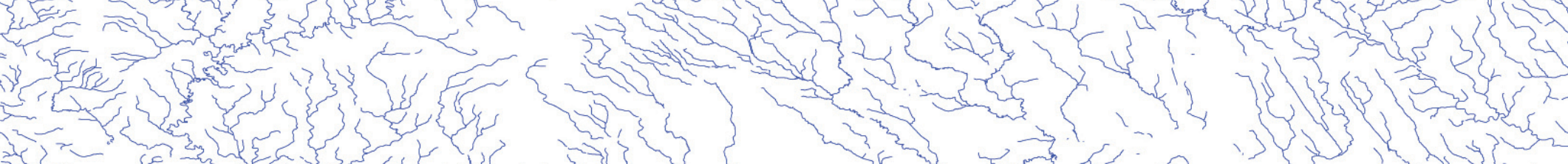

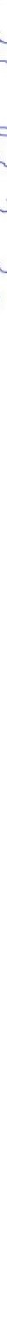

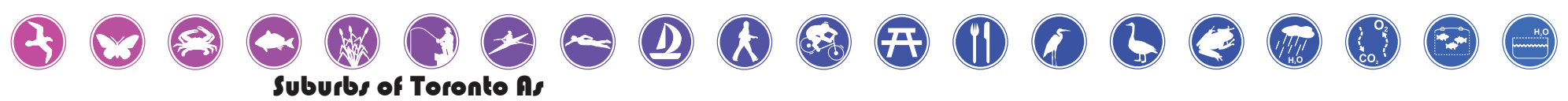

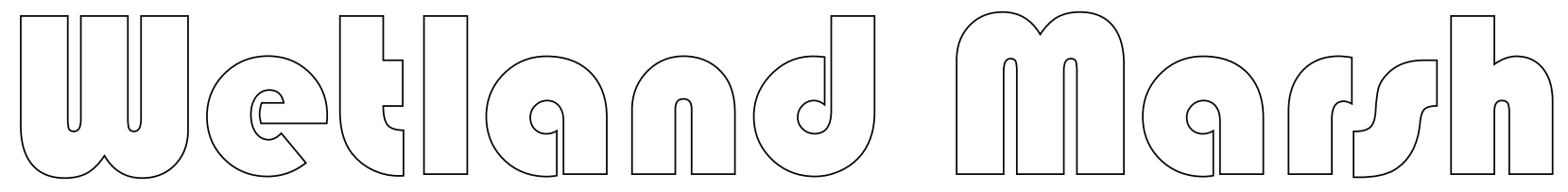


PHOT(OSN][ESIS

Carbon Sequestration

Air Remediation
F(ORESTR區S

Urban Tree Stand

Wildlife Habitat

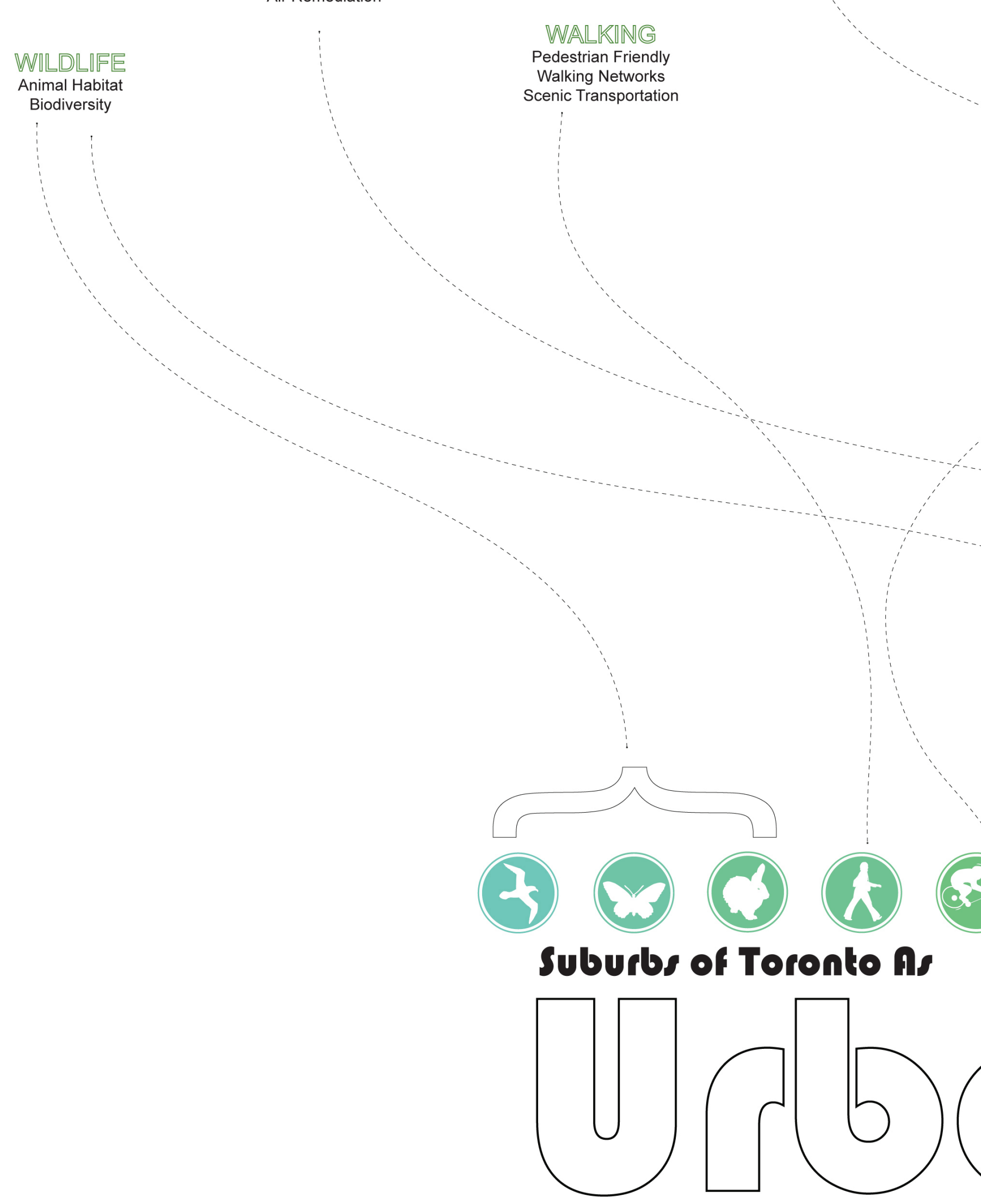




\section{previous}

fig. 4.2.5 elements of the urban forest

fig. 4.2.6 urban forest narra-

tive the narrative created for the urban forest typology focuses on demonstrating the incorporation of woodland settings, wildlife habitat, and wood fuel storage. There is also the potential for recreational activities such as camping, camp fires, bicycling, walking, and wood chopping.
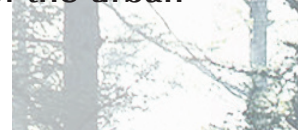

$\sin 20$
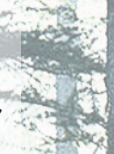
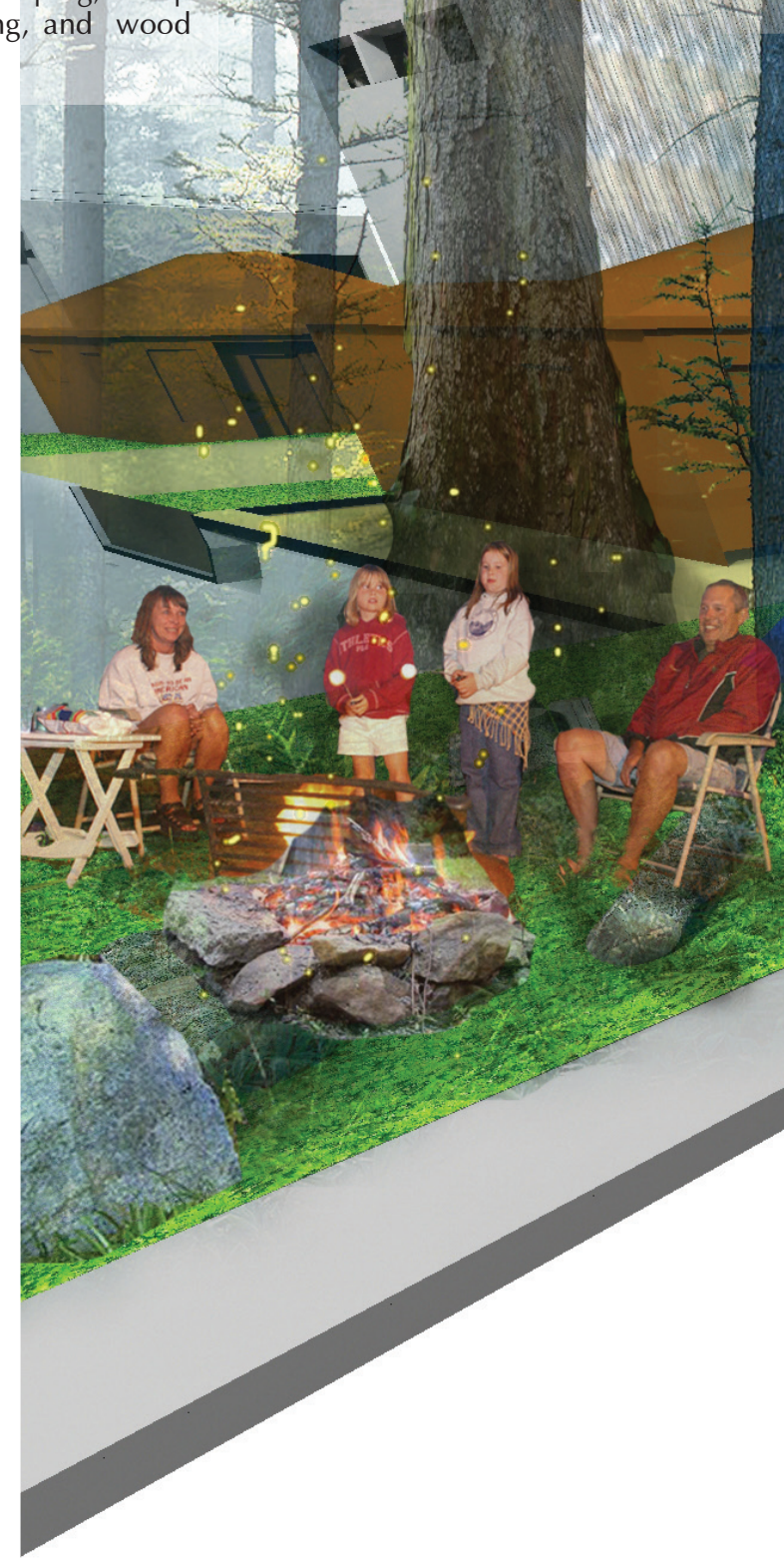

A
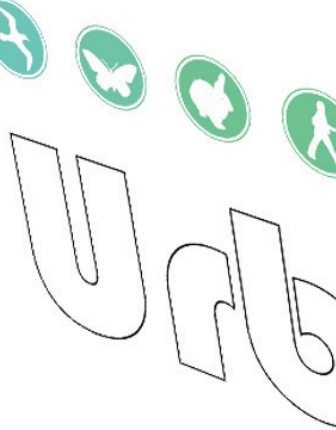


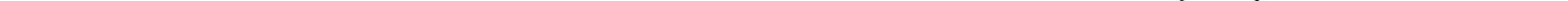


fig. 4.2.7 urban forest located in Knob Hill it is proposed that urban forest typologies (locations focusing on woodland environments, wildlife habitat, air remediation, etc.) will be located in close proximity to the existing parks and greenspace of the neighbourhood. In this way, the ecological features of these typologies could act as extentions of the existing greenspace of the city.

\section{opposite}

fig. 4.2.8 Toronto greenspace shown is the extensive network of parks and greenspace located throughout Toronto and the GTA. Any urban forest approach would need to connect to these larger systems and the natural vegetation, wildlife habitat and migratory paths that they involve.

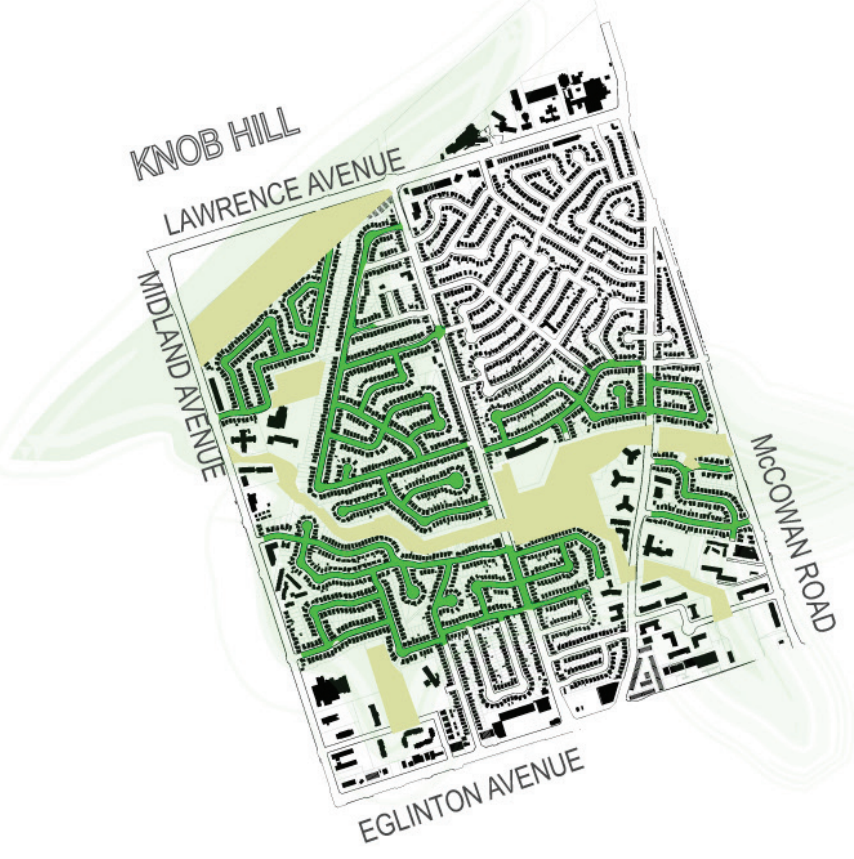


B) $\|$ C C

Pedestrian Friendly

Bicycle Networks Scenic Transportation

\section{URBAN}

AGRICULTURE Local Food System
FRESH FOOD Local Food System Community Health Income Generation
PUCNICS

Common Eating Areas

Social Space
Local Food System Community Agriculture Income Generation

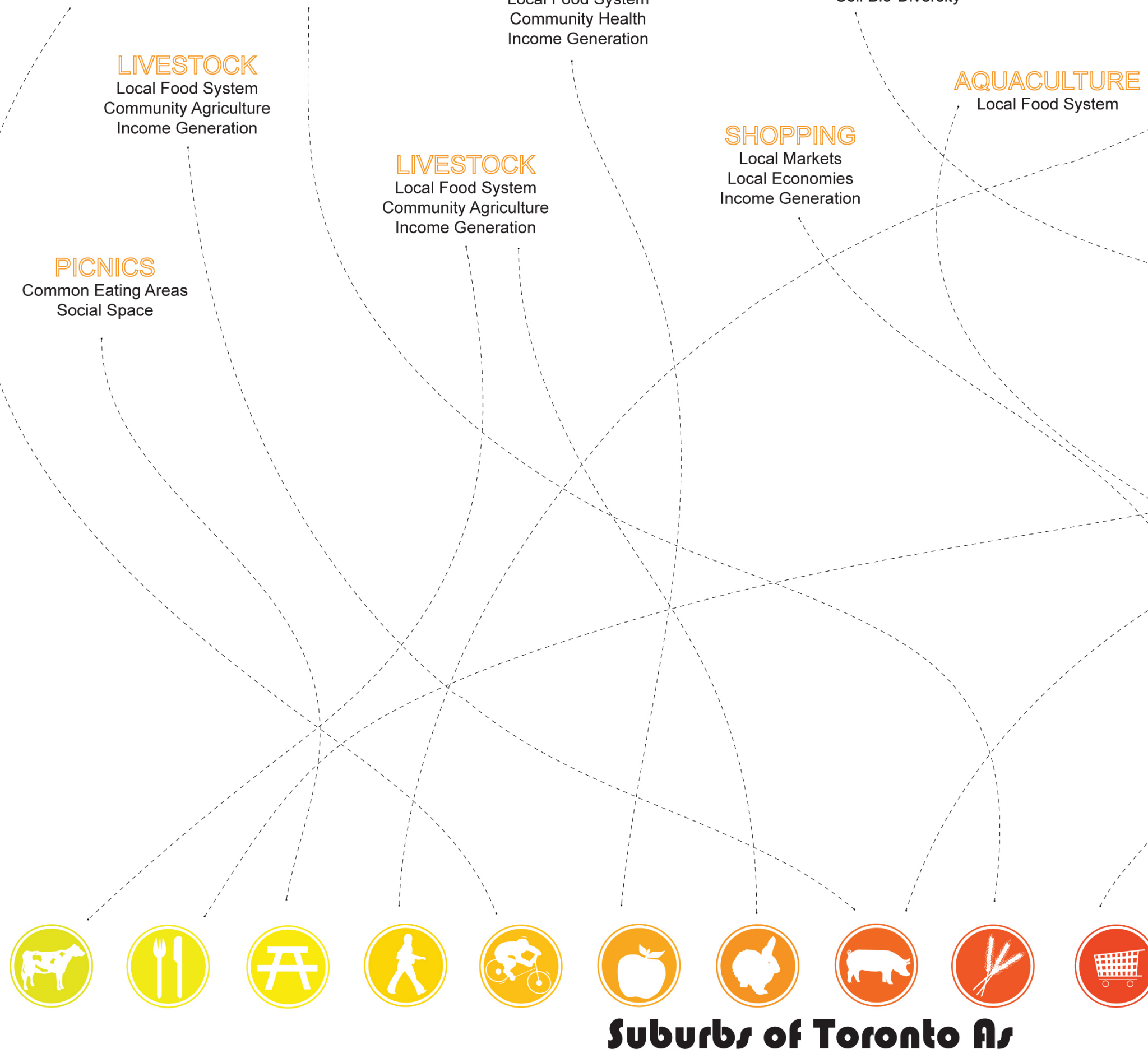

\section{แIESTOCK Local Food System Community Agriculture} Income Generation
HEAM『UY SOML

Soil Remediation Organic Fertilization Soil Bio-Diversity

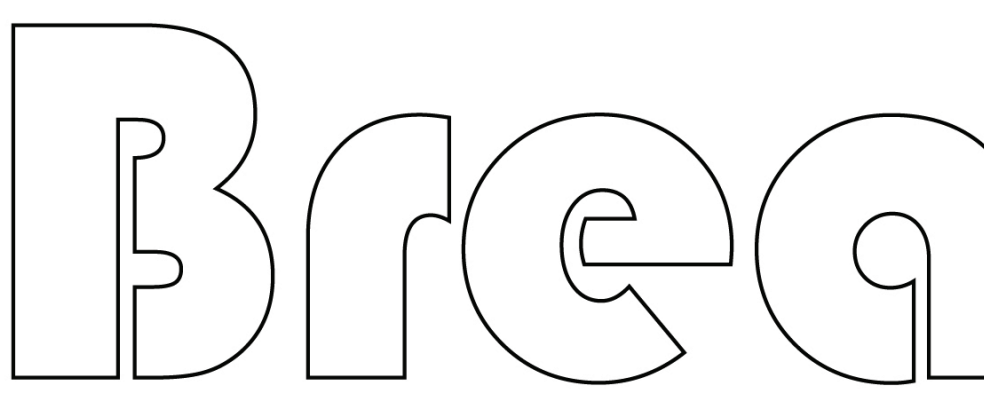




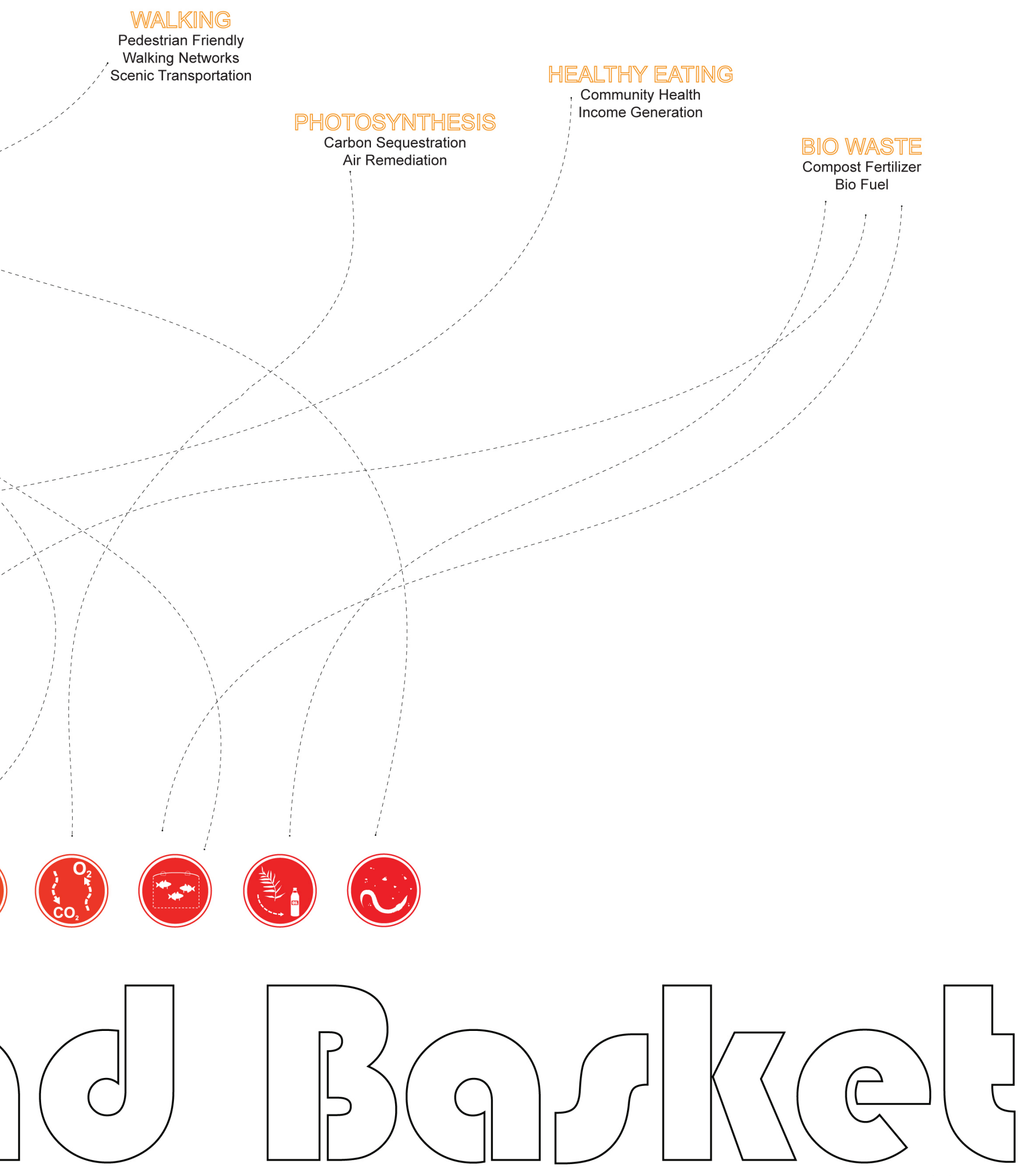




\section{previous}

fig. 4.2.9 elements of the bread basket

fig. 4.2.10 bread basket narrative the narrative created for the bread basket typology focuses on demonstrating the incorporation of food production, including bee keeping, linear farms, greenhouses, livestock and cold storage facilities. There is also the potential for recreational activities such as playing, walking, bicycling, and eating.
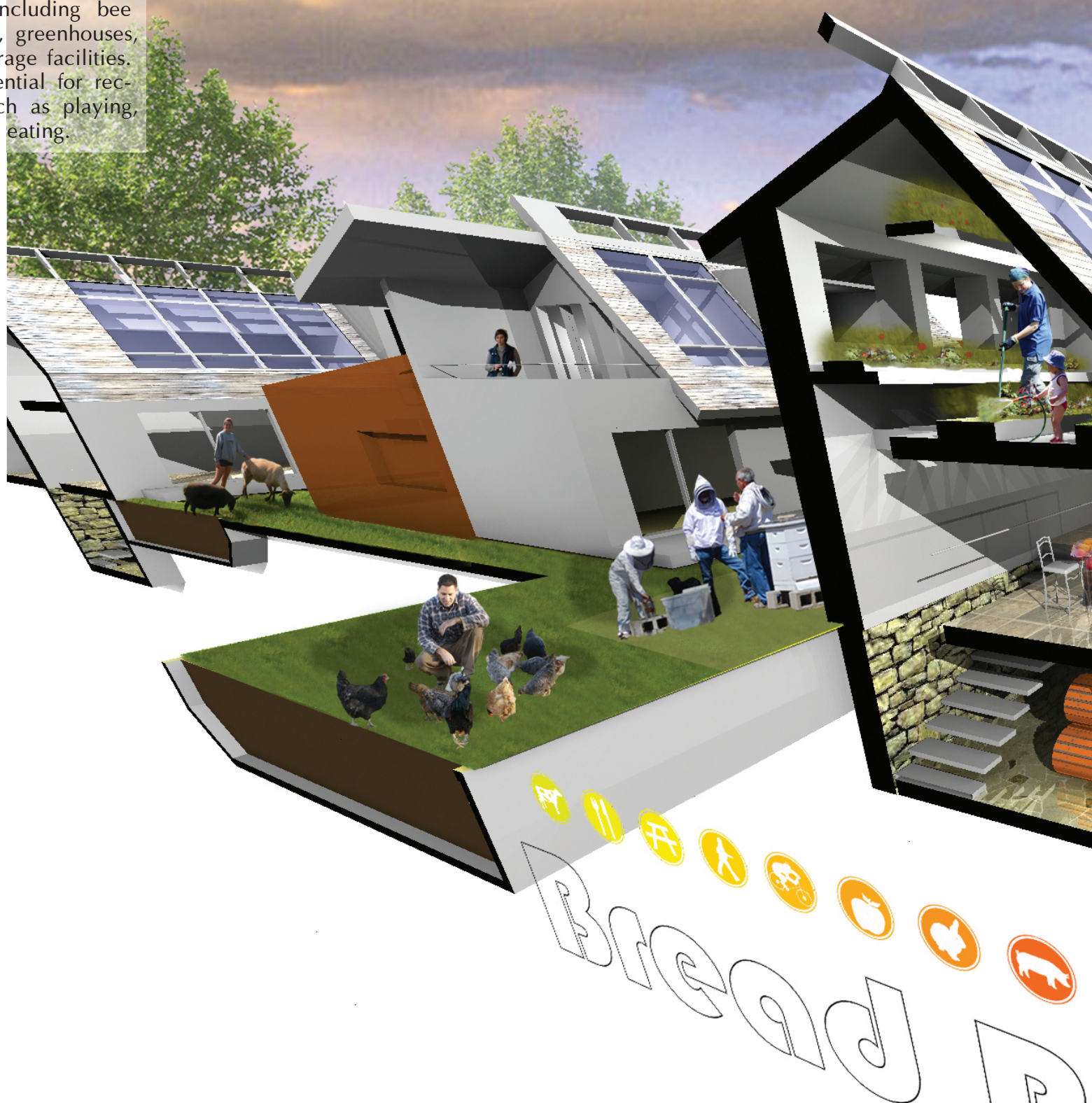

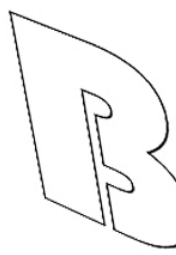


fig. 4.2.11 bread basket located in Knob Hill it is proposed that bread basket typologies (locations focusing on food production) will be located throughout the neighbourhood.There is strong potential for the incorporation of food production into various locations throughout the neigbourhood. What is critical for the bread basket approach is linking the food production to sales locations - market nodes that provide healthy food from within existing food deserts. It is proposed that the abundance of schools found throughout Toronto would be used for this purpose. In this way, food production occuring throughout the neighbourhood could be linked with sales locations within walking distance of residents.

\section{opposite}

fig. 4.2.12 Toronto wards and schools shown is the ward and school locations of Toronto and the GTA. Any bread basket approach would need to network between each ward and could use the array of schools within Toronto as possible locations selling healthy food.

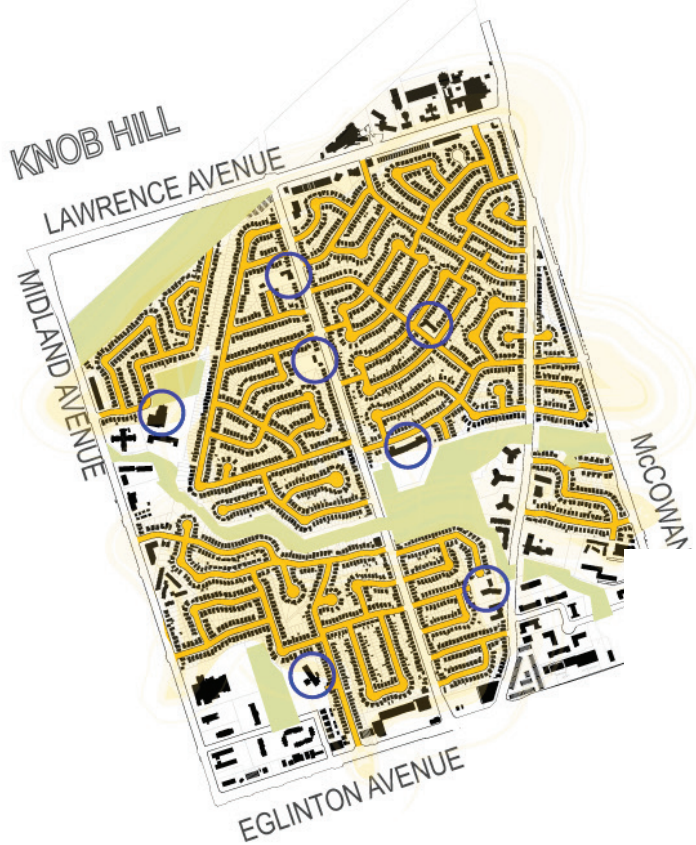




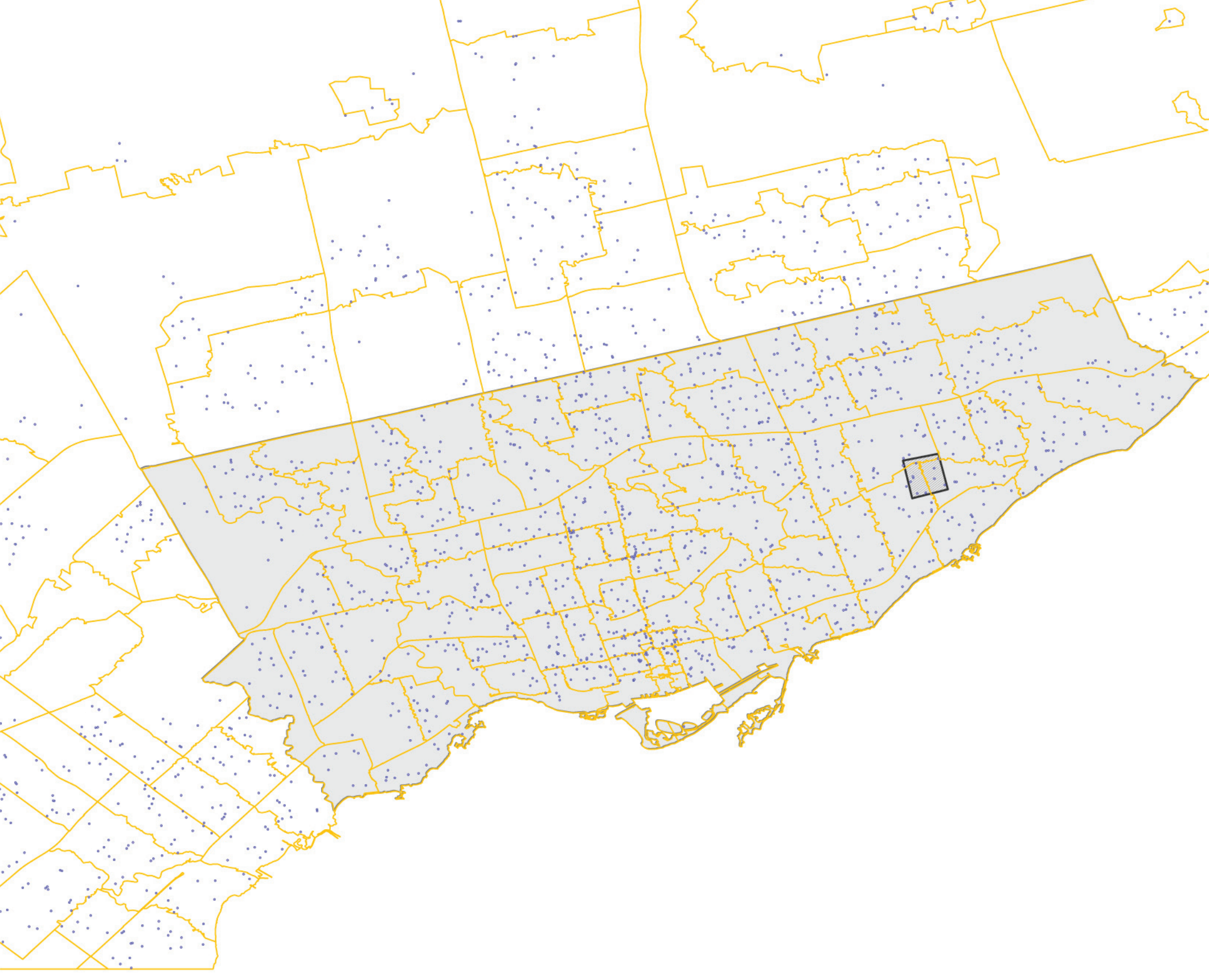




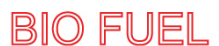

Energy Production

Income Generation

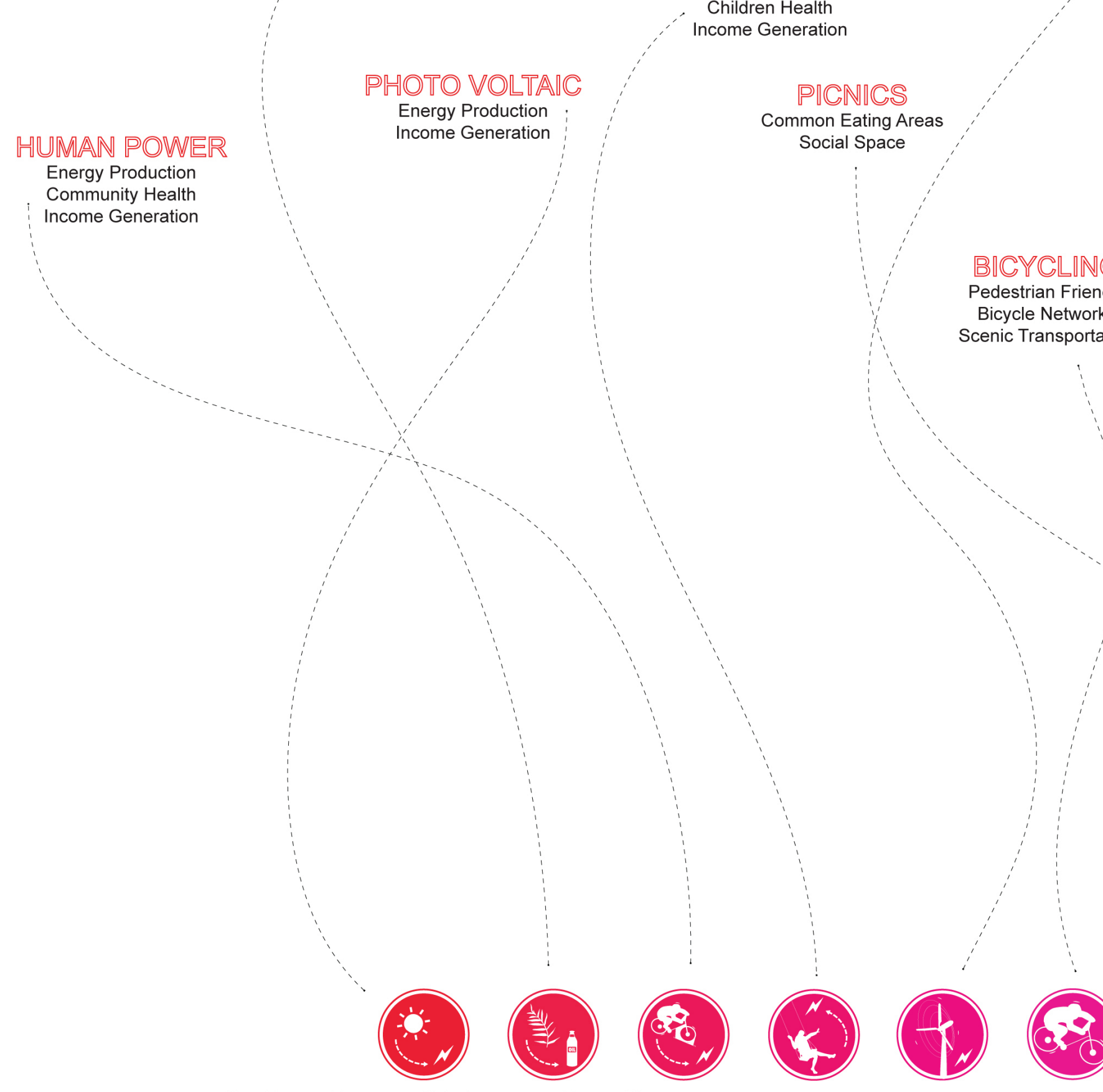

KID POW ER

Energy Production

Children Health

Income Generation

\section{Suburbs of Toronto in}
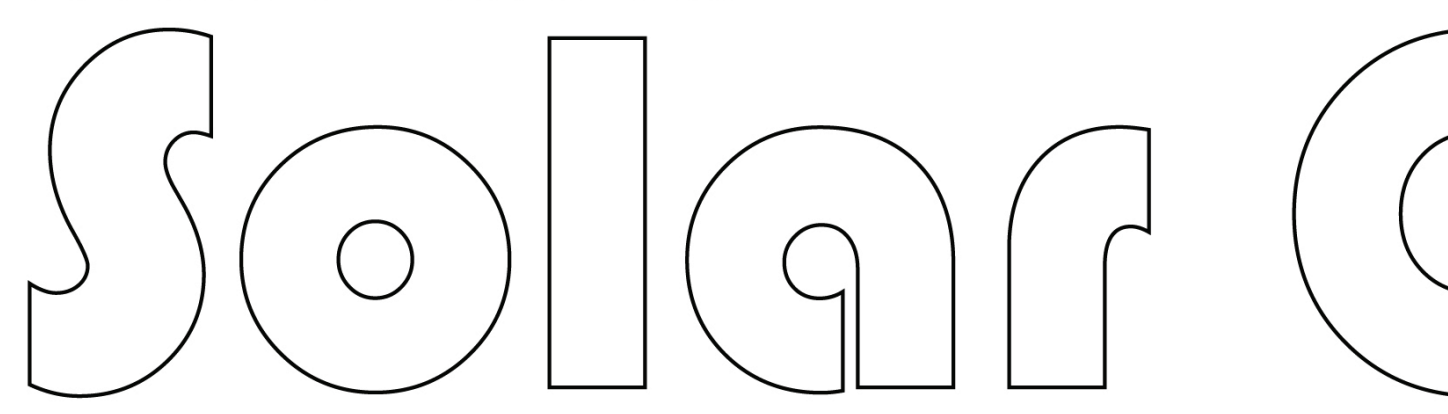


\section{previous}

fig. 4.2.13 elements of the solar collector

fig. 4.2.14 solar collector narrative the narrative created for the solar collector typology focuses on demonstrating the incorporation of energy production including wind power, solar power, geothermal energy, CHP units, and bio-fuel cultivation. There is also the potential for energy creating recreational activities such as workout rooms, bicycles, and jungle gyms which produce energy.

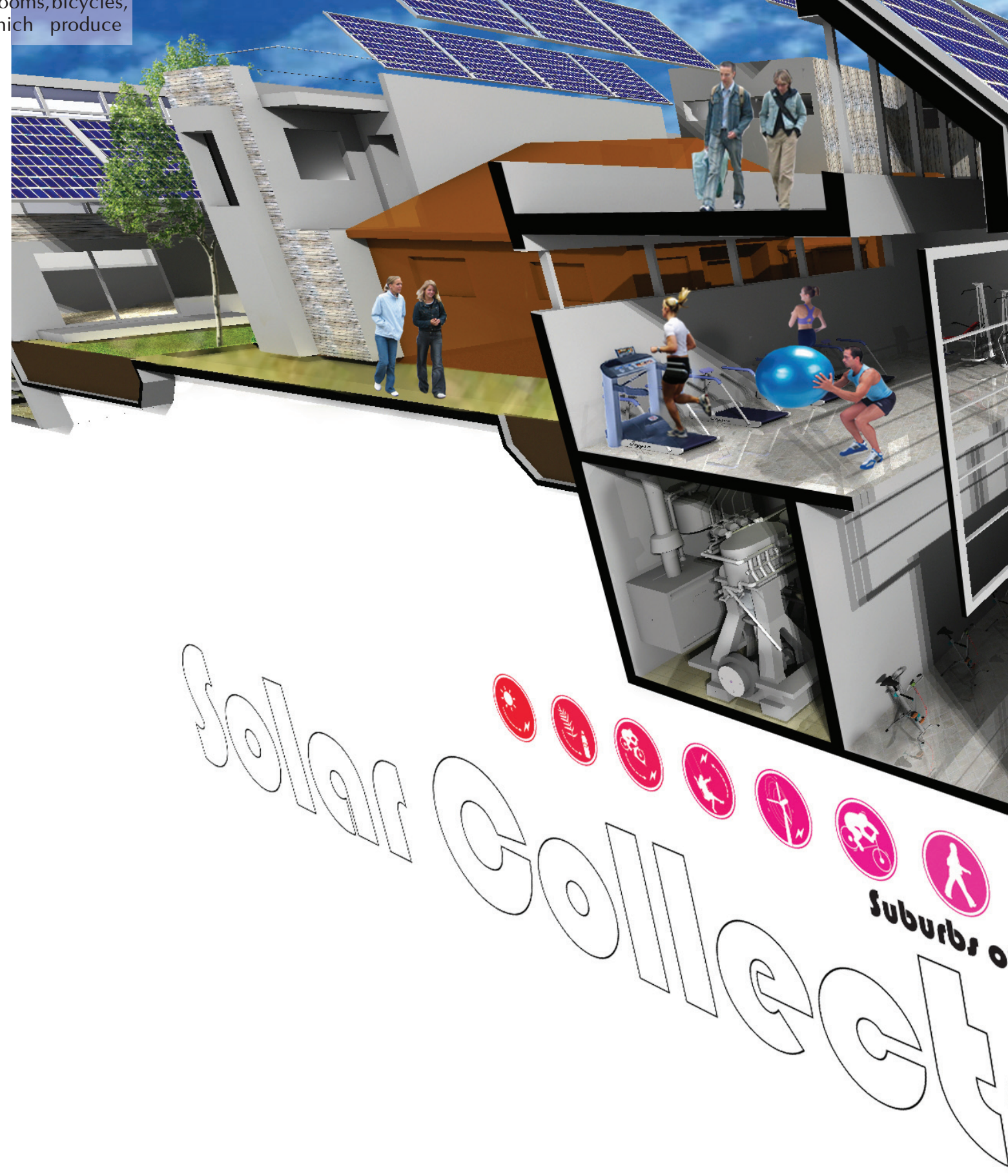




\section{(x) \\ $\int_{-16}^{6}=$}
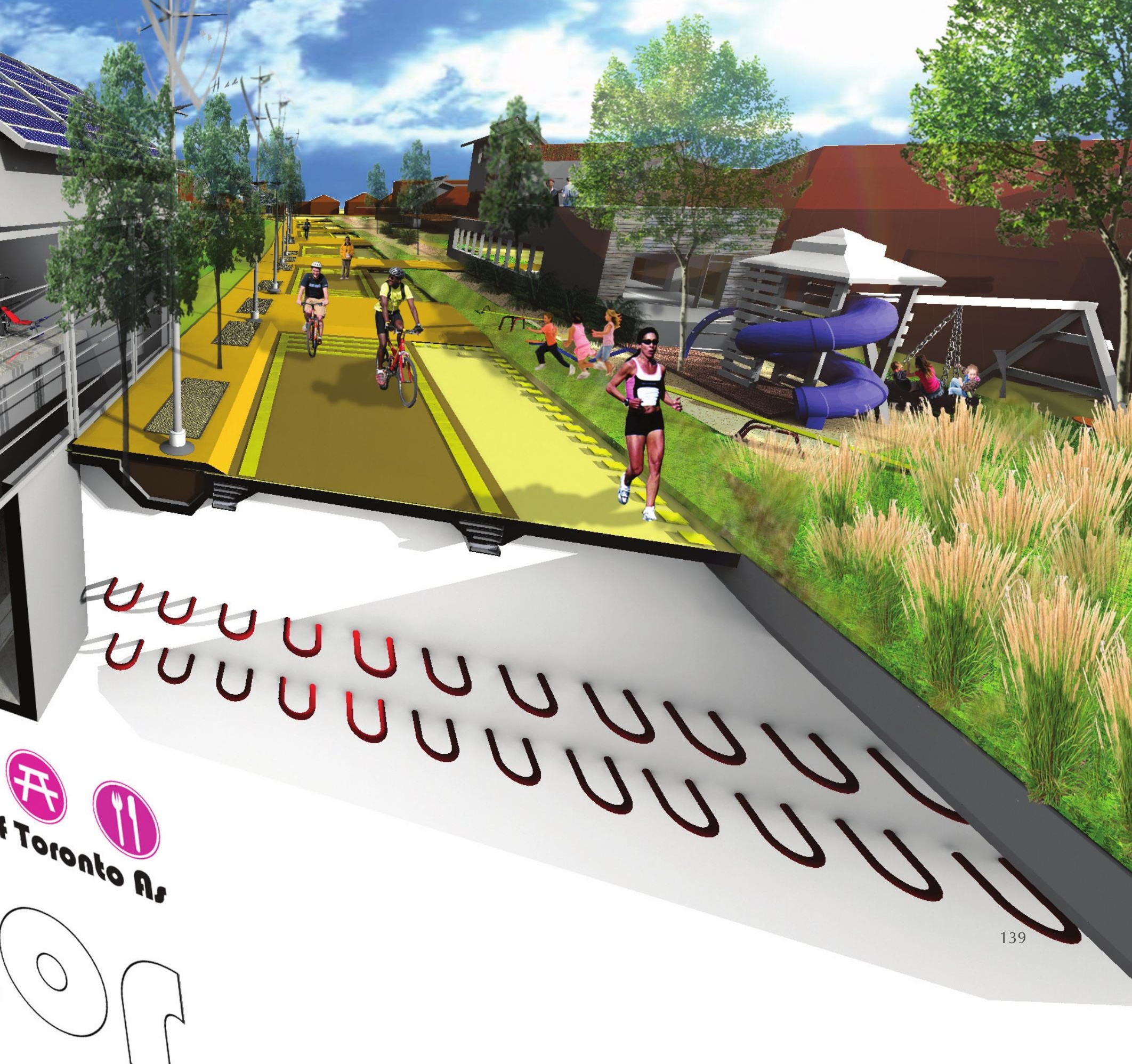
fig. 4.2.15 solar collector located in Knob Hill it is proposed that solar collector typologies (locations focusing on energy production) will be located throughout the neighbourhood. Energy producing strategies such as solar panels and solar hot water would need to occur at the core of the neighbourhood away from forested areas and areas within the shade of taller buildings. Whereas, energy producing strategies such as biofuel cultivation and CHP units would be better suited in forested and vegetation areas. In this way, various forms of energy production are suitable throughout the neighbourhood.

\section{opposite}

fig. 4.2.16 Toronto hydro corridors shown is the extensive network of powerlines, pipelines and hydro corridors traversing across Toronto and the GTA. Any solar collector approach would need to connect to these larger systems and the energy distribution systems that they involve.

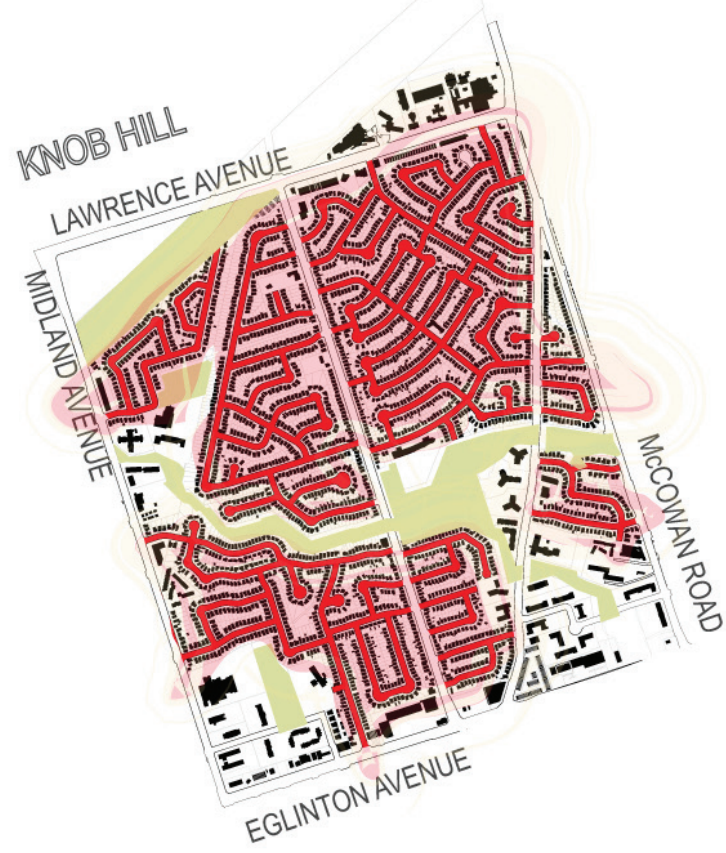




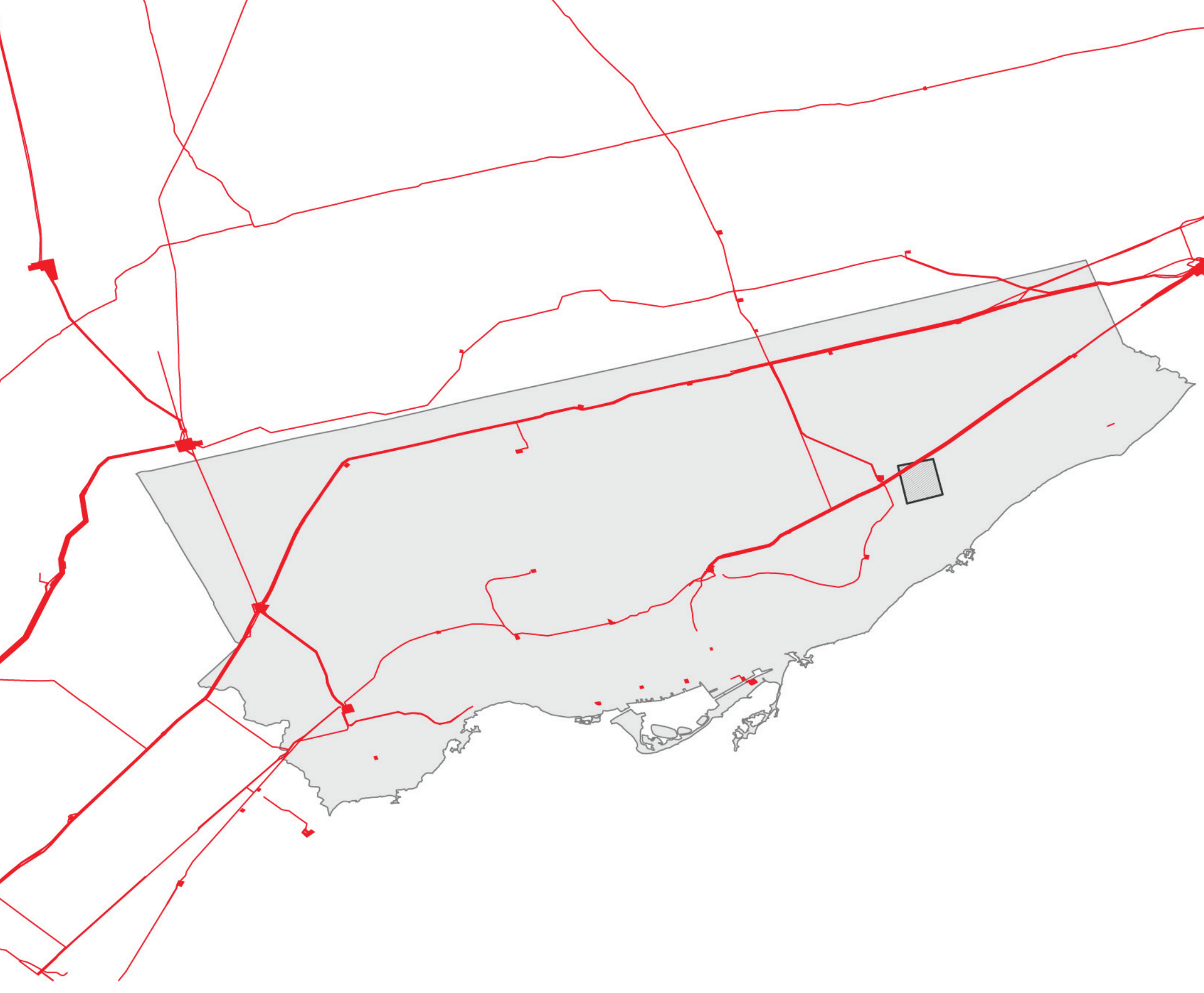


SHOPPING Local Markets Local Economies Income Generation

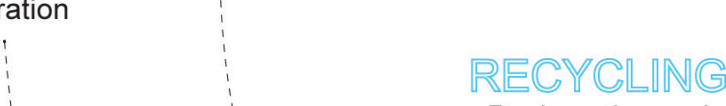

Reclamation and

Reuse of Materials

Income Generation

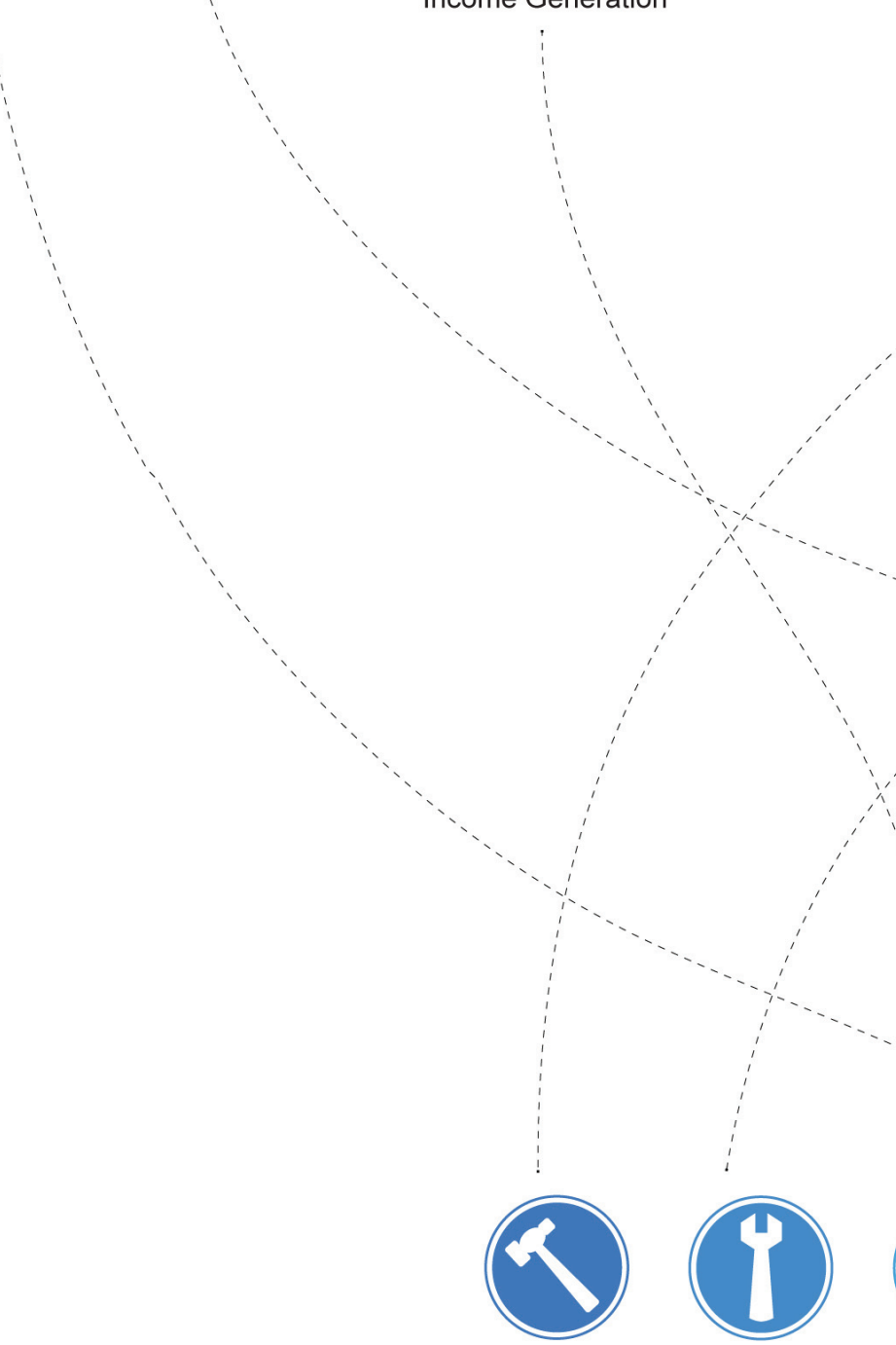

suburbs of Toronto ns
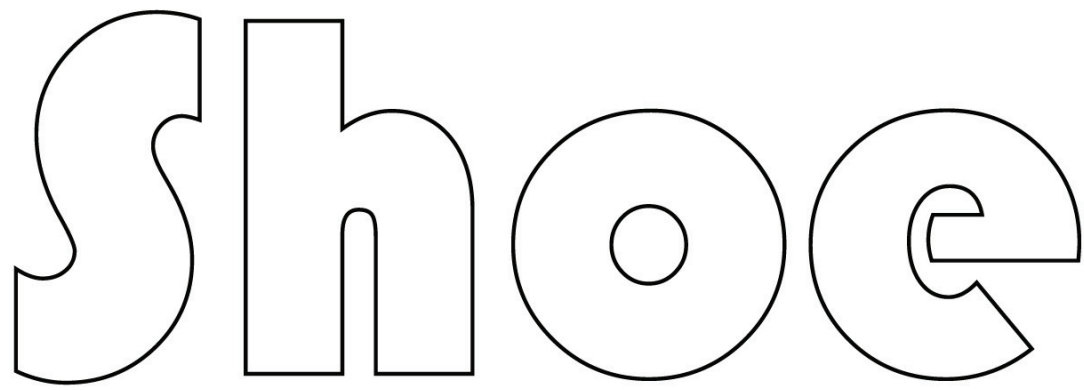

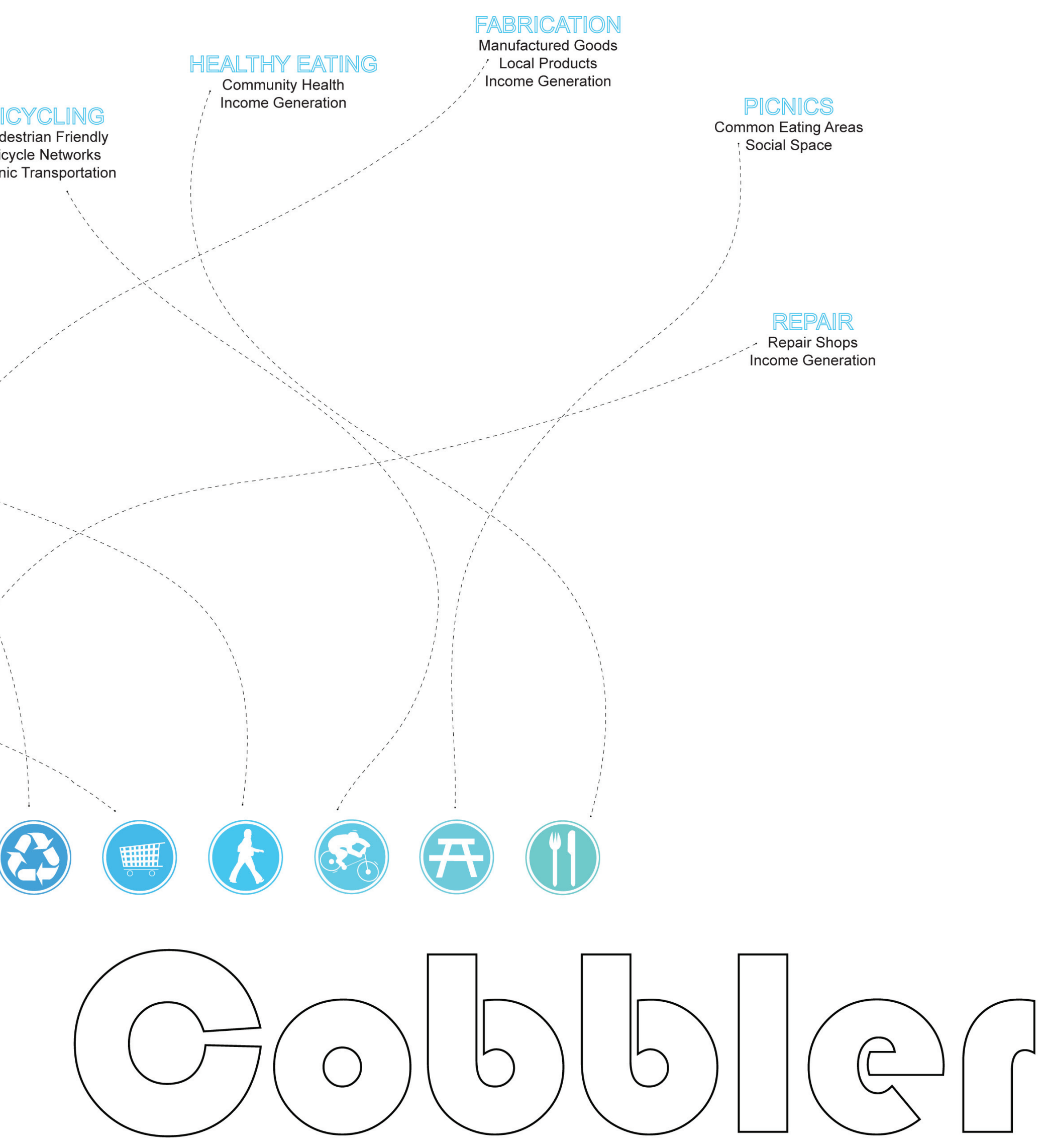


\section{previous}

fig. 4.2.17 elements of the shoe cobbler

fig. 4.2.18 shoe cobbler narrative the narrative created for the shoe cobbler typology focuses on demonstrating the incorporation of retail activities, repair shops, manufacturing facilities, and storage of reclaimed materials. There is also the potential for recreational activities such as shopping, busking, walking and bicycling.

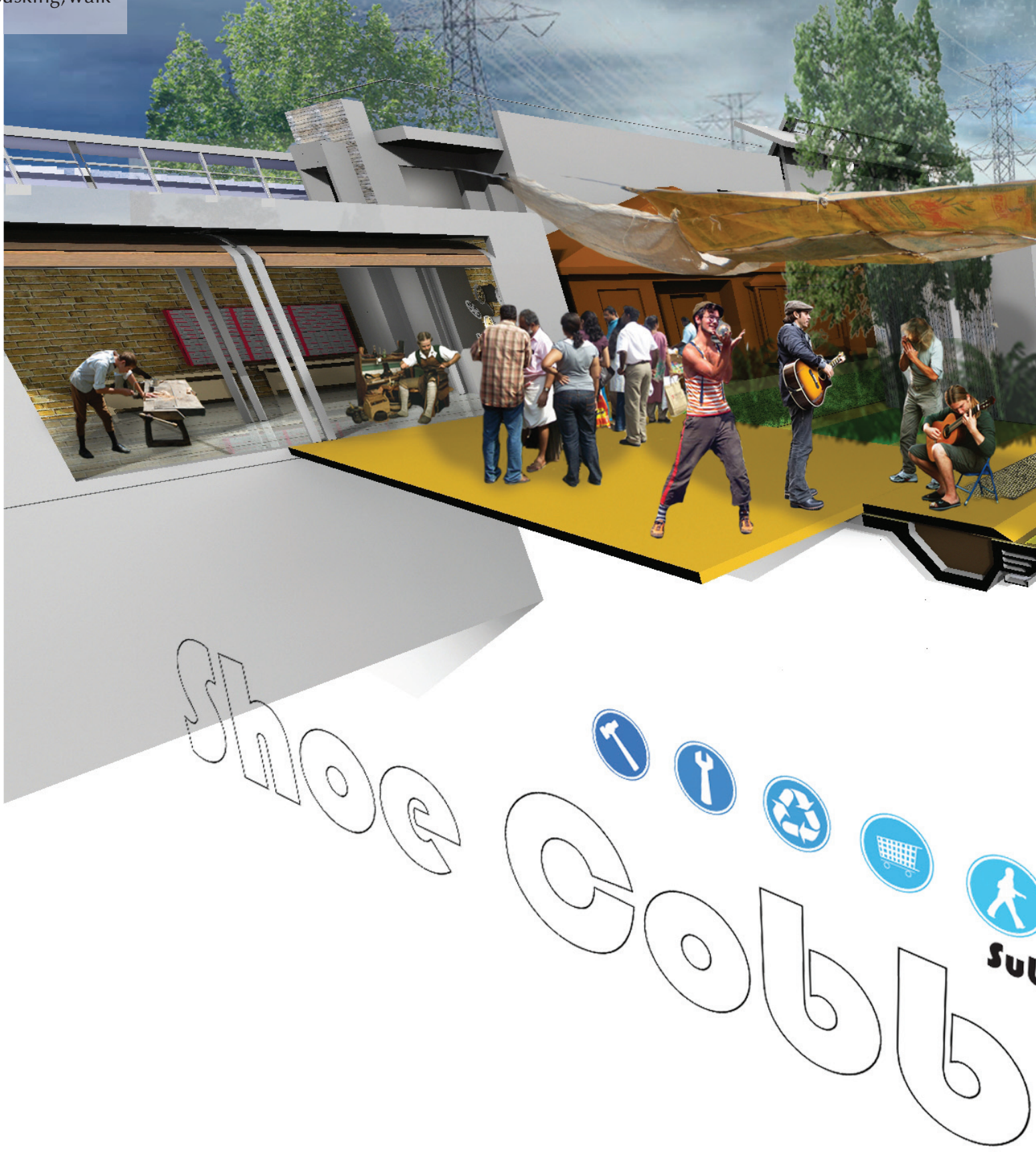




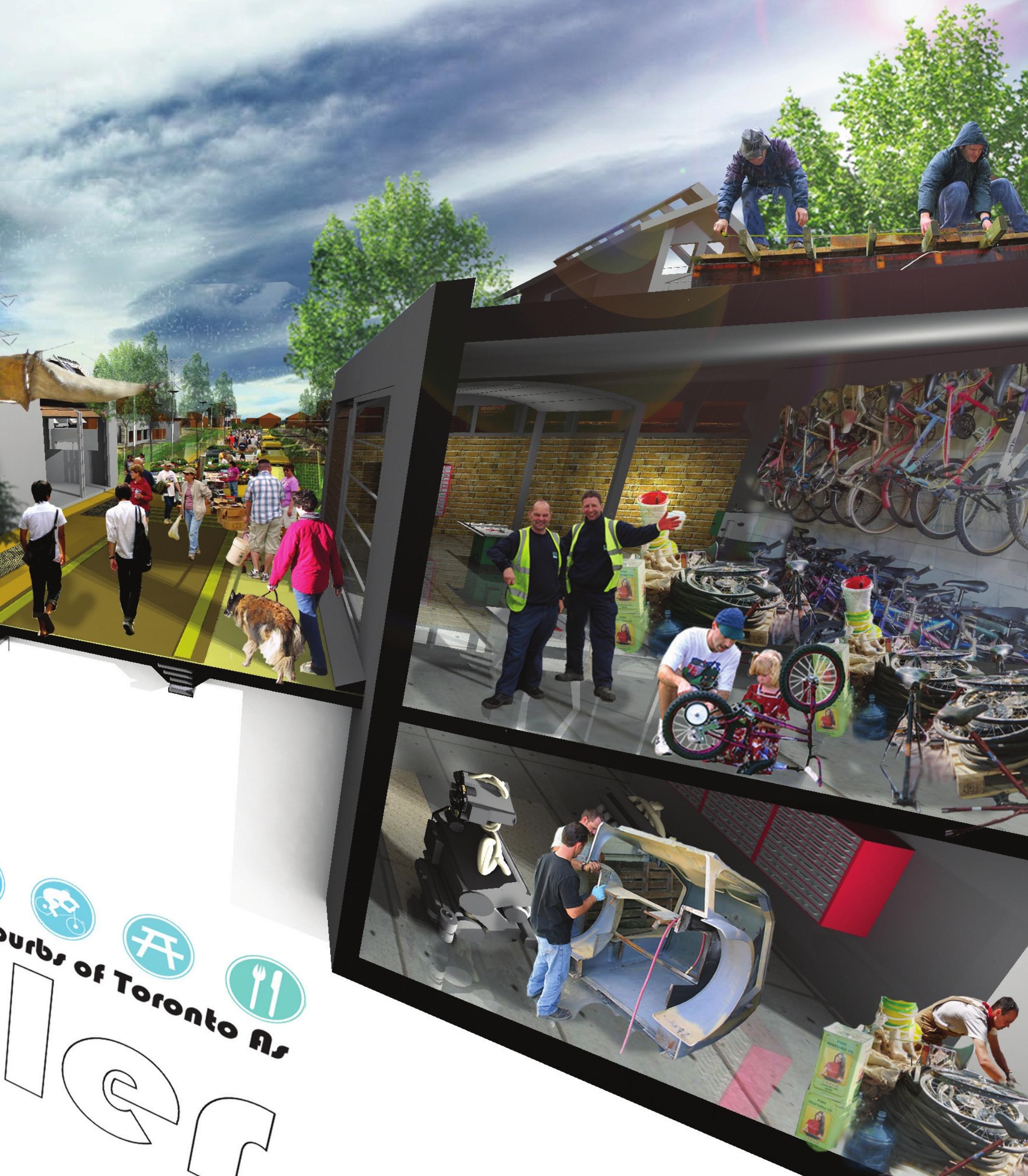


fig. 4.2.19 shoe cobbler located in Knob Hill it is proposed that shoe cobbler typologies (locations focusing on retail activities, repurposing of materials, repair shops, etc.) will be located in close proximity to arterials and major roads. In this way, the retail activities occuring in these typologies could act as extentions of the higher traffic retail activities occuring on the major arterials of the city.

\section{opposite}

fig. 4.2.20 Toronto transportation system shown is the major roads and arterials of Toronto and the GTA. Any shoe cobbler approach would need to connect to these transportation networks and be a part of the movement of goods throughout the city and region. Shoe cobbler typologies would also be located on and around such major arterials.

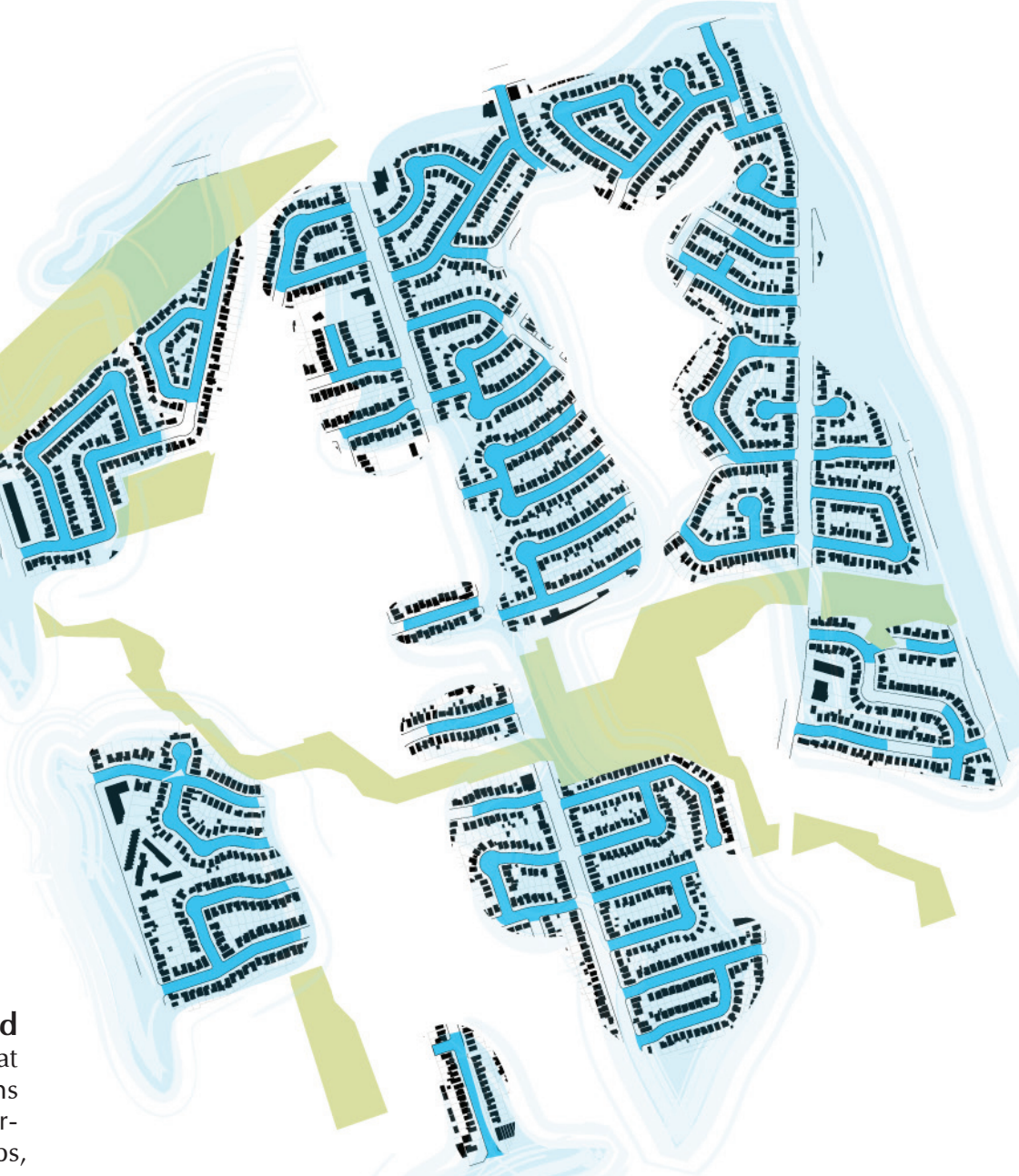



conclusion the modern city is vulnerable to failure, it is nonresilient to possible future crises such as peak oil, climate change, resource depletion and economic shocks due to dependencies on global economies and the drying-up of local markets. The modern city's largest housing sector, its suburban housing developments, are becoming obsolete in the face of such uncertainties. Mono-cultural, turn-of-the-century attitudes towards city building are preserving suburban developments in such vulnerable states and preventing them from transitioning into resilient, durable futures.

We need new visions for the repurposing of such obsolete housing developments, new modes of thinking based on resilience building, transitioning out of crises, and ecological systems thinking; modes of thinking based on responses to feedback loops, flexibility and the ability to adapt and change. The city needs to allow, in its form and character, the repurposing of its space and land in response to critical future uncertainties and projected failures due to future crises.

This thesis looks at a range of precedent studies to discover current approaches which respond to such critical issues, and to glean options which are available for the renewal of Toronto's suburban inheritance. Principles were gleaned from the study of such precedents and summarized as follows. Suburban Renewal will include:

Suburban Street - A connective street, a pedestrian corridor with portions suitable for appropriation and resident involvement, interaction and play 
Suburban Space - A physical redefinition that encourages interaction, activities, a sense of place, and a rich environment; a diversity of spatial arrangements woven into a connected fabric.

Suburban Change - A proposed process for changes to occur over time, organically and dispatched as residents, homeowners, and communities respond to future uncertainties.

From Mole Hill's reclaimed street approach, to Estudio Teddy Cruz's valuable lessons from Tijuana housing adaptations, there are tremendous opportunities for Toronto's suburbs to redefine themselves, to build resilience and to become a vital component of Toronto's durability.

This thesis proposes incremental, slow and gradual change; an accumulation of new buildings and new landscape programs that will progressively redefine the physical qualities of the suburban landscape. Renewal of Toronto's suburbs will not be in the form of a blank slate approach, but rather will arise from the intentional weaving of new functions and new developments within existing residential patterns, existing suburban qualities, and with the participation of existing neighbourhoods and communities.

This thesis proposes a redevelopment strategy which is applied to the suburban neighbourhood known as Knob Hill in East Toronto. It is a neighbourhood largely defined by its dependencies on the automobile, its inaccessibility for pedestrians, its lack of access to food, employment and other essential amenities. The intention of this thesis was not to impose a master plan for Knob Hill, but to create a framework for gradual and incremental changes to occur within the existing infrastructures, services, and property boundaries rather than erasing or replacing the existing neighbourhood. This new vision for the suburbs serves not to replace them with dense housing blocks, but to maintain and add to suburban qualities while also provoking new ideas for introducing resilience into our built environment. 
Policy models were explored, examining how such a framework for incremental change could be supported by municipal regulatory systems. The Development Permit System and the Cooperative Housing Model are two such policy models that would encourage resident participation in the reformation of their neighbourhoods. Despite the existence of such policy models, there still remain tremendous hurdles to overcome whenever deviating from current zoning and by-law ordinances. Can such ordinances be made to be more flexible, more responsive to processes and incremental renewal?

Further investigations in this field of study might include inquiries into the specific codes and bylaws preventing such proposed strategies from occurring; further study into the relationship of public to private space if such redevelopment strategies were employed; further study into the public perception of such strategies, namely which of the possible strategies would be more easily accepted and why; and how such strategies could find funding, support and advocacy in order to be realized.

With the proposed redevelopment strategy acting as a catalyst for change, this thesis proposes the creation of new neighbourhood typologies, typologies focused on responses to particular critical issues such as water, ecological, food, energy and material concerns. The thesis argues that, with the proposed redevelopment strategy, suburban Toronto will be able to act as the grounds for feedback loops; a responsive terrain for addressing future crises as they arise.

Although it is often argued that low density neighbourhoods, such as Toronto's suburbs, will be unsustainable in the face of unforeseeable crises, this thesis argues that Toronto's suburban inheritance is ideal for resilience building and will in fact be a vital aspect of Toronto's durability in the face of future uncertainties. 
bibliography Allenby, B., Fink, J. (2005). Toward inherently secure and resilient societies. Science. 309, p.1034.

Almy, D. (2007). On landscape urbanism. Austin, TX: Center for American Architecture and Design, University of Texas at Austin School of Architecture.

Anielski, M. (2009). Are we happy yet: All the money in the world won't buy it, so what are we working for?. Alternatives Journal. 25(6). p.13.

Architecture 2030 (2009). The 2030 Challenge. Architecture 2030. Retrieved on March 20,2009 from http://www.architecture2030.org/home.html Arcosanto, (2005). Arcosanto project history. Found on Arcosantos website. Retrieved on September 302009 from

http://www.arcosanti.org/project/background/history/ main.html

Ayers, J., Forsyth, T. (2009). Community-based adaptation to climate change: Strengthening resilience through development. Environment. 51 (4), p. 22.

Borden, G. (2007). Propositions for suburban living: Making the ordinary extraordinary. Journal of Architectural Education. Blackwell Publishing. p. 7683.

Carlisle, S., Hanlon, P. (2008). Well-being' as a focus for public health? A critique and defense. Critical Public Health.18 (3), p. 263.

Campbell, C. (June, 2009). Energy shock and oil myths. Macleans. (122) 21, p. 26.

CBC (2003). The great blackout 2003. Orginally broadcasted Broadcast Aug. 14, 2003. Retrieved on November 14 2009 from http://archives.cbc.ca/science technology/ energy production/clips/13545/

Chamberlin, S. (2009). The transition timeline for a local, resilient future. Foxhole, Devon: Green Books.

Chow, R. (2002). Suburban space: The fabric of dwelling. Berkeley: University of California Press.

City of Toronto Urban Development Services. (December 2003). Toronto Housing. Profile Toronto. No. 2. 
Corner, J. (1999). Recovering landscape: essays in contemporary landscape architecture. New York: Princeton Architectural Press.

Czech, B., Herman, D. (2004). In my opinion: The steady state economy — what it is, entails, and connotes. Wildlife Society Bulletin. 32(2), p.598.

Diamond, J. (2004). Collapse: How societies choose to fail or succeed. New York: Viking.

Dodman. D. (2009). Urban density and climate change. Prepared for the United Nations Population Fund (UNFPA). Retrieved on September 302009 from http://www.unfpa.org/webdav/site/global/users/schensul/ public/CCPD/papers/

Doron, G. (2005). Urban agriculture: Small, medium, large. Retrieved from Avery Index to Architectural Periodicals.

Drukker, C. (2006). Five steps towards a new suburbia: Economical, environmental, physical, social governmental. California: Planning Centre.

Duany Plater Zyberk \& Company. (2008). Suburban retrofit and infill: A lexicon of advanced techniques. Retrieved on September 282009 from http://www.transect. org/docs/SuburbanRetrofitBoards.pdf

Duerksen, C. (2008). Saving the world through zoning: The sustainable community development code comes to the rescue. American Planning Association. Retrieved on November 232009 from http://law.du.edu/documents/rmlui/saving-the-worldthrough-zoning.pdf

Dunster, B., Simmons, C., Gilbert, B.(2008). The ZEDbook: Solutions for a shrinking world. Abingdon, Oxon: Taylor \& Francis.

E.R.A Architects, University of Toronto. (2008). Mayor's tower renewal: Opportunities book. Prepared for the City of Toronto. City of Toronto. 
Farrell, J., Morris, D. (2009). Energy self-reliant states: Second and expanded edition. New Rules Project. Retrieved on November 12009 from http://www.newrules. org/sites/newrules.org/files/ESRS.pdf

Fenderson, A. (June, 2004). Peak oil and permaculture: David Holmgren on energy descent. Global Public Media. Retrieved on November 192009 from http://www. energybulletin.net/node/524

Florida, R., Gulden, T. (2005). The world in numbers: The world is spiky-Globalization has changed the economic playing field, but hasn't leveled it. The Atlantic Monthly. 296(3), p. 48.

Friedman, A. (2005). Room for thought: Rethinking home and community design. Toronto: Penguin Canada.

Friedman, A. (2002). Planning the new suburbia: Flexibility by design. Vancouver: UBC Press.

Friedman, T. (2005). The world is flat: A brief history of the twenty-first century. Farrar, Straus and Giroux

Fulton,G. (2005). Landscape Urbanism: A Manual for the Machinic Landscape Review. Landscape Journal. pp.4.

Girardet, H. (2004). Cities, people, planet: Liveable cites for a sustainable world. Chichester West Sussex: WileyAcademy.

Gonzalez-Nova, M., Murphy, C. (1999). Urban agriculture in the city of Havana: A popular response to a crisis. Growing Cities, Growing Food: Urban Agriculture on the Policy Agendas- A Reader on Urban Agriculture. Deutshe Stiftung fuer internationale Entwicklung, p.329.

Grant, L. (2007). Peak oil as a behavioral problem. Behavior and Social Issues. 16(1), p. 65.

Grdadolnik, H. (2005). Garden City: An Exemplary Housing Cooperative Take Heritage Preservation and Sustainability to a Meaningful New Level, Canadian Architect

Harris, R.(1996). Unplanned suburbs: Toronto's American tragedy 1900 to 1950. Baltimore: Johns Hopkins University Press. 
Haeg, F. (2008). Edible estates: Attack on the front lawn. New York: Metropolis Books.

Hen, P., Henning, J. (2002). Urban agriculture and sustainable urban systems: A benefits assessment of the garden movement in Havana, Cuba. Int. J. Environment and Sustainable Development. 1(3), p. 202-209.

Henstra, D. et al. (2004). Background paper on disaster resilient cities. Prepared by the Institute for Catastrophic Loss Reduction. Retrieved on November 28, 2009 from http://www.infc.gc.ca/research-recherche/resultsresultats/rs-rr/rs-rr-2004-03-eng.html

Holmgren, D. (2002). Permaculture: Principles and Pathways Beyond Sustainability. Sydney: Holmgren Design Services.

Holmgren, D. (2005). Retrofitting the suburbs for sustainability. Raise the Hammer. Retrieved on November 122009 from http://www.raisethehammer.org/index.asp?id=175

Homer-Dixon, T. (August 2009). The newest science: Replacing physics, ecology will be the master science of the $21^{\text {st }}$ century. Alternatives. 35(4), p.4.

Hopkins, R. (2008). The transition handbook: From oil dependency to local resilience. Foxhole, Devon: Green Books.

Ingersoll, R. (2006). Sprawltown: Looking for the city on its edges. New York: Princeton Architectural Press.

Jacobs, J. (1961). The Death and Life of Great American Cities. New York: Vintage Books.

Kenworthy, J. (2007). Urban planning and transport paradigm shifts for cities of the post-petroleum age. Journal of Urban Technology, 14(2), p. 47.

Kunstler, J. (2005). The long emergency: Surviving the end of oil, climate change, and other. New York. Grove Press. 
Lamphier, G. (2009). NIMBY neighbors air urban sprawl:

Small builder faces costly opposition to putting tidy duplexes in place of derelict bungalows. Emotional Journal. Retrieved on November 112009 from http://www.edmontonjournal.com/story print. $\underline{\mathrm{htm} l}$ ?id=1895915\&sponsor $=$

Leach, B. (2008). Home Renovation Mortgages: A Growing Component of Canadian Mortgages, Ezine Articles Leanard, A. (2007). The Story of Stuff. Released December 4, 2007. Directed by Louis Fox. Free Range Studios.

Learch, D. (2007). Post carbon cities: Planning for energy and climate uncertainty. Sebastopol California: Post Carbon Institute.

McDonough, W., Braungart, M. (2002). Cradle to cradle: Remaking the way we make things. New York: North Point Press.

McCartney, G., Hanlon, P. (2008). C Climate change and rising energy costs: A threat but also an opportunity for a healthier future? Public Health. 122, p. 653

McHarg, I. (1969). Design with nature. Garden City, N.Y.: the Natural History Press.

McKibben, B. (2007). Deep economy: The wealth of communities and the durable future. New York: Henry Holt.

Mackenzie, K. (2009). The real question about peak oil. Financial Times. Aug 7,2009. p. 8.

Mazria, E. (2009). The 2030 Challenge Stimulus Plan, Architecture 2030 Inc.

Mostafavi,M. et al. (2003). Landscape urbanism: a manual for the machinic landscape. London: Architectural Association.

Murphy, P. (2008). Plan C: Community survival strategies for peak oil and climate change. Gabriola Island, BC: New Society Publishers.

Newman, P. (2007). Beyond peak oil: Will our cities collapse? Journal of Urban Technology. Routledge. 
OMMAH, Ontario Ministry of Municipal Affairs and Housing (2008). Development Permit System: A Handbook for Municipal Implementation, Provincial Planning Policy Branch

OToole, R. (2001). The Folly of "Smart Growth": Oregon's experience suggests "anti-sprawl" strategies worsen the problems they are intended to solve. Regulation. Retrieved on September 122009 from http://www.cato.org/pubs/regulation/regv24n3/otoole.pdf

Ouroussoff, N. (2008). Learning From Tijuana: Hudson, N.Y., Considers Different Housing Model, New York Times

Panayotova, T. (2002). Ecology of the Street, Journal of Undergraduate Research, University of Florida

Pena Diaz, J., Harris, P. (2005). Urban agriculture in Havana: Opportunities for the future. Found in CPULs: Continuous Productive Urban Landscape. Ed. by Andre Viljoen, Katrin Bohn and Joe Howe. Amsterdam: Elsevier,p. 135.

Permaculture Drylands Institute. (Autumn,1989 Published in The Permaculture Activist Retrieved on November $18^{\text {th }}, 2009$ from www.permacultureactivist.net

Peterson, G. (2006). Teddy Cruz: What Adaptive Architecture can learn from Shantytowns, Resilience Science

Potter, A. (June 2009). Peak water, peak fish and the end of everything. Macleans. 122,(24) p.15.

RBC (2008). RBC Finds Canadian Homeowners Turn to EcoFriendly Renovations to Save Money, Canada News Wire

Reburbia. (2009). Reburbia: A suburban design competition. Retrieved on September 15,2009, from http://www.re-burbia.com

Roseland, M. (1997). Eco-city: Healthy communities healthy planet. Gabriola Island, BC: New Society Publishers.

Ruby, I. Ruby, A. (July/August 2004). The challenge of suburbia. Architectural Design. 74(4) Wiley-Academy. 
Sewell, J. (2009). The shape of the suburbs: Understanding Toronto's sprawl. Toronto: University of Toronto Press.

Schepel, S. (2005). Woonerf Revisited: Delft as an example, Childstreet 2005

Shane, G. (2004). The emergence of landscape urbanism: Reflections on Stalking Detroit. Harvard Design Magazine. (19), pp.1.

Shuman, M. (1998). Going local: Creating self-reliant communities in a global age. New York: Free Press.

Tanzer, K. et al. (2007). The Green Braid: Towards an Architecture of Ecology, Economy, and Equity, Association of Collegiate Schools of Architecture, Taylor \& Francis Inc.

Timmer, V., Seymoar N. (2005). Vancouver working group discussion paper: The livable city. International Centre for Sustainable Cities. Presented at the World Urban Forum 2006. Retrieved on November 62009 from http://www.ahva.ubc.ca/WUF/pdf/e the livable city eng.pdf

Tobin, S. (2008). Garages aren't just for cars anymore: One way to retrofit suburbs for a post carbon world. American Planning Association. Retrieved on November 1,2009 from http://www.planning.org/planning/2008/dec/ garages.htm

Tyndorf, T. (2002). Toronto Official Plan. Toronto City Planning. Retrieved on September23 2009 from http://www.toronto.ca/torontoplan/

Unesco (2010). Co-operative Housing in Canada: A Model for Empowered Communities. Management of Social Transformations. Retrieved July 20,2010 from http:// www.unesco.org/most/usa3.htm

Vermeulen, S. (2006). An architecture of daily life: Thesis project. University of Waterloo.

Viljoen et al. (2005). CPULS: Continuous productive urban landscapes. Oxford: Elsevier.

Waldheim ,C. (2006). Landscape urbanism reader. New York: Princeton Architectural Press. 
Walter-Toews,D., Kay, J., Lister, N. (2008). The ecosystem approach:

Complexity, uncertainty, and managing for sustainability. New York: Columbia University Press

Wilkinson, P. (2008). Peak oil: Threat, opportunity or phantom? Public Health.122, p. 664.

Wilcox A., et al. (2007). Greentopia: Towards a sustainable Toronto. Toronto: Coach House Books. 
